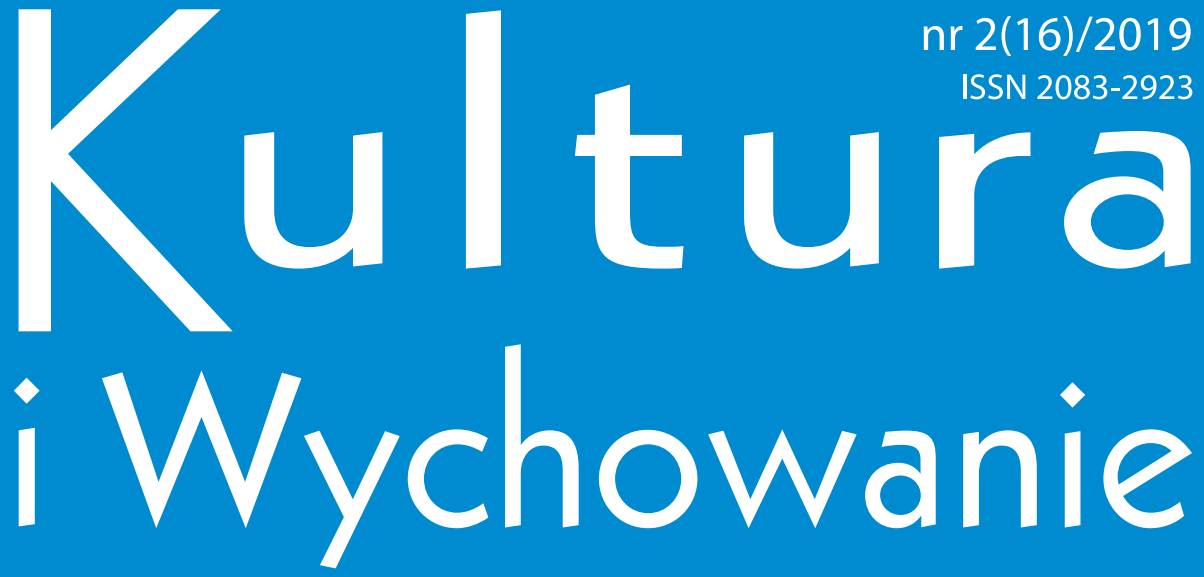

Półrocznik pedagogiczny 


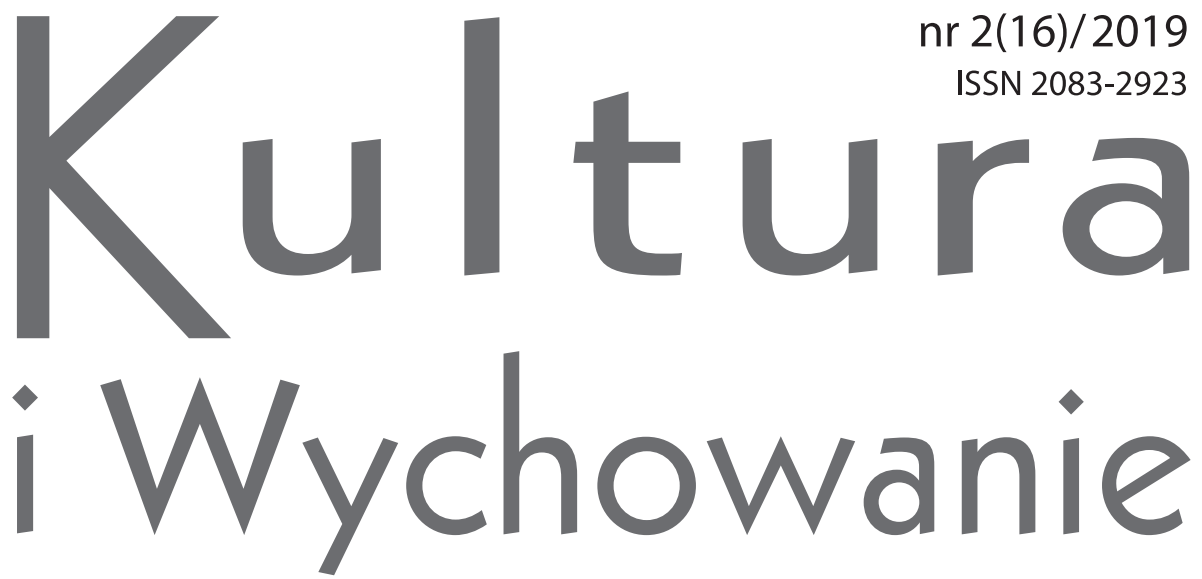

Półrocznik pedagogiczny 
REDAKCJA CZASOPISMA

Redaktor naczelny: dr Krzysztof Kamiński

Z-ca redaktora naczelnego: dr Elżbieta Woźnicka

Sekretarz redakcji: dr Agata Andrzejewska

\section{RADA NAUKOWA}

\section{Przewodnicząca rady naukowej}

dr hab. Zofia Szarota, prof. UW, Uniwersytet Warszawski

\section{Polska rada naukowa}

prof. dr hab. Irena Adamek, Akademia Techniczno-Humanistyczna w Bielsku-Białej prof. dr hab. Edyta Gruszczyk-Kolczyńska, Akademia Pedagogiki Specjalnej im. Marii Grzegorzewskiej w Warszawie prof. dr hab. Bożena Muchacka, Uniwersytet Pedagogiczny im. KEN w Krakowie prof. dr hab. Maria Szyszkowska, Uniwersytet Warszawski, Komitet Prognoz „Polska 2000 Plus" przy Prezydium PAN prof. dr hab. Stanisław Gałkowski, Akademia Ignatianum w Krakowie dr hab. Rafał Godoń, Uniwersytet Warszawski prof. dr hab. Krzysztof Jakubiak, Uniwersytet Gdański prof. dr hab. Lech Mokrzecki, emerytowany prof. UG, Uniwersytet Gdański prof. dr hab. Stanisław Palka, Uniwersytet Jagielloński w Krakowie dr hab. Dariusz Stępkowski, prof. UKSW, Uniwersytet Kardynała Stefana Wyszyńskiego w Warszawie prof. dr hab. Bogdan Szczepankowski, Społeczna Akademia Nauk w Warszawie dr hab. Sławomir Szczyrba, Uniwersytet Kardynała Stefana Wyszyńskiego w Warszawie (WSD w Łodzi)

dr hab. Sławomir Sztobryn, prof. ATH, Akademia Techniczno-Humanistyczna w Bielsku-Białej

\section{Międzynarodowa rada naukowa}

prof. dr hab. Blanka Kudláčová, Uniwersytet w Trnavski w Trnavie, Słowacja prof. dr hab. Naděžda Pelcová, Uniwersytet Karola w Pradze, Czechy prof. dr hab. Irina Predborska, Towarzystwo Filozofii Edukacji, Ukraina prof. dr hab. Ałła Wasyluk, Narodowa Akademia Nauk Pedagogicznych Ukrainy, Ukraina prof. dr hab. Dietrich Benner, Uniwersytet Berliński, Niemcy prof. dr hab. Rudolf Dupkala, Uniwersytet Preszowski w Preszowie, Słowacja 
RECENZENCI „Kultura i Wychowanie” nr 2(16)/2019

dr hab. Jakub Bartoszewski, prof. PWSZ, Państwowa Wyższa Szkoła Zawodowa w Koninie dr hab. Helena Marzec, prof. AHE, Akademia Humanistyczno-Ekonomiczna w Łodzi dr hab. Dorota Podgórska-Jachnik, prof. UŁ, Uniwersytet Łódzki dr hab. Renata Szczepanik, prof. UŁ, Uniwersytet Łódzki dr hab. Sławomir Sztobryn, prof. ATH, Akademia Techniczno-Humanistyczna w Bielsku-Białej

dr Andrzej Zbonikowski, Akademia Humanistyczno-Ekonomiczna w Łodzi dr Anna Lubrańska, Uniwersytet Łódzki dr Renata Góralska, Uniwersytet Łódzki prof. dr hab. Joanna Madalińska-Michalak, Uniwersytet Warszawski dr Joanna Swędrak-Zawada, Wyższa Szkoła Bankowa w Opolu dr hab. Elżbieta Dul-Ledwosińska, prof. AHE, Akademia Humanistyczno-Ekonomiczna w Łodzi

dr Zofia Okraj, Uniwersytet Jana Kochanowskiego w Kielcach dr hab. Rafał Godoń, prof. UW, Uniwersytet Warszawski

\section{Redakcja czasopisma „Kultura i Wychowanie”}

Akademia Humanistyczno-Ekonomiczna w Łodzi

90-212 Łódź, ul. Sterlinga 26

e-mail: kulturaiwychowanie@ahe.lodz.pl

strona www: www.pedagogika.pl

Ten utwór jest dostępny na licencji Creative Commons Uznanie autorstwa-Na tych samych warunkach 4.0 Międzynarodowe.

$$
\text { (c) (1) () () }
$$


(C) Copyright by Akademia Humanistyczno-Ekonomiczna w Łodzi Łódź 2019

ISSN 2083-2923

Wersją podstawową jest wersja elektroniczna

Projekt graficzny okładki

Joanna Niekraszewicz

Redaktor prowadzący

Iwona Morawska

Redakcja językowa i korekta

Iwona Cłapińska (j. polski)

Ph. D. Michael Fleming (j. angielski)

Opracowanie typograficzne i skład DTP

Monika Poradecka

\section{Wydawnictwo}

Akademii Humanistyczno-Ekonomicznej w Lodzi

90-212 Łódź, ul. Sterlinga 26

tel. 426315908

wydawnictwo@ahe.lodz.pl

www.wydawnictwo.ahe.lodz.pl 


\section{Spis treści}

\section{ARTYKUKY NAUKOWE}

Katarzyna Błachnio

Planowanie kariery zawodowej - przegląd wybranych form

wsparcia.....

Natalia Mandecka

Wypalenie rodzicielskie - nowe spojrzenie na przemęczonych

rodziców. Przegląd literatury oraz badań ..

Agnieszka Deja

Działania podopiecznych destabilizujące relacje $w$ rodzinnym domu dziecka

Dorota Pufund

„Zrozumieć niepojęte” - specyfika odbioru i przetwarzania bodźców sensorycznych u dzieci ze spektrum autyzmu .

\section{Zuzana Lopatková}

Love in parenting, upbringing and education of the infants

(Contribution to the history of institutional pre-school education

in the 19th century using the example of Trnava town).

Ivan Podmanický

Pedagogical love and prosociality in school education in Slovakia ..

Andrej Rajský

Love as absolute challenge - also for education

Marek Wiesenganger

Is it possible and necessary to cultivate love? Education to love according to "Summa Theologiae" of Thomas Aquinas 
Yevgen Volodymyrovych Kulyk, Yuriy Kulyk

The problems of humanising technological education

Anna Sarbiewska

Visible Learning and educational policies in New Zealand

and Australia

Dace Silina, Kamila Witerska

How to make a step towards future education. Teaching/learning methods in higher education for the 21 st century

\section{SPRAWOZDANIA I RECENZJE}

Dariusz Stępkowski

Recenzja książki: Tomasz Leś, Koncepcje mądrości w filozofii Sokratesa,

Platona i Arystotelesa, Wydawnictwo Uniwersytetu Jagiellońskiego,

Kraków 2016, 168 ss

\section{STUDENCI PISZA}

Kamil Lewandowski

Zajęcia taneczne z młodzieżą z niepełnosprawnością intelektualną jako forma terapii pedagogicznej 


\section{Contents}

\section{ACADEMIC ARTICLES}

Katarzyna Błachnio

Career planning - an overview of selected forms of support

Natalia Mandecka

Parental Burnout - a new look at the 'exhausted parent' -

A review of the literature badań.

Agnieszka Deja

Actions of foster children destabilising relationships

in the family foster home.

Dorota Pufund

"Understanding the inconceivable" - The reception and processing

of sensory stimuli in children with autism spectrum disorder

\section{Zuzana Lopatková}

Love in parenting, upbringing and education of the infants

(Contribution to the history of institutional pre-school education

in the 19th century using the example of Trnava town)

Ivan Podmanický

Pedagogical love and prosociality in school education in Slovakia .......

Andrej Rajský

Love as absolute challenge - also for education

Marek Wiesenganger

Is it possible and necessary to cultivate love? Education to love

according to "Summa Theologiae" of Thomas Aquinas

Yevgen Volodymyrovych Kulyk, Yuriy Kulyk

The problems of humanising technological education 


\section{Anna Sarbiewska}

Visible Learning and educational policies in New Zealand and Australia.

Dace Siliṇa, Kamila Witerska

How to make a step towards future education. Teaching/learning methods in higher education for the 21 st century

\section{REPORTS AND REVIEWS}

Dariusz Stępkowski

The review of the book: Tomasz Leś, Koncepcje mądrości

w filozofii Sokratesa, Platona i Arystotelesa [Concepts

of wisdom in the philosophy of Socrates, Plato and Aristotle],

Wydawnictwo Uniwersytetu Jagiellońskiego, Kraków 2016,

168 pages

\section{STUDENTS WRITE}

Kamil Lewandowski

Dance classes with teenagers with intellectual disabilities, as a form of pedagogical therapy 


\title{
Planowanie kariery zawodowej - przegląd wybranych form wsparcia
}

https://doi.org/10.25312/2083-2923.16/2019_01kb

\begin{abstract}
Streszczenie: Celem artykułu jest analiza procesu planowania kariery zawodowej oraz przegląd wybranych form wsparcia. Jest on swoistą próbą odpowiedzi na pytanie, jak świadomie kształtować własną drogę zawodową. Wybierając odpowiednie strategie planowania własnej kariery, trzeba wziąć pod uwagę wiele różnych aspektów. Tworzenie indywidualnej ścieżki rozwoju zawodowego wiąże się z umiejętnościami, zdolnościami, kwalifikacjami, cechami osobowości. Nade wszystko podstawową zasadą planowania rozwoju zawodowego jest znajomość swoich możliwości i ograniczeń, by móc doskonalić się, nadając karierze kierunek. Artykuł zawiera przegląd działań realizowanych w ramach poradnictwa zawodowego, kierowanych zarówno do młodzieży, jak i osób dorosłych.

Słowa kluczowe: kariera, rozwój, poradnictwo, doradztwo zawodowe
\end{abstract}

\section{Wprowadzenie}

Posiadamy wrodzone pragnienie,

by nieustannie uczyć się, wzrastać i rozwijać.

Chcemy stać się czymś więcej, niż jesteśmy.

Chuck Gallozzi

W dzisiejszym zmieniającym się świecie, w którym idea całożyciowego uczenia się (long-life-learning) staje się koniecznością, jednym z najważniejszych wyzwań ży-

* Katarzyna Błachnio - mgr, doktorantka Akademii Pedagogiki Specjalnej im. Marii Grzegorzewskiej w Warszawie na kierunku pedagogika. W ramach rozprawy doktorskiej prowadzi badania naukowe dotyczące problematyki współczesnego ojcostwa. Swoje zainteresowania naukowe koncentruje wokół nauk społecznych. 
ciowych jest samodzielne konstruowanie własnej kariery ${ }^{1}$. Podczas gdy cele i plany ulegają ciągłym zmianom, pojawia się potrzeba rozwijania kompetencji oraz podnoszenia własnych kwalifikacji w sferze edukacji i pracy. Stanowią one dla wszystkich, a zwłaszcza dla młodzieży, szczególne wyzwanie. Niewiele osób jest przygotowanych na podejmowanie decyzji w kwestii planowania własnej kariery. $\mathrm{W}$ tej sytuacji niezwykle ważną rolę odgrywają rodzice, nauczyciele, ale też doradcy. Wsparcie młodzieży i osób dorosłych w planowaniu ścieżki kariery to zatem główne zadanie współczesnego poradnictwa.

Czym więc jest kariera i rozwój zawodowy? Pojęcie kariery zawodowej ma istotne znaczenie w życiu każdego człowieka. Subiektywne odczucia wiążą się z poziomem aspiracji i oczekiwań danej jednostki - to, co dla jednego jest karierą, dla innego może być jedynie niewielkim wyróżnieniem ${ }^{2}$. Niemniej jednak jest to proces uczenia się i doskonalenia przez całe życie. Dotyczy pogłębiania wiedzy i poszukiwania wciąż nowych metod i dróg rozwoju. „Uczenie się jest zawsze powiązane z czymś nowym i motywuje ludzi - bez względu na wiek - do zaangażowania się w rozwój w każdym momencie życia"’.

W literaturze przedstawiane są liczne definicje pojęcia kariera. Według Alicji Kargulowej na karierę zawodową składają się pewne wydarzenia życiowe. To sekwencja wykonywanych zawodów i danych ról życiowych. Razem wyrażają stosunek do pracy w aspekcie całkowitego procesu rozwoju osobowości ${ }^{4}$. Kariera zawodowa wiąże się ściśle z poradnictwem zawodowym. D. Brown i L. Brooks określają ją jako proces interpersonalny, którego celem jest towarzyszenie w sytuacji rozwoju kariery. Rozwój jest rozumiany jako proces wyboru i przystosowania do zawodu. Trwa przez całe życie i pozostaje $\mathrm{w}$ interakcji $\mathrm{z}$ innymi rolami człowieka ${ }^{5}$. Następuje $\mathrm{w}$ ciągu całego życia, a odzwierciedleniem rozwoju jest kariera życiowa i zawodowa.

W obliczu pojawiających się trudności na rynku pracy kluczowe stają się umiejętności: podejmowania decyzji zawodowych, przystosowania do nowych wyzwań oraz podnoszenia własnych kwalifikacji. Drogą do ich nabycia jest ciągłe doskonalenie poprzez samopoznanie. Samoocena własnych możliwości, zdolności, zainteresowań oraz cech osobowości jest niezbędna podczas konfrontacji z wymaganiami zawodowymi i sytuacją na rynku pracy. Osoby wkraczające na rynek pracy lub dokonujące próby utrzymania się na nim często potrzebują wskazówek, jak radzić sobie w konkretnych warunkach. Tym bardziej że problemy związane z podejmowaniem decyzji zawodowych we współczesnym społeczeństwie mają specyficzny charakter. Dlatego

${ }^{1} \mathrm{~J}$. Minta, Od autora do autora. Wspieranie młodzieży w konstruowaniu własnej kariery, KOWEZiU, Warszawa 2012, s. 6.

${ }^{2}$ J. Wasilewski, Kariery społeczno-zawodowe dyrektorów, Zakład Narodowy im. Ossolińskich Ossolineum, Wrocław 1981, s. 104.

${ }^{3}$ S.M. Kwiatkowski, J. Madalińska-Michalak, Przywództwo edukacyjne, współczesne wyzwania, Wolters Kluwer, Warszawa 2014, s. 17-18.

4 A. Kargulowa, O teorii i praktyce poradnictwa, PWN, Warszawa 2005, s. 21.

${ }^{5}$ K. Lelińska, Zawodoznawstwo w planowaniu kariery, OHP, Warszawa 2006, s. 14. 
problemy poruszane w artykule dotyczą sposobów wsparcia procesu rozwoju zawodowego.

W praktycznym aspekcie takie wsparcie można uzyskać poprzez profesjonalną pomoc doradczą. Stwarza ona możliwości zdobywania i rozwijania umiejętności potrzebnych w celu planowania kariery zawodowej. Oznacza to przygotowanie jednostki do ponoszenia odpowiedzialności za własne, świadome i przemyślane decyzje życiowe i zawodowe. Taką rolę wypełnia między innymi poradnictwo zawodowe, które jest szansą dla osób mających rozterki lub wątpliwości bądź też znajdujących się w sytuacji kryzysowej.

\title{
Poradnictwo zawodowe jako forma wsparcia rozwoju zawodowego
}

\author{
Trudności to okazja do tego, \\ by poprawiać i ulepszać, \\ to szczeble do świetniejszego doświadczenia. \\ Gdy jedne drzwi się zamykaja, inne zawsze stoja \\ otworem, \\ by utrzymać naturalny stan równowagi.
}

Brian Adams

W początkach poradnictwa w Polsce i na świecie jako pierwsze dominowało poradnictwo zawodowe, które skierowane było do konkretnej grupy wiekowej - głównie młodzieży. Z upływem czasu zaczęło rozwijać się i obecnie przyjęło formę poradnictwa kariery. Dotychczas jednostka podejmowała jednorazową decyzję co do wyboru przyszłego zawodu, lecz obecnie utrzymuje się tendencja dokonywania wielu wyborów zawodowych na przestrzeni całego życia. Wiąże się to z przekwalifikowaniem i nabywaniem nowych kompetencji. Jest to długi proces, podróż po wiedzę - ma wiele dróg, barier, ale też możliwości.

W filozoficznym ujęciu działalność poradnictwa jest określana jako „wszechstronne zajęcie - doradztwo jest zagmatwaną zagadką, gdzie tory rozumu łączą w sobie nieudolną szarpaninę z precyzją, by wydrzeć z nonsensu, mozolny proces, jak wiązanie fragmentów składanki, aż powstanie obraz" ${ }^{6}$. W tym ujęciu działalność poradnictwa nie jest jednorazowym aktem, lecz wymagającym procesem. Trwa długi czas. Polega na poszukiwaniu rozwiązań. Ostatecznie ma ułatwić dokonanie wyborów, jednocześnie ucząc świadomego kierowania własną przyszłością.

Praktyczny wymiar doradztwa zawodowego odzwierciedla sytuacja, w której „doradca pomaga jednostce w osiągnięciu lepszego zrozumienia siebie samego w odniesieniu do środowiska pracy, aby umożliwić mu realistyczny wybór/zmianę

\footnotetext{
${ }^{6}$ S.T. Gladding, Poradnictwo zawodowe - zajęcie wszechstronne, „Elipsa”, Warszawa 1994, s. 10.
} 
zatrudnienia lub też osiągnięcie właściwego przystosowania zawodowego"’. W myśl tej interpretacji doradztwo zawodowe skupia działania na rozwoju jednostki aż po dorosłość. Momentem przełomowym rozwoju staje się wybór zawodu, czyli szerszy wymiar przypisywany jest doradztwu kariery. Doradztwo kariery koncentruje się na całożyciowym rozwoju, ale także na pomaganiu człowiekowi w rozwiązywaniu problemów osobowości na różnych etapach życia ${ }^{8}$.

Porównując powyższą charakterystykę pojęć, można swobodnie określić cel poradnictwa zawodowego. Niezależnie od wieku i w każdym momencie życia celem staje się udzielanie pomocy danej jednostce. Owa pomoc dotyczy projektowania ścieżki kariery życiowo-zawodowej poprzez podejmowanie wielu decyzji na przestrzeni całego życia. Zadania, jakie należy wykonać, aby zamierzony cel został zrealizowany, to między innymi: pomaganie jednostce w poznaniu samej siebie oraz własnego potencjału, tak aby osiągnęła poziom akceptacji i stała się efektywna w działaniu; wskazanie możliwości rozwoju, które zaspokoją potrzeby i aspiracje jednostki; pomoc w odnalezieniu swoich wartości, postaw, zainteresowań, czyli poznaniu własnej osobowości; wyposażenie w konkretne umiejętności w zakresie podejmowania decyzji, planowania oraz wyznaczania celów życiowych i zawodowych; wspieranie w podjęciu i utrzymaniu zatrudnienia.

Jak widać, wymienione cele i zadania poradnictwa są ściśle ze sobą powiązane i przede wszystkim ukierunkowane na ukształtowanie aktywnej, odpowiedzialnej postawy wobec życia. Taka postawa przejawiać się ma poprzez samorealizację i samorozwój osoby.

Proces rozwoju powinien wspierać interdyscyplinarny zespół odpowiednio przygotowanych specjalistów. Możemy zaliczyć do nich: psychologa, nauczyciela, lekarza, lecz jedną z ważniejszych ról może odgrywać doradca zawodowy. Jego zadaniem jest pomaganie potrzebującym i motywowanie do samodzielnego działania. Ma być profesjonalistą pełniącym funkcję osoby doradzającej innym. To osoba udzielająca wskazówek, instrukcji, porad. Świadczy pomoc w wyborze odpowiedniego zawodu, miejsca zatrudnienia osobom bezrobotnym oraz innym poszukującym pracy. Doradca zawodowy uczestniczy w drodze do wzrostu świadomości i samorealizacji jednostki, co umożliwia dokonywanie wielu realistycznych wyborów, zmianę zatrudnienia, czy też osiągnięcia właściwego dostosowania społecznego ${ }^{9}$. Jego rola nie powinna ograniczać się tylko do pomocy dotyczącej wyborów zawodowych.

Dzisiejszy świat stawia przed nami wiele wyzwań, a zarazem trudności. Doradca jako profesjonalista mierzy się z problemami, rozterkami i bezsilnością swoich podopiecznych. Obecnie relacja doradcy z uczestnikiem często postrzegana jest jako działanie terapeutyczne. Z jednej strony „radzący się oczekuje eksperta, który wie, co dobre

${ }^{7}$ R. Lamb, Poradnictwo zawodowe w zarysie, Krajowy Urząd Pracy, Warszawa 1998, s. 8.

${ }^{8}$ C. Pielok, Poradnictwo zawodowe od początku - co to jest, dla kogo, po co?, [w:] Kwartalnik doradca zawodowy, Ecorys Polska, Warszawa 2009, s. 28.

9 D. Kulka, Ł. Bednarczyk, Poradnictwo zawodowe dla osób z grupy szczególnego ryzyka, Difin, Warszawa 2010, s. 12. 
i pożądane, i może dać szybko gotowe rozwiązanie. Innymi słowy, dokonuje wyboru za jednostkę, biorąc całkowitą odpowiedzialność za udzielone porady. [z drugiej strony] klienci poszukują też doradcy terapeuty, który wyciszy ich lęki, naprawi nadwątlone więzy"10. Życie w ciągłym stresie i napięciu, pogoń za pieniądzem, brak pewności siebie powodują, że ludzie szukają wsparcia, zrozumienia i wczucia się w sytuację osoby radzącej się. Współcześnie warto zadać pytanie, czy ważniejsze staje się rozwiązywanie konkretnych problemów zawodowych, czy wyposażenie osób w konkretne umiejętności radzenia sobie z otaczającą rzeczywistością. Coraz ważniejszymi elementami w poradnictwie zawodowym stają się metody radzenia sobie ze stresem, rozumienia świata, dbania o rozwój osobisty i zawodowy. Istotne w procesie poradnictwa są potrzeby, zainteresowania, dążenia, możliwości i ograniczenia, cechy osobowości jednostki, ale równie ważna jest zewnętrzna sytuacja. Na taką sytuację składają się: rynek pracy, wymagania zawodu i środowiska zawodowego, prawo pracy, środowisko pracy, przyszłość zawodu ${ }^{11}$.

Podstawowym aktem prawnym, na podstawie którego pracuje doradca zawodowy, jest ustawa o promocji zatrudnienia i instytucjach rynku pracy ${ }^{12}$. Artykuł 38 tej ustawy mówi, że poradnictwo zawodowe i informacja zawodowa polegają na udzielaniu osobom bezrobotnym i poszukującym pracy pomocy w wyborze odpowiedniego zawodu i miejsca zatrudnienia, a w szczególności na:

- udzielaniu informacji o świecie zawodów, rynku pracy i możliwościach kształcenia,

- udzielaniu porad z wykorzystaniem standaryzowanych metod ułatwiających wybór zawodu, zmianę kwalifikacji, podjęcie lub zmianę zatrudnienia, w tym badanie zainteresowań i uzdolnień,

- kierowaniu na specjalistyczne badania psychologiczne i lekarskie, umożliwiające wydawanie opinii o przydatności zawodowej do pracy i zawodu albo kierunku kształcenia,

- inicjowaniu, organizowaniu i prowadzeniu grupowych porad zawodowych dla bezrobotnych i poszukujących pracy.

Wiele osób nie potrafi właściwie zaplanować kariery zawodowej. Problem dotyczy w szczególności młodzieży, która nie jest odpowiednio przygotowana do wejścia na rynek pracy. Dlatego tak dużą rolę odgrywa właśnie poradnictwo zawodowe. Z praktyki wynika, że do odbiorców poradnictwa zawodowego należą osoby napotykające wiele problemów związanych z podjęciem decyzji zawodowej. Konieczność zmian w życiu zawodowym powoduje, że ludzie potrzebują pomocy i wsparcia.

Doradca zawodowy jako osoba prowadząca proces poradnictwa zawodowego jest odpowiedzialna za proces planowania ukierunkowany właśnie na osiągnięcie zado-

${ }^{10}$ B. Wojtasik, Podstawy poradnictwa kariery, KOWEZiU, Warszawa 2011, s. 110-111.

${ }^{11}$ M. Janas, Poradnictwo grupowe, [w:] J. Fundowicz, I. Cholewa (red.), Zeszyty informacyjno-metodyczne doradcy zawodowego, Urząd Pracy, Warszawa 1994, s. 61-62.

${ }_{12}$ Ustawa z dnia 20 kwietnia 2004 r. o promocji zatrudnienia i instytucjach rynku pracy, Dz.U. 2004, nr 99, poz. 1001. 
wolenia z pracy zawodowej. Jednym ze sposobów planowania, jaki może zaproponować osobie radzącej się, jest pomoc w wyznaczaniu celów. Oczywiste staje się, że

są to nie tylko cele zawodowe, ale i życiowe. Żyjąc według własnych prawd, mamy motywację i chęć rozwoju, co ma odzwierciedlenie w podejmowanej pracy. Dlatego praca zawodowa i aktywność pozazawodowa powinny się uzupełniać ${ }^{13}$.

Zasadniczo na planowanie składają się dwie czynności, tj. wyznaczanie celów do osiągnięcia oraz określanie zadań, jakie prowadzą nas do realizacji celu. To nic innego jak ustalenie wizji własnego życia. Wizja konkretnego celu, tego, co chcemy osiągnąć, to pierwszy krok dobrego planowania. Aby wyznaczyć cele, dana osoba musi zebrać informacje o sobie w zakresie zainteresowań, osobowości, wartości, jakie wyznaje w życiu. Przegląd samego siebie jest wyznacznikiem samorozwoju. Wyznaczone cele powinny dotyczyć przyszłości życiowo-zawodowej i uwzględniać dłuższą perspektywę czasową. Biorąc pod uwagę liczbę wyznaczanych celów, istotne staje się usystematyzowanie ich od najważniejszych do mniej ważnych. Następnie przypisujemy konkretne działania naszym celom, aby je zrealizować. Wyborowi celów i planowaniu nieodłącznie towarzyszy proces podejmowania decyzji. Aby droga do wyznaczania celów stała się łatwiejsza, przede wszystkim dobrze jest poznać samego siebie, swoje mocne i słabe strony, skupić się na możliwościach, nie zapominając jednak o ograniczeniach, pamiętać o swoich zainteresowaniach i zdolnościach. Dobra znajomość samego siebie umożliwia człowiekowi podejmowanie racjonalnych wyborów zawodowych, w których może odnieść spełnienie i sukces ${ }^{14}$.

\section{Poradnictwo grupowe jako forma wsparcia rozwoju zawodowego}
Gdy więcej niż jedna osoba współdziała harmo- nijnie i pracuje dla osiagnięcia celu, to dzięki jednoczeniu sit stawiaja siebie $w$ pozycji, która umożliwia im czerpanie mocy bezpośrednio z wielkiego magazynu Nieskończonej Inteligencji.

Napoleon Hill

Rozwój i wsparcie w podejmowaniu decyzji w sprawach kariery to dwa główne cele poradnictwa zawodowego. Na realizację tych celów składają się dwie strategie, czyli poradnictwo indywidualne i poradnictwo grupowe. Treści w tej części artykułu będą poświęcone czynnościom związanym z prowadzeniem grupowego poradnic-

${ }^{13}$ E.L. Herr, S.H. Cramer, Planowanie kariery zawodowej. Cz. I, Krajowy Urząd Pracy, Warszawa 2001, s. 34 .

${ }^{14}$ D. Pisula, Poradnictwo kariery przez całe życie, KOWEZiU, Warszawa 2009, s. 63. 
twa jako procesu kształtowania postaw. Z jednej strony uwzględniają rozwiązywanie wewnętrznych konfliktów, pozbywanie się wewnętrznych lęków, z drugiej zaś rozwojową istotę grupowego poradnictwa. Rozwój umiejętności interpersonalnych i społecznych, jak również uczenie umiejętności podejmowania decyzji przyczyniają się do efektywnego planowania kariery zawodowej.

Można z całą pewnością uznać, że w obecnych czasach poradnictwo zawodowe cieszy się dużym zainteresowaniem zarówno osób potrzebujących, jak i samych doradców zawodowych. Obejmuje pracę nad problemami osobistymi, edukacyjnymi, społecznymi i zawodowymi. Charakter pracy grupowej sprzyja poznaniu mocnych i słabych stron oraz ocenie możliwości i ograniczeń. Nabywanie nowych umiejętności podczas procesu grupowego ułatwia odnalezienie się w podejmowanych rolach społecznych i zawodowych. Często owe działania mają znaczenie terapeutyczne dla uczestników, gdyż podczas porad grupowych uczestnicy otwierają się, poznają na nowo swoje wewnętrzne potrzeby. Dostrzegają i lepiej wykorzystują emocjonalny aspekt swojego ja. Działaniom tym powinna sprzyjać atmosfera szacunku i akceptacji.

W procesie grupowego poradnictwa wykorzystuje się strategie rozwiązywania problemów oparte na świadomych myślach, emocjach i zachowaniu jednostek. Uczestnikami tych grup są na ogół osoby, które napotykają trudności na kolejnych etapach życia. Poszukują sposobów radzenia sobie w sytuacji kryzysowej, na przykład gdy kariera zawodowa nie jest zgodna $\mathrm{z}$ ich systemem wartości lub gdy nagle utraciły pracę, albo odczuwają brak możliwości realizowania się w roli zawodowej ${ }^{15}$. Działania grupowe dają uczestnikom punkt odniesienia do własnych problemów, potencjału, niedoborów w kontekście innych uczestników doradztwa grupowego ${ }^{16}$. Rozmowy na temat przeżyć i możliwość wymiany doświadczeń wiele znaczą dla uczestników, lecz nie zawsze są łatwe. Praktyka pokazuje, że ostateczny wynik to oczyszczenie wewnętrzne, zrozumienie siebie i innych. Na podstawie doświadczania mogą dokonywać samooceny własnych umiejętności i zdolności, a także otrzymywać informację zwrotną od grupy.

Różne problemy decydują o charakterze grupy, zaś o jej rodzaju świadczą pewne konkretne cechy. Cechy te mogą występować w różnym natężeniu, jednak powinny być wyraźne. Możemy wtedy być pewni, że mamy do czynienia z grupą. Im słabsze cechy, tym większa szansa, że jest to tylko skupisko osób. Pojęcie grupy stosowane w poradnictwie zawodowym możemy zdefiniować jako: „dwie albo więcej osób współpracujących ze sobą oraz współzależnych od siebie w tym sensie, że w zaspokajaniu potrzeb i osiąganiu celów muszą na sobie polegać" ${ }^{17}$. Są wzajemnie zależne od siebie, mają poczucie przynależności do grupy, wspólny cel, wpływ na siebie, poczucie, że grupa jest wartościowa. Prawdziwa grupa na drodze interakcji nabiera pewnej

${ }^{15}$ A. Paszkowska-Rogacz, M. Tarkowska, Metody pracy z grupa w poradnictwie zawodowym, KOWEZiU, Warszawa 2004, s. 41-42.

16 D. Pisula, Poradnictwo kariery przez całe życie, KOWEZiU, Warszawa 2009, s. 11.

17 A. Paszkowska-Rogacz, M. Tarkowska, dz. cyt., s. 46. 
dynamiki. Jej uczestnicy stale zmieniają się i dostosowują relacje do innych członków grupy. Zmienia się również stosunek samych uczestników do siebie. Takie sytuacje mają wywołać eliminację konfliktów w zamian za wypracowanie rozwiązania problemów. Zmiany, o których mowa, to tzw. dynamika grupy. Owa dynamika grupy ma ogromny wpływ na to, jak grupa pracuje i się zachowuje. Prowadzi ona do wypracowania technik skutecznego i efektywnego działania oraz podejmowania decyzji opartych na czynnikach ułatwiających lub utrudniających jej funkcjonowanie ${ }^{18}$. Do tych czynników możemy zaliczyć między innymi komunikację, podejmowanie decyzji, normy i wartości grupy, spójność, napięcie, strukturę grupy, powstawanie podgrup, wychodzenie naprzeciw problemom i rozwiązywanie konfliktów. Komunikacja interpersonalna to kluczowa umiejętność podczas pracy w grupie. Ułatwia relacje między uczestnikami i prowadzącym grupę. Wyrażanie emocji, poglądów jest zdecydowanie łatwiejsze, kiedy prowadzący identyfikuje się z sytuacjami uczestników, wyjaśnia, tłumaczy. Taka relacja zapobiega powstawaniu konfliktów.

Jak twierdzą Carmen Frutos-Mora i Rafael Piqueras Gomez, zadania realizowane w poradnictwie grupowym dla wszystkich grup odbiorców koncentrują się przede wszystkim wokół rozwiązania problemów. Owe problemy zawarte są w czterech wzajemnie ze sobą powiązanych obszarach: (1) obszar informacji koncentruje się na wiedzy, jaką uczestnik ma lub jaką chce mieć na temat rynku pracy, aby osiągnąć cel związany z zatrudnieniem, oraz w jaki sposób ją wykorzysta; (2) obszar umiejętności dotyczy odnajdywania się na wciąż zmieniającym się rynku pracy oraz autoprezentacji w sferze pracowniczej; (3) obszar planowania to nic innego jak zastosowanie strategii planu działania, aby skutecznie budować karierę zawodową; (4) obszar motywacji dotyczy wytrwałości w dążeniu do celu, czyli rozwiązania problemu. Ważna jest reakcja na ewentualne sukcesy bądź porażki. Istotne staje się rozwijanie i umacnianie $\mathrm{w}$ jednostce wysokiego poziomu zaangażowania w aktywność zawodową ${ }^{19}$.

W pracy grupowej stosowane są różne formy i techniki. Ich dobór zależy od osoby prowadzącej proces doradczy. Do grupy metod problemowych należą metody aktywne, inaczej: aktywizujące uczestników do rozwiązania danego problemu. W czasie pracy metodą warsztatową uczestnicy mają okazję do osobistego rozwoju i konfrontacji teorii z praktyką ${ }^{20}$. Aktywna metoda to takie działanie, które uwzględnia emocjonalny aspekt procesu zdobywania wiedzy i umiejętności, wykorzystując aktywną technikę w odpowiednim momencie i w odpowiedni sposób - do zewnętrznego organizowania sytuacji pracy z grupą. Istotą pracy grupowej staje się stwarzanie sytuacji i dobór technik, które dają możliwość aktywnego uczestnictwa każdej z jednostek w procesie grupowym. Dobór metod i ich zastosowanie to bardzo ważne elementy

${ }^{18}$ E.L. Herr, S.H. Cramer, dz. cyt., s. 144-145.

19 A. Martynuski i in., Rozwijanie indywidualnych cech ułatwiajacych zdobycie zatrudnienia, [w:] G. Morys-Gieorgica (red.), Zeszyty informacyjno-metodyczne doradcy zawodowego, Wojewódzki Urząd Pracy w Krakowie, Kraków 2002, s. 16-17.

${ }^{20}$ A. Paszkowska-Rogacz, M. Tarkowska, dz. cyt., s. 46. 
wpływające na skuteczność pracy w grupie. Muszą być przede wszystkim dostosowane do celu zajęć, treści, ram organizacyjnych, a w szczególności do potrzeb uczestników. Dzięki nim uczestnicy pogłębiają własne doświadczenia, nabywają potrzebną wiedzę i umiejętności, aby móc zaadaptować się do nowych warunków.

W poradnictwie grupowym opartym na metodach warsztatowych wykorzystuje się również poradnictwo indywidualne. Indywidualne rozmowy sprzyjają głębszemu poznaniu, nawiązaniu bliskiego kontaktu, wzmocnieniu motywacji, planowaniu konkretnych działań, rozwijaniu konkretnych umiejętności wspierających proces poszukiwania pracy ${ }^{21}$.

Trudno jest porównać obie wymienione formy pracy doradczej. Zarówno poradnictwo grupowe, jak i poradnictwo indywidualne służą realizacji innych celów. Można jednak zaobserwować dużą skuteczność pracy grupowej. Podczas pracy w grupie tworzy się atmosfera wsparcia, współpracy i zaufania. Konfrontacja z innymi uczestnikami prowadzi do wymiany doświadczeń, postaw, działań, o czym już wcześniej wspomniano. Uwzględniając poprawną dynamikę grupy, doradca i osoby radzące się mogą w dość krótkim czasie osiągnąć zamierzony cel, tj. rozwiązanie problemu.

\section{Czynniki wyboru zawodu}

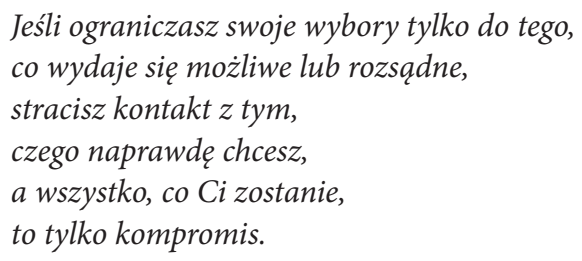

Robert Frity

W odniesieniu do kwestii wyboru zawodu można wykorzystywać wiele teorii rozwoju zawodowego. Najstarszą teorię rozwoju zawodowego człowieka, będącą teorią wyboru zawodu, stworzył Frank Parsons. Teoria cech i czynników zakłada, że wybór zawodu jest sprawą tylko wewnętrznych cech z pominięciem zewnętrznych warunków i okoliczności. Parsons określił najważniejsze elementy wyboru zawodu: jasne rozumienie siebie, swoich zdolności, możliwości, zainteresowań, ambicji i ograniczeń oraz ich przyczyn. Wyróżnił również wiedzę o warunkach sukcesu, niepewności, perspektyw w rozmaitych zawodach ${ }^{22}$. Autor teorii rozwoju Eli Ginzberg zaliczył do czynników mających wpływ na wybór zawodu między innymi: wartości jednostki, czynniki emocjonalne, stopień i rodzaj wykształcenia oraz naciski środowiskowe z otaczającej rzeczywistości. Prace Ginzberga stanowiły inspirację dla badań Supera

21 Tamże, s. 44.

${ }^{22}$ J. Jantura, Rozwój zawodowy człowieka, [w:] W. Trzeciak i in. (red.), Zeszyty informacyjno-metodyczne doradcy zawodowego, Krajowy Urząd Pracy, Warszawa 1994, s. 11. 
nad rozwojem zawodowym. Wyróżnił on trzy rodzaje czynników: czynnik roli, wiążący się z przyjęciem określonej roli zawodowej poprzez modelowanie, naśladownictwo i identyfikację z osobami znaczącymi dla jednostki; czynniki osobiste, takie jak nasze uzdolnienia, zainteresowania, wartości, postawy, osobowość; czynniki sytuacyjne, czyli położenie społeczno-ekonomiczne rodziców, przekonania religijne, sytuacja w domu, postawa rodziców wobec dzieci.

Do poszczególnych zawodów, jak głosi w swej teorii John Holland, predysponuje ludzi własna osobowość oraz wiele czynników wywodzących się z ich otoczenia. Wybór zawodu jest pochodną połączenia osobistych zainteresowań z możliwościami, jakie stwarza świat przed nami² ${ }^{23}$ Powyższe rozważania można wyrazić w postaci następujących stwierdzeń: wybór zawodu jest wyrazem osobowości; zawodowa satysfakcja jest uzależniona od zgodności osobowości jednostki ze środowiskiem; ludzie zaliczają się do jednego z sześciu typów osobowości (społecznego, realistycznego, intelektualnego, konwencjonalnego, przedsiębiorczego, artystycznego); ludzie poszukują takich zawodów, poprzez które będą mogli wykorzystać swoje umiejętności i zdolności oraz ujawnić swoje postawy i wartości. Konstruowanie wyżej wymienionych osobowości przypisuje się środowisku społecznemu, głównie rodzinie.

Z psychologicznego punktu widzenia lata wczesnego dzieciństwa wywierają decydujący wpływ na całe życie jednostki. Teoria psychodynamiczna, którą przedstawiła Anna Roe, odzwierciedla ten punkt widzenia. Zainteresowania rozwijają się podczas interakcji, jaka zachodzi między dziećmi a dorosłymi. Potrzeby zawodowe stanowią odzwierciedlenie chęci realizacji potrzeb niezaspokojonych przez rodziców w okresie dzieciństwa. Dlatego też jej zdaniem to właśnie okres dzieciństwa jest źródłem nieświadomej motywacji, wpływającej na wybory zawodowe, które umożliwiłyby zaspokojenie owych potrzeb. Wyróżniła trzy postawy rodziców wobec dziecka, które wpływają na wybór zawodu: akceptację, uczuciową koncentrację na dziecku, unikanie. Akceptacja występuje wówczas, gdy rodzice w pełni akceptują swoje dziecko jako członka rodziny, posiadającego zdolność wzięcia za siebie odpowiedzialności. Takie zachowania zdecydowanie sprzyjają wykorzystaniu możliwości i potencjału dziecka. Postawa koncentracji uczuciowej na dziecku występuje, gdy rodzice poświęcają zbyt dużo czasu i energii na wychowanie dziecka. Objawia się to jego kontrolowaniem. Taka sytuacja sprzyja tylko i wyłącznie ograniczaniu postawy dziecka. Może zdarzyć się, iż obowiązki nałożone przez rodziców przekraczają możliwości dziecka. Postawa unikania objawia się lekceważeniem dziecka i jego potrzeb. Brak zainteresowania wpływa negatywnie na dziecko ${ }^{24}$.

Łącząc przytoczone powyżej teorie, uzyskamy dwa rodzaje czynników wyboru zawodu: wewnętrzne i zewnętrzne. Do czynników wewnętrznych możemy zaliczyć zainteresowania, predyspozycje zawodowe, stan zdrowia, cechy osobowości, posta-

\footnotetext{
${ }^{23}$ A. Paszkowska-Rogacz, M. Tarkowska, dz. cyt., s. 18.

${ }^{24}$ J. Jantura, dz. cyt., s. 17.
} 
wy, wartości, stopień przyswajania wiedzy, zaangażowanie. Na czynniki zewnętrzne składają się zaś: system edukacyjny, przekazywana wiedza o zawodach, rynek pracy, atrakcyjność zawodu, wpływ rodziny, szkoły, rówieśników. W decyzjach zawodowych kluczowe znaczenie mają czynniki związane $\mathrm{z}$ indywidualnymi predyspozycjami. Jednakże jest to tylko punkt wyjścia skłaniający do zastanowienia się nad pewnymi kategoriami zawodów. Niektóre spośród psychologicznych teorii wyboru zawodu podkreślają, że człowiek ma predyspozycje do wykonywania kilku zawodów ${ }^{25}$. Trafność decyzji w wyborze zawodu wiąże się zatem z zakresem informacji o sobie samym, znajomością własnych ograniczeń i możliwości, ale także z poziomem zaangażowania i motywacji do wyboru zawodu. Wybór zawodu należy do pierwszych i jednych z najważniejszych decyzji, które przekładają się na późniejsze życie. Dlatego tak ważna staje się umiejętność i dojrzałość w podejmowaniu decyzji ćwiczona już od najmłodszych lat.

\section{Refleksje końcowe}

Musisz wzią́ za siebie odpowiedzialność.
Nie możesz zmienić okoliczności,
pór roku czy wiatru,
ale możesz zmienić samego siebie.

Jim Rohn

Kariera to całe życie zarówno prywatne, jak i zawodowe. Kreowanie własnej kariery zawodowej wymaga sprecyzowania celów na poszczególnych etapach życia. Zanim to jednak nastąpi, trzeba uświadomić sobie i zrozumieć mechanizmy rządzące światem. Zmiany, które dokonują się na przestrzeni czasu, wymuszają stosowanie pewnych działań jako strategii radzenia sobie i przystosowania do otaczającego świata, dlatego tak ważna staje się umiejętność planowania życia. Plan całożyciowy składa się z wielu celów etapowych. Jego stworzenie przynosi wiele korzyści. Osoba, która buduje karierę według określonego schematu, bierze pełną odpowiedzialność za życie. Dzięki temu ma poczucie, że jest kreatorem własnego losu. Nikt nie lubi, gdy ktoś kieruje jego życiem. Jeśli uda nam się być w pełni odpowiedzialnymi za siebie, staje się to wielką korzyścią i dużym krokiem w planowaniu kariery. Wybierając świadomie drogę zawodową, możemy mieć pełne poczucie słuszności własnego wyboru. Uświadamianie sobie mocnych i słabych stron daje impuls do analizy posiadanych możliwości. Jeśli plan nabiera tempa poprzez założone cele, odzwierciedla się w sukcesach i osiągnięciach. Zwiększa się motywacja do dalszego rozwoju. Dzięki takim

${ }^{25}$ M. Wolan-Nowakowska, Wybrane aspekty decyzji zawodowych i edukacyjnych młodzieży niepetnosprawnej, „Annales UMCS Sectico J Pedagogia-Psychologia” 2008, vol. XXI, s. 40. 
działaniom uzyskujemy większą skuteczność, swoją pozycję na rynku pracy odczuwamy jako bardziej bezpieczną, co prowadzi do wewnętrznej równowagi.

Rozmyślając na temat kwestii wyboru zawodu, uznaję, że najważniejsza jest odpowiedzialność za podejmowane decyzje życiowe i zawodowe. Pociąga to za sobą umiejętność rozpoznawania własnych możliwości i wartości, jakie wyznaje się w życiu. Ważną kwestią staje się znajomość zawodów, lecz nie pod względem przystosowania swoich umiejętności do wymagań zawodu, lecz doboru takiego zawodu, który w konsekwencji dana osoba będzie realizowała z pełną satysfakcją. Problemem młodzieży i osób dorosłych w Polsce jest nieumiejętność wyboru wymarzonego zawodu wynikająca $z$ braku odpowiedniego przygotowania do pracy nad sobą i korzystania $\mathrm{z}$ różnorodnych obszarów pomocowych.

Pomysłowość, kreatywność i upór w dążeniu do realizacji celu to dobry kierunek, aby doprowadzić do zmian, a pierwszym krokiem ku temu jest życie zgodnie z własnym ja, a niekiedy odkrycie siebie na nowo. Nadanie własnej karierze zupełnie nowego kierunku wydaje się niemożliwe z dnia na dzień. Podczas tego procesu możemy napotkać liczne trudne sytuacje. Dlatego trzeba wziąć pod uwagę wiele czynników i podjąć próbę opracowania własnych indywidualnych strategii. Zaplanowane strategie często mogą okazać się nieefektywne. W tej niełatwej gonitwie trzeba dać sobie czas, uzbrajając się w cierpliwość i wytrwałość. Jeśli przestaniemy wątpić w swoje umiejętności i zaczniemy odkrywać własny potencjał, to proces tworzenia satysfakcjonującej kariery ma szanse zrealizować się szybciej.

\section{Bibliografia}

Gladding S.T., Poradnictwo zawodowe - zajęcie wszechstronne, „Elipsa”, Warszawa 1994.

Herr E.L., Cramer S.H., Planowanie kariery zawodowej. Cz. I, Krajowy Urząd Pracy, Warszawa 2001.

Janas M., Poradnictwo grupowe, [w:] J. Fundowicz, I. Cholewa (red.), Zeszyty informacyjno-metodyczne doradcy zawodowego, Urząd Pracy, Warszawa 1994.

Jantura J., Rozwój zawodowy człowieka, [w:] W. Trzeciak i in. (red.), Zeszyty informacyjno-metodyczne doradcy zawodowego, Krajowy Urząd Pracy, Warszawa 1994.

Kargulowa A., O teorii i praktyce poradnictwa, PWN, Warszawa 2005.

Kulka D., Bednarczyk Ł., Poradnictwo zawodowe dla osób z grupy szczególnego ryzyka, Difin, Warszawa 2010.

Kwiatkowski S.M., Madalińska-Michalak J., Przywództwo edukacyjne, współczesne wyzwania, Wolters Kluwer, Warszawa 2014.

Lamb R., Poradnictwo zawodowe w zarysie, Krajowy Urząd Pracy, Warszawa 1998.

Lelińska K., Zawodoznawstwo w planowaniu kariery, OHP, Warszawa 2006. 
Martynuski A. i in., Rozwijanie indywidualnych cech ułatwiajacych zdobycie zatrudnienia, [w:] G. Morys-Gieorgica (red.), Zeszyty informacyjno-metodyczne doradcy zawodowego, Wojewódzki Urząd Pracy w Krakowie, Kraków 2002.

Minta J., Od autora do autora. Wspieranie młodzieży w konstruowaniu własnej kariery, KOWEZiU, Warszawa 2012.

Paszkowska-Rogacz A., Tarkowska M., Metody pracy z grupa w poradnictwie zawodowym, KOWEZiU, Warszawa 2004.

Pielok C., Poradnictwo zawodowe od początku - co to jest, dla kogo, po co?, [w:] Kwartalnik - doradca zawodowy, Ecorys Polska, Warszawa 2009.

Pisula D., Poradnictwo kariery przez całe życie, KOWEZiU, Warszawa 2009.

Wasilewski J., Kariery społeczno-zawodowe dyrektorów, Zakład Narodowy im. Ossolińskich - Ossolineum, Wrocław 1981.

Wojtasik B., Podstawy poradnictwa kariery, KOWEZiU, Warszawa 2011.

Wolan-Nowakowska M., Wybrane aspekty decyzji zawodowych i edukacyjnych młodzieży niepetnosprawnej, „Annales UMCS Sectico J Pedagogia-Psychologia” 2008, vol. XXI.

\section{Akty prawne}

Ustawa z dnia 20 kwietnia 2004 r. o promocji zatrudnienia i instytucjach rynku pracy, Dz.U. 2004, nr 99, poz. 1001.

\section{Career planning - an overview of selected forms of support}

Abstract: The aim of the article is to analyse the career planning process and review selected forms of support. The key question is - how can one consciously shape one's own career path? There are many different aspects to consider when choosing the right career planning strategies. Creating an individual path of professional development involves skills, abilities, qualifications and personality traits. The basic principle of planning professional development is to know your abilities and limitations to be able to improve yourself in order to give direction to your career. The article contains an overview of the activities carried out within the framework of vocational guidance addressed to young people and adults.

Keywords: career, development, guidance counsellor, career counselling

\footnotetext{
About the author: Katarzyna Błachnio - PhD student at The Maria Grzegorzewska University in Warsaw - in the field of pedagogy. As part of her doctoral dissertation she conducts research on the role of the father in the family. Her academic interests focus on the social sciences.
} 
Natalia Mandecka* iD https://orcid.org/0000-0002-3970-676X

SWPS Uniwersytet Humanistycznospołeczny

https://doi.org/10.25312/2083-2923.16/2019_02nm

\title{
Wypalenie rodzicielskie - nowe spojrzenie na przemęczonych rodziców. Przegląd literatury oraz badań
}

\begin{abstract}
Streszczenie: Treść artykułu jest przeglądem zagranicznych badań, które doprowadziły do opisania i zbadania zjawiska, jakim jest wypalenie rodzicielskie. Przedstawia on historię tego, w jaki sposób rozwinął się ogólny zamysł badań na ten temat; cechy charakterystyczne wypalenia rodzicielskiego oraz jego przyczyny. Artykuł prezentuje również najnowsze badania związane z czynnikami, które mogą wpływać na dane zjawisko. Są to badania zagraniczne, gdyż w Polsce konstrukt wypalenia nie był jak dotąd poruszany, choć jest to ważne zjawisko dla nauk humanistycznych i społecznych.
\end{abstract}

Słowa kluczowe: wypalenie, wypalenie rodzicielskie, dystansowanie emocjonalne, poczucie daremności, wychowanie, wyczerpanie fizyczne i psychiczne

\section{Wstęp}

Nikt nigdy nie powiedział, że bycie rodzicem to prosta sprawa. Jest to rodzaj pracy, która jest bezpłatna, pełna nadgodzin, pozbawiona możliwości wzięcia urlopu oraz wymagająca dyspozycyjności całą dobę. Jest to ponadto typ pracy, w której nie ma ścieżki awansów czy też benefitów w rodzaju karty multisport, znanych większości zatrudnionych. Nic dziwnego zatem, że zjawisko wypalenia zaczęto badać w odniesieniu do kwestii rodzicielstwa - jako zagadnienia wywodzącego się z badań związanych $\mathrm{z}$ wypaleniem zawodowym. Aby w pełni zrozumieć to zjawisko, należy cofnąć się do pierwotnych badań nad wypaleniem w miejscu pracy, które zapoczątkowano w latach siedemdziesiątych XX wieku.

* Natalia Mandecka - anglistka, studentka psychologii. Do jej zainteresowań naukowych należy teoria autodeterminacji, badania związane z satysfakcją i moralnością, psychologia różnic indywidualnych, a także sposób prezentowania aspektów psychologicznych w literaturze. 
Prekursorami badań dotyczących wypalenia są Herbert Freudenberger oraz Christina Maslach. Zaobserwowali oni niepokojące zmiany u pracowników społecznych. Każde z nich podeszło do tematu w inny sposób. Freudenberger badał aspekty kliniczne wypalenia, tj.: drażliwość, apatię, ciągłe zmęczenie, zwiększoną podatność na zachorowania u wolontariuszy, zaś Maslach skupiła się na specyfikacji i dynamice samego zjawiska, zastanawiając się, w jaki sposób osoby cierpiące na wypalenie zawodowe postrzegały siebie i innych, jakie uczucia były z tym związane oraz jak wpływało to na ich kompetencje.

Herbert Freudenberger, jak wspomniano, skoncentrował się na aspekcie klinicznym, badając wolontariuszy w ośrodku dla uzależnionych od narkotyków. W trakcie badań wykrył, że osoby, które cierpią na wypalenie zawodowe, wykazują specyficzne oznaki fizyczne i behawioralne. Wśród objawów fizycznych można zaobserwować: ciągłe zmęczenie, poczucie przeszywającego zimna, bezsenność, brak tchu. Zaś oznaki behawioralne to: łatwość popadania w złość, ciągła irytacja oraz frustracja. Freudenberger tłumaczył to tym, że osoba wypalona nie jest w stanie utrzymać w sobie emocji, jest płaczliwa. Ponadto w bardziej zaawansowanych przypadkach u takiej osoby może występować nadmierna podejrzliwość lub paranoja ${ }^{1}$.

Drugą osobą, dzięki której została zgłębiona koncepcja wypalenia zawodowego, jest Christina Maslach, która skupiła się na społecznym i psychologicznym aspekcie badań. W swoich badaniach zajęła się osobami pracującymi społecznie i po wielu latach zauważyła, że ludzie, którzy cierpią na wypalenie zawodowe, wykazują trzy główne cechy: wyczerpanie/zmęczenie, depersonalizację oraz poczucie daremności wykonywanego działania. Dodatkowo Maslach podkreśliła w swoich badaniach, że wypalenie zawodowe jest uwarunkowane nie tylko warunkami w miejscu pracy, ale też indywidualnymi cechami danej osoby. Do tych ostatnich zaliczamy: czynniki społeczne (wiek i edukację), rodzaj osobowości oraz postawę wobec pracy. Te zmienne sprawiają, że kwestia wypalenia zawodowego jest konstruktem złożonym z cech środowiskowych i cech indywidualnych osoby ${ }^{2}$.

Na podstawie tych badań oraz teorii powstają nowe projekty badawcze, które rozwijają naukę i starają się wyjaśnić zjawisko wypalenia. Należy zaznaczyć, że najbardziej popularnym naukowcem zajmującym się tą kwestią jest Wilmar Schaufeli. Dzięki niemu badania Herberta Freudenbergera i Christiny Maslach są wzbogacane i rozwijane, a narzędzia używane do pomiaru zjawiska wypalenia są łatwo przekształcane w wielu aspektach życia - w tym w wypaleniu rodzicielskim.

${ }^{1}$ H.J. Freudenberger, Staff Burn-Out, "Journal of Social Issues" 1974, Vol. 30, No. 1, s. 160.

2 C. Maslach, W.B. Schaufeli, M.P. Leiter, Job Burnout, "Annual Review of Psychology" 2001, Vol. 52, No. 1, s. 399-409. 


\section{Dotychczasowe badania wypalenia rodzicielskiego}

Wypalenie rodzicielskie nie jest może najnowszym konstruktem w badaniach naukowych, jednakże dopiero ostatnimi laty stworzono nowe metody, które pozwoliły potwierdzić istnienie tego zjawiska i dokładniej je zbadać. Było to niezwykle trudne, jako że pierwsze próby albo były skoncentrowane jedynie na grupie matek, albo wyłącznie na rodzicach dzieci cierpiących na choroby przewlekłe.

Pierwsze badania, których przedmiotem było wyczerpanie rodzicielskie, miały miejsce pod koniec lat osiemdziesiątych XX wieku, czyli dwadzieścia lat po pierwszych badaniach poświęconych kwestii wypalenia. Stwierdzono z czasem, że problem wypalenia jest związany nie tylko ze sferą pracy, ale też z innymi aspektami, szczególnie $\mathrm{z}$ aspektem bycia rodzicem. Jednym z pierwszych naukowców, który poruszył ten problem, był Dennis Pelsma. W 1989 roku chciał udowodnić występowanie tego zjawiska na grupie badawczej złożonej z samych matek ${ }^{3}$. Zbadał 100 niepracujących matek małych dzieci i skoncentrował się na dwóch z trzech czynników, o których była mowa na początku artykułu - na wyczerpaniu emocjonalnym oraz poczuciu bezsensowności w wychowywaniu swoich dzieci. Następnie temat podjęła Annika Norberg, która postanowiła zbadać, w jaki sposób aspekt wypalenia rodzicielskiego wpływa na rodziców dzieci, które wygrały walkę z rakiem mózgu ${ }^{4}$, oraz jak to może oddziaływać na ich codzienne życie ${ }^{5}$. Kolejnym badaczem wypalenia rodzicielskiego była Caisa Lindström. Podobnie jak Annika Norberg skupiła się na tematyce klinicznej i swoimi badaniami objęła rodziców dzieci chorych na cukrzycę typu pierwszego ${ }^{6}$.

Dzięki powyższym badaniom zauważono, że problemy odnoszące się do zagadnienia wypalenia rodzicielskiego są dość dyskusyjne, jeżeli chodzi o samo zbadanie aspektu wypalenia rodzicielskiego jako zjawiska. Udowodniono jednak, że rodzice dzieci, które zmagały się z chorobami, przeżywają wypalenie rodzicielskie. Niemniej, największy wkład wniosło badanie Pelsmy, który udowodnił, że kwestionariusz Christiny Maslach może zostać użyty jako podstawa do dalszych badań na temat zjawiska. Zagadnienie ponownie podjęła Isabelle Roskam, która stworzyła kwestionariusz mający udowodnić wszystkie trzy wymiary wypalenia rodzicielskiego, tj.: dystansowanie się emocjonalne od dziecka, wyczerpanie psychiczne i emocjonalne

${ }^{3}$ D.M. Pelsma, B. Roland, N. Tollefson, H. Wigington, Parent Burnout: Validation of the Maslach Burnout Inventory with a Sample of Mothers, "Measurement and Evaluation in Counseling and Development" 2018, Vol. 22, s. 82-87.

${ }^{4}$ A.L. Norberg, Burnout in mothers and fathers of children surviving brain tumour, "Journal of Clinical Psychology in Medical Settings" 2007, Vol. 14, s. 130.

${ }^{5}$ A.L. Norberg, Parents of children surviving a brain tumour: burnout and the perceived disease-related influence on everyday life, "Journal of Pediatric Hematology/Oncology" 2010, Vol. 32, s. 285.

${ }^{6}$ C. Lindström, Parental burnout in relation to sociodemographic, psychosocial and personality factors as well as disease duration and glycaemic control in children with Type 1 diabetes mellitus, "Acta Pediatrica" 2011, Vol. 100, s. 1011. 
oraz poczucie daremności bycia rodzicem. Przeprowadziła ona badania na dwóch ogromnych grupach - pierwsza liczyła 379 rodziców, druga aż 1723. Wykorzystała wcześniej stworzone narzędzia i w pełni potwierdziła istnienie zjawiska wypalenia rodzicielskiego ${ }^{7}$.

\section{Czym jest wypalenie rodzicielskie?}

Wyobraźmy sobie pewną sytuację, która pozwoli dobrze zrozumieć rodzica cierpiącego na wypalenie rodzicielskie. Isabelle Roskam podała przykład Krystyny, która jest matką trójki dzieci i swoje życie ułożyła tak, aby jak najbardziej je wspierać podczas okresu dorastania. Zdawała sobie sprawę, jak ważne jest, by każde dziecko otrzymało tyle ciepła i wsparcia, ile potrzebuje. Dzieci były regularnie zawożone do szkoły i z niej odbierane. Krystyna zabierała je na dodatkowe lekcje, przygotowywała im posiłki, prała oraz poświęcała odpowiednio dużo czasu na pomoc w nauce. Sytuacja zmieniła się jednak w ostatnim roku, gdy jej najstarsze dziecko uległo wypadkowi i potrzebowało rehabilitacji trzy razy w tygodniu, na którą trzeba było je dowozić. Dodatkowo najmłodsze dziecko Krystyny właśnie rozpoczęło naukę w szkole podstawowej i nie radziło sobie $\mathrm{z}$ nauką. Zakres obowiązków kobiety związanych $\mathrm{z}$ domem i pracą zwiększał się w zastraszającym tempie, a jej mąż nie był w stanie pomóc, ponieważ bardzo późno wracał do domu i często wyjeżdżał służbowo za granicę. Z czasem Krystyna miała coraz mniej czasu na zajmowanie się dziećmi w taki sposób, jak chciała. Musiała pogodzić pracę, dom, rehabilitację oraz czas na naukę, a także zaspokajanie potrzeb emocjonalnych dzieci. Stawała się coraz bardziej poirytowana i zmęczona całą sytuacją, a dzieci coraz częściej mówiły, że się zmieniła, przez co Krystyna zaczęła myśleć, że jest przykładem porażki rodzicielskiej .

Powyższy przykład pokazuje, na czym polegają trzy oznaki wypalenia rodzicielskiego:

1. Dystansowanie się emocjonalne - oznacza, że rodzic nie pozwala sobie na bliższe więzi emocjonalne z dziećmi. Przykładowo kiedy dzieci odnoszą sukcesy czy porażki, emocje rodzica są utemperowane i nie są adekwatne do danej sytuacji. Można tu nawiązać do osób, które doznały przemocy fizycznej w dzieciństwie, a po latach opowiadają o tym, jakby były obok, a nie w centrum zdarzeń. W przypadku Krystyny z omawianego przykładu objawia się to tak, że pomaga ona swoim dzieciom w sposób mechaniczny - przygotowuje posiłki, pierze, odprowadza do szkoły, ale nie jest w stanie odpowiadać na ich potrzeby emocjonalne, takie jak wysłuchanie, jakie problemy czy rozterki obecnie przeżywają.

${ }^{7}$ I. Roskam, M.E. Raes, M. Mikolajczak, Exhausted Parents: Development and Preliminary Validation of the Parental Burnout Inventory, "Frontiers in Psychology" 2017, Vol. 8.

8 Tamże. 
2. Wyczerpanie fizyczne i psychiczne - oznacza dosłowne oznaki przemęczenia, takie jak: bezsenność, bóle głowy, brak ochoty na jedzenie, zwiększona podatność na zachorowania, ale też ciągłe poczucie zmęczenia, wzmożona irytacja oraz frustracja. Myśl o tym, że trzeba zająć się potomstwem, wywołuje u rodzica zmęczenie i niechęć do działania. Co ciekawe, według badań Roskam wyczerpani rodzice przyznawali, że odczuwali takie symptomy przynajmniej raz w tygodniu ${ }^{9}$. U Krystyny z naszego przykładu objawia się to następująco: kobieta czuje się zmęczona już po obudzeniu, kiedy tylko pomyśli, ile rzeczy musi zrobić dla dzieci. Dodatkowo każda prośba dziecka - w sytuacji gdy Krystyna ma dokładnie zaplanowany dzień, a prośba wymaga zmiany planów może skutkować reakcją połączoną z irytacją, przy czym wszelkie zajęcia do tej pory sprawiające jej przyjemność (np. wspólna zabawa czy odrabianie lekcji) będą wzbudzały w niej niechęć.

3. Poczucie daremności - oznacza, że rodzic czuje, iż bez względu na to, co zrobi i jak zareaguje, to i tak będzie to niewystarczające. Inaczej mówiąc, rodzic nie wierzy już, że jakiekolwiek nakłady na dziecko (rozumiane jako poświęcanie dziecku uwagi i czasu, rozmowy, wspólnie spędzony czas, by nauczyć dziecko nowych rzeczy) dadzą zamierzony skutek. Rodzic w tym przypadku czuje się nieważny, ponieważ dziecko i tak decyduje inaczej, niż by chciał. Wracając do przykładu Krystyny, może ona odczuwać daremność, ponieważ poświęcanie dziecku czasu na pomoc w nauce nie daje efektów w postaci poprawy ocen. Tak samo może być w przypadku dziecka najstarszego, któremu Krystyna pomaga jak może, ale ono nie odczuwa w żaden sposób jej wkładu pracy w rehabilitację i nie widzi, ile to dla niej znaczy.

Są to te same oznaki, jakie występują przy wypaleniu zawodowym, z jedną różnicą - by móc określić, że ktoś jest wypalony zawodowo, musi dojść do depersonalizacji. W przypadku rodziców nie zachodzi depersonalizacja potomstwa tylko dystansowanie się emocjonalne ${ }^{10}$.

\section{Co wpływa na wypalenie rodzicielskie}

Skoro już znamy historię powstania zjawiska wypalenia rodzicielskiego oraz badania i adekwatne narzędzie pomiarowe, skupmy się na analizowanej przez badaczy kwestii, które $\mathrm{z}$ aspektów mogą wskazywać oraz wpływać na wystąpienie owego zjawiska.

Pierwsze badanie poświęcone temu zagadnieniu przeprowadziły w 2017 roku Sarah Le Vigouroux, Celine Scola, Marie Raes, Moira Mikołajczak i Isabelle Roskam. Badanie nosi nazwę The big five personality traits and parental burnout: Protective and risk factors i koncentruje się na zmierzeniu wyników wielkiej piątki osobowości

\footnotetext{
9 Tamże.

10 Tamże.
} 
i cech, które wpływają na wypalenie rodzicielskie. Grupa badawcza, na której przeprowadzono badanie, wynosiła 1723 rodziców (w tym 1499 matek), w przedziale wiekowym pomiędzy 20. a 75. rokiem życia $(M=40$ lat, $S D=8$ lat i 3 miesiące). Badanie odbywało się w Belgii i zostało przeprowadzone za pomocą kwestionariusza online. Jednym z ciekawszych warunków uczestnictwa w badaniu była deklaracja rodziców, że mieszkają razem z przynajmniej jednym swoim dzieckiem (nieważne, czy dziecko było małe, czy dorosłe). Do analizy wyników wykorzystano model addytywny (GAM), który pozwolił na pomiar nieliniowych zmian (np. związanych z wiekiem) w stanie wypalenia rodzicielskiego ${ }^{11}$. Na podstawie tych badań oraz poprzednich ustalono, że wypalenie rodzicielskie wiąże się z niską samooceną matek, ale także z ogromnymi ambicjami, które w trakcie wychowywania dziecka doprowadzają do wypalenia ${ }^{12}$. Wyszczególniono cechy indywidualne i cechy osobowościowe wpływające na zjawisko wypalenia rodzicielskiego, takie jak:

1. Niestabilność emocjonalna (neurotyzm) - zgodnie z hipotezą badaczy rodzice, którzy uzyskali wysoki poziom na skali neurotyczności, są bardziej narażeni na wypalenie rodzicielskie $\left(s^{2}=1\right.$, gdzie $12,5 \%$ różnic w wypaleniu rodzicielskim można wyjaśnić tą zmienną) $)^{13}$.

Dana cecha znacząco wpływa na nadmierne zamartwianie się, ale także na potrzebę kontroli oraz poczucie odpowiedzialności za zachowania dziecka; rodzice o wysokim poziomie neurotyczności bardziej przeżywają wydarzenia z życia dziecka (głównie te negatywne), ponadto przez brak stabilności emocjonalnej nie są w stanie porozumiewać się adekwatnie $\mathrm{z}$ dziećmi ${ }^{14}$. Dodatkowo cecha ta może doprowadzić do wzrostu negatywnych kontaktów z dzieckiem, które mogą wynikać z braku wiary we własne kompetencje jako rodzica i z narastającej frustracji. Może to prowadzić do nadopiekuńczości, która nie zostawia dziecku miejsca na swobodę i skutkuje surowym wychowaniem, przez które dziecko nie otrzymuje potrzebnego wsparcia, ciepła czy też uporządkowanych relacji z rodzicem ${ }^{15}$.

2. Sumienność - osoby, które miały wysoki wynik w tej skali, uzyskały niższy wynik w skali wypalenia rodzicielskiego $\left(s^{2}=2,27\right.$, gdzie $4,4 \%$ różnic w wypaleniu rodzicielskim można wyjaśnić tą zmienną) ${ }^{16}$, ponieważ potrafią dostosować się do obecnych warunków i wymagań systemu edukacji. Taki rodzic jest

${ }^{11}$ S. Le Vigouroux, C. Scola, M.E. Raes, M. Mikolajczak, I. Roskam, The big five personality traits and parental burnout: Protective and risk factors, "Personality and Individual Differences" 2017, Vol. 119, s. 217.

12 Tamże, s. 216.

13 Tamże, s. 217.

14 Tamże, s. 216.

${ }_{15}$ P. Prinzie, G.J.J.M. Stams, M. Deković, A.H.A. Rejintjes, J. Belsky, The relations between parents' big five personality factors and parenting: a meta-analytic review, "Journal of Personality and Social Psychology" 2009, Vol. 97, s. 352.

${ }^{16}$ S. Le Vigouroux i in., The big five..., dz. cyt., s. 217. 
lepiej przystosowany do wymagań, z jakimi przyjdzie mu się zmierzyć podczas wychowywania dzieci, oraz cechuje się większą konsekwencją w działaniu. Dodatkowo sumienność jest cechą, która określa uporządkowanie i zorientowanie na cel w połączeniu z wysokimi standardami. Istnieje zatem duże prawdopodobieństwo, że osoba o wysokim stopniu sumienności będzie w stanie zapewnić dziecku uporządkowane i spójne miejsce dorastania ${ }^{17}$.

3. Ugodowość - rodzice, którzy otrzymali wysoki wynik na tej skali, wyróżniali się najbardziej w kwestii odporności na wypalenie rodzicielskie $\left(s^{2}=5,48\right.$, gdzie 6,09\% różnic w wypaleniu rodzicielskim można wyjaśnić tą zmienną).

Cecha ugodowości przejawia się poprzez bycie przyjaznym, empatycznym, uczynnym dla innych. Osoby ugodowe są ogólnie uznawane za ciepłe. Rodzic, który wykazuje taką cechę, ma ciepłą relację ze swoim dzieckiem. Będzie starał się zrozumieć jego problemy, pomagać mu w realizacji jego planów i wspierać $j^{18}$. Należy dodać, że rodzice charakteryzujący się wysokim poziomem ugodowości posiadają zdolność identyfikowania i rozumienia potrzeb dziecka oraz okazywania mu odpowiedniej empatii. Są to rodzice wyrozumiali i empatyczni, więc można założyć, że będą potrafili zapewnić dziecku wspierające środowisko niezbędne do budowania jego niezależności ${ }^{19}$.

4. Ekstrawersja i otwartość na doświadczenia - wyniki badań wykazały, że obie te cechy nie mają większego wpływu na zjawisko wypalenia rodzicielskiego (nie podano niestety dokładnych danych na ten temat).

Ekstrawersja oznacza dynamiczność, energię, chęć przebywania w dużych grupach ludzi. Rodzice posiadający tę cechę są chętni do rozmów i często wykazują chęć dominacji w swoim otoczeniu. Są lepsi w dyscyplinowaniu swoich dzieci, gdyż wierzą w bardziej aktywne formy wychowania.

Otwartość na doświadczenia to cecha sprawiająca, że rodzic jest chętny do odkrywania nowych rzeczy, zainteresowań oraz do wspólnej aktywności z dzieckiem, dzięki czemu zachęca je do nowych działań ${ }^{20}$.

Obie te cechy są do siebie bardzo podobne, jeżeli weźmiemy pod uwagę aspekt wychowania dzieci. Zauważył to już Prinzie w swoim artykule, stwierdzając, że rodzice $\mathrm{z}$ wysokimi wynikami na powyższych skalach cechują się kreatywnością oraz zachęcają swoje dzieci do socjalizowania się czy też odkrywania i doświadczania nowych rzeczy ${ }^{21}$.

Nawiązując do powyższych badań, można wywnioskować, że rodzice charakteryzujący się dużym nasileniem neurotyzmu oraz niskimi wynikami w zakresie ugodowości i sumienności są najbardziej narażeni na wypalenie rodzicielskie. Dodatkowe

17 P. Prinzie i in., dz. cyt., s. 353.

18 S. Le Vigouroux i in., The big five..., dz. cyt., s. 217.

19 P. Prinzie i in., dz. cyt., s. 353.

20 S. Le Vigouroux i in., The big five..., dz. cyt., s. 217.

21 P. Prinzie i in., dz. cyt., s. 353. 
czynniki, które są predykatorami wypalenia, to nadopiekuńczy i zbyt kontrolujący styl wychowywania, a także brak umiejętnego odczytywania potrzeb dziecka oraz chaos $\mathrm{w}$ środowisku rodzinnym. Zaś rodzice, którzy umieją odpowiedzieć na potrzeby dziecka, rozwijają w nim autonomiczność i są w stanie zapewnić harmonię w domu rodzinnym, wykazywali najmniejszą podatność na to zjawisko. Dodatkowo stwierdzono, że wysokie wyniki na skali ugodowości i sumienności są czynnikami ochronnymi, które mogą zapobiec wystąpieniu wypalenia rodzicielskiego ${ }^{22}$.

Kolejne badanie przeprowadzone przez Sarah Le Vigouroux i Celine Scolę również miało na celu zbadanie osobowości rodziców i czynników demograficznych, które mogą wpływać na zjawisko wypalenia rodzicielskiego. Badanie zostało opublikowane w artykule Differences in Parental Burnout: Influence of Demographic Factors and Personality of Parents and Children. Określono trzy cele: potwierdzenie wcześniej otrzymanych wyników, sprawdzenie czynników socjodemograficznych (takich jak wiek rodzica, wiek dziecka, liczba dzieci) oraz potwierdzenie, jak duże znaczenie mają cechy osobowości rodzica w przypadku występowania zjawiska wypalenia rodzicielskiego.

W grupie badawczej znalazło się 372 rodziców (w tym 314 matek) w wieku 2365 lat $(M=36,76, S D=7,57)$, a pierwsze dziecko w rodzinie pojawiło się w przedziale 19-47 lat $(M=29,66, S D=4,44)$. Tak samo jak poprzednio udział w badaniu mogli wziąć rodzice, którzy mieszkali nadal przynajmniej z jednym dzieckiem ${ }^{23}$. Do celów badawczych użyto trzech kwestionariuszy: wskaźnika wypalenia rodzicielskiego $\left(\mathrm{PBI}^{24}\right)$, francuskiej adaptacji kwestionariusza BFQ, który mierzy cechy osobowości ${ }^{25}$, oraz Ten -Item Personality Inventory ${ }^{26}$, który wypełnia rodzic, oceniając charakter dziecka.

Wyniki badań pokazały, że ani liczba posiadanych dzieci - bez względu na to, czy mieszkały jeszcze z rodzicami, czy poza domem $(r=0,15, p<0,01)$, ani duża różnica wieku pomiędzy dziećmi $(r=0,13, p<0,05)$ nie wpływają znacząco na wypalenie rodzicielskie. Dodatkowo takie zmienne socjodemograficzne, jak wiek rodzica $w$ trakcie badania czy wiek, w jakim urodziło się pierwsze dziecko, okazały się nieistotne dla zjawiska $(r=0,01 \text { oraz } r=-0,03)^{27}$.

Porównanie powyższych zmiennych socjodemograficznych z trzema wymiarami wypalenia rodzicielskiego ujawniło bardzo interesujące wyniki. Należy wymienić:

1. Wyczerpanie emocjonalne - najwyższą korelację z tą zmienną uzyskali młodzi rodzice $(r=-0,16, p<0,01)$ oraz rodzice $\mathrm{z}$ małymi dziećmi $(r=-0,19$, $p<0,001)$.

${ }^{22}$ S. Le Vigouroux i in., The big five..., dz. cyt., s. 218.

${ }^{23}$ S. Le Vigouroux, C. Scola, Differences in Parental Burnout: Influence of Demographic Factors and Personality of Parents and Children, "Frontiers in Psychology" 2018, Vol. 9, s. 887.

${ }^{24}$ I. Roskam i in., Exhausted Parents..., dz. cyt.

${ }^{25}$ G.V. Caprara, C. Barbaranelli, L. Borgogni, M. Perugini, The „big five questionnaire”: A new questionnaire to assess the five factor model, "Frontiers in Psychology" 1993, Vol. 15, s. 281-288.

${ }^{26}$ S.D. Gosling, P.J. Rentfrow, W.B.J. Swann, A very brief measure of the Big-Five personality domains, "Journal of Research in Personality" 2003, Vol. 37, s. 504-528.

${ }^{27}$ S. Le Vigouroux, C. Scola, Differences..., dz. cyt., s. 887. 
2. Dystansowanie się emocjonalne - wysoki wynik korelacji pomiędzy tym wymiarem wypalenia rodzicielskiego jest widoczny w grupie rodziców, którzy posiadają wiele dzieci $(r=0,22, p<0,001)$, oraz wśród rodziców dzieci, u których występują duże różnice wieku $(r=0,14, p<0,01)$. Zaszła także korelacja z wczesnym wiekiem urodzenia pierwszego dziecka $(r=-0,11, p<0,05)$.

3. Poczucie daremności - najwyższe wyniki korelacji w tym wymiarze uzyskali starsi rodzice $(r=0,24, p<0,001)$, rodzice $z$ dużą liczbą dzieci $(r=0,14$, $p<0,01)$, a także rodzice, których dzieci były już starsze $(r=0,32, p<0,001)^{28}$.

Kolejny aspekt badania, który miał potwierdzić wcześniejsze wyniki oraz to, jakie cechy osobowości mają wpływ na wypalenie rodzicielskie w aspekcie osobowości rodziców, takie jak: ugodowość, sumienność oraz neurotyzm, okazał się bardzo owocny. Tak samo jak w poprzednich badaniach do uzyskania wyników wykorzystano analizę korelacji oraz wyliczenia z zastosowaniem addytywnego modelu (GAM).

Badania potwierdziły, że wysokie wyniki w zakresie występowania takich cech, jak ugodowość i stabilność emocjonalna (cecha, która jest odwrotnością neurotyczności) najbardziej chronią przed wypaleniem rodzicielskim $(r=-0,20, p<0,001$ i $r=-0,42, p<0,001)$. Co ciekawsze, autorzy badania zauważyli także, że umiejętność kontrolowania i regulowania emocji ma większe znaczenie ochronne niż kontrola impulsów $(r=-0,46, p<0,001$ i $r=-0,28, p<0,001)$.

Okazało się ponadto, że sama cecha, jaką jest sumienność, nie wykazuje statystycznego wpływu na wynik wypalenia rodzicielskiego $(r=0,02)$, aczkolwiek dwa poszczególne aspekty tej cechy, czyli wytrwałość i skrupulatność, wykazały korelację z wystąpieniem zjawiska. Zatem rodzice, którzy są bardziej wytrwali, są mniej narażeni na wypalenie oraz jego trzy wymiary $(r=-0,12, p<0,05)$, odwrotnie niż rodzice bardziej skrupulatni $(r=0,12, p<0,12)^{29}$.

\section{Podsumowanie}

$\mathrm{Na}$ proces wychowawczy dzieci składa się wiele różnych aspektów, między innymi ekonomiczny, środowiskowy i kulturowy. Nie można jednak zapominać, że najważniejszym czynnikiem jest relacja rodzica z dzieckiem. Większość modeli wychowawczych zakłada czynny udział rodzica w wychowywaniu i, jak podkreślono we wstępie, jest to ciężka praca. Tym bardziej trzeba pamiętać, że rodzice są podatni na wypalenie. To zjawisko zostało dokładnie opisane dopiero niedawno, badania w tej dziedzinie powinny być pogłębiane. Dzięki znanym dziś wynikom badań możemy wskazać, jakie cechy osobowości rodziców predysponują ich do wypalenia rodzicielskiego. Korzystając z tej wiedzy, można wdrożyć programy prewencyjne, które pozwolą walczyć z problemem wypalenia. Poprzez kontynuowanie badań w przyszło-

\footnotetext{
28 Tamże.

29 Tamże.
} 
ści będzie można dowiedzieć się, w jaki sposób wspierać rodziców wykazujących oznaki wypalenia, a także jak można przeciwdziałać temu zjawisku. Badania takie są bardzo ważne nie tylko z punktu widzenia psychologii rozwojowej i klinicznej, ale także pedagogiki, ponieważ umożliwią w przyszłości opracowanie nowego modelu wsparcia dla wypalonych rodziców oraz sposobu pomocy ich dzieciom. Należy pamiętać, że wypalenie rodzicielskie dotyczy nie tylko rodziców, ale także opiekunów dzieci (dziadków, nauczycieli itd.) w różnych placówkach, gdzie wymagana jest praca pod wpływem różnych emocji (pozytywnych bądź negatywnych) i nawiązanie więzi z dzieckiem.

W badaniach nad wypaleniem rodzicielskim należałoby się skupić również na dodatkowych aspektach, które mogą mieć wpływ na występowanie tego zjawiska. Ciekawe jest na przykład, czy wypaleni zawodowo rodzice są bardziej podatni na wypalenie rodzicielskie, jakie cechy osobowości dzieci sprzyjają występowaniu tego zjawiska i w jaki sposób relacja pomiędzy rodzicami wpływa na wypalenie rodzicielskie.

Obecnie prowadzone są badania w tym zakresie na populacji rodziców anglojęzycznych i francuskojęzycznych ${ }^{30}$. Jednakże badania polskich rodziców pokazałyby dodatkowe aspekty typowe dla populacji polskiej.

\section{Bibliografia}

Caprara G.V., Barbaranelli C., Borgogni L., Perugini M., The „big five questionnaire”: A new questionnaire to assess the five factor model, "Frontiers in Psychology" 1993, Vol. 15.

Freudenberger H.J., Staff Burn-Out, “Journal of Social Issues” 1974, Vol. 30, No. 1.

Gosling S.D., Rentfrow P.J., Swann W.B.J., A very brief measure of the Big-Five personality domains, "Journal of Research in Personality" 2003, Vol. 37.

Le Vigouroux S., Scola C., Differences in Parental Burnout: Influence of Demographic Factors and Personality of Parents and Children, "Frontiers in Psychology" 2018, Vol. 9.

Le Vigouroux S., Scola C., Raes M.E., Mikolajczak M., Roskam I., The big five personality traits and parental burnout: Protective and risk factors, "Personality and Individual Differences" 2017, Vol. 119.

Lindström C., Parental burnout in relation to sociodemographic, psychosocial and personality factors as well as disease duration and glycaemic control in children with Type 1 diabetes mellitus, "Acta Pediatrica" 2011, Vol. 100.

${ }^{30}$ I. Roskam, M.E. Brianda, M. Mikolajczak, A Step Forward in the Conceptualization and Measurement of Parental Burnout: The Parental Burnout Assessment (PBA), "Frontiers in Psychology" 2018, Vol. 9, s. 758-759. 
Maslach C., Schaufeli W.B., Leiter M.P., Job Burnout, "Annual Review of Psychology" 2001, Vol. 52, No. 1.

Norberg A.L., Burnout in mothers and fathers of children surviving brain tumour, "Journal of Clinical Psychology in Medical Settings" 2007, Vol. 14.

Norberg A.L., Parents of children surviving a brain tumour: burnout and the perceived disease-related influence on everyday life, "Journal of Pediatric Hematology/ Oncology" 2010, Vol. 32.

Pelsma D.M., Roland B., Tollefson N., Wigington H., Parent Burnout: Validation of the Maslach Burnout Inventory with a Sample of Mothers, "Measurement and Evaluation in Counseling and Development" 2018, Vol. 22.

Prinzie P., Stams G.J.J.M., Deković M., Rejintjes A.H.A., Belsky J., The relations between parents' big five personality factors and parenting: a meta-analytic review, "Journal of Personality and Social Psychology" 2009, Vol. 97.

Roskam I., Brianda M.E., Mikolajczak M., A Step Forward in the Conceptualization and Measurement of Parental Burnout: The Parental Burnout Assessment (PBA), "Frontiers in Psychology" 2018, Vol. 9.

Roskam I., Raes M.E., Mikolajczak M., Exhausted Parents: Development and Preliminary Validation of the Parental Burnout Inventory, "Frontiers in Psychology" 2017, Vol. 8.

\section{Parental Burnout - a new look at the 'exhausted parent' - A review of the literature}

Abstract: This article is a summary of international studies regarding Parental Burnout syndrome. The article describes the history of the studies and the main characteristics of parental burnout. It considers the predictors of burnout and the factors that lead to the development of the syndrome. The article is based on international studies, as no studies on the topic have been published in Poland.

Keywords: burnout, parental burnout syndrome, emotional distancing, sense of inefficacy, emotional and physical exhaustion, upbringing

About the author: Natalia Mandecka - an anglicist and a psychology student. Her main research interests are: the theory of self-determination, the feeling of happiness, the psychology of individual differences and how psychological aspects are presented in the literature. 


\title{
Agnieszka Deja* (iD https://orcid.org/0000-0003-3808-4660 \\ Uniwersytet Gdański
}

https://doi.org/10.25312/2083-2923.16/2019_03ad

\section{Działania podopiecznych destabilizujące relacje w rodzinnym domu dziecka}

\begin{abstract}
Streszczenie: Artykuł w sposób opisowy przedstawia problematykę znaczenia działań podopiecznych na destabilizację relacji w rodzinnym domu dziecka. Autorka artykułu przedstawia najpierw zmienność relacji w rodzinnych domach dziecka, a następnie prezentuje wyniki badań etnograficznych. Zaprezentowane analizy ukazują zależności pomiędzy działaniami podopiecznych a zaburzeniami relacji z pracownikami i innymi wychowankami rodzinnych domów dziecka. W artykule zostały przedstawione wybrane czynniki zakłócające relacje w rodzinnym domu dziecka, takie jak: agresja i autoagresja, bierność i wycofanie oraz postawa roszczeniowa podopiecznych rodzinnych domów dziecka.
\end{abstract}

Słowa kluczowe: działania destabilizujące, relacje społeczne, rodzinny dom dziecka

\section{Wprowadzenie}

W obliczu trudnej sytuacji bliskie i pozytywne relacje z innymi mogą pomóc jednostce w uporaniu się z przykrymi skutkami sytuacji i chronić ją od potencjalnych szkodliwych następstw dla zdrowia zarówno psychicznego, jak i fizycznego. Relacje, które obejmują wspieranie danej osoby, wcale nie muszą być rozległe, by właściwie spełniały swoją rolę. Już kilka bliskich, autentycznych i satysfakcjonujących relacji z innymi może stanowić potencjał, który człowiek może wykorzystać do radzenia sobie z trudnościami. Równocześnie negatywne relacje będą źródłem negatywnych

"Agnieszka Deja - doktorantka studiów z zakresu pedagogiki na Wydziale Nauk Społecznych Uniwersytetu Gdańskiego. Ukończone studia: pedagogika opiekuńczo-wychowawcza z terapią pedagogiczną, pedagogika społeczna. Zainteresowania: opieka zastępcza, rodzinne formy opieki zastępczej, rodzinne domy dziecka, interakcjonizm symboliczny. 
emocji i są bardziej szkodliwe niż subiektywne poczucie osamotnienia ${ }^{1}$. Niestety działania ludzkie cechuje zmienność, dlatego nigdy nie można mieć pewności, w jakim kierunku rozwinie się interakcja z naszym współpartnerem. Co więcej, również przestrzeń społeczna, czyli czas i miejsce, czyni warunki kontekstualne za każdym razem zmiennymi, przez co modyfikuje ostatecznie przebieg relacji. Gdy partnerzy interakcji zaczynają inaczej interpretować sytuacje i działania, mogą pojawiać się dysonanse na poziomie komunikacyjnym, a sam przebieg relacji może ulec zakłóceniu. Relacje pracowników z podopiecznymi rodzinnych domów dziecka mogą też ulec sytuacyjnemu załamaniu między innymi w wyniku agresji, autoagresji, bierności i wycofania oraz postawy roszczeniowej.

\section{Założenia metodologiczne}

Relacje dotyczą różnorodnych sytuacji życiowych, w których zachodzą wzajemne stosunki pomiędzy członkami w najbliższym środowisku życia ${ }^{2}$. Określone relacje mogą mieć charakter jednokierunkowy lub dwukierunkowy - przybierając postać interakcji ${ }^{3}$. Istotą interakcji jest równoczesne, wzajemne oddziaływanie, równoczesna psychiczna i behawioralna aktywność poszczególnych osób. Wzorzec pedagogicznych relacji ukazuje między innymi Stanisław Kawula ${ }^{4}$. Cechy tego modelu wskazują kierunek relacji:

- odejście od rywalizacji ku kooperacji,

- od konfliktowości do syntonii,

- od uprzedzeń emocjonalnych do skupienia się na zadaniach,

- od instrumentalizmu ku partnerstwu wszelkich podmiotów edukacyjnych.

Ten model może stanowić bazę do budowania relacji między pracownikami i podopiecznymi rodzinnych domów dziecka lub do ich załamania. Charakter takich relacji może prowadzić do pozytywnych, korzystnych zmian w dziecku oraz do wzbogacenia treści i charakteru samych relacji lub odwrotnie - do negatywnych emocji i destabilizacji relacji pomiędzy obiema grupami.

Termin destabilizacja ma wiele wymiarów znaczeniowych. W odniesieniu do kategorii relacji społecznych oznacza „stan, w którym relacje przestają lub przestały normalnie funkcjonować w wyniku istniejącej równowagi lub porządku”. Według

${ }^{1}$ J.K. Kiecolt-Glaser, R. Glaser, Stress and immune function in humans, [in:] R. Adler, D.L. Felten, N. Cohnen (eds.), Psychoneuroimmunology, Academic Press, New York 1991, s. 849-869.

${ }^{2}$ M. Tyszkowa, Psychologia rozwoju człowieka. T. 1, Wydawnictwo Naukowe PWN, Warszawa 1996, s. 132.

${ }^{3}$ V.G. Cicirelli, Sibling relationships throughout the life cycle, [in:] L. Abate (ed.), The handbook of family psychology and therapy, Vol. 95(1), Dorsey Press, Homewood 1985, s. 177-214.

${ }^{4}$ S. Kawula, Człowiek w relacjach socjopedagogicznych, Wydawnictwo Edukacyjne Akapit, Toruń 1999, s. 31.

${ }^{5}$ L. Drabik, E. Sobol, Słownik języka polskiego, Wydawnictwo Naukowe PWN, Warszawa 2018. 
Williama J. Goode’a destabilizacja to: „rozpad jedności (spoistości) grupy/rodziny oraz załamanie wzoru wypełniania ról społecznych, kiedy to jeden lub więcej członków nie wywiązuje się z realizacji zadań i obowiązków przypisanych konkretnej roli w grupie/rodzinie" . Dlatego właśnie przedmiotem badań uczyniono działania podopiecznych destabilizujące relacje w rodzinnych domach dziecka z punktu widzenia pracowników.

Celem artykułu jest analiza tych działań podopiecznych, które zaburzają relację w rodzinnym domu dziecka i dotyczą zarówno pracowników, jak i innych współmieszkańców. Z tego względu główne pytanie badawcze brzmi następująco: Jakie działania podopiecznych destabilizują relację $w$ rodzinnym domu dziecka?

Koncentrując się na opisie i analizie działań podopiecznych oraz relacji w rodzinnych domach dziecka, podjęto próbę zrozumienia danego „fragmentu” rzeczywistości oraz nakreślenia jego charakteru i specyfiki.

Materiał badawczy został zgromadzony podczas pobytu badacza w trzech rodzinnych domach dziecka znajdujących się na terenie województwa pomorskiego, tj. w Gdyni, Gdańsku i Malborku. Wszystkie wymienione placówki to domy prywatne, realizujące zadania opiekuńczo-wychowawcze oraz działające zgodnie $\mathrm{z}$ regulacjami zawartymi w stosownych aktach prawnych oraz określonych dokumentach wewnętrznych, takich jak statuty i regulaminy ${ }^{7}$. Osobami badanymi są małżeństwa w średnim wieku. Od wielu lat tworzą rodzinny dom dziecka i dzięki ich bogatemu doświadczeniu zawodowemu dowiedziałam się wielu interesujących faktów.

Rodzinny dom dziecka w Gdyni w dzielnicy Chwarzno funkcjonuje od 2007 roku. Jest prowadzony przez małżeństwo - żona ma 49 lat, mąż 39 lat - z 11-letnim stażem pracy. Małżeństwo opiekuje się ośmiorgiem dzieci powierzonych w wieku 8 miesięcy, 3 lata, 4 lata, 11 lat, 16 lat, 17 lat i dwoje podopiecznych 19-latków.

Rodzinny dom dziecka w Gdańsku w dzielnicy Złota Karczma funkcjonuje od 2012 roku. Jest prowadzony przez małżeństwo - żona ma 41 lat i 28-letni staż pracy, a mąż 39 lat i 6-letni staż pracy. Małżeństwo opiekuje się siedmiorgiem dzieci powierzonych: dwojgiem 10-latków oraz 11-latkiem, 12-latkiem, 14-latkiem, 17-latkiem i 18-latkiem.

Rodzinny dom dziecka w Malborku wdzielnicy Kałdowo funkcjonuje od 2009 roku. Jest prowadzony przez małżeństwo - żona ma 49 lat, mąż 53 lata z 9-letnim stażem pracy. Małżeństwo opiekuje się dziewięciorgiem dzieci powierzo-

${ }^{6}$ W. J. Goode, Family Disorganization, [in:] R.K. Merton, R.A. Nisbet (eds.), Contemporary Social Problems: An Introduction to the Sociology of Deviant Behavior and Social Disorganization, Harcourt, Brace \& World, New York 1961, s. 390-458 za: M. Piorunek, J. Kozielewska, A. Skowrońska-Pućka, Rodzina. Młodzież. Dziecko. Szkice z teorii i praktyki pomocy psychopedagogicznej i socjalnej, [w:] M. Grześko-Nyczka (red.), Istota i przejawy społecznego problemu dezorganizacji rodziny w Polsce po 1989 r., Wydawnictwo Naukowe, Poznań 2003, s. 90-91.

7 Ustawa z dnia 12 marca 2004 r. o pomocy społecznej, Dz.U. 2004, nr 64, poz. 593, a także Rozporządzenie Ministra Pracy i Polityki Społecznej z 14 lutego 2005 r. w sprawie placówek opiekuńczo-wychowawczych, Dz.U. 2005, nr 37, poz. 331. 
nych, w tym dziecko w wieku 9 lat, dwoje dzieci 10-letnich, 11-latek, dwoje dzieci w wieku 12 lat, 13-latek, 14-latek i 16-latek.

W badaniu zastosowałam metodę jakościową i wybrałam badanie etnograficzne ${ }^{8}$. W badaniach w rodzinnych domach dziecka wykorzystano takie techniki, jak obserwacja uczestnicząca jawna oraz wywiad częściowo ustrukturalizowany. Wybór określonej metody i technik podyktowany został chęcią uzyskania jak najlepszego obrazu badanego fragmentu życia społecznego w rodzinnych domach dziecka.

Etnografia nie jest dzisiaj jednolitą metodą uprawiania badań empirycznych, lecz $\mathrm{w}$ powiązaniu z różnymi orientacjami teoretycznymi tworzy bardzo rozbudowany system strategii badawczych. Zdaniem Roberta Prusa etnografia jest metodą badań, którą badacze posługują się w celu zaobserwowania działań ludzi oraz uchwycenia punktu widzenia i perspektywy postrzegania rzeczywistości przez członków określonej zbiorowości ${ }^{9}$. A zatem w terenowych badaniach etnograficznych badacz powinien zanurzyć się w świat swoich badanych, przyjmując ich perspektywę znaczeń oraz rozumieć podejmowane przez nich działania.

Jak twierdzi Steinar Kvale, wywiad częściowo ustrukturyzowany posiada scenariusz w postaci zagadnień, ale pozwala na dowolną kolejność zadawanych pytań oraz na pytania dodatkowe w razie potrzeby rozwinięcia wypowiedzi respondenta. Scenariusz wywiadu może ulegać zmianom w trakcie badania na skutek pojawienia się nowych powiązań i refleksji u osoby badanej. Otwarte pytania zakładają skupienie się na pewnych tematach, a nie sztywność struktury wywiadu ${ }^{10}$. Dzięki nim mogłam zrozumieć, czym są działania destabilizujące i jak wpływają na budowanie relacji w rodzinnym domu dziecka.

Drugą techniką, jaką zastosowano w badaniu, była obserwacja. Zdaniem Krzysztofa Koneckiego technika obserwacji pozwala bezpośrednio dotrzeć do epizodów interakcyjnych, zdarzeń, procesów pracy, wypowiedzi o doświadczeniach życiowych ${ }^{11}$. W prowadzonych badaniach w rodzinnym domu dziecka badacz przyjął rolę uczestnika jako obserwatora, starając się nie tylko przebywać często i regularnie z badanymi osobami, ale też uzyskać akceptację i zgodę na obserwację ich życia codziennego. Były to zatem badania o charakterze jawnym, gdzie wiedza o tożsamości badacza-obserwatora była powszechnie dostępna.

${ }^{8}$ M. Angrosino, Badania etnograficzne i obserwacyjne, Wydawnictwo Naukowe PWN, Warszawa 2010, s. 31.

${ }^{9}$ R. Prus, Approaching The Study Of Human Group Life: Symbolic Interaction And Ethnographic Inquiry, [in:] D.M. Lorenz, R. Prus, W. Shaffir (eds.), Ethnography as Human Lived Experience, Copp Clark Longman Ltd., Toronto 1994, s. 21.

${ }^{10}$ S. Kvale, Prowadzenie wywiadów, Wydawnictwo Naukowe PWN, Warszawa 2011, s. 96.

${ }^{11} \mathrm{~K}$. Konecki, Studia z metodologii badań jakościowych. Teoria ugruntowana, Wydawnictwo Naukowe PWN, Warszawa 2000, s. 145. 


\section{Wybrane czynniki zakłócające relacje społeczne w rodzinnym domu dziecka - wyniki badań}

Czynniki zakłócające relacje społeczne w rodzinnym domu dziecka można podzielić na trzy główne kategorie. Pierwsza odnosi się do zachowań agresywnych, jakie przejawiają podopieczni w stosunku do pracowników oraz innych współmieszkańców. W tym wypadku odnotować należy także agresję skierowaną na samego siebie, czyli autoagresję. Druga dotyczy bierności i wycofania podopiecznego z życia placówki. Trzecia odnosi się do postawy roszczeniowej, zwłaszcza wobec pracowników rodzinnego domu dziecka.

\section{Agresja i autoagresja}

Jednym $\mathrm{z}$ istotnych działań podopiecznych rodzinnych domów dziecka, które ma bezpośredni wpływ na przebieg relacji w rodzinnym domu dziecka, jest stopień oraz charakter ich zachowań agresywnych.

W Encyklopedii bioetyki możemy przeczytać, że „agresja (od łac. aggressio - napaść, najazd, natarcie) to każde zamierzone działanie mające na celu wyrządzenie komuś krzywdy lub czemuś szkody, straty, bólu"12. Na gruncie psychologii przez agresję rozumie się „wszelkie działanie (fizyczne lub słowne), którego celem jest wyrządzenie krzywdy fizycznej lub psychicznej - rzeczywistej lub symbolicznej - jakiejś osobie lub czemuś, co ją zastępuje ${ }^{13}$.

Stosując określone podziały, można wyróżnić dwie podstawowe formy agresji: werbalną i fizyczną. Pierwszy rodzaj zachowań agresywnych przeważnie polega na stosowaniu gróźb bądź wulgaryzmów zarówno w stosunku do współmieszkańców, jak i pracowników. Towarzyszy temu odpowiednia, donośna intonacja, podniesiony głos, a w niektórych przypadkach krzyk. Chociaż sytuacje z użyciem agresji słownej przez podopiecznych nie należą do najprzyjemniejszych, to jednak znacznie bardziej niebezpieczna od niej jest agresja fizyczna, która może być skierowana na młodszych podopiecznych, ale też na pracowników placówki. Na pytanie Jakie działania podopiecznych destabilizuja relacje $w$ rodzinnym domu dziecka? badani respondenci odpowiedzieli ${ }^{14}$ :

Mieliśmy dziewczynkę która stosowała przemoc, ona nie chciała rozwiązania żadnego problemu, na wszystko reagowała krzykiem i właśnie agresją, to był krzyk, wrzask, rzucanie meblami, rzucanie rzeczami które miała pod ręką, to była potrzeba wyrzucenia z siebie wszystkiego. Nie potrafiła sama sobie radzić ze swoimi uczuciami, ona nie potrafiła mówić o tym, czego potrzebuje, co chce, co się stało, wszystko kończyło się krzykiem. I w końcu ktoś nam poradził żeby się udać do specjalisty i zbadać małą. I w końcu mi się udało. W momencie kie-

\footnotetext{
12 J. Kalniuk, Encyklopedia bioetyki, Polskie Wydawnictwo Encyklopedyczne, Radom 2007, s. 23.

${ }_{13}$ W. Szewczuk, Stownik psychologiczny, Wiedza Powszechna, Warszawa 1979, s. 15.

${ }^{14} \mathrm{~W}$ cytowanych wypowiedziach respondentów zachowano pisownię oryginalną (przyp. red.).
} 
dy znaleźliśmy wspólny język, to co do niej przemawia, to na czym jej zależy, to dopiero wtedy zaczęłyśmy budować relacje (pracownik, 49 lat, Gdynia).

Mieliśmy chłopca który szedł w kierunku demoralizacji, np. wrócił pod wpływem alkoholu raz czy drugi i teraz inne dzieci myślały sobie, na ile Ciocia zauważyła?, na ile muszę go kryć?, a na ile muszę być fair wobec opiekunów? (pracownik, 54 lata, Gdynia).

Są podopieczni, którzy ignorują polecenia i zasady, arogancko odnoszą się do pracowników, chcąc udowodnić swoją wyższość przed innymi współmieszkańcami (pracownik, 41 lat, Gdańsk).

Dzieci żyły w brutalnym świecie przemocy i były od niej uzależnione. Codziennością było użycie siły fizycznej przez dorosłych wobec dziecka (pracownik, 41 lat, Gdańsk).

Agresja może być skierowana na zewnątrz, jej obiektem staje się wtedy inna osoba, przedmiot lub zjawisko. Może być także kierowana do wewnątrz (autoagresja) wówczas osoba niszczy samą siebie poprzez samokrytykę, samoponiżanie, zaniedbywanie własnych spraw, samookaleczanie, samobójstwo ${ }^{15}$. Na pytanie $W$ jaki sposób przejawia się autoagresja podopiecznych? pracownicy odpowiadają:

Ośmioletni Sylwek, nie umiejąc sobie poradzić z gromadzącymi się w nim emocjami i z nawykiem, że zawsze za wszystko dostaje lanie, sam karał się, uderzając głową o ścianę lub wieszając się za ręce w pokoiku na parapecie, wisiał aż ciekły mu łzy, żeby dotrzeć do stanu błogości (pracownik, 41 lat, Gdańsk).

[...] dziewczynka cięła się od kilku lat, całe ręce miała pocięte i napędzała ją do tego jej ulubiona lektura My dzieci $z$ dworca ZOO. Po paru latach wspólnego mieszkania przestała się ciąć, ale po każdym chłopaku, z którym się rozstawała musiała pozostawić ślad nienawiści na swoim ciele np. samodzielnie wykonany tatuaż lub kilkunasty kolczyk (pracownik, 41 lat, Gdańsk).

Agresja wychowanka może wskazywać pracownikom jego aktualną sytuację. Podopieczny może bowiem nie być w stanie zakomunikować otoczeniu, co się z nim dzieje, a dana forma agresywnych i autoagresywnych zachowań jest reakcją na określoną dokuczliwą dolegliwość. Są to przeważnie zachowania nieświadome, które niosą ze sobą określoną informację, będąc rodzajem nieintencjonalnego komunikatu podopiecznego.

Inny rodzaj agresji i autoagresji to agresja świadoma, będąca wynikiem intencjonalnych działań podopiecznego. Na przykład podopieczny jest zazdrosny o względy okazywane przez opiekuna innemu podopiecznemu. Podobnie jak w przypadku agresji wywoływanej nieświadomie i bez intencji wychowanka, także tutaj zadaniem

15 A. Frączek, O naturze i formowaniu się psychologicznej regulacji agresji interpersonalnej, [w:] I. Kurcz, D. Kądzielewa (red.), Psychologia czynności. Nowe perspektywy, Wydawnictwo Naukowe „Scholar”, Warszawa 2001, s. 45-64. 
pracowników jest „czytanie między słowami”, czyli uchwycenie i poprawne zinterpretowanie symbolicznego znaczenia agresji podopiecznego.

Niezależnie jednak od okoliczności przyczyn oraz rodzaju agresji zadaniem pracowników jest unikanie tego typu sytuacji. Pracownicy powinni eliminować wszelkie ewentualne bodźce z otoczenia podopiecznego, które mogą wywołać agresję, oraz poprawnie interpretować wszelkie sygnały, które mogą być wskaźnikiem wystąpienia agresji. Pracownik niestety nie zawsze jest w stanie w porę zapobiec tego rodzaju aktywności podopiecznego, dlatego jego działania powinny być również skoncentrowane na minimalizowaniu skutków zaistniałych już aktów agresji. Na pytanie Jakie działania podejmuja pracownicy, żeby przeciwdziałać zachowaniom agresywnym podopiecznych? pracownicy podali wiele odpowiedzi. Były wśród nich takie propozycje działań, jak rozmowa i przypominanie o zasadach panujących w placówce oraz odizolowanie podopiecznego. Oto przykłady:

Był chłopak, który poczuł się dorosły i uważał, że może używać sobie wulgaryzmów w domu. No więc przypominamy mu, że takich zachowań w domu u nas nie ma. Ja z mężem nie odzywamy się do nikogo w ten sposób, staramy się nie krzyczeć i nie denerwować, nie podejmować decyzji w złości i uczymy tego też dzieci i staramy się tego od nich wymagać. Z różnym efektem i skutkiem (pracownik, 49 lat, Gdynia).

Zdarzały się takie sytuacje, gdy dzieci miały tendencje do agresji, to np. kazaliśmy iść do swojego pokoju i były odizolowane, a były takie izolacje pod nadzorem - czyli siedzieliśmy w pokoju i obserwowaliśmy, w jaki sposób to wyładowanie złych emocji następuje. Jak się to rozwija? (pracownik, 49 lat, Gdynia).

Bez względu na rodzaj i charakter agresja zawsze niesie ze sobą określone konsekwencje i dla podopiecznych, i dla pracowników. Każdy przejaw i rodzaj agresji może skończyć się uszczerbkiem na zdrowiu psychicznym i fizycznym podopiecznych. Należy jednak pamiętać, że może także prowadzić do zachwiania równowagi psychicznej opiekunów, a nawet degradacji poczucia profesjonalizmu, wywołując tym samym kryzys czy wypalenie zawodowe. Wszystkie te zjawiska mogą z kolei powodować zakłócenia w funkcjonowaniu życia rodzinnego, niekorzystnie wpływając na stan zdrowia opiekunów oraz kondycję relacji społecznych. Wniosek ten potwierdza poniższa wypowiedź:

Był moment takiego zastanowienia się nad sensem pracy, mieliśmy trudne doświadczenia i w takich trudnych doświadczeniach czasami przychodzi refleksja, czy to ma wszystko sens? Czy to co ja robię ma sens? Czy może w ogóle ta moja praca nie ma sensu i w ogóle lepiej byłoby zrezygnować... Ale takie chwile chyba ma każdy z nas w trudnym momencie (pracownik, 49 lat, Gdynia).

Relacjom pracowników z podopiecznymi rodzinnego domu dziecka zagrażają, oprócz przejawów agresji, także zgoła odmienne czynniki, wynikające z niechęci do aktywności podopiecznych. Należą do nich bierność, wycofanie, niesamodzielność oraz roszczeniowość podopiecznych. 


\section{Bierność i wycofanie}

Innym czynnikiem zaburzającym relacje społeczne w rodzinnym domu dziecka jest zaniechanie działań, czyli bierność i wycofanie się podopiecznych. Bierność definiuje się jako apatię podopiecznego oraz niechęć do podejmowania jakichkolwiek form aktywności. Wycofanie podopiecznych rodzinnych domów dziecka rozumiane jest natomiast jako brak zainteresowania własną osobą, własnym losem oraz przyszłością. To niepodejmowanie refleksji nad swoją obecną i przyszłą sytuacją ${ }^{16}$. Bierność ujawnia się także w wymiarze interpersonalnym, to jest w niechęci do kontaktów $z$ otoczeniem i brakiem reakcji na bodźce pochodzące z zewnątrz. Wycofanie wychowanka dotyczy zaś jego świadomego, całkowitego bądź częściowego odosobnienia i niechęci do nawiązywania oraz podtrzymywania bliższych więzi z innymi osobami. Egzemplifikacją powyższej analizy są wybrane fragmenty wypowiedzi badanych.

U nas całe życie przewija się przez salon, jeśli ktoś nie chcę zejść do nas i siedzi w swoim pokoju, izoluje się od reszty, to jest to dla nas sygnał, że dzieje się coś niedobrego (pracownik, 49 lat, Gdynia).

Niektóre dzieci są wyjątkowo antyspołeczne, co wynika z zaburzeń i posiadanych jednostek chorobowych. Należy wyważyć, kiedy wyjście zespołowe będzie progresywne dla dziecka, a kiedy jeszcze bardziej może mu przypomnieć jego wczesnodziecięce traumy. W skrajnych przypadkach dzieci korzystają z terapii specjalistycznych (pracownik, 39 lat, Gdańsk).

Bierność i wycofanie są zjawiskami, które w warunkach rodzinnych domów dziecka powodują konieczność wzmożonego zaangażowania i pracy opiekunów. Są one bowiem źródłem określonych obowiązków, jakie ma do wypełnienia pracownik. W ten sposób, zgodnie $z$ oficjalną interpretacją, wszelkie formy aktywizowania podopiecznych mają na celu przeciwdziałanie negatywnym konsekwencjom postawy bierności podopiecznych. Na pytanie Jakie działania podejmuja pracownicy, żeby przeciwdziałać bierności i wycofaniu podopiecznych? badani respondenci odpowiedzieli:

Angażujemy dziecko, staramy się dotrzeć, dlaczego tak się dzieje, dlaczego się wycofuje, bo może to jest jakaś jednostka chorobowa i trzeba jakieś stymulacje robić czy szukać specjalisty, czy np. wynika z tego, że nie lubię tego robić i skoro nie lubi tego robić, to na pewno lubi robić coś innego. Zawsze staramy się znaleźć źródło wycofania (pracownik, 49 lat, Gdynia).

Jak twierdzą opiekunowie, fizyczna i umysłowa stagnacja prowadzi bowiem do apatii wychowanka, utrudniając relacje społeczne, do stopniowego procesu uzależnienia od placówki oraz przeniesienia ciężaru odpowiedzialności za własne życia na inne osoby. Chociaż pracownicy podejmują starania na rzecz aktywizowania pod-

${ }^{16}$ K. Przełowiecka, Zjawisko wyuczonej bezradności u klientów instytucji pomocy społecznej przyczyny, konsekwencje, możliwości przeciwdziałania, [w:] M Piorunek (red.), Pomoc - wsparcie społeczne poradnictwo. Od teorii do praktyki, Wydawnictwo Adam Marszałek, Toruń 2010, s. 204. 
opiecznych, to czynią to jednak w sposób sobie właściwy, zgodny z własnymi potrzebami i interpretacjami.

\section{Postawa roszczeniowa}

Z biernością i wycofaniem związana jest roszczeniowość podopiecznych rodzinnych domów dziecka. Pomiędzy tymi kategoriami istnieje określone powiązanie. Otóż, im większe jest przyzwolenie pracowników na postawę roszczeniową podopiecznych, tym w większym stopniu uwidacznia się bierność wychowanków. Pracownicy, realizując różne czynności związane z opieką nad podopiecznym, powodują, iż skala oczekiwań podopiecznych wzrasta, przy jednoczesnym obniżeniu chęci do samodzielnego działania. Wniosek ten potwierdza poniższa wypowiedź:

Są takie rzeczy, że dzieci wiedzą, że im się należy, natomiast staraliśmy się w dzieciach wyprzeć podejście roszczeniowe. Kiedy przychodzi sponsor, to nie jest na zasadzie, że mi się to należy, ja przyjmuję dar, ale muszę podziękować, zrobić jakąś laurkę. A nie na zasadzie, że jestem biedny Bartuś i nikt mnie nie kocha i chce to! Staramy się ich uczyć, że niekoniecznie wszystko mi się w życiu należy (pracownik, 49 lat, Gdynia).

Zważając na charakterystykę rodzinnych domów dziecka, należy wyjaśnić, czym jest roszczeniowość podopiecznych placówki rodzinnej, a także jaka jest jej specyfika. Trzeba zaznaczyć, że formalne wymagania stawiane są przede wszystkim pracownikom rodzinnych domów dziecka. Taka sytuacja sprawia, że roszczeniowość podopiecznych skierowana jest w szczególności wobec pracowników i to w stosunku do nich jest najwięcej oczekiwań. W pewnym zakresie wynika to z faktu, że pracownicy ulegają podopiecznym i wywoływanym przez nich emocjom. Oto przykład:

Ta dziewczynka nie była całkiem roszczeniowa, bo ona była od matki, która stosowała przemoc i dużo przeszła, ona żyła ciągle w ogromnym napięciu i stresie (pracownik, 49 lat, Malbork).

Roszczeniowość może się objawiać w wielu obszarach życia i dotyczyć różnych jego sfer. Na pytanie W jakich sytuacjach ujawnia się roszczeniowa postawa podopiecznych? badani odpowiedzieli:

Podopieczni często dostrzegają niesprawiedliwości tego świata, które najczęściej uderzają konkretnie w ich osoby. Wysoki negatywizm, który prezentują, skłania do roszczeniowej postawy. Jeżeli któryś z podopiecznych ma taką osobowość, to przeszkadza mu prawie wszystko: „nie ten kubek, on ma lepsze, nikt mnie nie rozumie, żądam rozmowy, mam to gdzieś, nie zależy mi” itp. Opiekun stara się wskazać pozytywne aspekty codzienności, jednak podopieczny musi okazać przekonanie i chęć do współpracy (pracownik, 39 lat, Gdańsk).

Podsumowując, postawa roszczeniowa ujawnia się w różnych postaciach, od egoizmu podopiecznego począwszy, poprzez interesowność, a na swoistym okazywaniu niezadowolenia skończywszy. I tak na przykład egoizm podopiecznych objawia się między innymi skupieniem uwagi na własnej osobie oraz zupełnym brakiem zain- 
teresowania sytuacją współmieszkańców. Interesowność dotyczy natomiast sytuacji, w których podopieczni wykazują aktywność oraz gotowość zrobienia czegoś pod warunkiem, że zostanie im zaoferowana jakaś wymierna korzyść. Przejawia się też jako świadome wykorzystywanie emocjonalności pracowników (tzw. przymilanie się), które wynika z chęci pozyskania określonych rzeczy i zaspokojenia swoich potrzeb.

\section{Zakończenie}

Zasadniczym celem artykułu było przedstawienie problematyki znaczenia działań podopiecznych na destabilizację relacji w rodzinnym domu dziecka. Z tego względu głównym zadaniem było poszukanie odpowiedzi na pytanie: Jakie działania podopiecznych destabilizują relację w rodzinnym domu dziecka? Na podstawie przeprowadzonych analiz udało się ustalić kilka wniosków, co starałam się wykazać poniżej.

Relacje pracowników z podopiecznymi rodzinnych domów dziecka są w ciągłym i dynamicznym procesie zmian, co wiąże się z niepewnością pracownika co do zachowań podopiecznych. Atmosfera, w której zachodzą relacje między partnerami, może charakteryzować się skrajnościami - od przesadnej aktywności, w tym agresji i autoagresji, do zupełnej bierności i wycofania, a także wytworzenia postawy roszczeniowej wobec pracowników. To z kolei skutkuje wykształceniem się postawy zdystansowania hamującej rozwój relacji partnerskich.

\section{Bibliografia}

Angrosino M., Badania etnograficzne i obserwacyjne, Wydawnictwo Naukowe PWN, Warszawa 2010.

Cicirelli V.G., Sibling relationships throughout the life cycle, [in:] L. Abate (ed.), The handbook of family psychology and therapy, Vol. 95(1), Dorsey Press, Homewood 1985.

Drabik L., Sobol E., Słownik języka polskiego PWN, Wydawnictwo Naukowe PWN, Warszawa 2018.

Frączek A., O naturze i formowaniu się psychologicznej regulacji agresji interpersonalnej, [w:] I. Kurcz, D. Kądzielewa (red.), Psychologia czynności. Nowe perspektywy, Wydawnictwo Naukowe „Scholar”, Warszawa 2001.

Goode W.J., Family Disorganization, [in:] R.K. Merton, R.A. Nisbet (eds.), Contemporary Social Problems: An Introduction to the Sociology of Deviant Behavior and Social Disorganization, Harcourt, Brace \& World, New York 1961, s. 390-458, za: M. Piorunek, J. Kozielewska, A. Skowrońska-Pućka, Rodzina. Młodzież. Dziecko. Szkice z teorii i praktyki pomocy psychopedagogicznej i socjalnej, [w:] 
M. Grześko-Nyczka (red.), Istota i przejawy społecznego problemu dezorganizacji rodziny w Polsce po 1989 r., Wydawnictwo Naukowe, Poznań 2003.

Kalniuk J., Encyklopedia bioetyki, Polskie Wydawnictwo Encyklopedyczne, Radom 2007.

Kawula S., Człowiek w relacjach socjopedagogicznych, Wydawnictwo Edukacyjne Akapit, Toruń 1999.

Kiecolt-Glaser J.K., Glaser R., Stress and immune function in humans, [in:] R. Adler, D.L. Felten, N. Cohnen (eds.), Psychoneuroimmunology, Academic Press, New York 1991.

Konecki K., Studia z metodologii badań jakościowych. Teoria ugruntowana, Wydawnictwo Naukowe PWN, Warszawa 2000.

Kvale S., Prowadzenie wywiadów, Wydawnictwo Naukowe PWN, Warszawa 2011.

Prus R., Approaching The Study of Human Group Life: Symbolic Interaction and Ethnographic Inquiry, [in:] D.M. Lorenz, R. Prus, W. Shaffir (eds.), Ethnography as Human Lived Experience, Copp Clark Longman Ltd., Toronto 1994.

Przełowiecka K., Zjawisko wyuczonej bezradności u klientów instytucji pomocy społecznej - przyczyny, konsekwencje, możliwości przeciwdziałania, [w:] M Piorunek (red.), Pomoc - wsparcie - społeczne poradnictwo. Od teorii do praktyki, Wydawnictwo Adam Marszałek, Toruń 2010.

Szewczuk W., Słownik psychologiczny, Wiedza Powszechna, Warszawa 1979.

Tyszkowa M., Psychologia rozwoju człowieka. T. 1, Wydawnictwo Naukowe PWN, Warszawa 1996.

\section{Akty prawne}

Rozporządzenie Ministra Pracy i Polityki Społecznej z 14 lutego 2005 r. w sprawie placówek opiekuńczo-wychowawczych, Dz.U. 2005, nr 37, poz. 331.

Ustawa z dnia 12 marca 2004 r. o pomocy społecznej, Dz.U. 2004, nr 64, poz. 593.

\section{Actions of foster children destabilising relationships in the family foster home}

Abstract: The article describes the actions of foster children that destabilise relationships in foster family homes. The article presents the variability of relationships in foster family homes and discusses the results of ethnographic research. The analysis shows dependencies between the activities of foster children, carers and others in foster family homes. The article presents disturbing behaviours in relationships in foster family homes such as: aggression and auto-aggression, passivity and withdrawal, as well as a demanding attitude.

Keywords: destabilising actions, social relations, family foster homes

About the author: Agnieszka Deja - PhD student of pedagogy, Social Sciences Faculty, University of Gdańsk. Bachelor: pedagogical care and pedagogy with pedagogical therapy. Masters: social pedagogy. Interests: substitute care, family forms of foster care, family foster home, symbolic interactionism. 
Dorota Pufund* (iD) https://orcid.org/0000-0003-0439-0723

Uniwersytet Kazimierza Wielkiego w Bydgoszczy

https://doi.org/10.25312/2083-2923.16/2019_04dp

\title{
"Zrozumieć niepojęte" - specyfika odbioru i przetwarzania bodźców sensorycznych u dzieci ze spektrum autyzmu
}

\begin{abstract}
Streszczenie: Artykuł przybliża problematykę nietypowego funkcjonowania sensorycznego dzieci ze spektrum autyzmu. Redefinicja autyzmu zawarta w Klasyfikacji zaburzeń psychicznych Amerykańskiego Towarzystwa Psychiatrycznego DSM-5, włączenie do kryteriów diagnostycznych hiper- lub hiporeaktywności, stanowi uzasadnienie przyjęcia sensorycznej perspektywy w procesie wieloprofilowej diagnozy dziecka oraz planowaniu oddziaływań tak edukacyjnych, jak i terapeutycznych. Artykuł stanowi próbę rekonstrukcji teorii integracji sensorycznej według Jean A. Ayres oraz ukazania w jej świetle trudności sensorycznych, z którymi borykają się dzieci ze spektrum autyzmu. W tym celu przybliżono typologię zaburzeń przetwarzania sensorycznego Lucy Jane Miller oraz Winnie Dunn. Specyficzny odbiór wyrażeń zmysłowych zakłóca lub niekiedy uniemożliwia uczestnictwo w życiu przedszkola czy szkoły, utrudnia uczenie się, dlatego tak ważne jest eliminowanie sensorycznych barier oraz kształtowanie przyjaznego sensorycznie środowiska. W artykule zwrócono uwagę na konieczność uwzględnienia sensorycznych potrzeb dzieci ze spektrum autyzmu w procesie organizacji ich kształcenia oraz terapii jako jednego z istotnych czynników warunkujących ich rozwój psychoruchowy i społeczno-emocjonalny. Omówiono także implikacje praktyczne.
\end{abstract}

Słowa kluczowe: autystyczne spektrum zaburzeń, zaburzenia przetwarzania sensorycznego

* Dorota Pufund - doktorantka pedagogiki na Uniwersytecie Kazimierza Wielkiego w Bydgoszczy, oligofrenopedagog, surdopedagog, tyflopedagog, terapeuta pedagogiczny, terapeuta integracji sensorycznej (członek PSTIS), filolog polski, pedagog przedszkolny i wczesnoszkolny. Pracuje jako pedagog w Poradni Psychologiczno-Pedagogicznej nr 2 w Bydgoszczy, gdzie zajmuje się diagnozą i terapią dzieci, wspieraniem rodziców oraz nauczycieli. Zainteresowania naukowe: specjalne potrzeby edukacyjne, diagnoza i terapia dziecka, zaburzenia ze spektrum autyzmu, zaburzenia przetwarzania sensorycznego. 


\section{Wprowadzenie}

„Zrozumieć niepojęte” - to niezwykle trudne, aczkolwiek wciąż aktualne wyzwanie, będące peryfrazą tytułu monografii Carla Delacato ${ }^{1}$, a także jednym z najbardziej rozpoznawalnych dzieł podnoszących kwestię funkcjonowania sensorycznego osób ze spektrum autyzmu, od lat towarzyszy zarówno badaczom, jak i pedagogom w codziennych zmaganiach w praktyce edukacyjnej i terapeutycznej. Specyficzny odbiór wyrażeń zmysłowych zakłóca lub niekiedy wręcz uniemożliwia uczestnictwo w życiu przedszkola czy szkoły, utrudnia uczenie się, nawiązywanie satysfakcjonujących relacji rówieśniczych, dlatego tak ważne jest eliminowanie sensorycznych barier oraz kształtowanie przyjaznego sensorycznie środowiska. Od chwili opisania przez Leo Kannera w 1943 roku zaburzenie autystyczne z uwagi na swoją złożoność i niejednorodność było przedmiotem zainteresowania wielu badaczy. Rosła nie tylko świadomość występowania autyzmu, ale także specyfiki odbioru i przetwarzania bodźców sensorycznych ${ }^{2}$. Redefinicja autyzmu zawarta w Klasyfikacji zaburzeń psychicznych Amerykańskiego Towarzystwa Psychiatrycznego DSM-5³ - włączenie do kryteriów diagnostycznych hiper- lub hiporeaktywności, stanowi uzasadnienie przyjęcia sensorycznej perspektywy w procesie wieloprofilowej diagnozy dziecka oraz planowaniu oddziaływań tak edukacyjnych, jak i terapeutycznych. O „alternatywnej rzeczywistości sensorycznej" ${ }^{4}$ dowiadujemy się także z autobiograficznych relacji osób ze spektrum autyzmu. Wspomnienia Temple Grandin (Mózg autystyczny), Donny Williams (Nikt nigdzie), Naokiego Higashida (Dlaczego podskakuję), Dietmara Zöllera (Gdybym mógł z wami rozmawiać) oraz wielu innych samorzeczników pozwalają spojrzeć na rzeczywistość sensoryczną z innej perspektywy oraz zrozumieć, jak indywidualny, zróżnicowany i wielowymiarowy jest autyzm. Jako diagnosta i terapeuta integracji sensorycznej chciałabym zaprezentować metodę integracji sensorycznej ${ }^{5}$

${ }^{1}$ C. Delacato, Dziwne, niepojęte. Autystyczne dziecko, Fundacja Synapsis, Warszawa 1995.

2 Warto w tym miejscu wymienić za O. Bogdashiną prace takich badaczy jak: Escalone, 1948; Ornitz, 1969, 1974; Delacato, 1974; Volkmar, Cohen i in., 1986; Wing, 1972; Astderau i in., 2013; Lane, Molloy, Bishop. O. Bogdashina, Sensory perceptual issues in autism and Asperger syndrome. Different Sensory Experiences - Different Perceptual Words, Jessica Kingsley Publishers, London 2016, s. 25-29. Wśród polskich badań podnoszących specyfikę przetwarzania sensorycznego dzieci ze spektrum autyzmu wymienić należy dysertacje doktorską Marty Wiśniewskiej Profile sensoryczne dzieci z zaburzeniami rozwojowymi w wieku 3-10 lat - diagnoza i wskazania do terapii (Akademia Pedagogiki Specjalnej) oraz Zuzanny Domasiewicz Specyfika odbioru i przetwarzania bodźców sensorycznych a nasilenie zburzeń rozwoju dzieci z autyzmem (Uniwersytet Warszawski).

${ }^{3}$ P. Gałecki i in. (red.), Kryteria diagnostyczne zaburzeń psychicznych DSM-5, Edra Urban \& Partner, Wrocław 2018.

${ }^{4}$ Określenie zostało ukute przez Temple Grandin - profesor zootechniki na Uniwersytecie Colorado, dorosłej kobiety z autyzmem, autorki wielu książek na temat funkcjonowania osób ze spektrum autyzmu. T. Grandin, Mózg autystyczny. Podróż w głąb niezwykłych umysłów, Copernicus Center Press, Kraków 2018, s. 107.

${ }^{5}$ Metoda integracji sensorycznej trafiła do Polski w 1993 roku, wówczas odbył się pierwszy kurs integracji sensorycznej w Polsce. 
Jean A. Ayres jako jedną z możliwych odpowiedzi na specyficzny odbiór bodźców zmysłowych u dzieci ze spektrum autyzmu.

\section{Integracja sensoryczna - podstawy teoretyczne}

Termin integracja sensoryczna został po raz pierwszy użyty przez neurofizjologa Charles'a Sherringtona w 1902 roku$^{6}$. Jednak to dzięki pionierskim hipotezom sformułowanym w latach sześćdziesiątych XX wieku przez amerykańską badaczkę Ayres (1920-1988) trafił on na stałe do słownika terapeutów, pedagogów specjalnych, nauczycieli pracujących z osobami o nietypowym rozwoju. Badaczka - psycholog, terapeuta zajęciowy, pracownik Uniwersytetu Kalifornijskiego w Stanach Zjednoczonych, korzystając z dorobku psychologii, neurofizjologii systemów zmysłowych oraz neurobiologii, ukazała związek między nietypowym odbiorem bodźców zmysłowych a procesami uczenia się ${ }^{7}$. Początkowo metoda znajdowała zastosowanie wobec uczniów o specyficznych trudnościach w nauce, $\mathrm{z}$ czasem zaś poszerzyła swoje grono odbiorców także o dzieci z nietypowym czy zaburzonym rozwojem. Ayres jest autorką zarówno teoretycznych podstaw metody integracji sensorycznej, jak i kompleksowej metody terapii oraz diagnozy, a jej dorobek jest kontynuowany przez badaczy na całym świecie.

Integracja sensoryczna jest zagadnieniem wielowymiarowym, odnosi się bowiem do rozwoju psychoruchowego, społeczno-emocjonalnego, nauki szkolnej, zachowania oraz zdolności do samoregulacji. Stownik pedagogiki specjalnej wskazuje, iż jest to:

proces celowej organizacji informacji docierających do mózgu ze wszystkich zmysłów (wzroku, dotyku, układu proprioceptywnego, kinestezji, równowagi, słuchu, powonienia oraz smaku), polegający na rozpoznaniu, segregacji, interpretacji i unifikacji tych informacji, umożliwiający adekwatną reakcję i celowe działanie, stanowiąc odpowiedź adaptacyjną na wymagania płynące z otoczeniå

Integracja sensoryczna jest procesem interakcji i koordynacji dwóch lub więcej funkcji, gdzie odbierane informacje sensoryczne są organizowane i interpretowane, tak by możliwe było opracowanie efektywnej odpowiedzi behawioralnej. Jest to wejście w stan, który Ayres nazywa „stanem samoutrwalającej się równowagi”"

${ }^{6}$ V. Maas, Uczenie się przez zmysty, Harmonia, Gdańsk 2016, s. 18.

7 Zob. J. Ayres, Integracja sensoryczna a zaburzenia uczenia się, Harmonia, Warszawa 2018, s. 13-17; M. Wiśniewska, Profil Sensoryczny Dziecka (PSD) - model diagnozy profilu sensorycznego dzieci z zaburzeniami w rozwoju, Pracownia Testów Psychologicznych i Pedagogicznych, Gdańsk 2014, s. 16; Z. Przyrowski, Integracja sensoryczna. Wprowadzenie do teorii, diagnozy i terapii, Empis, Warszawa 2012, s. 13; V. Maas, Integracja sensoryczna a neuronauka - od narodzin do starości, Fundacja Innowacja, Warszawa 2007, s. 155-158; V. Maas, dz. cyt., s. 23.

${ }^{8}$ M. Kupisiewcz, Integracja sensoryczna, [w:] tegoż, Słownik pedagogiki specjalnej, Wydawnictwo Naukowe PWN, Warszawa 2014, s. 138.

9 J. Ayres, dz. cyt., s. 46. 
Integracja sensoryczna jest planowaną, chociaż niedyrektywną organizacją stymulacji zmysłowej, przy aktywnym udziale dziecka. W czasie terapii dziecko nie uczy się konkretnych umiejętności. Doskonalące się procesy integracji sensorycznej w mózgu tworzą warunki do ich nabywania.

Do zrozumienia założeń metody integracji sensorycznej według Ayres konieczna jest rekonstrukcja jej założeń teoretycznych. Badaczka oparła swoją teorię na następujących konstruktach: koncepcji plastyczności i integralności układu nerwowego oraz sekwencyjności rozwoju procesów integracji sensorycznej.

Termin plastyczność neuronalna został wprowadzony przez polskiego uczonego Jerzego Konorskiego. Pod tym pojęciem kryje się proces pozwalający na dokonywanie modyfikacji i zmian w obrębie układu nerwowego. Reorganizacja połączeń synaptycznych jest możliwa dzięki rozgałęzianiu i rozrastaniu się aksonów - tzw. sprouting, wytracaniu niepotrzebnych połączeń neuronalnych oraz dzięki procesom kompensacyjnym i restytucyjnym. Plastyczność jest procesem uniwersalnym, który trwa przez całe życie, choć intensyfikacja zmian może być różna w poszczególnych etapach życia ${ }^{10}$. Jak konstatuje Ayres, plastyczność jest wrodzonym mechanizmem „zdolnością mózgu do zmiany” - który pozwala rozwijać lub wzmacniać procesy umożliwiające skuteczne działanie i współdziałanie z otoczeniem. Dynamika rozwoju jest zależna między innymi od doświadczeń czuciowo-ruchowych, które pozwalają na modyfikacje w obrębie wszystkich poziomów układu nerwowego ${ }^{11}$.

Integracja sensoryczna jest przez wielu potocznie nazywana formą naukowej zabawy, gdyż w procesach integracyjnych kluczową rolę odgrywa motywacja i zaangażowanie się dziecka. W tym miejscu należy odróżnić bierną stymulację zmysłową od terapii metodą integracji sensorycznej. Aktywne uczestnictwo dziecka jest warunkiem efektywnego przebiegu działań terapeutycznych. W metodzie integracji sensorycznej podkreśla się rolę wewnętrznego pędu rozwoju, który Carol Kranovitz określa metaforycznie „apetytem na pokarm sensoryczny” ${ }^{12}$. Nie byłoby to możliwe bez uwzględnienia krytycznych momentów rozwoju dziecka oraz właściwie zaadaptowanego, przyjaznego i zróżnicowanego - przez co atrakcyjnego sensorycznie środowiska.

Kolejnym założeniem teoretycznym modelu integracji sensorycznej według Ayres jest integralność układu nerwowego. Odnosi się ona do wzajemnych, nierozerwalnych zależności między niższymi i wyższymi strukturami mózgu. Ośrodki korowe i podkorowe współpracują ze sobą na zasadzie sprzężenia zwrotnego. Oznacza to, iż funkcjonowanie wyższych struktur - korowych, jest zależne od funkcjonowania niższych - podkorowych. To właśnie w strukturach podkorowych zachodzą podstawo-

${ }^{10}$ M. Borkowska, Integracja sensoryczna w rozwoju dziecka. Podstawy neurofizjologiczne, Harmonia, Gdańsk 2018, s. 139-196.

${ }^{11}$ J. Ayres, dz. cyt., s. 33-38, 60-61.

${ }^{12}$ C. Kranovitz, Nie-zgrane dziecko. Zaburzenia przetwarzania sensorycznego - diagnoza i postępowanie, Harmonia, Gdańsk 2012, s. 77. 
we procesy integracji zmysłowej, natomiast ich pracę warunkują determinanty płynące z warstw korowych. Integralność oraz hierarchiczność mózgu pozwoliła Ayres na osadzenie metody w przekonaniu, iż właściwa stymulacja struktur podkorowych umożliwia doskonalenie pracy mózgu, tworzenie podatnego gruntu dla procesów uczenia się ${ }^{13}$.

Sekwencyjność procesów integracji sensorycznej stanowi kolejny, podstawowy konstrukt teoretyczny metody. Ayres wyróżniła cztery poziomy procesów integracji sensorycznej będące odzwierciedleniem poszczególnych kamieni milowych rozwoju. Co warto podkreślić, badaczka nie wyodrębniła cezur czasowych między poszczególnymi poziomami. Na kanwie już osiągniętych umiejętności wyrastają kolejne, coraz bardziej złożone funkcje percepcyjno-motoryczne.

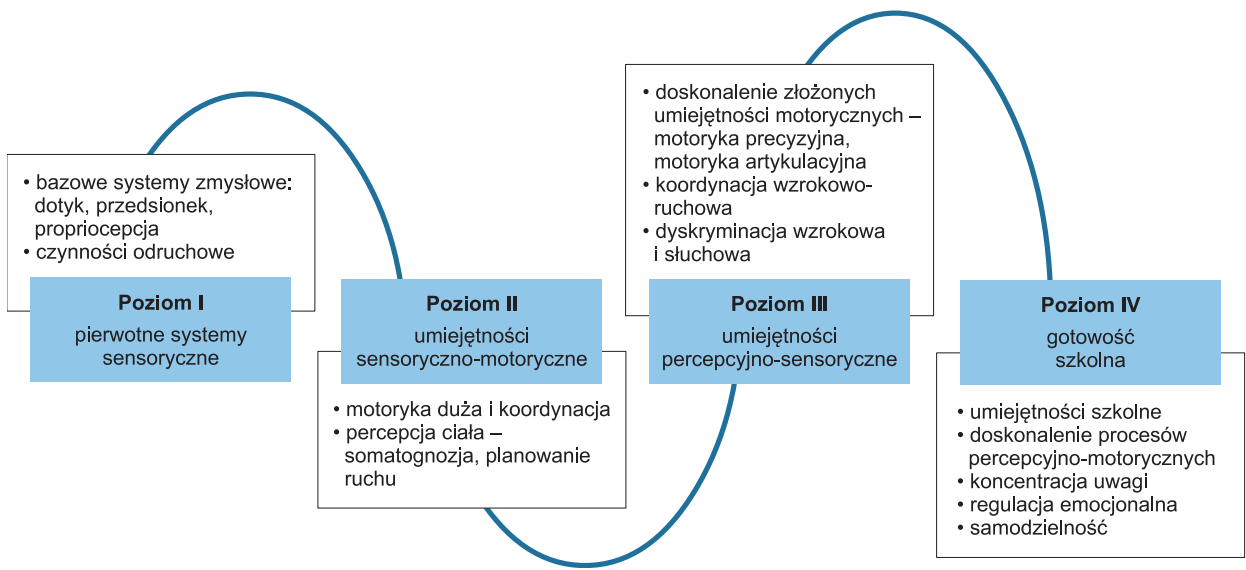

Rys. 1. Poziomu procesów integracji sensorycznej

Źródło: opracowanie własne na podstawie M. Wiśniewska, Profil Sensoryczny Dziecka (PSD) - model diagnozy profilu sensorycznego dzieci z zaburzeniami w rozwoju, Pracownia Testów Psychologicznych i Pedagogicznych, Gdańsk 2014, s. 26-28; C. Kranovitz, Nie-zgrane dziecko. Zaburzenia przetwarzania sensorycznego-diagnoza i postępowanie, Harmonia, Gdańsk 2012, s. 75-76.

\section{Zaburzenia przetwarzania sensorycznego}

Interesująca - nie tylko pod względem poznawczym, ale także w perspektywie praktyki edukacyjnej - jest typologia zaburzeń przetwarzania sensorycznego. W tym kontekście omówione zostaną różnorodne zachowania dzieci ze spektrum autyzmu.

Klasyfikacja zaburzeń przetwarzania sensorycznego zaproponowana przez Lucy Jane Miller - amerykańską terapeutkę i badaczkę związaną między innymi z Uniwersytetem Kolorado w Denver oraz ośrodkiem STAR - Sensory Therapies and Research, kontynuatorkę prac Ayres, jest próbą unifikacji terminologii i uporządkowania nieści-

${ }^{13}$ Z. Przyrowski, dz. cyt., s. 45-46. 
słości, pojęciowego chaosu zarówno wokół samej metody, jak i badań prowadzonych nad jej skutecznością, ale przede wszystkim wprowadzenia przetwarzania sensorycznego jako prawomocnej jednostki diagnostycznej. Zaburzenia przetwarzania sensorycznego ( $\mathrm{z}$ ang. sensory processing disorder - SPD) nie zostały włączone do DSM- $5^{14}$, nie są także ujęte w obowiązującej w Polsce Międzynarodowej Statystycznej Klasyfikacji Chorób i Problemów Zdrowotnych ICD-10 ${ }^{15}$ ani wprowadzanej ICD-11 ${ }^{16}$. Jednostka ta jako „Zaburzenia regulacji związane z przetwarzaniem bodźców sensorycznych" figuruje w Klasyfikacji diagnostycznej zaburzeń psychicznych i rozwojowych w okresie niemowlęctwa $i$ wczesnego dzieciństwa DC:0-3R ${ }^{17}$.

Wyłonioną przez Miller klasyfikację zaburzeń przetwarzania sensorycznego przedstawia rysunek 2 .

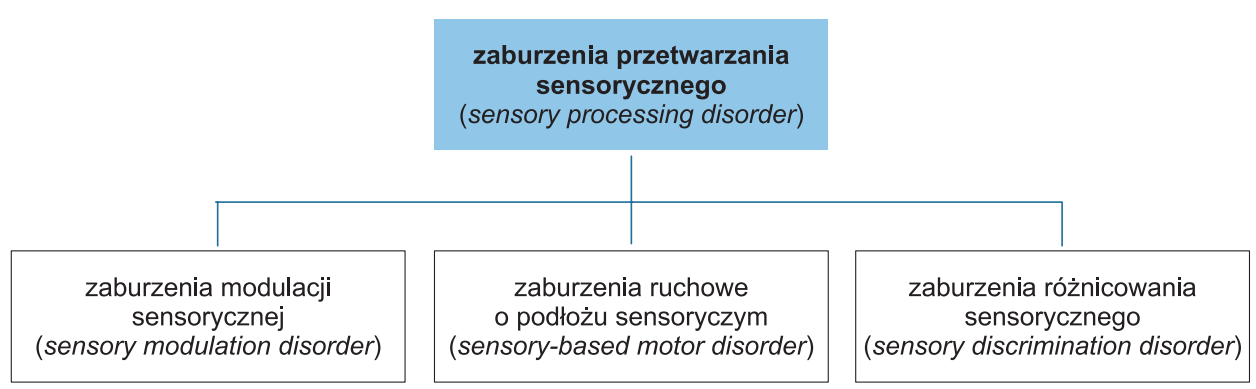

Rys. 2. Klasyfikacja zaburzeń przetwarzania sensorycznego według L. Miller

Źródło: L. Miller, Dzieci w świecie doznań. Jak pomóc dzieciom z zaburzeniami przetwarzania sensorycznego?, Harmonia, Gdańsk 2016, s. 50-51.

Wyłonione przez Miller typy zaburzeń przetwarzania sensorycznego mogą dotyczyć jednego, kilku, a nawet wszystkich systemów zmysłowych oraz współwystępować w dowolnych konfiguracjach, co ukazuje, jak zróżnicowanym i wielowymiarowym procesem jest przetwarzanie sensoryczne.

Modulacja polega na autoregulacji układu nerwowego, oparta jest na procesach wzmacniania bądź hamowania aktywności neuronalnej, tak by utrzymać odpowiedni poziom pobudzenia oraz stan homeostazy ${ }^{18}$. Zaburzenia modulacji sensorycznej dzie-

${ }^{14}$ P. Gałecki i in., dz. cyt.

${ }^{15}$ Międzynarodowa Statystyczna Klasyfikacja Chorób i Problemów Zdrowotnych - X Rewizja, Tom II, wydanie 2008.

${ }^{16}$ International Classification of Diseases, 11th Revision, https://icd.who.int/en [dostęp: 28.10.2019].

${ }^{17}$ Klasyfikacja diagnostyczna DC:0-3R. Klasyfikacja diagnostyczna zaburzeń psychicznych i rozwojowych w okresie niemowlęctwa i wczesnego dzieciństwa, Oficyna Wydawnicza „Fundament”, Warszawa 2007, s. 63-72; Klasyfikacja diagnostyczna DC:0-3. Opisy kliniczne dzieci oraz ich rodzin. Jak korzystać z Klasyfikacji diagnostycznej zaburzeń psychicznych i rozwojowych w okresie niemowlęctwa $i$ wczesnego dzieciństwa w procesie diagnozy i planowania terapii, Oficyna Wydawnicza „Fundament", Warszawa 2007, s. 197-267.

${ }^{18}$ M. Kupisiewicz, dz. cyt., s. 189. 
lą się na trzy podtypy: nadreaktywność, podreaktywność oraz poszukiwanie wrażeń sensorycznych. Wiele spośród nietypowych zachowań dzieci ze spektrum autyzmu można wyjaśnić procesami nieprawidłowej modulacji zmysłowej, zaś ich funkcjonowanie sensoryczne rozpatrywać w perspektywie kontinuum między hiperreaktywnością i hiporeaktywnością. Modulacja jest odpowiedzialna za reakcje organizmu na bodźce pochodzące ze środowiska, adaptowanie się do warunków panujących w otoczeniu, regulację stanu emocjonalnego oraz kierowanie uwagą.

Nadreaktywność sensoryczna, nazywana także obronnością zmysłową, związana jest z szybką, nieproporcjonalną do sytuacji, intensywną reakcją na bodziec sensoryczny. Wskaźnikiem behawioralnym nadreaktywności może być walka - zachowania zakłócające, a nawet agresywne, bądź ucieczka, na przykład zatykanie uszu w reakcji na niektóre dźwięki, uciekanie od ich źródła czy też krzyk. Nadwrażliwość może dotyczyć zmysłu jednej modalności lub też współwystępować z nadwrażliwościami w obrębie pozostałych systemów zmysłowych. U dzieci ze spektrum autyzmu możemy obserwować szeroki wachlarz różnorodnych wskaźników behawioralnych świadczących o nadwrażliwości: pocieranie, przecieranie ciała, rolowanie ubrań, uderzanie i opukiwanie się, krzyk, płacz. Barierą tkwiącą w otoczeniu, utrudniającą funkcjonowanie, jednocześnie będącą katalizatorem nietypowych zachowań może być w obrębie:

- systemu słuchowego: dźwięk szkolnego dzwonka, instrumentów, śpiewanie piosenki, echo na sali gimnastycznej czy basenie, dźwięk spłukiwanej wody w toalecie, gwar, stukanie szpilek, odgłos spożywanego pokarmu - chrupanie;

- systemu dotykowego: tekstura ubrań, drażniąca skórę aplikacja, metka, szew skarpetki, kołnierzyk, plusz wewnątrz bluzy, oddech osoby stojącej obok, dotknięcie kanapki, struktura pokarmu, malowanie farbami, klejenie;

- systemu przedsionkowego: strach lub nadmierny odruch asekuracyjny w czasie odrywania nóg od podłoża, wchodzenia i schodzenia po schodach, przejścia przez korytarz, wykonywania aktywności w ramach wychowania fizycznego;

- systemu węchowego: zapach dochodzący ze stołówki, przebieralni, perfumy, zapach lakieru do włosów, kosmetyków.

U podstaw nadwrażliwości leży obniżony próg odczuwania, który jednocześnie skutkuje wysokim poziomem lęku. Nadwrażliwość i towarzyszący jej lęk powoduje, iż dziecku z autyzmem jest jeszcze trudniej zerwać z rutyną, planem dnia. Skutecznie utrudnione jest płynne przechodzenie z jednej czynności w drugą. Stale bombardowane sensorycznymi informacjami dziecko ucieka od sensorycznie przeładowanej rzeczywistości w świat stałości, schematyzmu, powtarzalności, rytuału. Wówczas koncentracja na małym, fragmentarycznym wycinku rzeczywistości - kołyszących się liściach za oknem, unoszącym się w łunie światła paproszku lub zwykłej nitce na dywanie, otwieranie i zamykanie drzwi, gaszenie i zapalnie włącznikiem światła, wkładanie i wykładanie, przynosi ukojenie. Rąbka tego tajemniczego świata uchyla swoim czytelnikom Donna Williams: 
Po jakimś czasie nauczyłam się uciekać od świata, w co tylko chciałam. Mogły to być wzory na tapecie lub dywanie, jakiś powtarzający się dźwięk; na przykład głuchy odgłos, jaki powstawał, kiedy klepałam się po brodzie. Nawet ludzie nie stanowili już problemu. Ich słowa wydawały się bezładną paplaniną, a ich głosy jedynie szeregiem dźwięków. Mogłam na nich patrzeć aż do chwili, kiedy mnie już z nimi nie było. Później nauczyłam się zatracać nawet w ludziach ${ }^{19}$.

Na przeciwstawnym biegunie lokują się zaburzenia modulacji o podtypie podreaktywności, wówczas reakcja na bodziec zmysłowy jest powolna, potrzeba silnego, zintensyfikowanego bodźca, aby podjąć działanie, na przykład zejść z karuzeli po długotrwałym wirowaniu, zauważyć zmianę temperatury, reagować na to, co dzieje się w otoczeniu, usłyszeć wołanie, wejście i wyjście osoby z pomieszczenia, a nawet zidentyfikować ból po uderzaniu głową w zagłówek tapczanu czy w podłogę.

Kolejny, trzeci podtyp zaburzeń modulacji to poszukiwanie wrażeń sensorycznych, a więc aktywne domaganie się zaspokojenia wygórowanych potrzeb zmysłowych, co często wiąże się z przekroczeniem lub złamaniem ogólnie przyjętych norm postępowania. Dzieciom o tym podtypie zaburzeń bardzo trudno jest przejąć kontrolę nad zachowaniem, niekiedy przybiera ono skrajną, autoagresywną formę. Z uwagi na nienasyconą potrzebę sensorycznego zaspokojenia dzieci z autyzmem poszukujące silnych wrażeń zmysłowych mogą zjadać, oblizywać lub obwąchiwać osoby i obiekty w otoczeniu, wspinać się na meble, skakać, kręcić się w kółko, zbliżać źródła światła do gałki ocznej, wpatrywać się w przedmioty, machać, potrząsać nimi na wysokości oczu, pocierać powieki, wyrywać rzęsy. Williams opisuje to w następujący sposób:

Podczas zabaw i lunchu piłyśmy z Sandrą tak dużo wody, że miałyśmy wrażenie, że za chwilę pękniemy. Zaczynałyśmy się wtedy dusić. Nawet nasze twarze stawały się niebieskie, po czym, z ledwością łapiąc oddech, dostawałyśmy ataku kaszlu. Wpychałyśmy sobie do środka oczy, żeby lepiej widzieć kolory, i krzyczałyśmy aż do bólu gardła. Uważałam to za świetną zabawę. Odkryłam wtedy, że potrafię dzielić się fizycznymi doznaniami. W towarzystwie innych osób moje zmysły nie działały i stawałam się tak bardzo nieczuła, że dopiero sytuacje ekstremalne pobudzały je do reakcji ${ }^{20}$.

Kolejny podtyp zaburzeń modulacyjnych stanowią zaburzenia ruchowe o podłożu sensorycznym. Objawiają się pod postacią dyspraksji - ang. dyspraxia bądź zaburzeń posturalnych $-\mathrm{z}$ ang. postural disorder. Pod pojęciem dyspraksji kryją się zaburzenia na poziomie motorycznym, a więc wykonawstwa czynności, oraz poznawczym, czyli wizualizacji jej przebiegu. Jej rezultatem są zaburzenia w zakresie planowania oraz realizacji sekwencji czynności ruchowych zarówno w obrębie motoryki dużej, a więc pracy dużych grup mięśniowych (na przykład ubieranie się), jak i motoryki małej (na przykład wycinanie, pisanie, rysowanie, posługiwanie się sztućcami) czy artykulacyj-

${ }^{19}$ D. Williams, Nikt nigdzie. Niezwykła autobiografia autystycznej dziewczyny, Wydawnictwo Fraszka Edukacyjna, Warszawa 2011, s. 6.

${ }^{20}$ Tamże, s. 22. 
nej ${ }^{21}$. Zaburzenia posturalne natomiast odnoszą się do stabilizacji ciała oraz dystrybucji napięcia mięśniowego.

Trzecim typem zaburzeń przetwarzania sensorycznego są zaburzenia w zakresie różnicowania sensorycznego. Dyskryminacja jest ważnym elementem przetwarzania sensorycznego, obejmującym ocenę właściwości oraz różnicowanie bodźców pochodzących z otoczenia, na przykład różnicowanie głosek podobnych pod względem graficznym czy fonetycznym, różnicowanie konsystencji, temperatury, struktury pokarmów, ich smaków oraz zapachu czy też uruchamianie odpowiedniej siły w zabawie, samodzielnego huśtania się, jazdy na rowerze.

Inną klasyfikację zaburzeń przetwarzania sensorycznego zaproponowała amerykańska badaczka Winnie Dunn. Stworzyła autorski Model Czterech Kwadrantów Przetwarzania Sensorycznego (Dunn's Four Quadrant Model of Sensory Processing) oparty na zależnościach między niskim i wysokim neurologicznym progiem pobudzenia a kontinuum reakcji behawioralnej - od reakcji pasywnej do aktywnej. Te dwa komponenty badaczka przedstawiła za pomocą krzyżujących się osi, wyznaczając tym samym czteroelementowy model przetwarzania sensorycznego. Reakcje behawioralne dla niskiego progu pobudzenia mogą przybrać postać pasywną i objawiać się jako wrażliwość sensoryczna - z ang. sensory sensitivity, szybkie identyfikowanie bodźców w otoczeniu, wzmożona rozpraszalność pod wpływem bodźców. Mogą też przybrać postać aktywną i ujawniać się jako sensoryczne unikanie - $\mathrm{z}$ ang. sensory avoiding. Natomiast dla wysokiego progu pobudzenia na biegunie reakcji pasywnych charakterystyczna jest słaba rejestracja - $\mathrm{z}$ ang. low registration, czyli niedostrzeganie bodźców, bierność, odcięcie się, zaś dla reakcji aktywnych typowe jest poszukiwanie sensoryczne $-\mathrm{z}$ ang. sensory seeking ${ }^{22}$.

\section{Rekomendacje}

Zaburzenia w zakresie przetwarzania sensorycznego mogą wzmagać trudności oraz deficyty w funkcjonowaniu społecznym ${ }^{23}$ i komunikacyjnym ${ }^{24}$ dzieci ze spektrum autyzmu. W tej perspektywie zasadne okazuje się włączenie oceny funkcjonowania sensorycznego jako jednego z kluczowych elementów diagnozy funkcjonalnej dzieci z autyzmem zarówno na poziomie poradni psychologiczno-pedagogicznej, jak i późniejszej diagnozy przedszkolnej oraz szkolnej w ramach wielospecjalistycznej oceny funkcjonowania ucznia (WOPFU) i konstruowania indywidualnego programu

${ }^{21}$ M. Kupisiewicz, dz. cyt., s. 91.

22 M. Wiśniewska, dz. cyt., s. 49-52.

${ }^{23}$ C.L. Hilton et al., Sensory responsiveness as a predictor of social severity in children with high functioning autism spectrum disorders, "Journal of Autism and Developmental Disorders" 2010, Vol. 40, s. 937-945.

24 A.E. Lane, Sensory processing subtypes in autism: association with adaptive behavior, "Journal of Autism and Developmental Disorders" 2010, Vol. 40, s. 112-122. 
edukacyjno-terapeutycznego (IPET). Wśród rekomendacji do planowania i organizacji pracy z dziećmi ze spektrum autyzmu są między innymi:

- wieloprofilowa, funkcjonalna diagnoza obejmująca specyfikę odbioru i przetwarzania bodźców zmysłowych;

- wzrost świadomości specyfiki funkcjonowania sensorycznego dzieci ze spektrum autyzmu wśród nauczycieli oraz ich rodziców;

- akceptacja odmiennego, ale nie gorszego funkcjonowania sensorycznego;

- systematyczny monitoring poziomu pobudzenia dziecka oraz zaspokajanie indywidualnych potrzeb sensorycznych jako strategia proaktywna wobec dzieci ze spektrum autyzmu;

- stosowanie strategii zaradczych - tzw. alert programy (ukierunkowane na naukę stosowania przez dziecko technik samoregulacji, zwłaszcza podczas mierzenia się z sytuacją emocjonalnie trudną, niepowodzeniem - jako odpowiedź na pytanie Co moge zrobić, aby poczuć się lepiej? oraz potrzebę wyciszenia, ukojenia), plany dnia oraz aktywności, „apteczki sensoryczne” (podręczne akcesoria, na przykład w koszyczku, worku, zawieszone na smyczy, które pozwolą dziecku w społecznie akceptowany sposób zaspokoić potrzebę sensoryczną: taśmy typu thera band, grippery, fidget toy, zabawki typu squeeze, a więc takie, które dzięki swoim właściwościom są podatne na rozciąganie, zgniatanie, ugniatanie), pokoje/przestrzenie wyciszania lub zaspokajania poprzez odpowiednią stymulację zmysłową jako profilaktyka występowania zachowań zakłócających;

- tworzenie przyjaznego sensorycznie środowiska - odpowiednia infrastruktura przedszkola i szkoły;

- spojrzenie na ars educandi przez „sensoryczne okulary”;

- tworzenie warunków dla edukacji włączającej poprzez kształtowanie wrażliwości i gotowości do akceptacji inności, różnorodności wśród uczniów, rodziców i nauczycieli.

\section{Podsumowanie}

Z uwagi na niejednorodność objawów i poziomów intensyfikacji trudności sensorycznych w codziennym funkcjonowaniu specyfika odbioru i przetwarzania bodźców sensorycznych u dzieci ze spektrum autyzmu jest zagadnieniem bardzo złożonym i trudnym. Zaburzenia modulacji korespondują z wieloma kardynalnymi cechami autyzmu. Oznacza to, że zrozumienie funkcjonowania dzieci ze spektrum autyzmu, planowanie działań terapeutycznych oraz stawienie prognoz ich dalszego rozwoju nie może odbywać się bez rozstrzygnięcia, jaki jest ich aktualny profil sensoryczny. Wciąż jednak mało jest badań podnoszących kwestię specyfiki odbioru i przetwarzania bodźców sensorycznych u osób ze spektrum autyzmu.

Interesującym wyzwaniem badawczym byłoby ukazanie przetwarzania sensorycznego z ich perspektywy. Myślę, że najlepszą konkluzją będzie oddanie głosu jed- 
nej z najsłynniejszych osób ze spektrum autyzmu, Temple Grandin: „Naukowcy, którzy będą chcieli się dowiedzieć, jak to jest być jednym z wielu, wielu ludzi, którzy żyją w alternatywnej rzeczywistości sensorycznej, będą musieli ich o to sami zapytać”25.

\section{Bibliografia}

Ayres J., Integracja sensoryczna a zaburzenia uczenia się, Harmonia, Warszawa 2018. Bogdashina O., Sensory perceptual issues in autism and Asperger syndrome. Different Sensory Experiences - Different Perceptual Words, Jessica Kingsley Publishers, London 2016.

Borkowska M., Integracja sensoryczna $w$ rozwoju dziecka. Podstawy neurofizjologiczne, Harmonia, Gdańsk 2018.

Delacato C., Dziwne, niepojęte. Autystyczne dziecko, Fundacja Synapsis, Warszawa 1995.

Gałecki P., Pilecki M., Rymaszewska J., Szulc A., Sidorowicz S., Wciórka J. (red.), Kryteria diagnostyczne zaburzeń psychicznych DSM-5, Edra Urban \& Partner, Wrocław 2018.

Grandin T., Mózg autystyczny. Podróż w głąb niezwykłych umysłów, Copernicus Center Press, Kraków 2018.

Hilton C.L. et al., Sensory responsiveness as a predictor of social severity in children with high functioning autism spectrum disorders, "Journal of Autism and Developmental Disorders" 2010, Vol. 40.

International Classification of Diseases, 11th Revision, https://icd.who.int/en [dostęp: 28.10.2019].

Klasyfikacja diagnostyczna DC:0-3. Opisy kliniczne dzieci oraz ich rodzin. Jak korzystać $z$ Klasyfikacji diagnostycznej zaburzeń psychicznych i rozwojowych wokresie niemowlęctwa $i$ wczesnego dzieciństwa w procesie diagnozy i planowania terapii, Oficyna Wydawnicza „Fundament”, Warszawa 2007.

Klasyfikacja diagnostyczna DC:0-3R. Klasyfikacja diagnostyczna zaburzeń psychicznych i rozwojowych w okresie niemowlęctwa $i$ wczesnego dzieciństwa, Oficyna Wydawnicza „Fundament”, Warszawa 2007.

Kranovitz C., Nie-zgrane dziecko. Zaburzenia przetwarzania sensorycznego - diagnoza i postępowanie, Harmonia, Gdańsk 2012.

Kupisiewcz M., Integracja sensoryczna, [w:] tegoż, Słownik pedagogiki specjalnej, Wydawnictwo Naukowe PWN, Warszawa 2014.

Lane A.E. et al., Sensory processing subtypes in autism: association with adaptive behavior, "Journal of Autism and Developmental Disorders" 2010, Vol. 40.

${ }_{25}$ T. Grandin, dz. cyt., s. 107. 
Maas V., Integracja sensoryczna a neuronauka - od narodzin do starości, Fundacja Innowacja, Warszawa 2007.

Maas V., Uczenie się przez zmysty, Harmonia, Gdańsk 2016.

Miller L., Dzieci w świecie doznań. Jak pomóc dzieciom z zaburzeniami przetwarzania sensorycznego?, Harmonia, Gdańsk 2016.

Przyrowski Z., Integracja sensoryczna. Wprowadzenie do teorii, diagnozy i terapii, Empis, Warszawa 2012.

Williams D., Nikt nigdzie. Niezwykła autobiografia autystycznej dziewczyny, Wydawnictwo Fraszka Edukacyjna, Warszawa 2011.

Wiśniewska M., Profil Sensoryczny Dziecka (PSD) - model diagnozy profilu sensorycznego dzieci z zaburzeniami w rozwoju, Pracownia Testów Psychologicznych i Pedagogicznych, Gdańsk 2014.

\title{
"Understanding the inconceivable" - The reception and processing of sensory stimuli in children with autism spectrum disorder
}

\begin{abstract}
The article considers atypical sensory functioning of children with autism spectrum disorder. The redefinition of autism contained in the Classification of Psychiatric Disorders of the American Psychiatric Association DSM-5, including hyper- or hyporeactivity in the diagnostic criteria, justifies the adoption of a sensory perspective in a multi-profile diagnosis and in the planning of educational and therapeutic interventions. The article is an attempt to reconstruct Jean A. Ayres' theory of sensory integration and to show the sensory difficulties experienced by those on the autistic spectrum. The article outlines the typology of sensory processing disorders advanced by Lucy Jane Miller and Winnie Dunn. For a better understanding of the functioning of the child with autism spectrum disorder it is important to analyse his/her individual sensory profile. The specific reception of sensory expressions disturbs or sometimes prevents the child's full participation in the life of preschool or school, and handicaps learning. It is important to eliminate sensory barriers and to create a sensory friendly environment. The article emphasises that the sensory needs of children with autism spectrum disorder are an important factor conditioning their psycho-motor and social-emotional development. The article also presents practical implications.
\end{abstract}

Keywords: autism spectrum disorder, sensory processing disorder

\footnotetext{
About the author: Dorota Pufund - PhD student of pedagogy at the Kazimierz Wielki University in Bydgoszcz. Pedagogical therapist and sensory integration therapist, Polish philologist, early education educator. She works as a teacher in one of the psychological and pedagogical counselling centres in Bydgoszcz, where she is involved with the diagnosis and therapy of children, supports parents and teachers. She is interested in issues of special educational needs, diagnosis and therapy of the child, autism spectrum disorder and sensory processing disorder.
} 


\title{
Love in parenting, upbringing and education of the infants (Contribution to the history of institutional pre-school education in the 19th century using the example of Trnava town)
}

\begin{abstract}
The establishment of pre-primary educational institutions, brought recognition to pre-schools in most countries as the most appropriate place for the preparation of a child for life and school. From the beginning of institutional or private efforts to educate young children in theory and practical subjects, there were efforts to conceive pre-school educational institutions on the principles of holistic development with a deep understanding of the world of children and their psyche, as well as to prepare suitable teachers for these children. The existence of a pre-school in Trnava, demonstrates that this was in place from the start of the 19th century, and especially in activities of teacher Anthony Rehlingen.
\end{abstract}

Keywords: pre-school education, educatin, teacher, history, love

\footnotetext{
* Doc. PhDr. Zuzana Lopatková, PhD. (born in 1977 in Nová Baňa). Associate Professor at the Department of History of the The Faculty of Philosophy and Arts at Trnava University in Trnava. Her work is focused on new Slovak history, specializing in the history of the Church, history of education, regional history and personalities of modern times. She collaborates on fifteen scientific research projects and is a principal project leader of four scientific and research projects. She is a co-author of the monographs of Horné Orešany (2006), Ružindol (2008), Buková (2010), Smolenice (2011), Biely Kostol (2014) and three monographs on the history of education in Slovakia. Her most significant publications include the monograph of Martin Kollár 1853-1919 (2009), Canonical Visitation of the Smolenice Decanate in the 18th Century (2011) and The Canonical Visitation in North-Western part of Deanery Submontanus in the Second Half of the 16th Century and 17th Centu$r y$ (2014). She is the author of more than fifty scientific studies and professional articles.
} 
The birth of institutional pre-school education in Europe at the turn of the 19th century was not only related to the ideological opinions and pedagogical insights of important philanthropic individuals and societies, but also to the socio-economic situation, contingent mainly on the development of industry and trade. ${ }^{1}$ At the beginning of the 19th century, a type of childcare institution had arisen that had a social function. It kept children of a working-class background off the streets. Across many countries ${ }^{2}$, the industrial revolution had not created favourable conditions for these children. The development of an inexpensive workforce of women and children prompted the need for a new approach to day-care for children.

The most successful introduction of childcare is generally considered to be the so-called 'infant school' in New Lanark in Scotland, founded in 1816 by Robert Owen. ${ }^{3}$ In England, the first infant school in Westminster, London was established in 1820, followed by a similar establishment in the Spitalfields district, run by Samuel Wilderspin. Wilderspin wrote the first book on the education of children under the title Infant Education or Remarks on the Importance of Educating the Infant Poor (1823). This book is considered to be responsible for the spread of infant schools across Europe. ${ }^{4}$ Seismic social changes during the 19 th century altered the family structure, the status of the mother and of pre-school education. In developed European countries, the reform school and education movement were born. Population movement from villages to cities changed the demographic structure of towns. The living conditions of working-class children prompted the need for social care of young children.

In the first half of the 19th century, revolutionary ideas emerged from Western Europe regarding women's position in society. In the thirties, there were pre-school facilities in several countries, not only in England and France. From early in the 19th century pre-school institutions were established in industrialised countries. The emergence of pre-school caregivers did not only concern Europe; similar trends were seen in the United States - in New York in 1835, there were already 27 such institutions. Even in South Africa, the success of 'infant schools' was celebrated thanks to James Buchanan. These early pre-school facilities formed the basis for the development of pre-school institutions into the future. But let us return to Europe. In the 1930s, infant

${ }^{1}$ In most states, with the Industrial Revolution, workers had a disproportionately long working day, and were under threat of permanent redundancy, which was why parents left young children unsupervised for many hours. Left to fend for themselves many suffered from hunger, malnutrition and various diseases. M. Bartušková, Společenská předškolní výchova v době vzniku našich prvních opatroven, [in:] Kapitoly z histórie materského školstva na Slovensku, Bratislava 1970, pp. 49-50.

2 Ministry of Interior of the Slovak Republic, State Archives in Bratislava, Trnava Branch, Trnava Child Care Centre 1832-1863, carton no. 3, inventory no. 124, Die Kinderbewahranstalten, August 1844, pp. 2-3.

${ }^{3}$ O. Siméon, Robert Owen's Experiment at New Lanark: From Paternalism to Socialism (Palgrave Studies in Utopianism), Utopian Studies, 2017, pp. 13-44.

${ }^{4}$ B. Kasáčová, Od detských opatrovní po predškolskú edukáciu, [in:] E. Gašparová, M. Miňová. (eds.), Od detskej opatrovne k materskej škole, Banská Bystrica 2009, p. 5 onwards. 
schools were established in the Netherlands, Sweden, and Hungary, where collections and charity events were organised to improve conditions for the poor and, in particular, care for pre-school children. Various charities funded caregivers and shelters aiming to protect three to six-year-olds from the dangers of wandering the streets and related delinquency. Infant schools taught children proper personal hygiene, provided them with a basic education, and catered to their moral development. In addition to day care, an educational training program was implemented in these facilities. ${ }^{5}$

Philanthropy and volunteerism in the Habsburg monarchy, inspired by Christian values, contributed greatly to addressing the social situation of poor working-class families, by supporting the founding of charitable associations. One of those engaged in these activities was Therese Countess von Brunswick, who, at the turn of the 19th century, dealt with pedagogical issues in the Kingdom of Hungary. Her inspiration came from the works of Johann Heinrich Pestalozzi ${ }^{6}$ and Friedrich Fröbel ${ }^{7}$, which introduced the theory of pre-school education in Europe and emphasised the development of the natural abilities of groups of children while taking into account the specific character of each individual. ${ }^{8}$ Therese Countess von Brunswick, ${ }^{9}$ together with her secretary, Anthony Rehlingen, published promotional leaflets and founded philanthropic societies whose aim was to financially and pedagogically support

${ }^{5}$ J. Levická, Detské opatrovne, [in:] V. Hornáčková, D. Kollárová (eds.), Detská opatrovňa v Trnave a jej aktuálnost'dnes, predškolská výchova ako výchova k harmónii, Faculty of Education, Trnava University, Trnava 2002, pp. 23-24.

${ }^{6}$ Johann Heinrich Pestalozzi (1746-1827) saw the misery of the people during his deprived upbringing. He saw education as a means of improving one's social situation. Influenced by the ideas of Jean-Jacques Rousseau, he first created a system of elementary pedagogy. According to him, teaching is meaningful when it is based on the natural development of the skills and abilities of the child. Pestalozzi proceeded in his teaching from sensory cognition to the formation of concepts. Convinced that children should study subjects in their natural environment, Pestalozzi developed a so-called „subject lesson," which included exercises to explain forms, numbers and speech. J. Levická, Detské opatrovne, p. 23.

7 In Fröbel's pedagogy, great attention is paid to the creativity of the child, which should be systematically developed through work, exercises and games. The game has a great educational significance in the child's life. Fröbel developed the childrens' games system and emphasized their place in pre-school education. J. Levická, Detské opatrovne, pp. 23-24.

${ }^{8}$ Therese Countess von Brunswick met important Swiss educator and educational reformer Pestalozzi in person, in Yverdon-les-Bains (the Swiss city where Pestalozzi opened an educational institution for children of wealthy families). She knew his pedagogical works and the works of his followers, particularly Friedrich Diesterweg and Karl John. In her memoires, Therese Countess von Brunswick recalls her travels abroad, where she worked on the establishment of pre-schools with the aristocracy and the high clergy - in Munich and Augsburg. J. Mikleš, Filantropizmus Márie Terézie Brunšvickej a zprávy slovenských časopisov o potrebe zakladat detské opatrovne v 19. storočí na Slovensku, [in:] Sborník pedagogického inštitútu v Banskej Bystrici II, SPN, Bratislava 1970, pp. 96-116.

${ }^{9}$ R. Ristovska, Brunšvikovci a ich život v Dolnej Krupej (Sonda do problematiky), Wydawnictwo i Drukarnia Towarzystwo Słowaków w Polsce, Kraków 2012, pp. 49-72. 
and lead pre-school institutions. ${ }^{10}$ After three years of trying to establish a childcare house she succeeded in 1828. The first childcare institution she established in the Kingdom of Hungary was the so-called Angel Garden, opened on 1 June 1828 in the Christina Town district of the city of Buda. Thanks to Therese Countess von Brunswick, other infant schools were established not only in Buda, Pest, but also in today's Slovakia: Banská Bystrica (1829), Bratislava (1830) and Trnava (1832). ${ }^{11}$ A governor ${ }^{12}$ entrusted the care of infant schools in Trnava to the Society for the Promotion of Good (Gesellschaft zur Beförderung des Guten) ${ }^{13}$, led by the Therese Countess Apponyi. After receiving a letter from the Trnava Municipal Administration, the founder of the pre-school, Therese Countess von Brunswick took the first steps to establish this institution. She sent her secretary and co-worker Anthony Rehlingen to Trnava, to start this process.

In the monarchy, it was customary that the opening of pre-schools was always on the name day of one of the important representatives of the Habsburg family, in the case of Trnava, it was on Monday, 5 November 1832, on the name day of the Emperor Karolina Augusta. The main role of this pre-school facility, according to Anthony Rehlingen, was to develop the physical, moral and mental abilities of children. Childcare was financially dependent on the charity of individual donors ${ }^{14}$ and members of the Society for the Promotion of Good. The main source of income, however, was the endowment, which was the long-term financial property of a pre-school, and was never used for the operation of the institute. An example of such an endowment was a donation of 3000 Guldens by Count Apponyi and 5000 Guldens by the city.

The aim of setting up a pre-school in Trnava was to foster the religious and moral education of children of pre-school age. These newly established institutes took in both boys and girls, especially of poor parents, aged between two - three and seven years, with an aim to educate children in a pleasant and varied way. The ethos of these institutions, described by Anthony Rehlingen, was that children should be given the opportunity to play in a safe and caring environment, with consideration given to their moral development, thus providing them with the best prospects for the future.

10 Ministry of Interior, State Archives in Bratislava, Trnava Branch, Trnava Children's Care Centre 1832-1863 [further as: TCCC], carton no. 1, inv. no. 122, A. Rehlingen: Gedichte, 1833, p. 31, no. 19. "Städtische Pressburger Zeitung", 10 August 1832, Carl Angermayer, Pressburg (Bratislava), 1764-1929.

11 The statement on the status of childcare in the royal free cities of Buda and Pest, published in the Städtische Pressburger Zeitung in 1832, states that between July 1831 and July 1832, 656 children were admitted to six institutions.

12 J. Mikles, Filantropizmus Márie Terézie Brunšvickej a zprávy slovenských časopisov, p. 25.

13 The Trnava magistrate approved the proposal with the remark that the costs will not be paid by the city, but that the announcement will be made public and those who can afford to should voluntarily contribute. J. Šimončič, Detská opatrovňa v Trnave v rokoch 1832-1863, [in:] Mojej Trnave. K dejinám Trnavy a okolia. Trnava 1998, pp. 287-290.

14 TCCC, op.cit., carton no. 1, inv. no. 1, Tagebuch über die Tyrnauer Bewahrschule (next Tagebuch), November 1-11, 1832. 
These were lofty goals, but they were achieved. Visitors ${ }^{15}$ to the infant schools were amazed by the loving treatment of the children. For example, Transylvania's Professor Ladislav László wrote that he very much preferred the infant school in Trnava to the one in Cluj-Napoca in Romania, which was more focused on rigorous education. In Trnava, the environment was more caring, more entertaining and, therefore, more appropriate to the age-group. He particularly liked the dancing and singing classes. ${ }^{16}$ If needed, teaching assistants were assigned a teacher, who was responsible not only for the children's education but also for their everyday needs, hygiene etc. The children were not to be left unsupervised while in the school. ${ }^{17}$

Great attention was devoted to the students' progress. The teachers wrote up notes each month and the results of individual pupils were compared. We learn about everyday life in the pre-school in Trnava from these teachers' logs: the first was Anthony Rehlingen, replaced by John Koholzer, followed by Max Planger, Joseph Gamperling and finally Anthony Rácz. ${ }^{18}$ These preserved logbooks also include the writings of the secretary, of Rieder's and of Count Apponyi, who substituted for the teaching staff in their absence. The main goal of these teachers was to achieve the key aim of education to develop each child's potential in a holistic way. ${ }^{19}$

In this study, we are looking in detail at the work of Anthony Rehlingen, who was the first, and probably the most successful, teacher in the Trnava child care centre. From his diaries, teaching preparation and thoughts we can sense a natural-born teacher. ${ }^{20}$ Anthony Rehlingen applied his pedagogical ideals right from the start of the pre-school. He devoted himself to a small group of children in the still unfinished classroom. He let the children play to get to know each other and get used to the teacher as well as the school premises. When he saw that they were getting bored, he taught them about school rules and teaching aids, such as slate tables, abacuses, wall paintings, and so on.

He also explained some basic rules of hygiene, followed by marching. Throughout this he was observing them and studying their character. There were troubled children in the group. In his diary A. Rehlingen mentions one such boy, Louis Gétzy, who

15 The most eminent visitor in Trnava was the Emperor Francis Joseph I. (13th August, 1852), who received a deputation from the Children's Care Centre. TCCC, op.cit., carton no. 2, inv. no. 87, Tagebuch, August 13, 1852.

${ }^{16}$ TCCC, op.cit., carton no. 1, inv. no. 1, Tagebuch, October 3, 1833. [Comp.:] F. Pill, Trnavská detská opatrovña v rokoch 1832-1863, (Coursework), Trnava 1961, p. 56. The manuscript is saved in Ministry of Interior, State Archives in Bratislava.

${ }_{17}$ J. Šimončič, Detská opatrovňa v Trnave v rokoch 1832-1863, p. 287.

${ }_{18}$ J. Šimončič, Vývoj a archívna charakteristika fondu detskej opatrovne v Trnave, [in:] V. Michalička et al., Dejiny predškolskej výchovy na Slovensku, Zborník Múzea školstva a pedagogiky, Bratislava 1999, p. 38-39.

${ }_{19}$ M. Krajčovičová, Rozvoj tvorivosti v súčasnej materskej škole, https://www.researchgate.net/ publication/303899177 Rozvoj tvorivosti v sucasnej materskej skole Development of creativity in contemporary pre-school [access: 30.06 .2018 ].

${ }^{20}$ J. Šimončič, Detská opatrovňa v Trnave v rokoch 1832-1863, p. 288. 
was from a deprived home, similar to most of the children in the school. The teacher described the boy's character: "This boy is a pretty cruel master of his surroundings. Insolence, ferocity, obstinacy and greediness are features of his character, which he can hide as much as the cat can hide its claws. He treats the others badly, beats them, quarrels with them, pushes them, etc. An 'attack' on his things resulted in pitiful cries and terrible grimaces. When I reproached him for his evil behaviour and threatened him with a rod, only to see if he could be moved by that remedy, he replied that nothing would happen. The boy is only two years old. Well, I believe that in a few days I will see visible signs of improvement." On November 10, 1832, the teacher again mentioned Louis Gétzy, but with the remark that he was very good, he only needed attention and "a cultivation of heart." With his kind approach, Rehlingen was able to get the attention and respect of the children very quickly, as evidenced by his writings in the November 11, 1832 diary: "[...] we have seen and demonstrated how order and symmetry can evolve from disorder; obedience from disobedience; consistency from inconsistency. At first it was chaos, everything was flying around, there were battles, banging, crying, spitting, buzzing and drumming, all that was heard was stronger tones and movements, like thunder and lightning in a storm. Now there is a cheerfulness, showing a nice image of a pre-school in which children learn the virtues of obedience, which is key. I cannot adequately express my appreciation for Catherine Ek, especially her passion, her adaptability, her love for children and her tact." Rehlingen taught through games and attributed great importance to the joyful and caring environment at the school. Visitors were amazed at his kind treatment of the children, without any harsh discipline that was common in similar institutes at that time.

Rehlingen considered the pre-schools primarily educational and not social institutions. He was of the opinion that "if we leave the earth alone, it will only grow weeds. Cultivated land grows sweet fruits, and so it is with human nature [...]"21 Rehlingen was particularly keen on exploring nature, different animal species and plants. In his pedagogical practice he used every opportunity to go out with the children to the countryside, and in the school garden he used domestic plants to explain development and growth. Among these plants were wheat, rye, barley, corn, lentils, peas, beans, millet, flax and poppy. "Fun in the countryside," Rehlingen wrote, "is really refreshing for kids. They walk, march, run, jump, and hop. Small races strengthen their lungs. Jumping over sticks brings them a lot of joy." 22

A. Rehlingen was convinced that a pre-school teacher should direct children's fun in a kind and gentle way. He considered games to have educational significance, develop children's acumen and benefit their health. He also believed that they played a role in deepening moral and esthetical principles. ${ }^{23} \mathrm{He}$ introduced cubes to the play-

${ }_{21}^{21}$ TCCC, op.cit., carton no. 1, inv. no. 6, Tagebuch, 16-26 January 1833.

22 TCCC, op.cit., carton no. 1, inv. no. 9, Tagebuch, 18 March - 13 Apri1 1833.

${ }^{23}$ TCCC, op.cit., carton no. 1, inv. no. 3, Tagebuch, July 18, 1832. Compare F. Pill, Trnavská detská opatrovňa v rokoch 1832-1863, p. 60. 
room, which were supplied by a carpenter. He describes the benefits of these toys: „For children, the kits are an excellent toy because they cannot break them and they are very colourful. They allow the children to make connections, encourage thinking and improve insight. They are enjoyable for children and adults alike." ${ }^{24}$ Further diary entries show more evidence of his kind approach to education: "Consider the natural inclinations of the child; it is not good to force a child to sit still when he wants to walk, to force him to walk when he wants to stand. Activity is a natural need of the body, and strengthens it. Children need to enjoy freedom - as long as they satisfy a healthy need. Moodiness, however is not to be tolerated." ${ }^{25}$

Anthony Rehlingen had ideals regarding education. He considered the best upbringing to be one with as little coercion and violence as possible. Instead, it was necessary to plan learning opportunities where children perform their duties as if by their own will. The children's attention was improved by removing all disturbing influences, strong mental stimulation, resulting in emotions such as fear, horror or joy. He tried to encourage their natural curiosity and inspire a cheerful mood. ${ }^{26}$ For these reasons, Rehlingen attributed great importance to learning songs. He talked about beauty and singing as harmony: "Beauty is the harmony of expression in tangible form; truth is the inner harmony of thoughts, emanating from reason, virtue or moral good, in the same way as the harmony of ideas expressed in action. Nothing is easier to wake in a child than the feeling of beauty, which is, as Friedrich Schiller very rightly notes, the meaning of the spirit. The feeling of beauty is firstly awakened by music. If music is taught to a child effortlessly and, most importantly, without coercion, love for music leads to a love for life, especially with regard to spiritual and moral education. Then music has a beneficial influence on all learning and on practical life. Music becomes the essence of everything we learn and what we do and becomes the heavenly spirit that accompanies us everywhere and transforms the greatest disharmony into harmony. This spirit elevates our senses and moves us from low to gentle, from human to divine." 27

In connection with this quote from Rehlingen's record, specific situations that arose in the care centres, alluded to in Rehlingen's notes, demonstrate the introduction of moral principles. When a difficult situation was resolved, the teacher pointed out that the children had learned a moral lesson. In the case of a mother who has succumbed to the will of her son only to satisfy his desire, M. Slavik gave an example of Temistokles's son, who once said, "My will is the will of Athenians, for what I want, my mother wants and what she wants, even my father wants and his will is the will

${ }^{24}$ TCCC, op.cit., carton no. 1, inv. no. 6, Tagebuch, 16-26 January 1833.

25 TCCC, op.cit., carton no. 1, inv. no. 8, Tagebuch, 20 February - 16 March 1833.

${ }^{26}$ J. Mikleš, Rehlingenovo pedagogické pôsobenie v detskej opatrovni v Trnave, [in:] Sborník pedagogickej fakulty v Banskej Bystrici VIII. Pedagogika-Psychológia, Bratislava 1966, p. 67.

${ }_{27}$ TCCC, op.cit., carton no. 1, inv. no. 6, Tagebuch, 16-26 January 1833. 
of the Athenians." ${ }^{28}$ He believed that the formation of will in childhood was part of the building of moral character. Adhering to a daily routine served to discipline the children's will. In this way, he cultivated a habit of regular work, which began and ended at a fixed time. In addition to the development of the child's psyche, Rehlingen emphasised the body's development and the children's health. In a playful way, using proverbs, they taught the children basic rules for health, for example: "Think about it, before you put something in your mouth, if it's a lot, it's unhealthy"; "Never doubt that ripe fruit is very healthy." ${ }^{29}$

Rehlingen opposed rote learning as a way of teaching prayers: "When they want a child to pray, they tell him a prayer formula that the child does not understand and struggles with for years. Instead of his spirit being lifted up to God, learning to know and love him, the child turns away from him." ${ }^{30}$ He condemned parents who punished their child for not being able to recite the evening prayer that neither the child (nor most of the parents) understood, sending the child to sleep upset. It is not by chance that several days after these notes were taken, a number of clergymen appeared in the nursing home to make sure that children were taught to pray. The teacher, however, assured the Church in Trnava that the children did pray and explained to them that the religion lesson was adapted to the understanding of young children. ${ }^{31}$

Anton Rehlingen's ethos, his rich theoretical knowledge and experience gained from teaching, inspired others to use his methods in the pre-schools even after his departure from the institute ${ }^{32}$ and subsequent death a few months later. It can be said that his pedagogical views permanently influenced the course of the school. Rehlingen's successors used his methods in their lesson preparation and were guided by his book on childcare facilities - Die Bewahrschule für kleine Kinder von 2 bis 7 Jahre (Kindergarten for small children from 2 to 7 years). One of the other teachers in the pre-school was Max Planger, who took up this position on 23 September 1833. In his own words, he came to the institution, "where children were protected from physical and moral hardship from an early age, had their talents developed and were brought up to be useful members of society." ${ }^{33}$ Max Planger was kind to the children, and emphasised clarity and diversity in learning. Under his supervision the children built circles, squares, blunt and sharp angles, houses, towers and bridges on the floor or on the benches. During natural history lessons they distinguished between traits of plants and animals. The children had the opportunity to use their intellect comparing

\footnotetext{
${ }^{28}$ TCCC, op.cit., carton no. 1, inv. no. 8, Tagebuch, 20 February - 16 March 1833.

${ }_{29}$ TCCC, op.cit., carton no. 3, inv. no. 123, Die Lesen-unterricht für Bewahrschulen, von Anton von Rehlingen, wailand. Lehrer der Tyrnauer bewahrschule.

${ }^{30}$ TCCC, op.cit., carton no. 1, inv. no. 7, Tagebuch, 28 January - 16 February 1833.

${ }^{31}$ TCCC, op.cit., carton no. 1, inv. no. 7, Tagebuch, 28 January - 16 February 1833.

${ }^{32}$ Rehlingen's final inscription in his diary is dated 1 May 1833. He did not forget about his schoolchildren, and he visited the children's care centre. He died on 29 March 1834 as a consequence of tuberculosis. TCCC, op.cit., carton no. 3, inv. no. 122.

${ }^{33}$ TCCC, op.cit., carton no. 1, inv. no. 11, Tagebuch, 23 September - 6 October 1833.
} 
and contrasting each example. The essence of this lesson was the cultivation of both physical and mental fitness in the children and allowing them to develop a love for work. This style of education was designed to give the children a sense of satisfaction and humility. ${ }^{34}$ In 1840, the nursing centre found itself in crisis and with no teacher. The importance of the teacher, particularly his interaction with the children became clear. The Therese Countess Apponyi took over all the pedagogical duties, but she did not know how to gain the respect of the children. The class was disruptive, the children were disobedient and noisy, their behaviour intolerable. They completely ignored the orders of the Countess. ${ }^{35}$

The arrival of a new teacher, Anthony Rácz, brought peace and order back to the centre. ${ }^{36}$ He commanded respect from the children. He continued with the method he had adopted during his time at the Toln pre-school ${ }^{37}$, whilst respecting the existing daily schedule in the centre. He was very good at German, Hungarian and, unlike his predecessors, the Slovak language. The wife of Anthony Rácz, Anna, replaced Terezia Walz as teacher in 1847. After the death of Therese Countess Apponyi in 1849, the support of the Society for the Promotion of Good was lessened, but the character of the institute remained unchanged, no crisis arose, and the teacher remained in place. The pre-school provided full-day childcare for children from $8 \mathrm{am}$ to $12 \mathrm{pm}$ and from $2 \mathrm{pm}$ to $6 \mathrm{pm}$. Between 2 and $4 \mathrm{pm}$, children could stay in the centre or go home, and this second option was used by younger children for their afternoon nap. On Saturdays, classes only ran until 12 o'clock, as every Saturday afternoon the classroom and lavatory were cleaned.

The institute was open to Trnava children of all social strata, but most of them came from deprived families, including children of invalids, widows, tailors and merchants. Orphans were also admitted. ${ }^{38}$ Children under two years and over six years were not admitted to the institute. Later, in the 1940s and 1950s, children of any age could enrol, but were admitted after reaching the age of three. Children of very poor parents were admitted free of charge, children of affluent parents were charged a monthly fee of 30 Kreutzer. Orphans were paid for by the city. ${ }^{39}$

Most of the children were Slovakian, and Roman Catholic, but Jewish and Protestant children also attended the centre. ${ }^{40}$ The children's health was regularly checked by

${ }^{34}$ J. Mikles, Filantropizmus Márie Terézie Brunšvickej a zprávy slovenských časopisov o potrebe zakladat' detské opatrovne v 19. storočí na Slovensku, [in:] Sborník pedagogického inštitútu v Banskej Bystrici II, Bratislava 1964, p. 105.

${ }_{35}$ TCCC, op.cit., carton no. 2, inv. no. 84, Tagebuch, 16 July 1840.

${ }_{36} \mathrm{~J}$. Šimončič, Vývoj a archívna charakteristika fondu detskej opatrovne v Trnave, p. 39.

37 Tolna - town in Hungary, in Tolna County.

38 TCCC, op.cit., carton no. 2, inv. no. 86, Tagebuch, 10 July 1845.

39 TCCC, op.cit., carton no. 3, inv. no. 106, Verzeichnis der Kinder welche in die Bewahranstalt aufgenommen wurden.

${ }^{40}$ TCCC, op.cit., carton no. 3, inv. no. 105, Verzeichnis der Kinder welche in die Bewahr-Anstalt aufgenommen wurden vom 11. Oktober 1841 bis 10. November 1846. 
doctors. Anthony Rehlingen commented on the social situation of some of his pupils in his diary: "Josephine and Mary Dresler are a neglected pair as are both Wohllebens. Josephine Moskall must receive very ill-treatment. Her overall behaviour has shown that she was convinced that man is a devil. But thanks to kindness, she has improved. She just has to understand that the world is not hell." ${ }^{41}$ In addition to the chairwoman of the centre who was responsible for its smooth running, the booking-clerk and the secretary, the teachers had the most important role and were required to not only look after the children but also help to educate them both spiritually and physically. The teachers supervised younger children aged three to four years old and also educated girls in handicrafts, especially in sewing. Many girls had already mastered this subject by the age of five. ${ }^{42}$ The first teacher in the centre was Catherine Ek, her successor was Terezia Walz. In $1847^{43}$ Walz was replaced by Anne Rácz, wife of Anthony Rácz. She was officially appointed to this position on 30 August 1848 by the Society for the Promotion of Good, and according to records she still worked there in 1862.

It was very important to maintain discipline and routine in the centre. The parents had to have their child at the school before eight o'clock, and in the afternoon, before two oclock. They had to ensure that their clothes were not dirty and torn. Although German was taught and spoken in the pre-school, Slovak-speaking pupils were in the majority. Anthony Rácz wrote in his diary regarding the languages spoken by the children: in July 1847, of the boys, 6 spoke Hungarian, 34 German and 42 Slovak, of the girls, 5 spoke Hungarian, 32 German and 43 of them could speak only the Slovak language. ${ }^{44}$ Teaching officially started at eight o'clock. Most children, however, usually gathered at 9 o'clock; until they all arrived, the boys counted on the counter, the girls knitted. The entire teaching process was split into 15-minute intervals to bring variety into the classroom and prevent the children from getting tired quickly. At 9.30 am the children marched in pairs into the classroom, prayers were followed by singing, the children were counted and given the order of the day. Religion teaching followed, bible stories, or Hungarian words were taught. After a break at 10.30 there was breakfast, the children had to bring their own food with them. From 11.15 to 12.00 - drawing, learning the alphabet, reading and singing, or counting, hygiene and use of aids were discussed.

From 12.00 to 13.30 there was a break. Some children used this time to leave for home, some stayed in school all the time. In the afternoon, from 13.30 to 15.00 , the children gathered in the classroom, after praying and singing, they studied biology, or counting on the counter, the girls knitted, and the boys took part in gymnastic exercises. From 15.00 to 16.00 , natural history was taught - the teacher talked about the

${ }^{41}$ TCCC, op.cit., carton no. 3, inv. no. 106, Verzeichnis der Kinder welche in die Bewahr-Anstalt aufgenommen wurden 1846-1856.

${ }^{42}$ TCCC, op.cit., carton no. 1, inv. no. 9, Tagebuch, 12 March 1833.

${ }^{43}$ TCCC, op.cit., carton no. 2, inv. no. 87, 16 February 1848.

${ }^{44}$ TCCC, op.cit., carton no. 2, inv. no. 86, Tagebuch, 22 July 1847. 
various animals, and the countryside, followed by Hungarian vocabulary and singing, reading and counting. From 16.00 to 17.00 , children played and had tea time. From 17.00 to 18.00 , children were taught crafts, spelling and reading, or gymnastics. After praying and singing, the children went home. On Saturday morning, lessons from the week were practised and repeated.

The teaching of individual subjects in school took place as follows: In religious lessons, the teacher explained to the children the meaning of the Ten Commandments, and the content of prayers, in part using examples and pictures from bible stories of the Old and New Testaments. Then writing and drawing were taught. The teacher showed the children how to make straight, curved, semi-curved, semi-circular or circular strokes, which could be used to make particular symbols. During the counting lesson, beginners counted on their fingers to ten, then to 20 , and finally on the counter with coloured balls from 50 to 100 . The advanced ones then began to add and subtract.

The children were mainly taught to name parts of the human body in Hungarian and German, then longer and shorter sentences in Hungarian which were also taught in German. Gradually, the children were taught vocabulary for all the school subjects, vocabulary relating to home, the city, etc. During natural history lessons, children first observed parts of plants and animals, and then their benefits were explained to them. They learned animal names and imitated their sounds. For example, the teacher cut off leaves from trees (apple tree, poplar), showed the differences between them, and then taught the children to name the tree. ${ }^{45}$ Singing lessons were a useful and enjoyable teaching method, teaching good listening skills and facilitating and enhancing memory. Music gave them an appreciation of aesthetics, harmony, and beauty, from which a respect for order and hygiene also arose. The children learnt moral lessons with an emphasis on moral behaviour. The teacher used events that children had experienced. For example, when one girl, Caroline Krajčovič, lost her only cross in the playground, the boy Joseph Riesh found it and didn't keep it. He instead gave it to the teacher and the teacher handed it back to the owner. The teacher reminded children of the moral lesson: "Do not deceive or steal and what you find, do not keep." ${ }^{46}$

In teaching about crafts, the teacher showed the children various tools or illustrations and explained their use. Nice, colourful, instructive pictures from the Pfennig magazine ${ }^{47}$ brought by Therese Countess Apponyi were used. The teacher asked the children questions about the craftsmen in the pictures, how they used the materials and what could be produced from the material shown.

${ }_{45}$ TCCC, op.cit., carton no. 1, inv. no. 38, Tagebuch, 4-11 May 1834.

46 TCCC, op.cit., carton no. 2, inv. no. 86, Tagebuch, 22 May 1844.

47 "Das Pfennig-Magazin der Gesellschaft zur Verbreitung gemeinnüßiger Kentnisse" was a journal published by F.A. Brockhaus between 1833 and 1842 . He dealt with issues related to classical and modern culture, politics, and later, inventions of the industrial revolution. 
The children also had a subject named technology to explain the processing of individual crops for the need and benefit of humans. Spelling was done with fun speech-based exercises, articulating the sounds and allowing the children to make the shapes with their bodies. For example, as instructed by Rehlingen, the sound M had to be articulated through the nose with a closed mouth and described its shape as: "M" consists of three identical sticks that are on top of each other", they also learned to introduce the letter "m” with their body. Three boys and three girls stood next to each other and held each other's shoulders; if weather was nice, children drew the shapes in the sand. ${ }^{48}$

The children went outdoors every day to the garden or the yard, unless the weather was too bad, for example rain, strong wind or frost. In these situations, the children stayed in the classroom. Their daily schedule also included educational activities, such as learning about nature and natural phenomena. Diversity of activities was encouraged to prevent boredom. The boys were very happy to play soldiers, marching or drumming, some walking on the hills in a predetermined place, others hopping, learning to tie knots, balancing on tree-stumps, some of the children played ball or musical games. Therese Countess Apponyi sometimes prepared a pleasant afternoon for the children in the garden when she invited a violinist. The children could sing songs and dance. ${ }^{49}$

The school year was divided into a winter and summer term. Each of them ended with an exam. The summer term finished in August and the winter term before the Easter holidays. The tests were in the form of questions and answers, and children enjoyed showing what they had learned. Christmas Eve was an important holiday in the year, which filled the children with joy and excitement. As early as November, Christmas songs began to be taught, and they were constantly asking when they could see a Christmas tree. Christmas Eve was a day off to allow for the next day's preparations, especially the distribution and packing of Christmas gifts for children. The packs consisted of pieces of clothing that were donated by members of the Society for the Promotion of Good and multiple contributors and subsequently distributed and packaged according to the names of the children. Under the Christmas tree, children received gifts such as coats, stockings, shoes, scarves, caps, toys, socks, or skirts. ${ }^{50}$ There was a presentation of Christmas poems and songs by children during the festive evening which was enjoyed by all.

The teachers tried to avoid the use of physical punishment. However, it was acknowledged that wickedness should be punished. At times, there were outbursts of anger and stubbornness when, for example, a child smashed toys. These problems most frequently arose with newcomers who needed time to adapt to being around other children and to a daily routine in the school. Some children also committed

\footnotetext{
${ }^{4}$ TCCC, op.cit., carton no. 3, inv. no. 109, Die Lesenunterricht für die Bewahrschulen.

49 TCCC, op.cit., carton no. 2, inv. no. 84, Tagebuch, 16-18 August 1836.

50 TCCC, op.cit., carton no. 3, inv. no. 126, Accounts, 1835-1863.
} 
minor thefts, or were complaining, screaming and fighting. For more serious or more frequent transgressions, strict interventions would be necessary on the teachers' part. Physical punishments or violence were prohibited in the pre-school as they were considered incompatible with the principles of education and training for young children. Teachers in the pre-school, unlike their other colleagues in such facilities, always emphasised education on the basis of leading by example and speaking kindly to the students in a way in which lessons could be learned. However, the children had to be punished for bad and inappropriate behaviour.

The usual punishment was exclusion from playing outside, or being made to stand in a circle, which was drawn with chalk. During Anthony Rehlingen's time, children were usually made to stand behind the furnace which was considered a place of shame. In particular, some boys who had experienced brutal punishment from their parents had become accustomed to being aggressive and rebellious, so teachers were occasionally required to reprimand them..$^{51}$ For example, a boy, Joseph Kalina, arrived at the institute in the afternoon at about 5 oclock, though his parents had sent him to the school at 2 oclock. It transpired that he had wandered the streets during this time. The teacher reprimanded him, and he had to promise before everybody that he would never violate the school rules again, and as punishment he was not allowed to participate in games in the garden. ${ }^{52}$

In more serious cases, of fighting or lying, the teacher made the guilty party stand in front of all the children, the deed was discussed in the class and a punishment was decided on. In the case of the two girls who stole cherries from a shop in the city and ran away, the teacher intervened, and the cherries were returned to the shop. Only one of them came to school in the afternoon, and as a punishment she was not allowed to sit on a chair or participate in games for the whole afternoon..$^{53}$ A week later, the teacher caught her younger sister red-handed and her hands were tied as punishment.

If the group was noisy their punishment was to stand at the centre of the class. However, with a large number of children, it was not a great success, as there was not enough space for this, so they had to return to their places one by one. Before deciding on any physical punishment, Therese Countess Apponyi was informed about the act that preceded the punishment, or, in her absence, the vice-chairman of the Association. ${ }^{54}$ The most serious punishment was exclusion from the school. The first time this punishment was used was in June 1834, due to the extremely bad behaviour of a pupil. In order for this punishment to act as a deterrent for all children, all her mistakes and wrong-doings were discussed on front of everybody. The teacher took the

${ }^{51}$ TCCC, op.cit., carton no. 3, Tagebuch, 21 July 1835.

52 TCCC, op.cit., carton no. 2, inv. no. 84, Tagebuch, 6 April 1843.

${ }^{53}$ School suspension gradually became a more long-term, convenient way to exclude maladjusted children from school: F. Pill, Trnavská detská opatrovňa v rokoch 1832-1863, p. 134; J. Šimončič, Detská opatrovňa $v$ Trnave v rokoch 1832-1863, pp. 287-290.

54 TCCC, op.cit., carton no. 3, Tagebuch, 14 August 1843. 
pupil's hand and accompanied her out of the pre-school while other children watched and cried. A much better approach seemed to be prevention through good example and kind words. In this spirit, the teacher Anthony Rácz introduced honest badges to the diligent and obedient pupils as encouragement. ${ }^{55}$

On turning seven, the children went to the city's normal school. The girls went to the girls' school in the Ursuline monastery. The children of the pre-schools were among the best pupils in the classroom. Over time, the systematic training of teachers for pre-school institutions created an educational basis for the development of pedagogical thinking on a wider scale. Pre-school education has ceased to be just the concern of enthusiasts and pioneers but has become part of modern pedagogy. With the establishment of pre-primary educational institutions, pre-primary education has been recognised in most countries as the most appropriate method of preparation of a child for life and school.

If today we understand pre-school education as pre-primary education, we consider it to be the product of the current epoch. However, it is also necessary to consider its history. This shows us that since the beginning of institutional and private efforts to educate small children, both theoretical and practical efforts have been made to work on the principles of holistic development with a deep understanding of a child's world and psyche. An effort has also been made to train teachers effectively for teaching these children. That this had been in place since the 19th century is evidenced by the existence of the children's pre-school in Trnava. Its teachers were not working in isolation in Trnava, on the contrary - they were informed on the latest trends in European pedagogy and had direct contact with the Paris pre-schools thanks to Therese Countess Apponyi. Numerous preserved sources, including journals on the origins and history of the institute, reports on preparation for lessons, and various other writings and accounts, show the European level of pre-school education in Trnava. ${ }^{56}$

\section{Sources}

Ministerstvo vnútra Slovenskej republiky, Štátny archív v Bratislave, pobočka Trnava, fond Trnavská detská opatrovňa 1832-1863, lad. No. 1-5.

“Das Pfennig-Magazin der Gesellschaft zur Verbreitung gemeinnüßiger Kentniss", 1833-1842.

${ }_{55}$ TCCC, op.cit., carton no. 1, Tagebuch, 14 August 1843.

${ }^{56}$ The study was developed on the basis of VEGA grant no. 1/0645/17 - Manor. A territorial state business organisation (Panstvo. Podnik zemepanského hospodárenia) and Grant APVV-160619 The Roman Curia and the Kingdom of Hungary in a communication interaction in the Middle Ages (with special regard to the territory of today's Slovakia) - Rímska kúria a Uhorské královstvo $v$ komunikačnej interakcii $v$ stredoveku (s osobitným zretelom na územie dnešného Slovenska). 
"Städtische Pressburger Zeitung", August 10, 1832, Carl Angermayer, Pressburg (Bratislava), 1764-1929.

\section{Bibliography}

Bartušková M., Společenská předškolní výchova v době vzniku našich prvních opatroven, [in:] Kapitoly z histórie materského školstva na Slovensku, Bratislava 1970.

Bartušková M. et al., Kapitoly z histórie materského školstva na Slovensku, SPN, Bratislava 1970.

Kasáčová B., Od detských opatrovní po predškolskú edukáciu, [in:] E. Gašparová, M. Miňová (eds.), Od detskej opatrovne k materskej škole. Zborník príspevkov, Banská Bystrica 2009.

Krajčovičová M., Rozvoj tvorivosti v súčasnej materskej škole, https://www.researchgate.net/publication/303899177 Rozvoj tvorivosti v sucasnej materskej skole Development of creativity in contemporary pre-school [access: 30.06.2018].

Levická J., Detské opatrovne, [in:] V. Hornáčková, D. Kollárová (eds.), Detská opatrovňa v Trnave a jej aktuálnost’ dnes, predškolská výchova ako výchova k harmónii, Pedagogická fakulta TU, Trnava 2002.

Mikleš J., Filantropizmus Márie Terézie Brunšvickej a zprávy slovenských časopisov o potrebe zakladat' detské opatrovne v 19. storočí na Slovensku, [in:] Sborník pedagogického inštitútu v Banskej Bystrici II, Bratislava 1964.

Mikleš J., Rehlingenovo pedagogické pôsobenie v detskej opatrovni v Trnave, [in:] Sborník pedagogickej fakulty v Banskej Bystrici VIII. Pedagogika-Psychológia, SPN, Bratislava 1966.

Mikleš J., Vývoj idey predškolskej výchovy do obdobia založenia prvých verejných ústavov predškolskej výchovy, [in:] Sborník pedagogickej fakulty v Banskej Bystrici. Pedagogika-Psychológia, SPN, Bratislava 1966.

Pill F., Trnavská detská opatrovňa v rokoch 1832-1863, Ročníková práca, Trnava 1961.

Ristovska R., Brunšvikovci a ich život v Dolnej Krupej (Sonda do problematiky), [in:] Historické rozhlady, Wydawnictwo i Drukarnia Towarzystwo Słowaków w Polsce, Kraków 2012.

Šimončič J., Detská opatrovňa v Trnave v rokoch 1832-1863, [in:] Mojej Trnave. K dejinám Trnavy a okolia, Trnava 1998.

Šimončič J., Vývoj a archívna charakteristika fondu detskej opatrovne v Trnave, [in:] V. Michalička et al., Dejiny predškolskej výchovy na Slovensku, Zborník Múzea školství a pedagogiky, Bratislava 1999. 
Ivan Podmanický* (D) https://orcid.org/0000-0003-2312-5095

Trnava University in Trnava

https://doi.org/10.25312/2083-2923.16/2019_06ip

\title{
Pedagogical love and prosociality in school education in Slovakia
}

\begin{abstract}
Ethical education has more than a twenty-year-long tradition in Slovak education and still evokes discourse both in the professional community and among lay public. Therefore, alongside with practical measuring of efficiency of prosociality, research activity is focused on examination of ethical, philosophical, anthropological, psychological and pedagogical foundations of social relationality with regard to contemporary valid conception of ethical education in school education in Slovakia. Since the notion of prosociality is relatively unknown in the philosophical-educational discourse, the submitted paper offers several ideas on connection between prosocial behaviour and moral-philosophical thinking. At the same time, it briefly discusses the importance of presence of pedagogical love in education while implementing prosociality in contemporary school education in Slovakia.
\end{abstract}

Keywords: pedagogical love, responsibility, education, ethical education, prosociality

\footnotetext{
* Ivan Podmanický - works as an assistant professor at the Department of Educational Studies of the Faculty of Education of the Trnava University. His research deals with the issues of didactics of ethical education, teacher's personality and matrimoniagogics. In addition to direct pedagogical activity, he also devotes to postgraduate forms of teacher education. He is the head of the attestation committee for the $1^{\text {st }}$ attestation in the category of teacher and the Central Subject Committee of the Slovak Republic for the ethical education. He is the author or co-author of monographs and publications, for example: Man to Man. Toward the Sources of Ethical Education (2016); Tradycja uspołecznienia w wychowaniu personalistycznym o orientacji społecznej we wspótczesnej edukacji słowackiej. Uspołecznienie jako droga człowieka ku człowiekowi (2015); Prosociality and Ethical Education. Experience and Perspectives (2014).
} 


\section{Introduction}

Education is an example and love, nothing more.

F.W. Fröbel

In the course of human history, many thinkers have left a legacy of their understanding of the world to future generations. Not all of their statements have been of permanent validity and many of them seem to have been just bon mots in the given historical or situational circumstances. At first glance, even the idea of F.W. Froebel may appear rather simplified, however, in principle, it captures the value foundation of education in every historical epoch. Humans are creations of love and relationships and they need one another for meaningful existence. If we can see, even in the contemporary "post-educational era", the sense of pedagogical discourse in thinking about the essence and forms of the formation of human beings in connection with the reflection on the desired ideas of human character, thinking and action, then this idea should be part of the very core of pedagogical thinking and pedagogical life. attitude at all. That is why we should not lack the courage and ability to formulate an ideal of education that respects the image of man and the dimension of the holistic development of his personality. ${ }^{1}$

Education needs to have the anthropological paradigm clearly defined. The development of understanding of a person in the modern times proved that love and relationality are necessary for every human being and their destruction brings destruction to values and thus, for a human being, it is dimension conditio sine qua non. ${ }^{2}$ As Rimbaud, the Damned Poet, put it, love has to be "reinvented"; it is not sufficient to protect its status quo. Human beings live in a primarily personal world, in which they create personal relationships with one another and, thus, participate in the development of social relationships. They do not lose their individuality in these relationships, on the contrary, they confirm and realise it. Each person is original and unique in their bodily, spiritual and character structure. As an open being they need love for the completion of human creation. The relationship to the Other enables people to form the dimension of their own 'I', with a corresponding moral self-awareness that can be examined only from the entirety of personal relationships representing the "...ethos of a certain society, its culture and religion". ${ }^{3}$ According to Frankl, love is "the final and the highest thing that a human being may achieve" and "...it makes a person prescient," adds M. Scheler. ${ }^{4}$

${ }^{1}$ M. Strouhal, Teorie výchovy, Praha 2013; I. Podmanický, Teória a prax etickej výchovy 1, Trnava 2012.

2 I. Podmanický, Z. Podmanická, Absencia „communio“ pri dospievaní, "Studia Scientifica Facultatis Paedagogicae" 2017, Vol. XVI, No. 3, pp. 7-16.

${ }^{3}$ M. Mráz, Východiská a zmysel výchovy, [in:] Etika a etická výchova na školách, Trnava 2002, p. 39; T. Špidlík, Duchovní jednota Evropy, Olomouc 2007.

${ }^{4}$ P. Tavel, Zmysel života podl’a V.E. Frankla, Bratislava 2004, p. 88. 
Love as the base of each personal relationship is the greatest discovery that originated in the Judeo-Christian religious tradition. As the fundamental motivation source for formation of relationships, it is awaiting its complete realisation. Once human beings do not see a person or a thing that they care for and see only themselves, they do not have a motive for self-realisation, which appears as a consequence of fulfilment of meaning. The German word for meaning comes from the Old German word sinnan ${ }^{5}$, which means to wander, go, head somewhere, attempt something. Humans need motive on their life journey. Similarly, the same holds for the desire for happiness. Happiness, too, needs a motive. If humans care only for happiness, they lose the reason to be happy for. Happiness should not be the finality of our efforts, but rather its accompanying phenomenon, a consequence. It can be stated that happiness is demonstration of a well-lived life. ${ }^{6}$

The illusion of the French revolution that only an educated human, freed from superstitions, can be happy was shown to be false and at the end of the $20^{\text {th }}$ century it was replaced by the illusion of consumption that saw realisation of happiness mainly in unlimited saturation of one's own needs. This moment was manifested also in interpersonal relationships, when focus solely on oneself brought the postmodern human being a feeling of loneliness, alienation, because relationships were overmaterialised, overrationalised and "pragmatically" aimed at using or abusing. The absolute desires of human beings cannot be fully saturated by education, wealth or power. If they do not implicitly include a "higher idea" from the perspective of needs, they have significant limits, they can even project a pathological perception of power or wealth. For "...neither a person nor a nation can exist without some higher idea" (F.M. Dostoyevsky).

We can be happy due to relationships that we establish and experience at a vertical and horizontal level. Anthropos, in his verticality, is capable of an "upward view", leaves his secure place (securitas), gets to know the world and transcends it through his view, stands on his own feet and as a being in via in the role of a wanderer searches for his journey. Legs are one of the hallmarks of a person that highlight their ability to communicate and create new paths in their horizontality through communication to connect with other people, which is the basic presupposition of establishment of each communion.?

In the process of identification, human beings are able to recognise and establish basic relationships to themselves, to the Other, to the world, to transcendence, which is a natural demonstration of a trichotomy structure of their being. Acceptance of $x e$ nos (difference) of the Other emerges from the need to establish positive relationships with the Other (affiliations) but at the same time, it emerges from the condition to

${ }^{5}$ A. Grün, Kniha otázok a odpovedí, Trnava 2010.

${ }^{6}$ V.E. Frankl, Hladanie Boha a otázka zmysłu, Bratislava 2009.

${ }^{7}$ I. Podmanický, Etická výchova ako súčast školskej edukácie v polarizovanej spoločnosti, [in:] J. Kaliský, Dobro a zlo, alebo o morálke I, Banská Bystrica 2013. 
cope with the alien, unknown, different (alienus). The alien, however, is something that can lead not only to carefulness or rejection, but also fascination (fascinum) and acceptance as something attractive. The anthropological-personalist approach confirms that the ability to love and the need "to be loved" are deeply rooted in human nature to "be a person" in his/her spiritual and social being heading toward absolute future. ${ }^{8}$

Without love, as B. Vysheslavtsev puts it, a person would be satanic, which has been certified by the past several times. To be a person in his/her essence means sharing, willingness to live, self-actualisation and doing all the good that one is capable of. Thus, love is not focused only on itself, on the contrary, it eliminates egoism. The evil of egoism does not reside in the fact that humans value themselves too much, attribute themselves unconditional importance and eternal value, they are right; it resides in the unjust denial of this importance in others. ${ }^{9}$ Plessner emphasised that humans are reasonable beings, however, they are immeasurable, open, having certain weaknesses, which constantly force them to look for a new relationship to themselves and the Other, to the world and the Absolute. ${ }^{10}$ The personal character of an individual emerges precisely from these relationships. The extent to which human beings handle their path, what they fill it with, depends on the conditions they have grown up in. They may live in a barren environment, knowing only fear, lack of interest, carelessness and indifference, or they may live in an educational environment respecting specific rules, full of stimuli and interest in others, filled with an atmosphere of empathy, understanding and love.

The contemporary generation of children is often marked by the educational straying of their parents and teachers who do not know how and what to lead them to, or what vision of life they should help to show them. These elements are also transferred to educational institutions. Many school facilities (including faculties of education) are not the place of real education and preparation of pupils and students for life, understanding of the world and searching for their place in it (nevertheless, university education has a specific purpose). Parents do not only bring their children to life, but also to the world, i.e. regarding education, they are responsible not only for the life and healthy development of a child, but also for the continuation of the world they are connected to. At the same time, as a matter of paradox, unless he/she is ready, a child needs to be protected from this world in a traditional family environment. Once a human life is exposed to the world without protection of his/her intimacy, privacy and safety, his/her vitality is lost. ${ }^{11}$

${ }^{8}$ A. Rajský, I. Podmanický, Človek člověku. K prameňom etickej výchovy, Trnava 2016.

9 V.S. Solovjov, Zmysel lásky, Bratislava 2002; I. Podmanický, Etická výchova ako cesta človeka k človeku, [in:] P. Vacek, D. Vrabcová, M. Maněnová (eds.), Výchova k dobru, Hradec Králové 2016.

${ }_{10}$ M. Mráz, Problém utrpenia a jeho riešenie v medicínskej etike, Trnava 2000; H. Rotter, Osoba a etika, Brno 1997.

${ }^{11}$ H. Arendtová, Krize kultury. 4 cvičení v politickém myšlení, Praha 2004. 
Teachers should take into consideration that a child is for them an alien, unready human, new in the world and, at the same time, in the process of formation. However, the task of a teacher is not to provide manuals on how to live, but to teach a child to get to know the world. School should not replace the world, or family; it should be an institution that assists children in the transition from the family environment to the world. Parents and teachers, through the way and quality of education, demonstrate whether they love the children so much that they do not cast them off from the world, do not leave them without any help and give them a chance to create something new in this world. ${ }^{12}$ Therefore, usefully, one of the basic principles of education is the unity of educational environments and cooperation of family and school. Both environments differ from one another in their importance and corresponding tasks, but both need to bear in mind the good of a child and, thus, they need to be filled with love and tactfulness. Love cannot be demanded, it must be given freely. Then, it is honest, unselfish and sensitive. On the outside, it is represented by tactful behaviour. A child is a creation of love, rituals, touch; thus, they need contact for their healthy development. Based on the original Latin equivalent 'taktus' - touch ${ }^{13}$, it can be metaphorically stated that while working with children, it is important to "touch them sensitively" not only physically, verbally, but also by our overall approach ${ }^{14}$. "Wild honesty" is not an optimal expression of tactfulness.

\section{Pedagogical love in ethical education}

The notion of pedagogical love has disappeared from contemporary educational discourse and a part of the professional public considers it inaccurate, vague, misleading, non-scientific and impossible to be implemented in educational conditions. For example, a German pedagogical dictionary states that the subject word pedagogical love is pre-scientific, even non-scientific in the contemporary period of professionalisation, scientification and planning of education. However, pedagogical love should not be abandoned unless we want "...education to become an unkind formation" ${ }^{15}$ It is not easy to capture love in notions, but it has an irreplaceable place in educational practice and pedagogical theory. Among other things, school does not mean only an institution with a building and material equipment, where pupils and students achieve a certain degree or type of education. Pupils cannot be perceived as material that we process according to our view, but as unique living beings having their

12 Ibidem.

${ }^{13}$ In the past, it was understood as a quality of caregivers who while working with seriously ill patients, had to touch them very carefully so that it hurt them the least while positioning them on a bed, for instance (T. Špidlík, Vatikánske promluvy s humorem, Olomouc 2010, p. 126).

14 The overall approach is understood as a selected type of educational style of a teacher or a parent.

15 W. Bohm, Wörterbuch der Pädadogik, Stuttgart 1988. 
life story, longing for discovery of themselves and the world. Every child wants to be discovered and assured that they are special and needed for this world. Therefore, it is possible to say that school means foremost people. In its environment, the power field of the relationship teacher-pupil is created, which is one of the key moments influencing education. Discussing education, relationships are discussed; discussing relationships, time is discussed. Every education is carried out in specific relationships and these are carried out in specific time and space. And this is not possible in an unkind environment.

"In the experience of great love," Guardini wrote, "everything becomes an event in its environment" ${ }^{16}$ If pupils experience it from their teacher, it affects their performance and relationship to the given subject or the environment positively, but also, they handle seemingly unsuccessful situations more easily. They learn to accept failures as a part of their life journey. In such understanding, pedagogical love relies on reason and its specific manifestation is kindness. Reason determines the strategy that needs to be followed and kindness indicates its tactics. Reason fulfils the function of the highest regulation principle. It is not only an organ of knowledge but a faculty that leads to morality. On the other hand, kindness helps to create interpersonal relationships and harmonious, efficient communication. ${ }^{17}$

In Slovak education, one of the subjects that can hardly be carried out without love is ethical education. It was included in school education in Slovakia in $1992^{18}$, aiming at aiding a young person in their preparation for life and relationships, and the development of generally accepted values and principles (dignity of humanity, respect for life, etc.) connecting people of different opinions or confessional orientation. At the same time, it had an ambition to offer specific models of behaviour together with its role models. There is an advantage of role models presented in this way; we do not have to personally agree with the religious views of, for example, Mother Theresa, A. Schweitzer, M.L. King or M. Gandhi, but their behaviour may be attractive for every unbiased person. The power of ethics is assessed by the behaviour of the saints, not the foolish ones 'cuius deus venter est.'.

The Slovak conception of ethical education did not emerge, in contrast to other pedagogical projects, as an outcome of the long-term systematic experience of a research team, but as a result of existential need. Socialism left behind disruption both in the economic and moral field. Therefore, after the "Velvet Revolution" in 1990, at the then Ministry of Education, Youth and Physical Education of the Slovak Republic,

${ }^{16}$ L. Guissani, Riziko výchovy, Praha 1996.

17 R. Sarka, Nadčasovost' v Pascalovej apologii, Košice 2006, Vol. XVII, No. 1; I. Podmanický, Etická výchova..., op.cit.

${ }^{18}$ Ethical education was included as a compulsory 'optional' subject in alternation with religious education at first only at the lower secondary level of primary schools. At present, it is taught in all grades at primary schools and in the first two years at secondary schools.

${ }_{19}$ [Whose God is their belly]: U. Eco, C.M. Martiny, V čo verí ten, kto neverí?, Bratislava 2015, p. 113. 
an expert group led by Ladislav Lencz was created whose mission was to terminate the socialist deformations in the field of school education and to search for foundations for new conceptions of educational initiatives. The output of these efforts was the creation of a conception focused on development of prosocial behaviour - the conception of the subject Ethical education ${ }^{20}$ that L. Lencz built on four mutually interconnected elements - vision, educational program, methods and style of education. ${ }^{21}$ The mutual dependence of individual elements is illustrated in the following scheme ${ }^{22}$ :

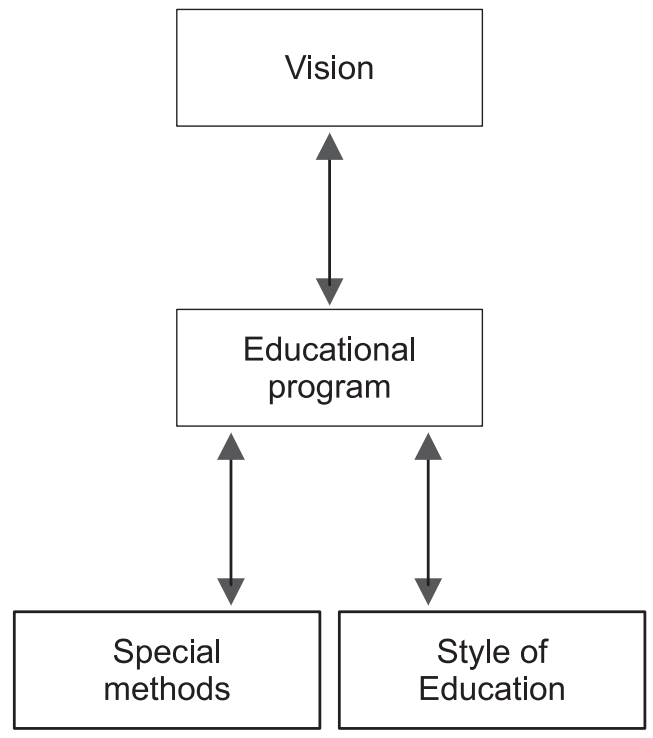

Figure 1. Components of ethical education

Source: Krížová, Podmanický Etická výchova - výchova k prosociálnosti... ${ }^{22}$

The vision of ethical education is a prosocial human who is morally mature, assertive, communicative, creative, emphatic, cooperative, able to perceive the interests of others and has healthy self-esteem. So that this vision may come true, it is necessary to have a certain knowledge and basic skills (educational program), which is supported by the teacher's approach to pupils (style of education) and selected

${ }^{20}$ Members of the expert group carried out an in-depth analysis of tens of theoretical and experimental works focused on character education and moral development of an individual. Studies by E. Staub, P. Mussen, N. Eisenberg-Berg, D. Bar-Tal, V. Battistisch, D. Solomon, K. Ryan and R. Roche-Olivar proved that prosociality is significantly statistically related to a great range of positive personality features such as higher level of empathy, assertiveness, quality communication, creativity, self-control, patience, respect to the Other, responsibility for one's self and others.

${ }^{21}$ L. Lencz, Metódy etickej výchovy, Bratislava 1993.

${ }_{22}$ O. Krížová, I. Podmanický, Etická výchova - výchova k prosociálnosti. Študijný materiál pre pastoráciu mládeže, Bratislava 2001, p. 2; I. Podmanický, Teória a prax..., op.cit. 
methods through which the pupils develop moral judgment and necessary social skills (special methods).

The vision of prosociality implies not only education of an individual but also the establishment of a cooperating community within a social group. A community, communion, adjective form communis (mutual, common, biding), core of the word munia - responsibility, burden, task ${ }^{23}$, enables a child to mature socially, to prepare both for the establishment of his/her own communion (family) and to acceptance the "burden" and responsibility of involvement in the communion of public life.

The very notion of prosociality is relatively new, not anchored in many scientific disciplines yet. The first authors who independently of one another introduced the term prosocial behaviour to psychology were D. Rosenhan and G. H. White. ${ }^{24}$ From the etymological perspective, the base 'pro' means in front of (something), a place in the front or in front of someone in the sense of protection or good in favour of the other. The second part of the word - 'socius', 'socia' has several equivalents of meaning, such as companion, helpmate, coparticipant, ally, i.e. someone who is allied to someone else..$^{25}$

From the vertical perspective, prosocial behaviour represents a level of benefit that it brings to a recipient or the entire social group. Therefore, many authors ${ }^{26}$ included it in the space of antinomic dynamics as an antithesis to antisocia ${ }^{27}$ behaviour. Prosocial behaviour has three inter-related levels: cooperative, helping and altruistic. ${ }^{28}$ While characterising the notion of prosociality, the view of the other human, who we see in them, is therefore important. For example, someone who is dependent on us, or we need them, or threatens our interests, or they need something, or they are important to us, fulfil us with something. Thus, we hold them for a rival or a partner, companion and ally, with whom it is/is not worth establishing social bonds. ${ }^{29}$ From this perspective, it is possible to understand prosocial behaviour as behaviour that brings benefit (good) to another person (group) that is not motivated by duty (deontological ethics), nor affection (teleological ethics) but by an unselfish care for the good (benefit) of the Other (altruism). Good is not a dead notion, it has its specific

\footnotetext{
${ }^{23}$ F. Novotný et al., Latinsko-český slovník, Praha 1955.

${ }^{24}$ M. Mráz, Problém utrpenia a jeho riešenie v medicínskej etike, Trnava 2000.

${ }^{25}$ F. Novotný et al., op.cit., pp. 314, 472.

${ }^{26}$ E.g. J. Reykowski, Smoleňka, J. Křivohlavý, E. Staub, R. Roche, and others.

${ }^{27}$ Antisocial behaviour - behaviour aimed against social subjects even at the cost of breaching legal or moral norms.

${ }^{28}$ I. Podmanický, A. Rajský, Prosociálnost' a etická výchova. Skúsenosti a perspektívy, Trnava 2014.

${ }^{29}$ In addition to the well-known definitions by R. Roche, E. Staub, P. Müssen and N. Eisenber-Berg, L. Páleník, L. Lencz, etc., each emphasising a different dimension of prosociality (an interesting and necessary one), the author of the paper inclines to the view that, in general, prosocial behaviour is understood as behaviour aimed at help in favour of other persons or groups or social aims without the actor of the behaviour getting outer reward (M. Brestovanský, A. Rajský, I. Podmanický, Prosocial education project implemented in the Slovak Educational System, Paper presented at the 14th European Congress of Psychology, 7-10 July 2015, Milan).
} 
compendious content denoting the essence of what is dignified, honourable and precious (in the natural and transcendental sense). Its value grows with our awareness of urgency, fullness and richness of the given situation. In the words of T. Aquinas, we may say that good is what is reasonable and essential to be done right here and right now. ${ }^{30}$ This moment is also reflected in teaching ethical education. Its vision and processual side imply a process of education, formation and training aimed acquisition of virtues. The basic principles that are a necessary part of teaching ethical education are illustrated in Figure 2.

Respecting these principles is crucial for the meeting of I and Thou. ${ }^{31}$ The difference of the Other is uncovered in a dialogical community, where others let us know themselves in a "space" of mutual acceptance and respect. The Buberian idea that "relationship is mutuality" 32 is an unconditional inclination to the Other with an unconditional moral value. It is dialogical "mutuality" in which a better understanding of a partner in a dialogue as a person in their sovereignty and dignity is born. A dialogue is not understood as a polemic concurrence, it is rather a clarification of standpoints aimed at a better understanding of the Other. A human being is a dialogic being who does not become anything and is not in a monologue. Confrontation is not a dialogue. A good dialogue is a path to understanding because it assumes an effort for mutual understanding and respect, and an acceptance that we might be wrong and the Other might be right. Metaphorically speaking, from the perspective of philosophy (even though through etymologically imprecise understanding of the notion dia-logos), the truth and meaning of life need to be sought and understood through speech (dia - two persons talk to each other - processual side) and word (logos). Then it may be assumed that dialogue will be an expression of interest in the Other, their opinions and attitudes. ${ }^{33}$

${ }^{30}$ R. Guardini, Dobro, svedomí a soustředování, Praha 1999; Dojčár, [in:] I. Podmanický, A. Rajský, Prosociálnost'..., op.cit.

${ }^{31}$ M. Buber, Já a ty. Praha 2005, pp. 38-39.

${ }^{32}$ Ibidem, p. 48.

${ }^{33}$ J. Poláková, Smysl dialogu. Praha 2008; I. Podmanický, Z. Podmanická, Absencia..., op.cit. 


\section{Principle of love}

\begin{tabular}{|l|l|}
\hline $\begin{array}{l}\text { Prosocial } \\
\text { orientation }\end{array}$ & $\begin{array}{l}\text { Ability to express solidarity, } \\
\text { equality and realise acts of love }\end{array}$ \\
\hline & Principle of freedom \\
\hline $\begin{array}{l}\text { Offering prosocial model } \\
\text { of behaviour and values }\end{array}$ & $\begin{array}{l}\text { Developing authentic } \\
\text { and creative personality }\end{array}$ \\
\hline
\end{tabular}

\section{Principle of communiocentrism}

Creating educational community
Active engagement in community

\section{Principle of respect to human}

Child as a bearer of image of authentic humanity

Complex development of child's personality

\section{Principle of moral-educational unity}

Mutual unity in the spirit of prosociality

Cooperation in mutual respect between teacher - pupil; pupil - pupil; teacher - parents

\section{Principle of congruence}

Living in accordance with accepted values and norms
Congruent behaviour in community and private life

Figure 2. Principles of teaching ethical education 


\section{Conclusion}

The development of prosociality as a vision of ethical education, including an appropriate pedagogical-psychological application, is one of the effective ways encouraging the development of personality, its intellectual, ethical and religious abilities, as well as moral thinking, which positively influences the establishment of valuable interpersonal relationships. Research on the education of pupils toward prosociality ${ }^{34}$ proved positive changes in the overall atmosphere of educational community, in both pupils' and teachers' behaviour. It also proved the importance of a positive relationship between a teacher and pupils. Prosociality encouraged a positive relationship to the taught subject and the preferred model of behaviour. More than 25 years of empirical and research experiences implementing ethical education in Slovakia suggest that one of the key pillars of effective implementation is the art of pedagogical love. Essentially, it is an art that can be learned, which should be respected by pedagogical theory.

Love (SK: láska; PL: miłość) and kindness (SK: milost' PL: łaska) are not just mirror images of perception of the notions in the Slovak and Polish languages, where the Slovak meaning of love means kindness in Polish and the Polish meaning of love means kindness in Slovak. These are two mutually interconnected terms that carry deep symbolism not only in a theological sense but also at the natural human level. Even if love is understood as one of the fundamental constituting elements of human beings, and even if human beings crave it, it is not possible to enforce it, it is a gift, kindness, voluntary act or manifestation from the other person. Something that was given to a human being without their credit because they are loved for their essence.

The basic fundament of realisation of kindness is love. If we do something for others from love and solidarity, we give them kindness; and if someone acts like this for us, we are given kindness. This fact applies not only in common situations but also in stressful ones (e.g. in case of violation of rules). Then, kindness looks at what can be done with the guilty person - enable the development of a better human through education. That is why, once pupils experience manifestations of love and kindness from their teacher (parent), they feel accepted, their self-respect grows, they learn to open themselves to others, become aware of their own "transgressions" and learn to correct them. They are preparing to establish their own relationships. In present relationships, a teacher educates pupils for their future relationships.

Love, kindness, respect for others are not archaisms that do not belong to modern pedagogy. On the contrary, the more structured and complicated social and cultural life is, the greater the need for love, kindness and respect in families and educational

${ }^{34}$ For example, in 2014-2018, Department of Educational Studies, Faculty of Education, Trnava University has been carrying out research focused on the development of prosociality of pupils at primary schools. The course of research and results that have been obtained so far are processed in publications: I. Podmanický, A. Rajský, Prosociálnost'..., op.cit. and A. Rajský, I. Podmanický, Človek človeku..., op.cit. 
institutions. For a teacher (parent), respect for a human being from the first moments of his or her creation is not just a general feeling, but is acceptance of responsibility for the creation of a specific human being. Then, it may be assumed that the pupil will be led to fulfilment of a triad, formulated by J. A. Comenius, "know - act - want (love, choose)".

The paper was supported by the VEGA grant No. 1/0557/16.

\section{Bibiography}

Arendtová H., Krize kultury. 4 cvičení v politickém myšlení, Praha 2004.

Bohm W., Wörterbuch der Pädadogik, Stuttgart 1988.

Brestovanský M., Rajský A., Podmanický I., Prosocial education project implemented in the Slovak Educational System, Paper presented at the 14th European Congress of Psychology, 7-10 July 2015, Milan.

Buber M., Já a ty, Praha 2005.

Eco U., Martini C.M., V čo verí ten, kto neverí?, Bratislava 2015

Frankl V.E., Hladanie Boha a otázka zmysłu, Bratislava 2009.

Grün A., Kniha otázok a odpovedí, Trnava 2010.

Guardini R., Dobro, svedomí a soustředování, Praha 1999.

Guissani L., Riziko výchovy, Praha 1996.

Krížová O., Podmanický I., Etická výchova - výchova k prosociálnosti. Študijný materiál pre pastoráciu mládeže, Bratislava 2001.

Lencz L., Metódy etickej výchovy, Bratislava 1993.

Mráz M., Problém utrpenia a jeho riešenie v medicínskej etike, Trnava 2000.

Mráz M., Východiská a zmysel výchovy, [in:] Etika a etická výchova na školách, Trnava 2002.

Novotný F. et al., Latinsko-český slovník, Praha 1955.

Podmanický I., Etická výchova ako cesta človeka k človeku, [in:] P. Vacek, D. Vrabcová, M. Maněnová (eds.), Výchova $k$ dobru, Hradec Králové 2016.

Podmanický I., Etická výchova ako súčast' školskej edukácie v polarizovanej spoločnosti, [in:] J. Kaliský, Dobro a zlo, alebo o morálke I, Banská Bystrica 2013.

Podmanický I., Rajský A., Prosociálnost' a etická výchova. Skúsenosti a perspektívy, Trnava 2014.

Podmanický I., Teória a prax etickej výchovy 1, Trnava 2012.

Podmanický I., Podmanická Z., Absencia „communio“ pri dospievaní, “Studia Scientifica Facultatis Paedagogicae” 2017, Vol. XVI, No. 3, pp. 7-16.

Poláková J., Smysl dialogu, Praha 2008.

Rajský A., Podmanický I., Človek člověku. K prameňom etickej výchovy, Trnava 2016. 
Rotter H., Osoba a etika, Brno 1997.

Sarka R., Nadčasovost’ v Pascalovej apologii, Košice 2006, Vol. XVII, No. 1.

Solovjov V.S., Zmysel lásky, Bratislava 2002.

Špidlík T., Duchovní jednota Evropy, Olomouc 2007.

Špidlík T., Vatikánske promluvy s humorem, Olomouc 2010.

Strouhal M., Teorie výchovy, Praha 2013.

Tavel P., Zmysel života podla V.E. Frankla, Bratislava 2004. 


\title{
Andrej Rajský ${ }^{*}$ (iD) https://orcid.org/0000-0002-6899-9231
}

Trnava University in Trnava

https://doi.org/10.25312/2083-2923.16/2019_07ar

\section{Love as absolute challenge - also for education}

\begin{abstract}
The other (alter), through the lens of Levinas's criticism of the same (neutrum), is always a unique other who stands up to any generalisation and homogenisation. According to a heteronomous schedule of ethics by E. Levinas, "face of the other", presence of their personal Thou in the sphere of life of a moral subject, precedes own being of this subject by their calling for an answer. Uniqueness of interpersonal relationship and appeal of the exterior Thou challenges human to exclusivity and to infinite self-abandonment in favour of the other (challenges to love). This ethical horizon is not possible to be ever reached and closed, it is impossible in fact, too difficult to be accepted as a norm of everyday life, mainly life in a community, society, state. Presence of "the third" (the political) in the sphere of morality is posed as a theoretical problem: What kind of ethics should be designed in a society of many "others" where Thou is inevitably turned to $\mathrm{He} /$ She, included in socio-political structures and relationships of justice? Is it possible to talk about some continuum between the relationship to the other and the relationship to a community? The final part of the paper seeks to answer these questions and pedagogical implications of demands of love in moral education are pointed out.
\end{abstract}

Keywords: E. Levinas, ethics of the other person, philosophy of dialogue, moral education, love

\footnotetext{
* Andrej Rajský - Assoc. Prof. PhDr. Andrej Rajský, PhD. (Department of Educational Studies, Faculty of Education, TU in Trnava) - associate professor of pedagogy, focused on philosophical-ethical and anthropological areas of research and education. He published Osoba ako ikona tajomstva. Príspevok $k$ personalistickej antropológii (Person as an Icon of Mystery. Contribution to Humanistic Anthropology) 2007; Nihilistický kontext kultivácie mladého človeka. Filozoficko-etický pohlad (The Nihilistic Context of Shaping up a Young Man. Philosophical-Ethical View) 2009. He co-edited, together with B. Kudláčová, Európske pedagogické myslenie (od moderny k postmoderne po súčasnost' (European Educational Thinking (from Modernism to Postmodernism up to Present)), 2012, two books with I. Podmanický: Prosociálnost' a etická výchova. Skúsenosti a perspektívy (Prosociality and Ethic Education. Experiences and Perspectives) 2014 and Človek človeku. K prameňom etickej výchovy (Human to Human. On the Sources of Ethic Education) 2016 and with M. Wiesenganger: Pomoc druhému na ceste cnosti. K filozoficko-etickým aspektom prosociálnosti (Helping others on the
} 


\section{Introduction}

Love has various meanings and its scope is necessarily polysemic. For the purpose of this article, all relationships, acts and attitudes of charity, giving, care, support, help, altruism or prosociality are considered as relationships of 'love'. It is love 'as such', as an anthropological and ethical phenomenon, that constitutes the humanity of people. The intention of this study is to philosophically examine the moral dimension of acts of love, acts of good-doing to 'the Other', that is, acts of specific help, care and love devoted to the unique Other. Therefore, in this article the theme of love is directly connected to the theme of the relationship to 'the Other', which gives rise to questions like: Who is the Other? What does his or her subjectivity in regard to the loving person and their morality, in particular, mean? How does the very existence of some Thou bind to responsibility for them? Questions of this kind are understood as an inseparable part of inquiring about the essence of love. In this paper, significant attention is devoted to the issue I and Thou based on the philosophy of dialogue, in particular. In this perspective, the Other human being is the one 'opposite me', always a living, unobjectifiable and infinitely transcendental challenge for a specific and ungeneralisable relationship of respect.

Here, however, the problem of the exclusivity of the Other, expressed by the following questions, emerges: If Thou is unique and infinitely transcending all my possibilities of fulfilling their demands, does it not call for my isolation from the world and society? Does not the appellative of the Other urge me to neglect 'the other Others'? These questions open up the issue of the social and political dimensions of prosociality and they are examined in the context of the morality of justice.

The second level of the research is represented by the level of education, which is approached particularly from the point of view of moral education. Since the prosocial act (act of giving one's self) is examined from the perspective of the realisation of one's own potentiality and intentional development, the main aim is to examine the mutual position of two facts: the morality of a person as a protagonist of the giving act and the possibilities of a person`s growth through this unselfish act. Both poles of this relationship (personal and practical-educational) will be examined through the lens of the philosophy of dialogue and the ethics of virtue, in which a deeply existential, interior, even ontological dimension of morality and development of an individual is strongly emphasised. This view enables us to see if and to what extent an act of love to the Other is understood as a substantial part of the realisation of a person, their 'path

Path of Virtue. The Philosophical and Ethical Aspects of Prosociality) 2018. In 2019, he co-edited the book Education and "Pädagogik". Philosophical and Historical Reflections. He is the member of the presidium of the Central European Philosophy of Education Society (CEUPES), member of editorial board of several Slovak, Czech, Polish and Italian scientific journals on philosophy of education, editor-in-chief of the journal Scientia et eruditio and scientific guarantor of annual doctoral conferences on educational science Juvenilia Paedagogica. 
of virtue', path of self-development. Based on this aim, we philosophically ask what role is played by the development of one's own moral character in the development of a prosocial (non-egoistic) setting of a shaping person and, on the contrary, if the 'face of the Other', which binds me to responsibility and care, has a direct connection with the cultivation of virtue. At the pedagogical level, the question is posed as follows: Is there a relevant connection between education to prosociality and development of character? Or, briefly: Does a helping act change the morality of a person, et vice ver$s a$, does moral maturity of a human being strengthen their readiness to help?

In order to answer these questions, I decided to deepen selected aspects of the ethics of dialogue, while bearing in mind the dynamic aspect of approaching the Other.

\section{Who is the Other?}

The philosophy of dialogue, which intersects with personalistic philosophy and ethics, was chosen as an inspiring source of reflection on the relationship to the Other and the authenticity of helping love. Particularly, the focus is on Emanuel Levinas's ethical conception. A quotation by $\mathrm{H}$. Arendt aptly illustrates the content connection between personalism and Aristotle's understanding of friendship: "Love in the broader sphere of human affairs corresponds to a personal relationship that may be best described as 'respect'. Respect is like the Aristotelian philía politiké, a sort of 'political friendship' that does not require proximity and intimacy. This relationship is an expression of respect for a person." 1

Civic friendship is a virtue of broader co-existence, in which respect for the Other person is a cultural condition for the pursuit of a good life. However, this quality of co-existence with others in a community has its origins in an elementary relation to the Other, the close one, a specific Thou, with whom I develop a deep and unique story of friendship. The basic relationship between I and Thou is an operative symbol, an effective sign and a starting point for all positive social relationships, marked by the nature of unity, generosity, respect and mutual responsibility.

It seems that the outlined continuity between the relationship of I-Thou and politiké philía is apparent and it does not need to be proved. However, this aspect gets problematic when the following question is analysed in depth together with Levinas: Who is a friend, a neighbour, the Other, to whom I turn my goodwill? Who is the Other? The Other is above all different than I and at the same time, different to everything else. Levinas understood that, in the identification of the Other, their existence needs to be differentiated from 'the same', the entire, anonymous, total and general being (there is, Fr.: il y a) that covers everything with its non-differentiatedness and impersonality. When we turn to the Other, we turn to an 'alien', to something and someone that does not belong to the familiar, obvious, one's own country domi-

\footnotetext{
${ }^{1}$ H. Arendtová, Vita activa neboli. O činném životě, Praha 2007, p. 316.
} 
nated by me. An active movement to the Other suggests a movement 'elsewhere', outside one's self, into terra incognita in the strongest meaning of the word. "The Other we metaphysically crave for, is not 'Other' like the bread I eat, place I live in, country I dwell in, like sometimes I am for myself. [...] Metaphysical desire heads toward something completely different, absolutely different" 2 . The desire for the Other is not based on a need, since a need is a state in which a human person lacks something, i.e. they are incomplete, thus, they are existentially nostalgic for something they at least partially know in advance (the Other as an alter ego). However, the metaphysical desire does not crave for a return, but for something completely different, something we have never contained. If we talk about love as of saturation of some noble hunger, then it is not real love. Real love longs for something that transcends every fulfilment and deepens the desire itself further. It is a desire for the radically heterogeneous. Realisation of this existential desire paradoxically increases the distance between us, since it reveals authentic exteriority, difference, unicity of each Thou. The difference of the Other is the difference of the noble, the highest, the infinite, the invisible. The metaphysical desire for the absolutely Other 'presupposes unselfishness of goodness'3.

Does it mean that radical separateness of the Other can cast us into solitary confinement? That non-transferability of 'the Other' to 'the same' condemns our existence to eternal isolation, slavery of the 'teeming' totality of being (there is)? Levinas shows that such a fatal fate would await a human being if that being were a primal state, a gift of the vicious world in which we as subjects would suddenly find ourselves. According to him, on the contrary, the shapeless teeming, the anonymous depth of a night ${ }^{4}$ are not primal. A unique relationship is 'not the being' (Germ. Sein) of the existent (Germ. Seiende), but the relationship to someone who is the existent. Ontology is not primal, ethics is. Ethics means questioning the spontaneous egoism of 'the same' by the presence of 'the Other'. "The strangeness of the Other - their irreducibility to Me, my ideas and my possession - occurs as questioning of my spontaneity, as ethics." The transfer of the Other to the same is then the essence of immorality. To know ontologically is to surprise in an existent confronted that by which it is not this existent, this stranger, that by which it is somehow betrayed, surrenders, is given in the horizon in which it loses itself and appears, lays itself open to grasp, becomes a concept. Conceptualisation means the suppression and appropriation of the Other, a power transformation of the Other to the Same. Cogito (eng.: I think) finally means 'I can' (meaning 'I have the power to state'), that is, depredatory appropriation of what is. Ontology is actually philosophy of power, it is 'egoistic', impersonal, inhuman, without respect to dignity and, eventually, it is unjust because it violently transforms the Other to the Same. The opposite of neutralisation is transcendence, confirmation of

\footnotetext{
${ }^{2}$ E. Lévinas, Být pro druhého, Praha 1997, p. 19.

3 Ibidem, p. 21.

${ }^{4}$ E. Lévinas, Existence a ten, kdo existuje, Praha 1997, p. 47 and further on.

${ }^{5}$ E. Lévinas, Totalita a nekonečno, Praha 1997, p. 28.
} 
'to be different' in the person of the Other. Relationship to the Other, by definition, is not reversible. Its mutual changeability would connect I and Thou to one system (We) that would destroy the radical difference of the Other. Transcendence to the infinite is the only possible ethical relationship to the Other. The very radical difference of the Other, however, is possible only when Thou is the Other in the relationship with an element whose essence remains a starting point, it serves as an entrance to the relationship. This element that remains at the starting point of the relationship is I.

What does it mean to be I? In particular, I means to have an identity, or rather, to be in a process of constant finding of one's own identity across everything that happens to it. I is the original self-creation of identification. It is identical in its transformations, it has a structure of a subject, the first person. I blends with itself, it is the same against all difference, it cannot abandon 'itself', it is not someone else. Identification of 'the same' in I does not occur as clear tautology 'I am I' (as A=A), but as a result of existing here at home with oneself, in the way of dwelling, that is, like at one's home ${ }^{6}$. I am at home in the world, because the world offers (things) or resists (persons) my ownership. Ultimately, the encounter of I and the irreducible diversity of Thou creates the subjectivity of I.

How does the ethical relationship, the relationship of transcendence to the Other take place if its aim is not adjustment, the establishment of the collectivity We? Is such a relationship to Thou possible in which its radical exteriority against I would be kept at the same time? If an authentic relationship cannot be a representation, since the Other would dissolve in the Same, the Other needs to be accepted as different, that is, the distance suggesting difference of the Other needs to be kept. Their difference precedes every initiative, every imperialism of the Same. I and the Other do not create a number, the collectivity I-Thou is not the plural of I. "To accept the Other means to accept their hunger. To accept the Other means to give. But to give to a sovereign lord, the one we address 'You' in the dimension of Majesty"7. If the Other is to be preserved in their inviolability, I cannot exercise my power, which I exercise over the world, over them. What is the possible nature of the relationship to the Other? Levinas replies that it has the nature of a dialogue. The dialogue, however, cannot be explorative, revealing, but purely relational, it should be immediate revelation, manifestation of sense, presence that cannot be reduced to intellectual opinion. In a dialogue, I comes out of its ipseity, beyond every totality, like face to face. This movement, however, is by definition irreversible. I performs it as a breaking movement of transcendence, not as thinking of the Other but as one's own conative walk. When I finds itself in a dialogue with Thou, it assigns the Other a right over my egoistic being and apologises for it. Egoistic thinking resides in speaking and adopting an ethical attitude to the Other in responding to their call or revelation. The Other manifests themselves to the first

\footnotetext{
6 Ibidem, p. 23.

7 Ibidem, pp. 59-60.
} 
one, reveals their face, their presence. "The face speaks. The manifestation of the face is already discourse. He who manifests himself comes [...] to his own assistance. He

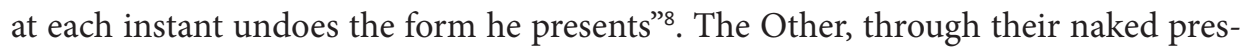
ence, calls, begs, requires. It is the look of a stranger, widow and orphan. Encounter with the Other is a shock, their silent face causes upheaval and challenge. It evokes in I consciousness of unique responsibility, it is a permanent and unfulfillable challenge for the unstoppable I so that it attempts to cross the abyss to the separated Thou. Subjectivity of I is fully created only after acceptance of this challenge, taking the position of responsibility to the Other.

Levinas, in his works, attacks Heidegger's fundamental ontology and shows that he betrays the Dasein (the Other, Thou) in favour of the indifferentiable totality of impersonal being ${ }^{9}$. Heidegger wanted to awake humanity from the sleep of forgetfulness about being, however, he did it at the cost of forgetfulness about the Other. As J. Lacroix states, "for thinking smitten with unity pluralism is embarrassing." 10 According to Heidegger, being human is from the very beginning co-being (Mit-sein), 'being with the Other'. However, it is not a dialogical co-being, the relationship between I and Thou is missing. The Other/different is constantly reduced to 'the same' in sameness and non-differentiatedness of We. Superficial sociability of human beings looks for fusion as an ideal state, and Heideggerian Miteinandersein (being-with-another) is the collectivity of 'friends', an effort for symmetry ${ }^{11}$. Against the collectivity of persons standing 'side by side', Levinas places the collectivity of persons standing 'face to face'. Morality does not stem from the consciousness that we are together 'on the same side' but from the acceptance of the Other so that they take priority over me. The word of the Other, their appeal, determines ethical existence of I. I is in a way 'promised to the neighbour, it is chosen to them. Responsibility for the Other is a unique expression of love to neighbour.

Being human is from the very beginning 'being-for' (Für-sein), being because of the Other, being-for-the Other. 'To be for the Other' is existentially binding, the Other is not beside me, they are in front of me, standing opposite me. My responsibility is not an expression of my freedom, it is not preceded by my generous decision, on the contrary, the responsibility binds me even before my freedom, it precedes it. The chosen (every moral subject) cannot escape it, its moral action has a heteronomous origin. Everybody is 'hostage to their brother'. The status of a moral subject resides in its passivity, in acceptance of the primary challenge. Here, the paradox of an authentic relationship of love is shown: the loving one is actually passiens (the suffering one, the non-active one, a patient) who is affected by the address of the Other. "Happiness

${ }^{8}$ Ibidem, p. 50 (in English version, 1991, p. 66).

${ }^{9}$ Cf.: E. Lévinas, Existence a ten, kdo existuje, Praha 1997b, pp. 30-31; E. Lévinas, Totalita..., op.cit., p. 52.

${ }^{10}$ C. Chalierová, O filosofii Emmanuela Lévinase, Praha 1993, p. 7.

${ }^{11}$ E. Lévinas, Existence..., op.cit., p. 79. 
and peace are not the true measure of humanity. The human in a subject is awakened when instead of the statement 'I am', the subject responds to the calling of the Other 'here I am'"12. The Biblical adsum ('here I am', 'I am ready', 'I am available') takes the meaning of Für-sein here. Ethical asymmetry of the Other to me, their infinite challenge, forbids the setting of peace and happiness as the final ideal of life because being is preceded by an extreme concern for the Other, some moral obsession that does not allow me to settle and rest. The ethical appeal of the Other is not based on examination of 'what is' but thirsty heads towards to 'what should be'. The challenge of responsibility for the Other is infinite, it can never be fulfilled. According to Levinas, the Other relates to me and their face calls for me even if they are not concerned for me, even if they do not know me at all. "I have increasingly more responsibility than the Other, I am responsible even for his responsibility"13. Here, educational responsibility can be sensed: if I am responsible for responsibility of the Other, I take over the mission to encourage and develop in the Other responsibility for every Thou that appears in front of the Other. This mission, in the right sense a mission to listen, is the teacher's mission.

If altruism is understood as the will of a human to be good (helpful, well-meaning, generous) to the Other, then Levinas's ethics is not an ethics of altruism because according to it, I do not decide about good, on the contrary, good fascinates me and captures me. If I see a face, I hear the commandment 'Thou shalt not kill!'. The face is truly naked, vulnerable, exposed to possible violence. The notion of murder includes all forms of violence, such as contempt for the Other, their denial, either by acting, speaking or thinking. For Levinas, the commandment 'Thou shalt not kill!' is the essence of revelation, everything else is just its consequence.

Thus, in Levinas, no virtues can be identified as learned behaviours. Moral dispositions, which are a prerequisite for good action, are never explicitly mentioned in the terminology of ethics of virtue, especially if we mean its majority interpretation, according to which 'good character features' are related to the person of the bearer as the owner.

The philosophy of metaphysical desire for fulfillment (which never takes place) and its realisation through responding to the call of the Other resembles rather Kantian deontologism, except that this desire is not determined by the autonomy of will but by the heteronomy of the face of the Other. Instead of the imperative of a universal moral law that commits, commands and forces, in the ethics of encounter with the Other morality is determined by the appeal of responsibility, which unconditionally binds by the heteronomous law 'Thou shalt not kill!'.

If Kant's ethical concept deals the term 'virtue' as a disposition of a moral subject to act in accordance with an objective coercive principle ${ }^{14}$, Levinas's ethics would, for

\footnotetext{
${ }_{12}$ C. Chalierová, op.cit., p. 27.

13 Ibidem, p. 31.

${ }^{14}$ I. Kant, Základy metafyziky mravů, Praha 1976, pp. 41, 70.
} 
such disposition, call openness to the Other, willingness to acknowledge own commitment to them, readiness to accept responsibility for them. The acts of recognition of the Other (reverence), respect for their uniqueness, responsibility (non-indifference), care for their lack, unconditional giving (high-mindedness and generosity), acceptance of the Other in their exteriority (patience), love (non-violence), justice (non-abuse of power) would be then included in the register of 'acts of virtue'.

\section{And what about the Others?}

In the introduction, a question was posed whether it is possible to conceive 'prosocial' ethics of 'many Others', whether some continuum between the relationship to the Other and the relationship to a community exists. In socio-political structures and relationships providing justice, the distant Other ceases to be Thou and inevitably turns into $\mathrm{He} / \mathrm{She}$, blends with totality of the general. Levinas labels this problem as the problem of the so-called 'third ${ }^{15}$. Radical moral responsibility for the unique Other results in a practical issue: how to live (ethically) well in a situation of plurality, physicality, sociality, normativity and the political aspect of a human being? How to transfer the ethics of giving and exclusive love to the Other in the world of society, i.e. everyday life with social and professional relations and tasks with prosaic rules and norms? Co-existence with many takes place in the field of securing justice through agreements, contracts and political consensus regarding the will of the majority. In the original collectivity I-Thou, there is no majority, the requirement of relationship is absolute, it demands involvement of the entire human being. The impossibility that it would refer to the 'other Others', to 'every Other', to 'the Other in general' is even more evident.

Levinas clarifies how it is possible that a radical requirement of 'the third' appears in the centre of exclusivity of the relationship of I and Thou. Everything that takes place 'between us' (I and Thou) is related to everybody, and every observing face is standing in the light of public order, even in the case of a private and secret relationship.

Speech as a relationship of the presence of a face is not a challenge for some self-sufficient consociation, forgetting about the universe. "In the eyes of the Other someone third is staring at me - speech is justice [...] The poor one, stranger presents themselves as the one who is equal to me. Their equality in this essential poverty depends on the fact that it refers to the third who is present in an encounter like this and whom in their lack the Other already serves" 16 . The Other is never alone in the relationship to me, I need to take responsibility over the third one, who is next to them. I even need to choose between them, ask who has priority and who needs to be protected. And thus, the epiphany of the face of the Other is a lordly command to me

\footnotetext{
${ }^{15}$ E. Lévinas, Totalita..., op.cit., p. 189.

${ }^{16}$ Ibidem, p. 188.
} 
that 'orders me to command. "The presence of the face - of the infinitely Other - is the lack, the presence of someone third (that is, the entire humankind that is watching us) and it is a command ordering to command" ${ }^{17}$. The Other orders me to care for the order of justice, public morality and good institutions for their sake. 'The command ordering to command' is a pedagogical challenge: The Other asks me to cultivate social and political relationships, structures and agencies of power, even to establish and demand normative order for the sake of the Other. My activity of the care for 'the third' is an activity of cultivation, refinement and shaping of Others (children, youth, pupils, students) who currently and prospectively create the order of justice. Moral education focused on authentication of the relationship I and Thou is inseparable from education to respect for social normativity that provides justice.

It does not hold, in a society, that the innocent never suffer. The Other asks me for justice, mediated by rules. It is not sufficient to teach morality without institutions. A moral subject is forced to descend from heaven to earth, their moral tools and customs that they developed in the collectivity I-Thou need to be reviewed and adapted to life in collectivity with 'the third'18.

In any case, just institutions are those that listen to the requirements of the Other, respect heteronomy in which the Other calls us and challenges as. The transition to political order is a transition from love to justice, but to justice respecting the requirements of love. Ensuring such justice is a political task, or - as Levinas says - 'the wisdom of love'19. According to classical theories of the social contract (e.g. Hobbes), it is a matter of political wisdom to ensure the preservation of life and rights of individuals who are led to each other by natural egoism. These theories state that the most important value of human beings is assertion of themselves, development of their own personality. However, according to Levinas, the role of the political is not to limit the limitlessness of violence, but to limit the limitlessness of altruism. Generosity towards one Other could cause injustice somewhere else, to someone else, or even wrongs to someone third, whose voice I overheard or did not capture. "Love to the other cannot overlook the care for justice. Care means to compare the incomparable, to compare the other with the third one. In Levinas, this moment is the birth of the political"20.

The act of justice presupposes reduction of persons to measurable quantities, the act of abolishing the other as the Other and their conversion to the Same. Such an act - for the introduction of justice - implies violence, that is, the exercise of injustice towards the other. It is a paradox, however, it must not gain an inappropriate dimension in which the face-to-face position would no longer be possible. If that were the case, community would become totalitarian and would lose legitimacy. Community is legitimate when it allows the birth of communities in which fraternity can take

\footnotetext{
17 Ibidem, p. 189.

18 E. Lévinas, Etika a nekonečno, Praha 1994, p. 180.

19 Cf. C. Chalierová, op.cit., p. 32 and further.

${ }^{20}$ Ibidem, p. 34.
} 
place, that is, a situation where every person can become a face for me, get rid of anonymity and be close to me. Justice therefore must not become self-serving and insensitive to the uniqueness of every human.

The paper is an outcome of the project Vega No. 1/0056/19.

\section{Bibliography}

Arendtová H., Vita activa neboli. O činném životě, Praha 2007.

Aristoteles, Etika Nikomachova, Bratislava 1979.

Heidegger M., Bytí a čas, Praha 2002.

Chalierová C., O filosofii Emmanuela Lévinase, Praha 1993.

Chalierová C., Tři komentář $k$ filosofii Hanse Jonase a Emmanuela Lévinase, Praha 1995.

Kant I., Základy metafyziky mravi̊, Praha 1976.

Lévinas E., Být pro druhého, Praha 1997.

Lévinas E., Etika a nekonečno, Praha 1994.

Lévinas E., Existence a ten, kdo existuje, Praha 1997.

Lévinas E., Totalita a nekonečno, Praha 1997 (Totality and Infinity, Dordrecht/Boston/ London 1991).

Podmanický I., Rajský A., Prosociálnost' a etická výchova. Skúsenosti a perspektívy, Trnava 2014. 


\title{
Marek Wiesenganger* (iD) https://orcid.org/0000-0002-7274-491X
}

Trnava University in Trnava

https://doi.org/10.25312/2083-2923.16/2019_08mw

\section{Is it possible and necessary to cultivate love? Education to love according to "Summa Theologiae" of Thomas Aquinas"}

\begin{abstract}
The author researches the issue of love in Thomas Aquinas's Summa Theologiae. He researchs the possibility of upbringing for love, and from what point of view this education is needed. The author concludes that the concept of love is quite different in the Summa Theologiae. In the context of Aquinian ethics, virtue points out that friendly love, as a unique phenomenon of human beings, is not necessary and therefore not only permits but also requires it to be developed through education.
\end{abstract}

Keywords: participation, love, friendly love, education

\section{Introduction}

In the following text we are going to deal with basic anthropological resources of education to love from a philosophical point of view. We want to answer two sets of basic questions. The first one concerns the "possibility" of education: Is it in any way possible to bring up people to love? Isn't love, on the contrary, something what comes naturally with individual development? And if it is possible, what are the essential conditions of our human existence which support this possibility? Through the first question, we want to examine what is the possibility of upbringing to love, in other words, the degree of openness of a human being to education to love. The problem

\footnotetext{
Marek Wiesenganger doctor in pedagogical sciences, assistant professor at the Department of Educational Studies of the Faculty of Education of the University of Trnava in Slovakia. He deals with the philosophy of education, moral education and pedagogy. He is the co-author of the scientific monograph On moral education in national education in Slovakia in 1918-1939, as well as several chapters in scientific monographs on moral education and pedagogy.

1 This work has been supported by the Scientific Grant Agency of the Slovak republic VEGA under the Grant No. 1/0557/16.
} 
we are facing is to what extent is love in our "power". If we talk about education to something, every time there is a possibility to become someone, our development is not determined. Is it possible to consider love as some possibility or it is something that happens without the possibility of our choice? This was the first set of questions.

The second set of questions is focused on a different aspect of education to love. It relates to its key position in education. In fact, we ask if it is not only possible to educate to love, but if it is vital. Is this education necessary as something crucial in the development of love as the condition which enables one to develop love or is an upbringing to love only one of many ways in which to acquire love.

These questions form the formal side of this article. As is obvious from the title, our ambition is not to answer the questions generally. The text offers answers drawn from Summa Theologiae (Theological summary) - the last and unfinished work of medieval theologian and philosopher Thomas Aquinas (1225-1274).

It is necessary to outline the importance of Thomas Aquinas's thinking for contemporary philosophy, and for the philosophy of education. M. Ascombe's essay resulted in the aretaic turn in the field of philosophical ethics during the second half of the 20th century. Many authors engaged with this essay. One of them was A. MacIntyre, who was popular and respected but often criticised. His thinking developed and at some stage he engaged with and referenced the thinking of Thomas Aquinas. It is interesting to note that MacIntyre incorporated Thomas into his studies of Aristotle. MacIntyre suggests that Aquinas is more consistent with Aristotelian theory than Aristotle. It is not our task to evaluate the extent to which MacIntyre was successful in revealing Thomas's theory in its authenticity. More important is the fact that, although MacIntyre was part of the neo-Aristotelian movement, he argued that Thomas Aquinas was the key thinker of the ethics of virtue through an examination of the history of ethical thinking. Similarly, the philosopher and emeritus professor of philosophical ethics G. Abbà at Università Pontificia Salesiana also noted the importance of Thomas Aquinas. Abbà ${ }^{2}$ in his analysis of the evolution of Aquinas's thinking contends that Thomas Acquinas's Theological summary is the original synthesis in the theory about virtues and human deeds, in respect to other philosophers (e.g. Aristotle, Augustín, Albert Vel'ký). At the same time he points out that Aquinas's theory didn't have the final say in the history of ethical thinking. According to Abbà, Aquinas's synthesis remained uncomprehended by his followers and it was not discovered or appreciated until after the aretaic turn during the second half of the 20th century. Contemporary authors dealing with the ethics of care, the ethics of virtue or the education of personal traits refer to the work of Aquinas rather formally or only historically. We suggest that one of the reasons for the marginalisation of Thomas Aquinas's thinking is due

${ }^{2}$ G. Abbà, Lex et virtus, Studi sull'evoluzione della dottrina morale di san Tommaso d’Aquino, Roma 1983. 
to the scholastic and the neo-scholastic tradition which referred to Thomas Aquinas as a key thinker. According to Abbà, these traditions did not grasp some key ideas in their depth and consequences. This has resulted in a sort of simplified and schematic insight to Aquinas's work, which ignores major shifts in his thinking as well as his openness and dynamism which can provide inspiration for the present. According to us, this context is important to mention especially because of the current review of paradigms as modernism or trans-modernism and also hyper-modernism. All the mentioned traditions did not deal with the original thinking of Thomas Aquinas, but mainly with the scholastic and non-scholastic version. Thus, in this article we try to provide answers to the questions mentioned above about the possibility and necessity of education to love stemming from Summa Theologiae of Thomas Aquinas. We maintain that through an examination of the pre-modern concept we can contribute to a more developed view of the studied topic as well as broaden the horizon of the topic of education to love in the present.

In order to find the right answers to questions about anthropological conditions allowing education to love and the necessity of education to love, the answer to a basic question is needed: What is love according to Summa Theologiae?

In general, love in Summa Theologiae is seen as "a specific and unique movement of intellectual creation to God" (STh I, 2, pr.), the essence of which is the participation of human beings in the creation, and especially in relation to the Divine being. Aquinas's anthropological perspective is based on the fundamental premise of "potential perfection", or "initial imperfection" of every human being, who is gifted with the ability of development and changes to their potential into their developed forms. Thomas calls this development by movement (lat. motus) and indicates the fundamental process concerning the human being in its essence. In other words, and in the terminology of the classic tradition of the ethics of virtues, it is also about the way of acquiring beatitude, let us say the way of virtue, whose goal is "participation" in the highest goods, those which improve us to an unattainable extent and beyond the area of enjoyment and benefit. It is obvious that what Thomas indicates as a movement, doesn't relate only to the subjective and individual life of the human individual. On the contrary, the movement is basically linked to the principle of participation, thus participation in other existence. Movement and participation are two aspects of the same reality, while participation can be considered as one of the most critical principles of Thomas' philosophy, whereas beatitude as the fulfillment of human life is given by participation in the good, not only by the knowledge of the good, or the desire for the good. The connection of movement as the basic process of acquiring the full extent of humanity and participation in the surrounding existence points to the thesis of globality and integrity of being. It means that Aquinas is considering each being not only as isolated and absolutely autonomic in regard to other beings, but as ontologically linked and absolutely autonomic taking into account other beings. This 
mutual connection has its vertical dimension, thus a hierarchical arrangement, and a horizontal dimension. It means that the acquisition of perfection is dependent on the perfection of the other being, whereby particular beings are able to improve the being at a different hierarchical level in varying levels. In these contexts, it is necessary to point out that Thomas Aquinas considers being in its essence good in a double sense. First, kindness is given by actual existence, in fact, goodness is initial and original. Second, there is potential and perspective goodness, that is, goodness in its excellent and achieved state. This initial and perspective goodness of being is the basis for any being to be the means of the refinement of the other beings.

Considering the questions that we are trying to answer, it is important to point out that the aforesaid ideas find, in relation to a human being, their specific application mainly in the fact that the realisation of human potential happens through love, thus through participation in the good, which has the power to improve our givenness. We can say that the theory about love creates the gravitational centre of the theory about participation. Love as an acquirement forms the humanity of humans. In other words, the way of virtue, according to Thomas, is allowed by the dual-nature of the goodness of human nature as every human is being considered a good so his/ her "participation in the Divine goodness, but also by pointing to the good as to your goal"3. In this resolution the basic openness is placed. Human beings rely on goodness which can improve them because it makes real what is possible. The initial participation in goodness, which was given to humans by creation, forms the basis and borders to participation. Choice and goodness are discovered beyond the acting. This type of participation was realised through love. According to Thomas, human participation in God cannot reduce the relationship to a single person and God. According to Theological summary it is not possible to know God directly and imminently and as an eternal law inside us, but He is revealed to us only in His impacts (STh I-II, q. 93, a. 2, in corp. ${ }^{4}$ ) Equally, the way to perfect realisation of our own possibilities to be human leads through participation in God's impact. This has a decisive impact on all aspects of becoming a unique person. We can say that the way of beatitude, thus the way to realise the potential of being a human being is only via the correct participation in the goodness of the surrounding world. In the necessity of acquiring of one's own unique humanity every human being finds themselves as being essentially dependent on the world which surrounds them and other beings. The essential anthropological condition to realise one's own humanity, is openness and reliance of human beings on the good of other created beings. This is connected with the basic situation of love (lat. amor) to be the desirous appetitive (lat. appetitus) part of the spirit. It means that love "is the movement towards the subject outside the subject". It is fundamentally

${ }^{3}$ A. Blašč́ková, Etika cnosti podla Tomáša Akvinského, Nitra 2009, p. 14.

${ }^{4}$ T. Akvinský, O lásce a milosrdenství v Teologické sumě, Praha 2016.

${ }^{5}$ K. Šprunk, Tomáš Akvinský o lásce, [w:] T. Akvinský, O lásce. Výběr otázek z Teologické sumy, Praha 2005, p. 10. 
different from cognitive processes, which makes the acquaintance between united with the cognised object only in itself.

Thus, compared to cognitive processes, love is the principle (beginning) of the movement towards the beloved goal, from which desire arises as the movement to goodness and joy as a real connection to goodness. We can notice that love is the way of updating one's own potential, which Thomas termed adequatio. This term is often translated as "accordance", but from this is not adequate. Adequatio is a complex process, where Thomas indicates in the case of love three consecutive effects of good on appetite. The first one is a passive adaptation (lat. coaptatio) of appetite to goodness. Present goodness has the strength to activate inactive appetite. This activation means its initial change and contains some basic homogeneity (lat. connaturalis) with goodness and its adaptation (lat. coaptatio) to the form of goodness. The second following impact is the interiorisation of goodness, because an impression of goodness arises in the will (Lat. impressio) where in appetite rises the movement to goodness, comes tendency to a wanted thing (STh I, q. 27, a. $4^{6}$ ), which Thomas called falling in love (Lat. complacentia). The third and last impact of present goodness on appetite is unity between loving and loved. It is concerned about so-called affective unity (Lat. nexus), which Thomas differentiated from real unity. This unity means the transformation of diligence, which becomes homogenous in proportion to the present and desired good. Although in such love there is still no real unity with the subject of love, Thomas claims that affective unity is similar to a substantial one. Love in general (Lat. amor) is so called simply love, which creates the basis, the principle of every other love (STh I-II, q. 26, a. 3, in corp. ${ }^{7}$ ) In this context, we can clarify the causes of love: good, similarity and causality ${ }^{8}$. Good as the reason means that we can love only something that is appropriate, similar to our nature and that we have in the performance of what we have in potency (STh I-II, q. 27, a. $1^{9}$ ). Second, everything loves that which is in unity with it. This creates some colligation on the basis of similarity (STh I-II, q. 27, a. $3^{10}$ ). The third reason of love is knowledge. Although Thomas recognises the necessity of knowing good (STh I-II, q. 27, a. $5^{11}$ ), he defines that goodness comes first and that something could be loved more than it is known because it might be perfectly loved although it is not perfectly known (STh I-II, q. 27, a. 5, ad. $2^{12}$ ).

In connection with these three causes of love, it is clearly shown that Thomas's theory about love unfolds from the original, universal good of the world, in which every human specifically participates and has their own specific mission. Through

\footnotetext{
6 T. Akvinský, O lásce a milosrdenství v Teologické sumě, Praha 2016.

7 Ibidem.

8 K. Šprunk, op.cit.

9 T. Akvinský, 2016, op.cit.

10 Ibidem.

11 Ibidem.

12 Ibidem.
} 
love, people find the world homogenous with themselves, perceive the adequacy of the world which surrounds them, towards themselves. Love is the only cause of the movement of humans to goodness. Human beings, with their appetitive abilities, have the essential position to realise in the world. This reality is clearly shown in Thomas's distinction between demanding love (lat. amor concupiscentiae) and friendship (Lat. amor amicitiae) (STh I-II, q. 26, a. 4, in corp. ${ }^{13}$ ).. According to J. McEvoy ${ }^{14}$, Thomas placed the discussion of friendship (Lat. amicitia) in relation to the discussion of general love (Lat. amor) and to the highest form of love (Lat. charitas) in order to understand the form of friendship. Thomas defines friendly love as the form of love to another person, where goodwill (Lat. benevolentia) prevails on those forms of needs and desires which characterise passionate love. To love somebody else because of themselves means to respect and develop their unique nature as an independent reality and at the same time as a reality where we discover our "second self" (STh I-II, q. 28 , a. 1 , in $\left.\operatorname{corp} .^{15}\right)$.

Thomas highlights the distinction between demanding love and friendly love in an analysis of the effects of love (lat. effectus), distinguishing between the following effects: union, mutual indwelling, ecstasy, zeal and wound. In the most basic effect, union (lat. unio), Thomas reaffirms the original harmony and similarity of individual human beings, because on the basis that the two are similar, as if they are in one form, they are in this form somewhat unaltered. Therefore, the affection of one points to the other as to the one with which he is one, and wants him as good as himself (STh I-II, q. 27 , a. 3, in corp. ${ }^{16}$ ). For that, "each of these arises from a kind of apprehension of the oneness of the thing loved with the lover. For when we love a thing, by desiring it, we apprehend it as belonging to our well-being. In like manner when a man loves another with the love of friendship, he wills good to him, just as he wills good to himself: wherefore he apprehends him as his other self, in so far, to wit, as he wills good to him as to himself. Hence a friend is called a man's "other self" (STh I-II, q. 28, a. 1, in corp. ${ }^{17}$ ). This is directly related to the second effect of love, mutual residence (Lat. mutua inhaesio) between loving and loved. In friendly love comes specific mutual in-dwelling, where "the lover is in the beloved, inasmuch as he reckons what is good or evil to his friend, as being so to himself; and his friend's will as his own, so that it seems as though he felt the good or suffered the evil in the person of his friend. Hence it is proper to friends "to desire the same things, and to grieve and rejoice at the same"

13 Ibidem.

14 J. McEvoy, K recepcii Aristotelovského pojmu priatel'stva v scholastike, „Filozofia“ 2004, nr 5, p. 370 .

15 T. Akvinský, 2016, op.cit.

16 Ibidem.

17 Ibidem. 
(STh I-II, q. 28, a. 2, in corp. ${ }^{18}$ ). The third cause or a sign of true friendly love is so called ecstasy (Lat. extasis). Love causes ecstasy by two means: dispositively and directly. Dispositively in the case when it encourages knowledge beyond the cognitive; directly in passionate love where: "loving is entrained outside of themselves, joy from good is not enough for them they have and therefore they try to use some good outside of themselves. [...] Such a feeling ends in themselves or "in friendly love rises apart of them because they want and act well to their friend the way he cares and shows him the care because of themselves" (STh I-II, q. 28, a. 3, in corp. ${ }^{19}$ ).

It is evident from these three causes of friendly love that in the context of various forms of love friendly love is a unique movement of the soul for Thomas. Participation in good means that friendly love is a unique realisation of the abilities of our souls through virtues. The essential principles of friendly love include the fact that one human being who realizes their uniqueness can be good in a manner in which another person finds the way of their realisation. It is related to the ability of a human being who can recognise and realise good for another person. It means that humans are a unique creation who can develop the world which surrounds them at different levels and impact it in accordance with their own realisation. Love for another person can't be replaced by any other sort of good, where the person participates.

As we have shown, according to Thomas, passionate love as well as friendly love creates the essential movement of human beings who can achieve fundamental perfection. At the same time, it is love in which man tastes his own fundamental referral to the good, which is out of him. Because love is the unique reaction of human nature through which we are participants of good. Through love a given good improves, so actualising our own dispositions, potential.

Let us try to answer the first set of questions which asked if it is possible to bring people up to love or is love a movement rising out of our nature. It seems that the answer is ambivalent. It is clear that Thomas endows "love" with some natural movement, which is caused by the presence of good: spontaneous movement which doesn't require the choice of good or its recognition. In this case, it would seem that it is necessary to exclude the possibility of upbringing to love. All the aspects of love that Thomas develops through the theory about virtue are about the way to improve one's own nature, in other words, the change of one's own substance. On the one hand, we can accept that some type of love is a natural reaction to some aspect of the good of another being. On the other hand, it is necessary to take account of the fact that the presence of other beings doesn't have to be a coincidence and it is a possible targeted submission of selected human beings. In this case, we can talk about an intentional act

\footnotetext{
18 Ibidem.

19 Ibidem.
} 
in which one human focuses love at another human being - at the level of natural love. A person, who by intentionally choosing others, is able to change. This is the root of a unique type of good, which is not given to us by the only existence of being. Friendly love, which we are given by someone, is good, which is in its essence coincidental and accidental. But this doesn't mean anything other than that its existence has its own inception in a free act of another human. Accidentality means, that the act of friendly love is not necessary and determined. On the contrary, it is a true gift, because it arises from "nothing". For a better understanding, it is appropriate to point out the fact that, according to Thomas, beatitude is the fruit of virtue, which is nothing other than accident, including the essence of human being. But it mainly means that being virtuous is not necessary. It is just an option, which can remain unused. Therefore the act of friendly love, which can "wake up" our love, is that exact good, which is under our control. We can bless someone by it or retrieve them a specific good. Sure, the very love as an echo of spirit is not in this case of our power, but if it could be allowed to initiate the potential to be loved by friendly love, it is just possible to do it in the way through good created by friendly love. In this case, Thomas's thinking is inspiring as it always points out that love is always the answer to good and at the same time, the quality of love (demanding, friendly) is influenced by the quality of good.

The next area where we find roots for the possibility of upbringing in love is in the differentiation Thomas makes between various types of love. It seems to us that his understanding of acquirement of virtue is quite beneficial. If we ask what a virtue is, one of the answers is that it relates to an accidental form of substance. This means that it is quite stable (habitual) and at the same time an unnecessary (but accidental) change of our substance. The fact to which we want to draw attention is that this change is caused by a frequency and intensity of the presence of good which allows humans to recognise the given good and love in various situations. Thomas describes this process as "habitation". As G. Abbà always repeats, virtue is not a habit, but the ability to choose some good in the different contexts and conditions of outside and inside a character. So virtue is an ability to choose the better good, despite the presence of minor goods, which activate interest and love. This ability is not only necessary, but directly supposes conscious effort.

The second set of questions which we hoped to answer concerned the necessity of upbringing to love. Is upbringing necessary in the development of love as a condition, which basically allows love to be developed, or is upbringing in love one of many possibilities of earning love? Here too we can point to some ambivalence. There is a variety of love from the side of the loving, as well as from the side which is loved. We want to highlight the necessity of upbringing to friendly love. The necessity comes out of the problem of so-called random passions (Lat. passiones). It is obvious that love comes with various emotional states which are not bound only to a loved subject and the affects are rational or sensual. The variety of origin of these affective reactions is the 
source of variety in their spontaneity and intensity. For example, physically-sensitive affects are more direct, spontaneous than rational affects. This can cause a problem with the choice of good and it opens the demand for the development of such affective reactions which will be in harmony with the way of virtue. Upbringing to love would develop the ability to prefer that type of good which is in harmony with a good life despite its lower affective attraction.

\section{Bibliography}

Abbà G., Lex et virtus, Studi sull'evoluzione della dottrina morale di san Tommaso d'Aquino, Roma 1983.

Akvinský T., O lásce a milosrdenství v Teologické sumě, Praha 2016.

Akvinský T., O lásce, Výběr otázek z Teologické sumy, Praha 2005.

Blaščíková A., Etika cnosti podla Tomáša Akvinského, Nitra 2009.

McEvoy J., K recepcii Aristotelovského pojmu priatel'stva v scholastike, „Filozofia“ 2004, nr 5, pp. 366-378.

Šprunk K., Tomáš Akvinský o lásce, [in:] T. Akvinský, O lásce, Výběr otázek z Teologické sumy, Praha 2005, pp. 9-38. 
Yevgen Volodymyrovych Kulyk* (iD https://orcid.org/0000-0002-9410-6564

Poltava National University named after V.H.Korolenko

Yuriy Kulyk** (D) https://orcid.org/0000-0001-9403-2609

Kyiv National Economics University named after Vadym Hetman: Kiev, UA

https://doi.org/10.25312/2083-2923.16/2019_09yvyk

\title{
The problems of humanising technological education
}

\begin{abstract}
It is contended that technological education, forming the outlook of the modern-day person should accord to universal human values (the good, love, harmony, aesthetics, etc.). The achievements of scientific and technological advance should be subordinate to these values. It is argued that humanising the training of technology teachers requires a strategy and the establishment of regular courses in culture for technology teachers. It is suggested that humanising the paradigm of education changes the basic requirements of the dialectical method in revealing the contradictions of the object of study. Key ideas of pedagogy focus onthe uniqueness of each student and take into account her/his interests and values. This may require individualising the learning process. The abovementioned issues can be responded to through a cultural approach to technology teachers' training. The content of courses should recognise the integrity of the cultural experience of humanity: ethical, religious, philosophical, aesthetic, technical, professional, etc., in addition to the scientific way of knowing the world. The use of technology in everyday life has greatly increased. There has been a shift of cultural patterns from the realm of mass consciousness and mass behaviour that operate on a natural basis to new patterns characterised by individualisation, analysis, and even consciousness transformation and construction. Therefore, teaching that the technological culture of self-determination is culturally determined must be included in the cultural training of technologyteachers.
\end{abstract}

Keywords: pedagogy, didactics, technological education, humanising, cultural studies.

* Yevgen Kulyk - Doctor of Pedagogical Sciences, Professor, and Head of the Production Basics Department of Poltava National Pedagogical University named after V. Korolenko. The author of 100 articles, 4 inventions and 3 monographs. The main area of his research is the problem of youth's professional education.

* Yuriy Kulyk - Philosophy doctor, Associated professor, Kyiv National Economics University named after Vadym Hetman, Kiev, UA 


\section{Problem statement}

The current crisis situation ofsome post-communist societies requires changing priorities in education in order to imbue people with a new type of ideology. This ideology would fosteran individual's harmonious interaction with nature and with other people ${ }^{1}$, and would prepare such an individual toaccept global changes, respond adequately to the emergence of new knowledge and help him/her to orienthim/herself in the information space of today and in the future. ${ }^{2}$

An analysis of the current state of general educationin post-socialist countries has shown that one of the main reasons for the crisis in technological education is the existence of two contradicting paradigms in the formation of a modern person's ideology: scientifically-technocratic and humanist. ${ }^{3}$

In developed countries, these two paradigms complement each other informing the ideology of a modern person.

Therefore, the problem of analysing and developing the humanist paradigm of a modern individual's ideology in post-socialist countries is urgent, particularly in Ukraine.

\section{Analysis of recent research and publications}

The scientifically-technocratic paradigm refersto viewing society's future as being based on scientific and technological advance. Training in this paradigm leads to the formation of a technocratic type of personality.

The humanist paradigm privileges universal values (the good, love, harmony, aesthetics, etc.) as the basis for the ideological system of society. Science and technology aresubordinated to the ideas of humanism. ${ }^{4}$

Unfortunately, this controversy has not been overcome in Ukraine, and the education system continues to prepare future technology teachers within the scientific-technocratic paradigm. ${ }^{5}$

${ }^{1}$ National Center for Education Statistics, Yelektronniy resurs, http://nces.ed.gov/programs/ digest/d07/tables/dt07 005.asp.

${ }^{2}$ P. Belanzhe, Obrazovaniye vzroslykh $v$ promyshlennorazvitykh stranakh, „Perspektivy: Voprosy obrazovaniya”, UNESCO, 1992, № 4, p. 13-32

${ }^{3}$ S. Lutayv, Filosofiya suchastnoyi osvity - Navchal' Nyyposibnyk, Tsentr „Mahistr-S” Tvorchoyi spilky vchytel, 1996.

${ }^{4}$ V. Sidorenko, J. Kulyk, I. Zhernoklieiev, Updating Technology in the Comprehensive Schools of Ukraine. Technology Education in New Perspectives, Stockholm Institute of Education Press, Stockholm 2005, pp. 97-102.

${ }^{5}$ V. Kulykye, Pidhotovka maybutnikh vchyteliv do doslidnyts'koyi diyal'nosti, Kyyiv-Drohobych 2004. 
Thus, analysis of the information field of knowledge (the knowledge that a future technology teacher must possess, according to the typical curriculum) shows a significant bias favouring technical disciplines over the humanities. ${ }^{6}$

Analysis of the qualification characteristics of future technology teachers shows that in terms of «skills and abilities» there is a bias in favour of skills and abilities aimed at forming a technocratic person. ${ }^{7}$

At the same time, analysis of consumer goods (the final products of technological training), in which various technologies are integrated (for example, electronic equipment and automobiles) and which are manufactured in Ukraine, USA, Germany, Japan let us distinguish certain regularities in terms of price, quality, convenience and safety of operation, ergonomics, aesthetics, maintainability and utilisation.

Thoroughness and precision dominates in Japanese products, precision and rationalism - in German products, simplicity, maximum comfort and quality prevails in USA products. That mentality of the citizenry (which essentially depends on education) is clearly reflected in the final product through its characteristic features.

\section{Highlighting previously unresolved parts of a general problem}

An analysis of the curriculum and textbooks of these countries shows that significant attention is paid to more human-orientated knowledge. ${ }^{8}$ These are: ergonomics, design, culture of production, scientific organisation of labour, ecology. That is, the structure of professional knowledge, which has a significant human component, fosters the formation not of a technocrat, but a humanist.

A humanist personality gives preference to humanistareas of development in her/ his professional activity, in making decisions (choice of technologies, choice of work, choice of means of labour, waste management, and choice of safety equipment). So, if we focus on world standards of living, we need to foster the humanist educational paradigm in Ukraine (in the technology field).

The purpose of this article is to analyse the problems of humanising technological teachers' education.

\section{Presentation of the main research material}

Humanising the paradigm of education changes the basic requirements of the dialectical method in revealing the contradictions of the research object. The main contradictions that emerged from the contradictions of society for pedagogy in the past were: the contradiction between the needs of people and the conditions for their

\footnotetext{
6 Ibidem.

7 Ibidem.

${ }^{8}$ Ibidem.
} 
satisfaction, betweennormativity and creativity, between the typical training of teachers and the individual and creative nature of their activities. Nowadays, philosophers of education define the main contradiction of the pedagogical process as the ratio between satisfaction of social needs (what is the common "need") and the individual needs, the interests of separate students (what does a separate student "want"). ${ }^{9}$

Modern philosophers see the principle of solving this problem as the essence of a new educational paradigm. An analysis of the literature has shown that developing a new type of ideology, which ensuresharmony in society and with nature, requires significant changes in the assessment of science, its characteristics, and its main tasks. ${ }^{10}$ This idea was first expressed by the philosopher Vladimir Solovyov (so-called "unification theory"). His followers K.E. Tsiolkovsky, A.L. Chizhevsky, V.V. Vernadsky, and others, saw a new type of philosophy of education as interconnecting living and inanimate nature, the scientific study of nature and matter. And they called for the development of human ideology on the basis of the so-called new noosphere type of civilisation.

The use of the unification concept, while forming the methodological principles of systematising technological training content, will significantly eliminate the separation from values in our education, which has developed historically, based on philosophical and materialist principles. This concept must necessarily be used in the development of such areas of technological training as energy saving, maintainability, utilisation of waste products, which is determined by the culture of production, exploitation, consumption of both means of production and production facilities.

An analysis of the science literature showed that this great idea has not been fully implemented and has not led to technological learning out of a crisis, since the amount of knowledge that mankind possesses is not enough to cross the boundary on which the new paradigm begins. I mean the paradigm mentioned by T. Kuhn in The Structure of Scientific Revolutions. ${ }^{11}$

The modern transformation of the purpose of educational activity leads to a change in the tasks of education. The priority ideas of pedagogy are becoming theories aimed at studying the uniqueness of each student, taking into account his/her interests and value systems, which requires an individualised learning process. This, in turn, causes the rapid pace of development of knowledge of the previous paradigm.

Knowledge of a new paradigm often lags behind the development of science and technology, their unification reduces the dynamics of knowledge development. Regarding the training of future technology teachers, this problem is compounded by the fragmentation of the fundamental scientific knowledge in their technological training. Certain subjects such as heat engineering, mechanics, electrical engineering, materials science do not create "synthetic knowledge" (according to I. Prygozhin).

\footnotetext{
9 S. Lutayv, op.cit.

10 Ibidem.

11 T. Kuhn, The Structure of Scientific Revolutions, Publishing AST, 2001.
} 
It is possible to solve the above-mentioned problemspartly byadopting a cultural approach to teachers' training, that is, the content of the training should be the cover the cultural experience of mankind: ethical, religious, philosophical, aesthetic, technical, professional, etc., in addition to the scientific cognition of the world.

The culture-and-value reorientation of human beings and life should take place. And it must be realised in concrete social mechanisms of people's life orientation. Accordingly, training should focuson developing the personal potential of the learner. Culture does not act as an external illustration, but as a model of human existence.

Therefore, educational processes should not be based on a system of ready-made knowledge transfer, but on a system of learners independently acquiring knowledge, in the context of the formation of cultural values, ways of activity.

The peculiarities of socio-cultural processes in Ukraine determine the value-orientation and pedagogical and technological specificity of implementing the cultural paradigm in the training of technology teachers in the national school, but not its general civilization content. That is why teachers' preparation for professional activity requires an analysis of the current socio-cultural situation, the socio-philosophical justification of the parameters of the cultural approach for determining the content of training. At the same time, this analysis should take place in the context of the influence of general civilizational trends within the cultural and national environment of Ukrainian society.

Implementing the cultural approach in this regard is especially important in the process of professional training. During this process the value orientations of the younger generation are being set and the motivational basis for the solution of socio-economic problems is being formed. It determines the forms of activity of members of Ukrainian society in the 21 st century, including state building.

Unlike a traditional society, which is based on the processes of reproduction of activity, social structures, life rules and traditions, the modern dynamic society is characterised by processes of qualitative change of various social and cultural structures, as well as the correspondent forms of behaviour, thinking and consciousness of people. Assessment of the future changes accordingly. The future is a process of continuing the past in traditional society. In a dynamic society, the future is fundamentally different from the past; it must be redefined every time on the basis of newly created cultural values. In this case, the problem of the formation of a system of cultural values and motivation of each individual becomes very topical. That, in turn, actualises the cultural approach in the formulation of technology teachers' training.

After all, if earlier the life of society and the individual was determined by externally existing cultural patterns of behaviour and consciousness (mentality), then now the process of self-determination, self-identification, personal development of individual landmarks, ways of life, meaning of life and moral imperatives becomes more important. Nowadays, there is a fundamental change in the method of communication between those working in the technological sphere and those in culture. The exploitation 
of culture, the culture of consumption, the culture of using devices and products of production is growing. In traditional society, when technologies were quite primitive, the consumption of products occurred according to standards, cultural patterns. And the impact of technological culture provided for stability in social life. That is, culture, as a phenomenon was not distinguished as a separate social reality.

Within an information society implementing information technologies, the influence of the use of technology in the everyday life of individuals is increasing. Mass consciousness and mass behaviour operating on a natural basis has been replaced by individualisation, analysis and even conscious transformation and design. Learning activities should take place in the context of cultural values and help students pursue their life choices independently and constructively.

This approach brings forward new requirements for the system of future technology teachers training. In addition to the classical knowledge paradigm, which is focused on translating past culture, the goal of vocational training should include the problems of an individual's preparation for life in a constantly changing social environment through developing universal cultural-constructive abilities such as thinking, understanding, reflection, creativity, communicability, etc. That is, the competency approach becomes the key in professional personality formation. Transition to the information society forces us to reconsider the main paradigm of the training of future technology teachers from the transfer of well-known knowledge from generation to generation to the development of the ability to obtain information independently, to generate new knowledge independently, including the methods of receiving them; while perceiving them in the context of sociocultural, sense-of-life meaning that connects cognition with value orientations of the person in a social environment.

At the same time we have to take into account that the formation of technological culture should not be the ultimate goal of cognition, but it has to be a means that provides a deeper and more critical understanding of the current socio-cultural situation, as well as developing projects aimed at improving the various spheres of human life.

In this context, social actions becomethe criterion of value of a (wo)man (as capital), rather than the social status of the individual and, accordingly, society changes on the basis of the goals which are set and implemented by members of society. That is, if earlier technological education corresponded to the generalised demands of society as "scientifically substantiated objective necessity" then modern technological education should respond to the desire of an individual to be self-fulfilled.

Thus, in the context of modern social changes the understanding of the very phenomenon of culture changes. At the base of its structure is not so much a system of knowledge, as the way in which people seek and re-structure different information within the framework of value self-determination. Therefore, in the context of the cultural training of future technology teachers, the technological culture of self-determination in its own being as a culturally determined rationalisation must formulate the content of the corresponding professional training. 
One of the most important system-forming elements in the structure of the cultural training of future technology teachers is the ethical dimension of the human beingin the world. First of all, it is connected with a sharp growth of the potential responsibility of each person for his/her activity in the 21 st century, with a sharp increase in the possibilities of an individual to influence the direction and the content of social and cultural processes. The level of destructive impact by mankind on nature has reached an unprecedented scale, and the social environment of human existence is also being destroyed. This makes humanity rethink our relationship with the natural and social environment. The result of this rethinking is the noosphere approach, which fosters the consideration and regulation of planetary problems, in which human beings will consolidate a set of processes in the natural, social and technical world into a single whole. The role and significance of interpersonal communication is increasing in terms of the progressive interdependence of people, and the morality of another person becomes a condition of my freedom and life's success. The ethics of non-violence is being formed as a principle of survival not at the expense of other people, but due to mutually beneficial cooperation. However, again, we should keep in mind that the ethical dimension of human activity is possible only on the basis of the implementation of a cultural approach to the organisation of all social life as a criterion basis of social values.

Therefore, the new humanist paradigm for future technology teachers' training involves the introduction of such subjects as ergonomics, design, production culture, consumption culture, waste management culture into the educational process. It is necessary to carry out the development of new technologies, devices, tools, materials on this basis.

\section{Bibliography}

Belanzhe P., Obrazovaniye vzroslykh v promyshlennorazvitykh stranakh, „Perspektivy: Voprosy obrazovaniya", UNESCO, 1992, No. 4, pp. 13-32.

Kuhn T., The Structure of Scientific Revolutions, Publishing AST, 2001.

Kulykye V., Pidhotovka maybutnikh vchyteliv do doslidnyts'koyi diyal'nosti, KyyivDrohobych 2004.

Lutayv S., Filosofiya suchastnoyi osvity - Navchal' Nyyposibnyk, Tsentr „Mahistr-S” Tvorchoyi spilky vchytel, 1996.

National Center for Education Statistics, Yelektronniy resurs, http://nces.ed.gov/programs/digest/d07/tables/dt07 005.asp [acessed: 12.08.2019].

Sidorenko V., Kulyk J., Zhernoklieiev I., Updating Technology in the Comprehensive Schools of Ukraine. Technology Education in New Perspectives, Stockholm Institute of Education Press, Stockholm 2005, pp. 97-102. 
Anna Sarbiewska* ${ }^{\text {(iD }}$ https://orcid.org/0000-0002-9429-8228
independent researcher

https://doi.org/10.25312/2083-2923.16/2019_10as

\title{
Visible Learning and educational policies in New Zealand and Australia
}

\begin{abstract}
This article analyses the theoretical background of changes that have taken place over the last two decades in the Australian and New Zealander educational systems. That background has two elements: first, understanding of pedagogical activities performed by the teacher and students in the educational process has been modified, second, Hattie's concept of Visible Learning has gained a following. The text consists of four sections. The first section presents a reconstruction of the traditional model of perceiving the actions of teaching and learning. In the second section an insight into the foundations of an innovative, evidence-based approach to education is provided. The following section describes the concept of Visible Learning in relation to the main determining factors of education. Finally, the last section describes some of innovations introduced in New Zealand's and Australia's educational systems which, it is argued, raise the effectiveness of educational practices there.
\end{abstract}

Keywords: traditional education concept, evidence-based teaching, Visible Learning, education, system of education, New Zealand, Australia.

\section{Introduction}

Education and its management system require constant reform. This is not only due to the changing political situation, as one might think, looking at the reality in Poland, but also due to the problems that the public education system must face. Out

* Anna Sarbiewska - MA in English Philology (UWM 2005). Teacher at the Jan III Sobieski Secondary School in Szczytno since 2003. Teacher of pedagogical practice (Zespół Kolegiów Nauczycielskich in Szczytno 2003-2009), English language teacher (ZKN in Szczytno 2005-2008), chartered teacher, secondary school-leaving and eighth-grade-leaving examiner (OKE in Łomża). She was awarded the Medal of the National Education Commission (2017) and distinction in British Alumni Society "Teacher of the Year 2016" competition. In her research she focuses on the culture of education functioning in Polish schools, the possibilities of its modification, teaching and learning activities and their correlation; e-mail address: anna.sarbiewska@loszczytno.edu.pl. 
of many problems, one of the most important is guaranteeing students the conditions for real learning at school, and not just spending time (many years!) more or less voluntarily in it. This task forms the basis of public legitimacy of the education system and the school as an institutionalized space for teaching and learning. Understanding this issue should also be at the heart of decisions regarding education reforms. The changes that have been introduced for many decades in New Zealand and Australia prove, in my opinion, the raising public awareness, what is the main problem of education and the search for ways to solve it. The starting point of the longstanding changes in the 1980s was the focus on insufficient use of educational research data. Pedagogues and researchers recognised shortcomings in 'using a combination of privileged and tacit knowledge of the context, political savvy, professional training and logical analysis. Data played almost no part in decisions. ${ }^{1}$ New Zealand and Australia stopped omitting research and data and started to base education policy on the results of educational research. Policy makers and educators reviewed the existing way of thinking about the tasks of the education system and the whole attention was directed to education and its quality derived from research. In 2003 New Zealand's Education Minister, Trevor Mallard put a new emphasis on quality teaching and said it would be a priority in his programme to improve student achievement. Nowadays all minor and major decisions at school or government level are taken after in-depth analyses of facts and data received from education research. I believe that tracing the processes that took place in Australia and New Zealand will benefit us to think about Polish education, its strengths and weaknesses. ${ }^{2}$

In this article I will present changes in the education system not by analysing particular education programmes but by referring to two models of teaching and learning - a traditional and modified. This is due to my interest in the essence of change and not particular modifications which took place in New Zealand and Australia. In the first section I will sketch a traditional model that can be easily compared to the pre-reform period. The following section provides an insight into foundations of an innovative evidence-based approach to education. The third part of the article sheds light on factual constituents of education process and their interaction according to the modified teaching and learning model. The fourth part presents New Zealander and Australian methods of education improvement by integrating Visible Learning with the system of education. Conclusions illustrate ideas on how Poland may follow effective and proven education practices.

${ }^{1}$ L. Earl, S. Kat, Leading Schools in a Data-Rich World, https://www.researchgate.net/publication/252669674 Leading Schools in a Data-Rich World.

2 D. Klus-Stańska, Dlaczego szkolna kultura dydaktyczna się nie zmienia, "Studia Pedagogiczne" 2011, t. LXIV, pp. 43-50. 


\section{Traditional understanding of education}

I suggest looking at the changes in New Zealand and Australia mentioned in the introduction through the prism of traditional model of education. Traditionally teaching is perceived as a process planned outside the school by policy makers and carried out in the same way by all the schools. The main aim of educators in this model is to prepare students for external exams so that they obtain high results. Schools compete with each other and fight for the best position in ratings, which are later published in newspapers and widely discussed in the media. According to Geoff Masters, Chief Executive of the Australian Council for Educational Research, teaching in the pre-reform was based on

[...] the delivery of the appropriate year-level curriculum to all students. Under this view, the role of teachers is to deliver the relevant curriculum; the job of students is to learn what teachers teach; and the role of assessment is to establish how well students have learnt what teachers have taught and to grade them accordingly. ${ }^{3}$

The process of schooling is simplified to an assumption that 'teaching' equals 'learning. Dariusz Stępkowski, following the German pedagogue Dietrich Benner, points out that such traditional understanding of education as 'forming', 'shaping' or 'bending' can be well illustrated by the following figure of the didactic triangle in the classic version. ${ }^{4}$

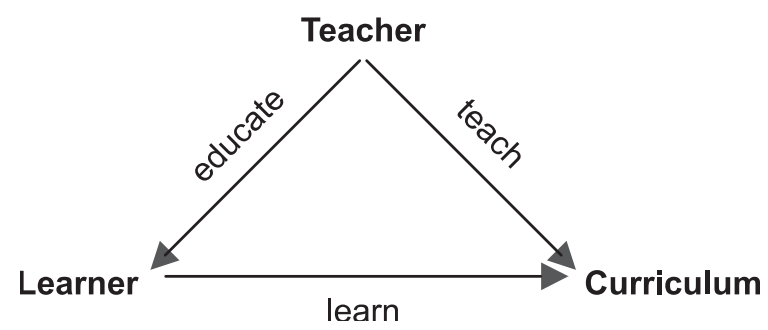

Figure 1. Didactic triangle in the classic version

Source: D. Stępkowski, Kształcenie jako dobro pedagogiczne i źródło nierówności edukacyjnej (in print).

The 'Curriculum' plays the key role in the above-mentioned construction. It focuses on the Teacher's activity - 'teaching', and the Learner's - 'learning.' According to this mapping, education is understood as a transfer of knowledge and skills between the person who has them and the person who should master them. The action 'edu-

${ }^{3}$ G. Masters, The Role Of Evidence In Teaching And Learning, https://www.teachermagazine. com.au/columnists/geoff-masters/the-role-of-evidence-in-teaching-and-learning.

${ }^{4}$ D. Stępkowski, Kształcenie jako dobro pedagogiczne i źródło nierówności edukacyjnej (in print). 
cate' creates a separate kind of pedagogical interactions ${ }^{5}$, which are loosely connected with the concepts prevailing in education - teaching and learning, or are not connected with them at all. The above structure presents why in the traditional model of education the concept of schooling is divided into two actions: teaching and educating. 'Educating' is limited to the moral sphere or gaining good manners.

By looking at New Zealand's system of education through the prism of the model presented above, we can understand what changes have occurred in the transformations that took place in 1989-1999. It was not yet the period of reforming the educational system on the basis of research approach, but the focus was rather put on administrative modifications. At that time education was perceived as a crucial factor of economic growth and social development. ${ }^{6}$ The report Ten years on: How schools view educational reform presents principals', trustees', parents', and teachers' opinions about the impact of the reforms. Some of the main findings seem to be rather negative: $87 \%$ of principals thought government funding was inadequate to meet school needs, rising workload and paperwork, longer working hours, more severe competition between schools, inequality in quality education. ${ }^{7}$

\section{An innovative evidence-based revision of education}

The weaknesses of the reform movement mentioned above became an incentive to modify thinking about education and the traditional model required a deeper reform. That became the starting point for developing a new approach known as evidence-based approach. At that point it is worth explaining the term 'evidence' and its source.

The meaning of the evidence-based approach can be explained by referring to Philip Davies, who indicates the relationship of this approach with the field of medicine (identifying and applying good practices). As an example, Davies presents University of Oxford Master's programme in Evidence-Based Health Care. He believes its central feature is that students learn by attempting to solve clinical and population-based problems that they bring to the course. This approach to learning, and teaching, is explicitly based on the problem-solving, self-directed model of adult education. ${ }^{8}$ It means that in order to treat a patient, medical practitioners need to take into ac-

${ }^{5}$ D. Benner, John Dewey, a Modern Thinker: On Education (as Bildung and Erziehung) and Democracy (as a Political System and a Mode of Associated Living), [in:] L. Waks, A. English (eds.), John Dewey's Democracy and Education: A Centennial Handbook, Cambridge University Press, Cambridge 2017, p. 265.

${ }^{6}$ G. Hawke, Education Reform: the New Zealand experience, pp. 3-4, https://www.researchgate. net/publication/228585086 Education reform the New Zealand experience.

${ }^{7}$ C. Wylie, Ten years on: How schools view educational reform, https://www.nzcer.org.nz/research/publications/ten-years-how-schools-view-educational-reform.

${ }^{8}$ P. Davies, What is Evidence-Based Education, "British Journal of Educational Studies" 1999, vol. 47 , no. 2, p. 110. 
count all the best available evidence but also use multiple forms and sources of those evidence. Alongside using the evidence from academic enquiries doctors collect and use data such as patient's histories or they set additional control tests.

It is then no surprise that the approach has inspired some academics to transfer good practice from medicine into education. Among many researchers who were trying to make use of the data was John Hattie who presented his findings in the form of Visible Learning concept.

Hattie presented his concept of Visible Learning in a book of the same name. ${ }^{9}$ These are research synthesises results from 1500 meta-analyses of 90,000 studies involving 300 million students into what works best in education presents multiple attributes that affect student learning. Deeper analyses of those influences on student achievement show the importance of both the student and the teacher in achieving objectives.

To determine the impact of teaching and learning activities on the achieved effect, Hattie developed a measure - the size of the effect. It is the difference between the average of the effects of the same group studied before and after the intervention or the difference between the average of the effects in the test group and the control group (without the intervention tested) divided by the standard deviation or the measure of dispersion (the measure of random changes). It is a number which has both positive and negative values. Hattie distinguished its 4 ranges: below 0.0 (negative) Decrease achievement; from 0.0 to 0.15 (low) What students could achieve without schooling; from 0.15 to 0.4 (medium) Typical effects of teachers on students that can be accomplished in a year of teaching; from 0.4 and above (high) Zone of desired effects. To illustrate the concept I will present one activity dependent on a teacher and a student from each area e.g. Negative effect: Retention $(-0.16)$ Television $(-0.18)$; Low effect: Reacher subject matter knowledge (0.09) Diet (0.12); Medium effect: Homework (0.29) Personality (0.19); High effect: Teacher clarity (0.75) Self-report grades (1.44). ${ }^{10}$

The proposed concept has met two types of criticism. On the one hand, the criticism affected the research methodology - calculating the size of the effect 'Fundamentally, Hattie's method is not statistically sophisticated and can be summarized as calculating averages and standard deviations, the latter of which he does not really use.' ${ }^{11}$ On the other hand, the Visible Learning theory itself has become the subject of criticism e.g.' it belongs to the radical constructivist paradigm therefore the problems of constructivism is directly connected with Hattie's concept of teaching, which results in a double breakdown of the essence of teaching. ${ }^{12}$ Despite criticism of Hattie's Vis-

\footnotetext{
${ }^{9}$ J. Hattie, Visible Learning, Routledge, New York 2008.

${ }_{10}$ Ibidem.

${ }^{11}$ P. J. Bergeron, How to engage in pseudoscience with real data: a criticism of John Hattie's arguments in Visible Learning from the perspective of a statistician, https://mje.mcgill.ca/article/ view/9475/7229.

12 T. A. Rømer, A Critique of John Hattie's Theory of Visible Learning, "Educational Philosophy and Theory" 2019, vol. 51, no. 6, pp. 587-598.
} 
ible Learning theory, the quest for justification of improving the school system, in particular teaching and learning, remains a current task. The change that has been made thanks to evidence-based approach should be continued in order to find better solutions between teaching and learning, which I suppose is the heart of the matter.

\section{A new perspective on education}

I believe that despite criticism Hattie's Visible Learning theory places his approach appropriately in the modified model of thinking about the relationship between teaching and learning and harmonizes with Benner's and Stępkowski's understanding of education. The synchronization of a student's and a teacher's interactions create real education. Both participants of pedagogical action are needed and have separate activities to perform - one teaching, the other one learning. The introduction of harmony or synergy in these activities is the task of school education. It is also the key to success in education.

This concept where both activities equally contribute to education is well depicted by Dietrich Benner in the form of a modified didactic triangle. ${ }^{13}$ The following figure presented in Figure 2 is a graphical representation of Benner's proposal.

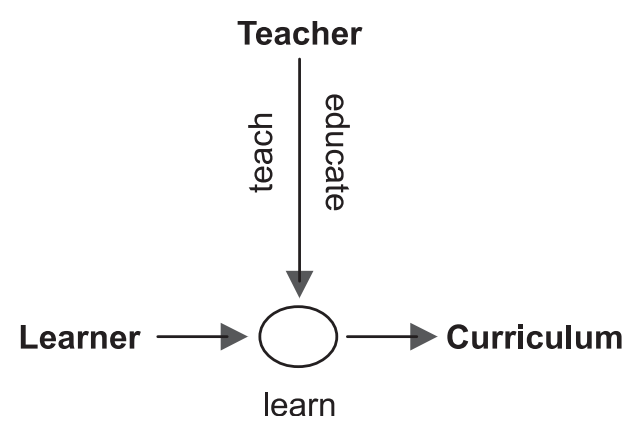

Figure 2. Modified didactic triangle

Source: D. Benner, Allgemeine Pädagogik und Sonderpädagogik. Überlegungen zum Verhältnis von Inklusion und Exklusion aus der Sicht Dreier Kausalitäten in Erziehungs- und Bildungsprozessen, "Człowiek - Niepełnosprawność Społeczeństwo" 2018, vol. 4(42), p. 9.

Although the position of participants of the didactic situation - the 'Teacher' and the 'Learner' - is the same as expressed in Figure 1, the arrangement of the activities performed by them in relation to 'Curriculum' is fundamentally different. It is worth remembering here that in the traditional system of education the 'Curriculum' is the object of an exchange between the 'Teacher' and the 'Learner'. In the new concept of

13 D. Benner, Allgemeine Pädagogik und Sonderpädagogik. Überlegungen zum Verhältnis von Inklusion und Exklusion aus der Sicht Dreiser Kausalitäten in Erziehungs- und Bildungsprozessen, “Człowiek - Niepełnosprawność - Społeczeństwo” 2018, vol. 4(42). 
education (the same as in evidence-based education), however, it is the goal of performing the activities of 'learn/teach'. The activities 'teach/educate' coming from the 'Teacher' side are aimed at the area marked with the circle in which they meet the 'Student's' activities.

The above considerations on teaching and learning may support my reconstruction of the way school education and its system have changed in Australia and New Zealand. To confirm that view, I would like to draw one's attention to a bottom-up movement that has been triggered by the search for a better teaching/learning model. In this context, the undoubted merit of Hatti's Visible Learning theory is the encouragement to reflect and to change school practice - it is sort of the third face of Visible Learning. In this part, a bottom-up change in the way of thinking about the relationship between teaching and learning that is taking place, regardless of Hatti's theory and book, can be illustrated by the results that both New Zealand and Australia achieve in the PISA study.

In 2001 the Organization for Economic Cooperation and Development (OECD) published the first Programme for International Student Achievement (PISA) results of 15 -year-olds' achievement in reading literacy in OECD countries. The test was conducted among 265 thousand students from 32 countries. The countries which received results at 'High quality and Low equity' level were: Finland, Canada, Ireland, Korea, Japan, Sweden, Austria and Iceland. The countries which received results at 'High quality and High equity' level were: New Zealand, Australia, Belgium, Norway, United Kingdom, United States. The countries which received results at 'Low quality and High equity' level were: Czech Republic, Spain, Hungary, Mexico. The countries which received results at 'Low quality and Low equity' level were: Poland, Greece, Portugal, Luxembourg, Denmark, Switzerland, Germany.

It is clear that PISA is being criticised for e.g.

underestimating the margin of error on the scores provided by the OECD, ranking of countries from best to worst what is more open to interpretation than one would understand from OECD analyses. To resolve this issue, the OECD should provide PISA users with a structured sensitivity analysis that takes all the variables in the ranking into account. ${ }^{14}$

The interesting fact in the view of the above model of the relationship between teaching and learning is that both New Zealand and Australia had high achievements, but achievement disparities were quite wide (High Average and Large Variance). This means that despite the reform movement in the education system of both countries, prevailed thinking that according to a traditional education model the external factors not relationship between a teacher and a student is in the center of attention.

14 A. Saltelli, The International PISA tests show how evidence-based policy can go wrong, https://theconversation.com/international-pisa-tests-show-how-evidence-based-policy-can-gowrong-77847. 
When looking for the reasons of this situation, it is worth to pay attention to the report from 2004 Using Best Evidence Syntheses to Assist in Making a Bigger Difference for Diverse Learners prepared by New Zealand's Ministry of Education explains that

for New Zealand, such variance is predominantly within-school variance rather than between-school variance, suggesting an important role for New Zealand principals in both recognizing excellence within their schools, and building up the quality of teaching across the school. ${ }^{15}$

As it turns out from the quote, the reasons of the above differences in the quality of education were noticed both in the work of a teacher and school. In other words the same schools educate students who gain really high scores in external tests and students who receive poor results. Therefore, neither the government nor the system of education but individual schools and teachers seem to have the biggest impact and are responsible for effective education. ${ }^{16}$

The focus both in Australia and New Zealand has shifted in recent years from pointing at influences of the home, the structures of schools, investing money into school buildings, greater use of modern technologies and creating new examinations. ${ }^{17}$ The above valid considerations lead to seeking better ways of teachers' and schools' functioning and sharing their experiences. Examples of activities in this area will be presented below.

The vital areas which are nowadays undergoing constant improvements include, among others: implementing a variety of research-based strategies and approaches to improve learning ${ }^{18}$, effective collaboration within and between schools ${ }^{19}$, developing students' features of leadership and moral courage ${ }^{20}$, developing students' features of confidence and creativity ${ }^{21}$, review and improvement of curriculum. ${ }^{22}$ The interventions in those areas are student centred, tailored exactly to specific school requirements and all concern two main participants of education process: a learner and a teacher.

${ }^{15}$ A. Alton-Lee, Using Best Evidence Syntheses to Assist in Making a Bigger Difference for Diverse Learners, p. 3, http://www.leadspace.govt.nz/leadership/leading learning/synthesis.php.

${ }^{16}$ Ibidem.

17 J. Hattie, Distinguishing Expert Teachers from Novice and Experienced Teachers, p. 2, https:// research.acer.edu.au/cgi/viewcontent.cgi? article $=1003 \&$ context=research conference 2003.

${ }_{18}$ Keeping children engaged and achieving in reading, https://www.ero.govt.nz/assets/Uploads/ ERO-AoG-17985-Teaching-strategies-that-work-Reading-v3.pdf.

${ }_{19}$ Collaboration to improve learner outcomes. What does the evidence tell us about what works, https://www.ero.govt.nz/assets/Uploads/Collaboration-to-Improve-Learner-Outcomes.pdf.

${ }^{20}$ What Drives Learning in the Senior Secondary School?, https://www.ero.govt.nz/publications/ what-drives-learning-in-the-senior-secondary-school/.

${ }^{21}$ Melbourne Declaration on Educational Goals for Young Australians, http://www.curriculum. edu.au/verve/ resources/National Declaration on the Educational Goals for Young Australians.pdf.

22 "Primary Matters" 2015, Issue 5, http://docs.acara.edu.au/resources/20150420 Primary Matters Issue 5 2015.pdf. 
In order to develop an efficient evidence-based educational strategy, decision or improvement Australian and New Zealand school leaders and teachers first gather, analyse, and use objective data. They primarily focus on research and 'quantitative' numerical data but also the use a of 'qualitative' information is quite vital. With the purpose of collecting and managing only high quality student related data educators are provided with professional help and guidelines. In Australia teachers are provided with procedures by e.g. NSW Government Department of Education. ${ }^{23}$ Moreover, in order to keep quality teaching they regularly undergo professional training. Data Driven Evidence Based Teaching in Schools is a conference to benefit the needs of teachers in Australia. ${ }^{24}$

The appropriate Evidence-Based Teaching model exploration in New Zealand aims at changing the viewpoint of what education is. The government reports and findings presented above convince me that the learner and his active role is more and more emphasised in education process. Furthermore, the Ministry of Education and subordinate institutions make successful use of evidence and devolve this notion downwards. The concept of Visible Learning is deeply rooted in a classroom practice and is supported by the system.

\section{New Zealand and Australia - the use of Visible Learning in effective student education}

The above Figure 2 explains the position and actions of two participants of educational situation. The new area which lies between the Learner, Teacher and the Curriculum is constituted from blending the actions - teach/educate and learn. Both participants of the pedagogical interaction perform actions assigned to their role (teachers do not absolve young people of being active, do not hurry, give time to think, allow learners to perform actions on their own, allow them to make mistakes, etc.).

Teachers who cooperate with their students in this way start to understand them better and get to know their aspirations and dreams. New Zealand's Ministry of Education endorses the above opinion: 'sharing power and the responsibility for learning, teachers set their students on a path to fulfilling the vision we have for them, with the ability to secure a sustainable social, cultural, economic and environmental future for our country'. ${ }^{25}$

${ }^{23}$ Principles for collecting internal school data, https://education.nsw.gov.au/teaching-and-learning/school-excellence-and-accountability/sef-evidence-guide/guidelines-for-using-data/collecting-internal-school-data.

${ }^{24}$ Data Driven Evidence Based Teaching in Schools conference, https://www.criterionconferences.com/event/evidence-based-teaching-conference/brochure/.

${ }^{25}$ Leading Innovative Learning in New Zealand Schools, p. 11, https://www.ero.govt.nz/assets/ Uploads/Leading-Innovative-Learning-in-Schools-2018.pdf. 
The Leading Innovative Learning in New Zealand Schools report illustrates the actions undertaken by all the examined school teachers. They were constantly looking for new solutions to improve the results of their students and to make learning relevant for the future: 'they were striving to develop students who were both academically successful, in relation to New Zealand education standards and qualifications, as well as confident, connected and actively involved learners. ${ }^{26}$

High quality data are used predominantly for the main components of education:

1. Teacher - being a great teacher has long been perceived as an inborn ability. Quality teaching has been examined by Eric Hanushek, an economist at Stanford University. He has established that during a school year 'pupils taught by teachers at the 90th percentile for effectiveness learn 1.5 years' worth of material. Those taught by teachers at the 10th percentile learn half a year's worth. ${ }^{27}$

Hattie goes deeper as far as an expert teacher is concerned and provides a list of 16 prototypic attributes of a great teacher. According to Hattie expert teachers adopt a problem-solving stance to their work, are proficient at creating an optimal classroom climate for learning. Expert teachers have a multidimensionally complex perception of classroom situations, are more adept at monitoring student problems and assessing their level of understanding and progress, and they provide much more relevant, useful feedback. Those teachers have high respect for students, are passionate about teaching and learning. They engage students in learning and help to develop their students' self-regulation, learning skills, self-efficacy, and self-esteem. ${ }^{28}$

In order to facilitate quality teaching the Australian Department of Education and Training has developed the High Impact Teaching Strategies (HITS). These are 10 instructional practices that emerge from the findings of international researchers like John Hattie and Robert Marzano. The strategies give 'teachers and school leaders an opportunity to embed and share the use of successful instructional practices. ${ }^{29}$

Another helpful tool which enables teachers to share their practice-based evidence is at the Australian researchED (Australian College of Educators, 2017), which started at the Australian Council for Educational Research (ACER) Excellence in Professional Practice Conference (ACER, 2017). ${ }^{30}$ This platform allows practitioners to publish their findings, share their way of thinking and helps 'great practice become common practice. ${ }^{31}$

\footnotetext{
${ }^{26}$ Ibidem, p. 16.

${ }_{27}$ Teaching the teachers., https://www.economist.com/briefing/2016/06/11/teaching-the-teachers.

${ }^{28}$ J. Hattie, Distinguishing Expert Teachers from Novice and Experienced Teacher, https://research.acer.edu.au/cgi/viewcontent.cgi? article=1003\&context=research conference 2003.

${ }^{29}$ High Impact Teaching Strategies. Excellence in Teaching and Learning, p. 7, https://www.education.vic.gov.au/school/teachers/teachingresources/practice/improve/Pages/hits.aspx.

${ }^{30}$ Australian Council for Educational Research, https://www.acer.org/au.

${ }^{31}$ M. Deeble, T. Vaughan, An evidence broker for Australian schools, Centre for Strategic Education, Victoria 2018, p. 13.
} 
New Zealand's Education Review Office (ERO) helps teachers cooperate with parents and the local community by informing and explaining the complexity of the education process.

To help every student make progress, teachers have to find out what each student knows and can do. Teachers want to build on the strengths of each of their students. This involves teachers constantly reviewing their teaching practice is it working, and what changes are needed?. ${ }^{32}$

Moreover, the Office clarifies the nature of best teachers: Effective teachers are flexible and responsive to all their students, use different teaching approaches for students who need extra support or extensions, draw on the support and expertise of other adults to help with some of their students, and also use the expertise of community members. ${ }^{33}$

2. Learner - it is worth remembering that according to Hattie on about $50 \%$ of the variance of student's achievement is due to the student him/herself. This refers mainly to the student's prior knowledge and abilities. Recent improvements in the Australian education system have been led by David Gonski who was assigned his job in 2010 by the Minister of Education. Later, the proposed reforms and funding model became known as "Gonski". The second Gonski report, referred to as Gonski 2.0, was published on 30 April 2018. Gonski is aware that 'learning is unlikely when people are taught what they already know or when they lack the prerequisite knowledge or skills for success. ${ }^{34}$ Gonski's model looks at successful learning from a totally different angle 'rather than being judged only in terms of age-based expectations, successful learning would be measured as the progress individuals make, whatever their starting points. ${ }^{35}$

3. Curriculum - the shape of the present Australian Curriculum was approved by the Australian Curriculum Assessment and Reporting Authority (ACARA) Board in 2012. The Curriculum undergoes systematic evaluation by ACARA. ${ }^{36}$ This government institution is collecting feedback and analysing data on curriculum's effectiveness by reporting these findings to the government and public every year. ${ }^{37}$ The ACARA Board determines if any newest findings require further evaluation and change in the curriculum. For instance, in 2014 as a result of the review of the Australian

${ }^{32}$ Effective Teaching What's happening in my child's classroom?, p. 2, https://www.ero.govt.nz/ assets/Uploads/Effective-Teaching.pdf.

${ }^{33}$ Ibidem, p. 5.

${ }^{34}$ G. Masters, Gonski, learning and the case for change, https://www.teachermagazine.com.au/ columnists/geoff-masters/gonski-learning-and-the-case-for-change.

${ }^{35}$ G. Masters, Gonski's model for schools, https://www.teachermagazine.com.au/columnists/ geoff-masters/gonskis-model-for-schools.

36 "Primary Matters" 2014, Issue 2, http://docs.acara.edu.au/resources/20140710 Primary Matters issue 2.pdf.

${ }^{37}$ Monitoring the effectiveness of the Foundation - Year 10 Australian Curriculum Annual Report, https://www.acara.edu.au/docs/default-source/curriculum/20180122 2017-monitoring-report.pdf. 
Curriculum the federal government recognised a problem of overcrowded curriculum. Later on vital steps were taken leading to curriculum improvement (March 2015 meetings of education ministers, 12-13 March 2015 cooperation of practising primary teachers from around the country with ACARA officers to provide input and feedback on options for reducing, redesigning and rebalancing the curriculum for primary schools).$^{38}$ The Australian Curriculum consists of the three dimensions learning areas, general capabilities and cross-curriculum priorities. Each school has the right to create its own unique way of using the dimensions as they implement the Australian Curriculum.

In 2010, around the same time as in Australia, schools in New Zealand were obliged to implement The New Zealand Curriculum. ${ }^{39}$ There are eight principles of The New Zealand Curriculum. The principles are for example: High expectations, Learning to learn, Future focus. ${ }^{40}$ The Ministry of Education assigned ERO to regularly evaluate the extent to which the principles of The New Zealand Curriculum are present in schools' curricula and applied in classrooms. ${ }^{41}$ Similarly to Australia, The New Zealand Curriculum permits all schools to

'design their own learning programmes to meet the needs of their communities and students. Every school's curriculum should be a unique and responsive blueprint of what they and their community consider is important and desirable for students to learn. The vision, values, principles and key competencies of The New Zealand Curriculum provide a framework for stakeholders to engage in discussion about the kind of people they want students to be, and the best means to support students to develop their potential ${ }^{42}$.

Both Australian and New Zealand schools practice curriculum connection. It is considered to be 'effective in stimulating effective collaboration between teachers and students at many levels. It is distinctive from a thematic approach in that it consciously maintains the rigour of each of the learning areas. It clearly empowers the learning through connections and does not lose the integrity of the individual subject. ${ }^{4}$ Philip Jellyman, the headteacher at St Dominic's Catholic College in New Zealand, has investigated twelve schools to look for the ways in which curriculum integration has been implemented. He believes that combined curriculum 'has the potential to

38 “Primary Matters" 2015, Issue 5, http://docs.acara.edu.au/resources/20150420 Primary Matters Issue 5 2015.pdf.

39 The New Zealand Curriculum Principles: Foundations for Curriculum Decision-Making, https://www.ero.govt.nz/assets/Uploads/Curriculum-Principles-2012.pdf.

${ }^{40}$ Annual Report 2017/18, p. 3, https://www.ero.govt.nz/assets/Uploads/ERO-Annual-Report-2018.pdf.

${ }^{41}$ Ibidem.

${ }^{42}$ Ibidem.

43 "Primary Matters" 2017, Issue 11, https://www.acara.edu.au/curriculum/primary-matters-newsletter/primary-matters-may-2017. 
enhance student learning and competencies beyond what is generally possible in subject specific lessons'. ${ }^{44}$

\section{Conclusions}

New Zealand's and Australia's education systems have reformed education not by implementing structural changes in the system itself, but by putting an emphasis on a new and innovative perception of what education and education improvement is. A vital element in this process was development of research on Evidence Based Teaching and in particular the concept of Hatti's Visible Learning. Visible Learning is the key to understanding the changes that are taking place. It does not mean, however, that this concept is uncritically supported ${ }^{45}$, but undoubtedly it makes the pedagogical interaction not only visible but also effective And this is the direction that New Zealand's and Australia's educational systems are heading - to encourage teachers to see what they can do and how it works for the students. In a longer perspective it encourages teachers to modify their own activities.

I believe the improvements and changes in Polish educational system should and can be based on evidence. Scientists and practitioners should establish closer cooperation in order to find and analyse quantitative and qualitative data. The shape and direction of the changes in the Polish system of education need to be made on the basis of high quality evidence. But foremost there needs to be a different way of looking at the two participants of the education process: the learner and the teacher. The learner should be encouraged by schools to a become a more proactive participant. The teacher's role should be to 'bring up' all the student's assets.

That may be the key to quality teaching.

\section{Bibliography}

Alton-Lee A., Using Best Evidence Syntheses to Assist in Making a Bigger Difference for Diverse Learners, http://www.leadspace.govt.nz/leadership/leading learning/ synthesis.php [access: 14.06.2019].

Annual Report 2017/18, https://www.ero.govt.nz/assets/Uploads/ERO-Annual-Report-2018.pdf [access: 14.06.2019].

${ }^{44}$ P. Jellyman, Models of Curriculum Integration in New Zealand Secondary Schools, Sabbatical report, Term 2, 2015, St Dominic's Catholic College, p. 7, http://www.educationalleaders.govt.nz/ Leadership-development/SSMs-sabbatical-reports/SSM-award-recipients-2015/Jellyman-Philip.

${ }^{45}$ I. Snook, J. Clark, R. Harker, A.-M. O’Neill, J. O’Neill, Critic and conscience of society: A reply to John Hattie, 'New Zealand Journal of Educational Studies' 2010, vol. 45(2), p. 93. 
Australian Council for Educational Research, https://www.acer.org/au [access: 14.06.2019].

Benner D., Allgemeine Pädagogik und Sonderpädagogik. Überlegungen zum Verhältnis von Inklusion und Exklusion aus der Sicht Dreiser Kausalitäten in Erziehungsund Bildungsprozessen, "Człowiek - Niepełnosprawność - Społeczeństwo" 2018, vol. 4(42).

Benner D., John Dewey, a Modern Thinker: On Education (as Bildung and Erziehung) and Democracy (as a Political System and a Mode of Associated Living), [in:] L. Waks, A. English (eds.), John Dewey's Democracy and Education: A Centennial Handbook, Cambridge University Press, Cambridge 2017.

Bergeron P.J., How to engage in pseudoscience with real data : a criticism of John Hattie's arguments in Visible Learning from the perspective of a statistician, https://mje. mcgill.ca/article/view/9475/7229 [access: 10.12.2019].

Collaboration to improve learner outcomes. What does the evidence tell us about what works, https://www.ero.govt.nz/assets/Uploads/Collaboration-to-Improve-Learner-Outcomes.pdf [access: 14.06.2019].

Data Driven Evidence Based Teaching in Schools conference, https://www.criterionconferences.com/event/evidence-based-teaching-conference/brochure/ [access: 14.06.2019].

Davies P., What is Evidence-Based Education, "British Journal of Educational Studies" 1999, vol. 47, no. 2 .

Deeble M., Vaughan T., An evidence broker for Australian schools, Centre for Strategic Education, Victoria 2018.

Earl L., Kat S., Leading Schools in a Data-Rich World, https://www.researchgate.net/ publication/252669674 Leading Schools in a Data-Rich World [access: 14.06.2019].

Effective Teaching What's happening in my child's classroom?, https://www.ero.govt.nz/ assets/Uploads/Effective-Teaching.pdf [access: 14.06.2019].

Hattie J., Distinguishing Expert Teachers from Novice and Experienced Teachers, https://research.acer.edu.au/cgi/viewcontent.cgi?article $=1003 \&$ context $=$ research conference 2003 [access: 14.06.2019].

Hattie J., Visible Learning, New York 2008.

Hawke G., Education Reform: the New Zealand experience, https://www.researchgate. net/publication/228585086 Education reform the New Zealand experience [access: 14.06.2019].

High Impact Teaching Strategies. Excellence in Teaching and Learning, https://www. education.vic.gov.au/school/teachers/teachingresources/practice/improve/ Pages/hits.aspx [access: 14.06.2019].

Jellyman P., Models of Curriculum Integration in New Zealand Secondary Schools, Sabbatical report, Term 2, 2015, St Dominic's Catholic College, http://www.ed- 
ucationalleaders.govt.nz/Leadership-development/SSMs-sabbatical-reports/ SSM-award-recipients-2015/Jellyman-Philip [access: 14.06.2019].

Keeping children engaged and achieving in reading, https://www.ero.govt.nz/assets/ Uploads/ERO-AoG-17985-Teaching-strategies-that-work-Reading-v3.pdf [access: 14.06.2019].

Klus-Stańska D., Dlaczego szkolna kultura dydaktyczna się nie zmienia, "Studia Pedagogiczne" 2011, t. LXIV.

Leading Innovative Learning in New Zealand Schools, https://www.ero.govt.nz/assets/Uploads/Leading-Innovative-Learning-in-Schools-2018.pdf [access: 14.06.2019].

Masters G., Gonski, learning and the case for change, https://www.teachermagazine. com.au/columnists/geoff-masters/gonski-learning-and-the-case-for-change [access: 14.06.2019].

Masters G., Gonski's model for schools, https://www.teachermagazine.com.au/columnists/geoff-masters/gonskis-model-for schools [access: 14.06.2019].

Masters G., The Role of Evidence in Teaching and Learning, https://www.teachermagazine.com.au/columnists/geoff-masters/the-role-of-evidence-in-teachingand-learning [access: 14.06.2019].

Melbourne Declaration on Educational Goals for Young Australians, http://www.curriculum.edu.au/verve/ resources/National Declaration on the Educational Goals for_Young_Australians.pdf [access: 14.06.2019].

Monitoring the effectiveness of the Foundation - Year 10 Australian Curriculum Annual Report, https://www.acara.edu.au/docs/default-source/curriculum/20180122 2017-monitoring-report.pdf [access: 14.06.2019].

“Primary Matters" 2014, Issue 2, http://docs.acara.edu.au/resources/20140710 Primary Matters issue 2.pdf [access: 14.06.2019].

"Primary Matters" 2015, Issue 5, http://docs.acara.edu.au/resources/20150420 Primary Matters Issue 5 2015.pdf [access: 14.06.2019].

"Primary Matters" 2017, Issue 11, https://www.acara.edu.au/curriculum/primary-matters-newsletter/primary-matters-may-2017 [access: 14.06.2019].

Principles for collecting internal school data, https://education.nsw.gov.au/teaching-and-learning/school-excellence-and-accountability/sef-evidence-guide/ guidelines-for-using-data/collecting-internal-school-data [access: 14.06.2019].

Rømer T. A., A Critique of John Hattie's Theory of Visible Learning, "Educational Philosophy and Theory" 2019, vol. 51, no. 6, pp. 587-598.

Saltelli A., The International PISA tests show how evidence-based policy can go wrong, “The Conversation" 2017, https://theconversation.com/international-pisa-tests-show-how-evidence-based-policy-can-go-wrong-77847 [access: 10.12.2019]. 
Stępkowski D., Kształcenie jako dobro pedagogiczne i źródło nierówności edukacyjnej, (in print).

Snook I., Clark J., Harker R., O'Neill A.-M., O'Neill J., Critic and conscience of society: A reply to John Hattie, "New Zealand Journal of Educational Studies" 2010, vol. 45(2).

Teaching the teachers, https://www.economist.com/briefing/2016/06/11/teaching-the-teachers [access: 14.06.2019].

The New Zealand Curriculum Principles: Foundations for Curriculum Decision-Making, https://www.ero.govt.nz/assets/Uploads/Curriculum-Principles-2012.pdf [access: 14.06.2019].

What Drives Learning in the Senior Secondary School?, https://www.ero.govt.nz/ publications/what-drives-learning-in-the-senior-secondary school// [access: 14.06.2019].

Wylie C., Ten years on: How schools view educational reform, https://www.nzcer.org. nz/research/publications/ten-years-how-schools-view-educational-reform [access: 14.06.2019]. 


\title{
Dace Siliņa*
}

University of Latvia

\author{
Kamila Witerska** (iD) https://orcid.org/0000-0003-2451-0016 \\ University of Humanities and Economics in Lodz, Poland
}

https://doi.org/10.25312/2083-2923.16/2019_11dskw

\section{How to make a step towards future education. Teaching/learning methods in higher education for the $\mathbf{2 1}$ st century}

\begin{abstract}
The rapid development of the world requires new improvements in every field of life, and demands new knowledge and skills from each worker. The employers expects a workforce with a new set of skills. Higher education institutions need to change and reshape their current offer and provide a learning process through which people acquire the skills required by employers. In order to ensure such a learning process is successful, it is important to explore the vision of both sides - students and lecturers - and to offer a new, up-to-date innovative training process. It is important to offer up-to-date tools - methods to work within the learning process.

Students expect the training process to be motivating and engaging. Students demand that the learning process will successfully prepare them for the labour market. Lecturers focus on identifying new requirements and ways/methods to change their training process to ensure students' demands are met.
\end{abstract}

* Dace Siliņa studied psychology and sociology at the University of Latvia. Dace has worked in social, market and media research field as project manager and fieldwork manager, and has created and developed a training system and managed it. Since 2009 Dace has worked as a coach and career counsellor, and offers seminars.

* Kamila Witerska PhD - lecturer at the Faculty of Pedagogy at the University of Humanities and Economics in Lodz. She was awarded a doctorate in pedagogy from the Faculty of Pedagogy at the University of Warsaw. She is interested in drama, stimulating motivation and creative thinking, and supporting development. She is the author of publications on drama used in different age groups: Drama at various levels of education (2010) and a practical guide to drama techniques: Drama. Techniques, Strategies, Scenarios (2011). The latest publication concerns the Forum Theatre (2016), a new method used in peer education, prevention and sociotherapy. 
In this article, we reflect on the research carried out under the "Entrance to future education" project (efe-project.eu). The aim of the project was to identify and compile training methods that meet the requirements of the 21 st century. As part of the project, we studied how students and trainers assess workshops and lectures in which at least one of the favoured methods was used. The article also reflects on the assessment of training programmes for trainers regarding the learning of new teaching methods.

Keywords: learning methods, learning outcome, creativity, motivation, engagement, training

\section{Introduction}

The Entrance to Future Education (EFE) project is a two year project involving universities and organisations in Latvia, Poland and Belgium, supported by the European Commission's Erasmus+ programme. The main aim of the project is to develop and promote innovative methods and approaches to teaching in higher education.

The Entrance to Future Education project identifies the demands and needs of both sides - students and teachers - in order to achieve a successful learning outcome, as well as providing methods and training programmes to aid teachers. The final materials prepared within the project have been tested to assess their effectiveness to achieve the current targets set in the training process.

\section{$21^{\text {st }}$ century education}

We are two decades into the 21 st century. The previous century was one of very rapid changes in technology, biology, medicine and the social sphere. Changes this century occur even more rapidly. Ken Robinson states that we live in a world that is changing faster than in the past, is unpredictable, and this is why creative skills need developing. ${ }^{1}$ In the face of these changes, the model of education which positions the teacher as transmitting knowledge and the student as a receiver is unsustainable.

Because of the development of IT technology students nowadays have many sources of knowledge and permanent access to them. Mobile applications provide new ways of engaging with information. They are attractive to some students and intuitive, therefore easy to use.

That is why nowadays transforming knowledge in a creative way is going to be the key activity of the learning process and also a required feature of employees. Academic teaching is going to be replaced by the creative project, design thinking or flipped classroom. ${ }^{2}$

\footnotetext{
${ }^{1}$ K. Robinson, Out of Our Minds: Learning to be creative, Capstone Publishing Ltd., Oxford 2011.

2 Description of approaches and methods on the EFE project website: http://efe-project.eu/ methods.
} 
One approach is the creative project. The project method used to be a basic method of progressivism. Although its sources can be traced back to the 16th century in European Academies training architects, the development of the method occurred at the turn of the 19th and 20th centuries in the United States. The concept of the project was known to a leading American progressive, John Dewey, for whom it was associated with solving practical problems. ${ }^{3}$

The project method was defined by another progressive, Dewey's student, William Kilpatrick. According to him, we always deal with a project whenever a student takes some action for a specific purpose. Therefore, positive motivation was to be the decisive criterion for the project. Kilpatrick distinguished 4 project phases:

1) purpose

2) plan

3) conduct

4) evaluation. ${ }^{4}$

Today, the project method is defined as a method whereby a team of students initiates, plans and implements a certain undertaking on their own and assesses its implementation. When we talk about a creative project it is important to achieve some extraordinary outcome.

One of the most valuable aspects of this approach is that it is based on real-life challenges or problems. Students are expected to think of creative solutions to problems. It is also important to find some subjective outcomes - what we have achieved by this project for other people and for ourselves (efe-project.eu/methods/creative-project).

Another approach addressed to a particular vision of 21 st century education is design-thinking. ${ }^{5}$ In this approach a group first decides on the problem/product to be solved/designed. The aim of the design thinking approach applied in higher education is to obtain a balance between academic knowledge and practical relevance. Students design a solution to the problem outlined at the beginning of the course. The implementation of the solution is supposed to work and improve the situation.

In this approach, students try to find creative solutions to a specific problem or challenge. The main outcome is a specific solution/project/product addressing those (users) affected by this problem or challenge and considerably improving the situation. (efe-project.eu/methods/design-thinking).

3 J. Dewey, How we think, Dover Pub inc, Mineola, New York 1997.

${ }^{4}$ M.S. Szymański, O metodzie projektów, Wydawnictwo Akademickie ŻAK, Warszawa, 2010.

${ }^{5}$ Por. np. T. Brown, Change by design, HarperBusiness, New York, 2009; N. Cross, Design Thinking, Berg Publishers, Oxford, New York, 2011; B. Michalska-Dominiak, P. Grocholiński, Poradnik design thinking, czyli jak wykorzystać myślenie projektowe w biznesie, Helion, Gliwice 2019. 
Another approach 'flips' the classroom. ${ }^{6}$ The flipped classroom idea means adapting what is done traditionally in the lecture - one way transmission of knowledge through lectures - and making the lecture content available to students to either watch or read in their own time and as preparation for the class. You then use face-to-face classroom time for active learning opportunities where the emphasis is on higher-order cognitive skills such as the skills of analysis, problem-solving and evaluation. Much of the supporting literature suggests that 'flipping' the classroom in this way supports deeper learning, is a better and more efficient use of increasingly dwindling resources and helps students achieve a far more comprehensive understanding of the subject matter. ${ }^{7}$

The new approaches need new methods. Those tested in EFE project were:

- Manifesto

- Role Play

- Brainstorming

- Simulation

- Interactive hunt

- Future Scenario Planning

- Petal Debate

- Storytelling

- Jigsaw

- Chalk Talk

- Draw Your Knowledge

- Speed Tutoring

- Colour, Symbol Image

- Circle of Viewpoints

- WebQuests

- Virtual Field Trip

- Ask an expert

- Word Webs

- Video catch-up

- Class wiki

- Virtual Exhibition

- Think-Aloud-Pair-Share

- Knowledge clips

- Documentary making

- Clustering

- What? So What? Now What?

- Tell and sell

${ }^{6}$ C. Reidsema, L. Kavanagh, R. Hadgraft, N. Smith, The Flipped Classroom. Practice and Practices in Higher Education, Springer, Singapore 2017.

${ }^{7}$ efe-project.eu/methods/flipped-classroom. 
- Genealogy of an idea

- 3-2-1 Processor

- Translate it!

- Leader as Coach. ${ }^{8}$

All the methods tested involve students' creativity and cooperation. Some of them have a strong visual component, some of them are connected with IT technology. All of the methods are to engage students into learning process.

\section{Assessment of the use of training methods}

As part of the project, there was a vocational training programme set for lecturers to present the methods gathered in the project and to provide fresh inspiration for the development of the study process. As a practical task within the programme, one of the proposed training methods was supposed to be selected and used in one of the lectures or seminars with students. The applied training programme and methods were tested by 29 lecturers from Latvia, 40 from Belgium and 17 from Poland. In total 21 methods were tested. The choice of methods was based on both the subject of the curriculum and the specific workshop or lecture.

Following the work carried out, both lecturers and students were asked during specific lectures/workshop to evaluate the lectures/workshop by completing a questionnaire. The aim of testing was to observe whether and how the methods collected in the project achieved the objectives, i.e. training methods should contribute to the motivation of students and their involvement in the learning process.

In general, 680 students from Latvia, Belgium and Poland participated in the survey.

At first, students were asked to assess the statement "The lesson/seminar was motivational." $95 \%$ of students indicated their agreement with this statement (see: Figure 1). $97 \%$ of students agreed with the statement that "The lecture/seminar was engaging and interesting" (see: Figure 2).

\footnotetext{
${ }^{8}$ http://efe-project.eu/methods.
} 


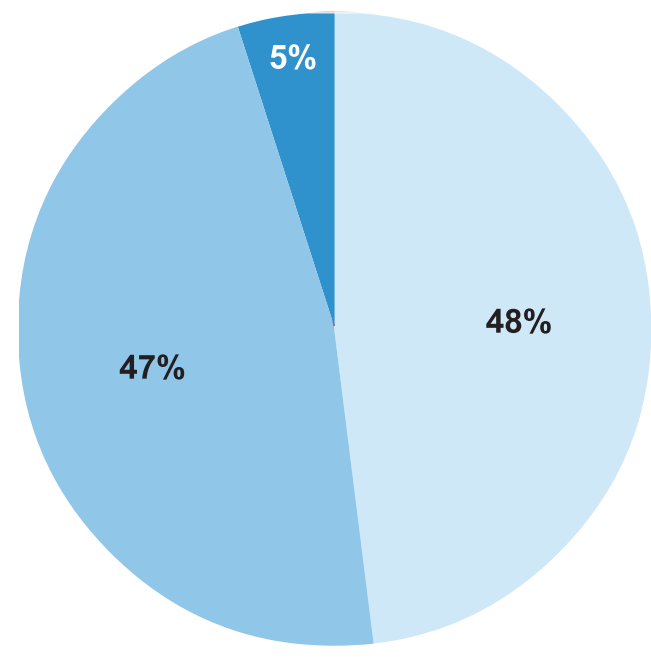

Figure 1

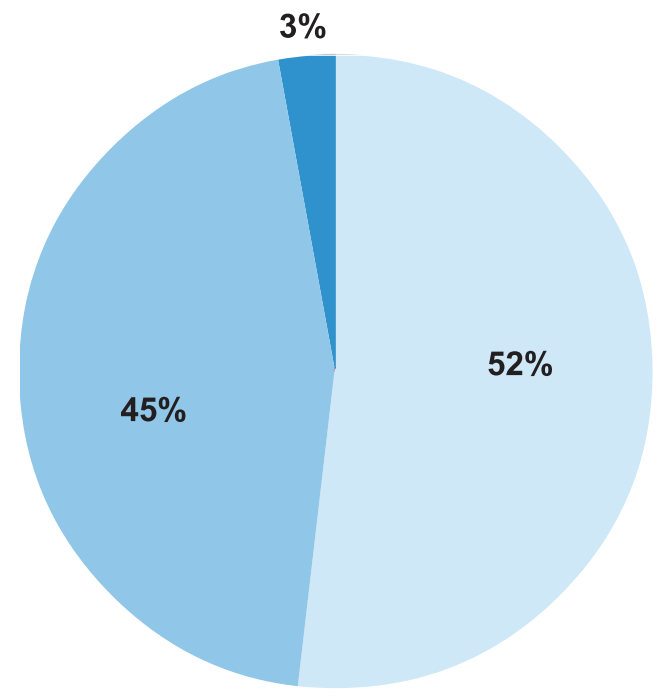

Figure 2
Fully agree

Partly agree

Partly disagree

\section{Fully agree \\ Partly agree \\ Partly disagree}

The result allows us to conclude that, in general, the training methods used by our lecturers achieved the objective pursued by the project team: creating a motivational and inclusive learning environment in the process of acquiring the necessary skills.

A clear understanding of the students' tasks during lectures/seminars is an essential element in motivation and engagement. The methods collected include both relatively simpler tasks and more sophisticated job settings. It also differs if a task requires a student to prepare outside the lecture time. $92 \%$ of the students surveyed indicated that it was easy to see what was expected of them during the lesson - "I understood clearly what was expected from me during this lesson" (see: Figure 3). More than half 
of the respondents fully agree with this statement, while 39\% partly agree with the statement. This suggests that sometimes students have to make an effort to understand the task, or sometimes (based on student comments) the meaning of the task becomes clearer during the performance of the task. It should be noted that in this process the ability of the teacher to explain the task accurately and comprehensively is also very important. In general, student judgement allows us to think that both the methods used, and the explanations provided by the teaching staff make it easy to understand the tasks that have been set during the lesson.
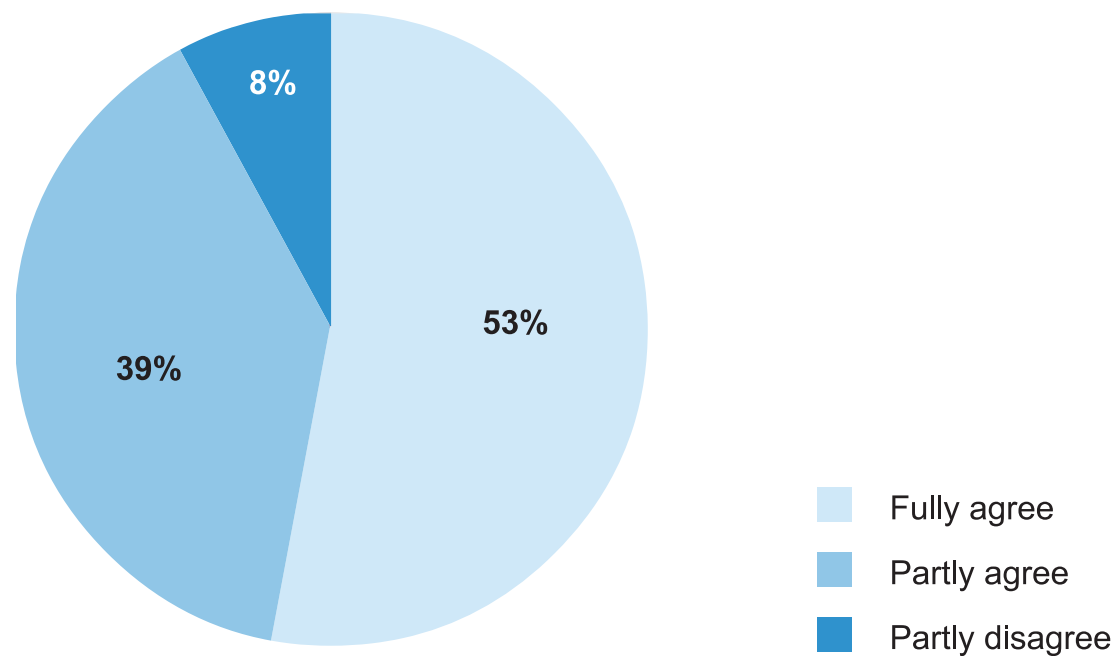

Figure 3

Slightly different from previous data are the students' assessments of the statement "All students participated fully during this lesson" (see: Figure 4). 1/4 share does not agree with this statement, while some $1 / 3$ of the students surveyed partly agree. 


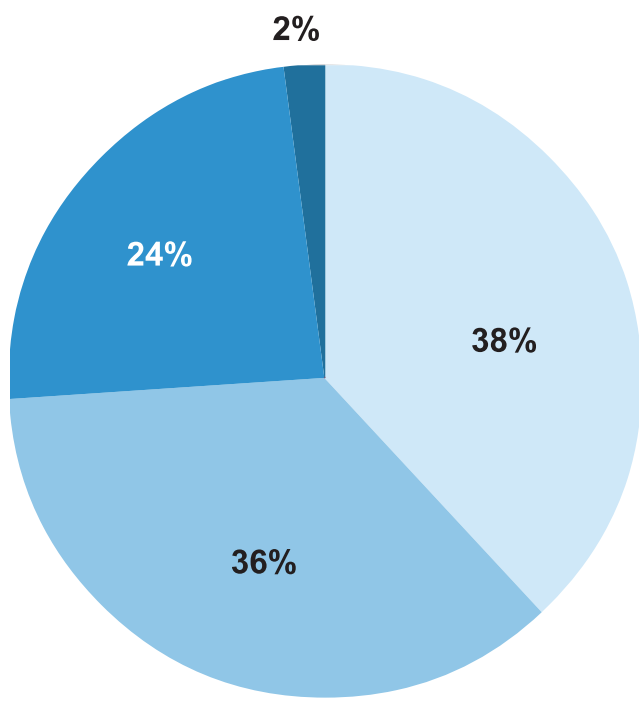

Fully agree

Partly agree

Partly disagree

Fully disagree

Figure 4

However, if we compare this data with the "engagement" rating during the lesson - see Figures 1 and 2, we can conclude that a relatively lower student participation rating does not mean low motivation and engagement in the process. This leads to the conclusion that the active involvement of a relatively smaller student interaction in the process, more passive action - listening, watching, individual ongoing analysis and conclusions - also makes it possible to feel motivated and engaged in the overall learning process. From student comments we can see some students feel the benefits of lecturing, listening directly and watching the views of their classmates. This conclusion allows us to think that the methods collected and proposed in the project are generally motivating and engaging, even if the task does not necessarily involve each student in an active process.

We also asked the following question in the survey: "Please describe in your own words, what you enjoyed most during this lesson?” The students were happy to make their comments. In Figure 5, we can look at the comments that briefly describe the main ideas expressed in the comments: students highly valued collaborative opportunities, sharing ideas and hearing student ideas, encouraging creativity, the possibility of practising setting up, expressing and defending their opinions, the possibility of getting to know the material in an unusual way. 


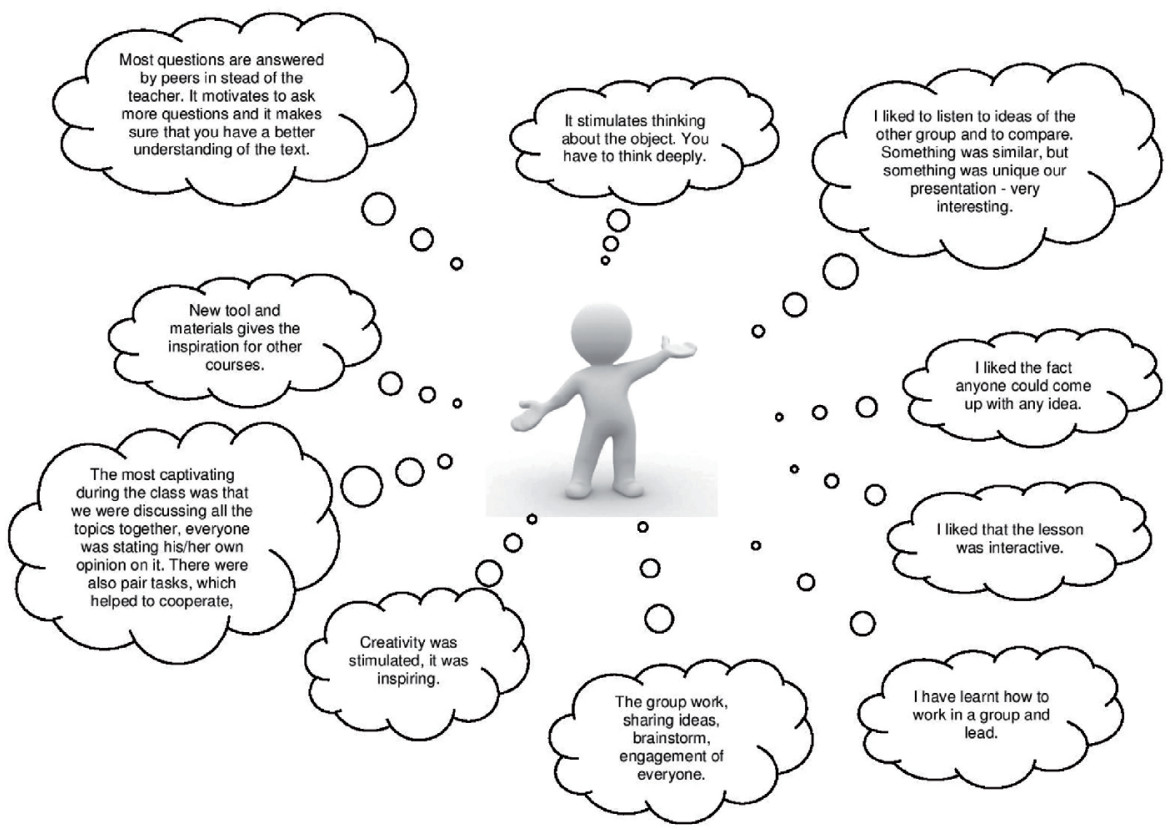

Figure 5

We also asked students to share their thoughts: "Please describe in your own words, what you found most valuable during this lesson." The answers, in part, were in line with answers to the previous question. However, some students distributed the benefits in a particular way. Figure 6 shows examples that reflect the ideas mentioned above. 


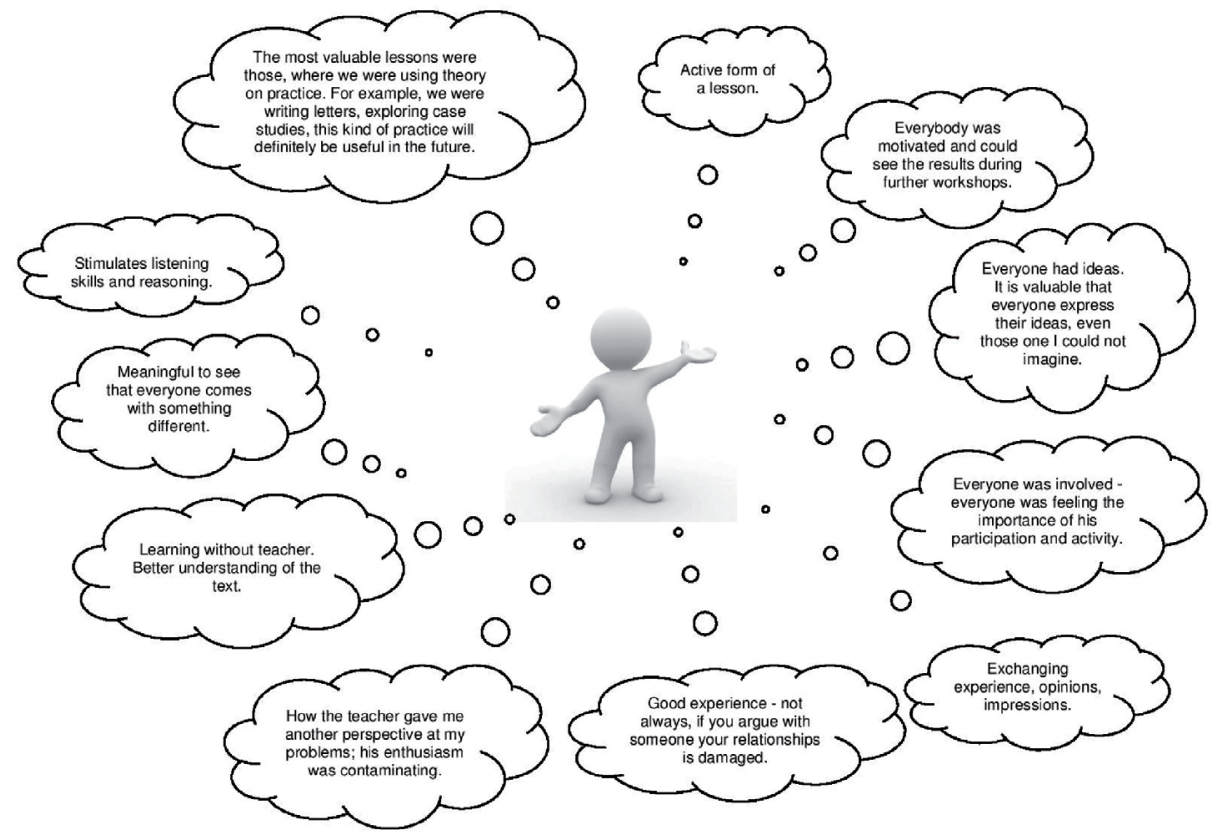

Figure 6

86 academics from Latvia, Belgium and Poland participated in the survey. We asked them to evaluate the same aspects that the students evaluated about the lectures/seminars where some specific method was used.

Almost everybody thought "Students were motivated during the lecture/seminar" - 98.8\% lecturers agree with this statement (see: Figure 7).

$1 \%$

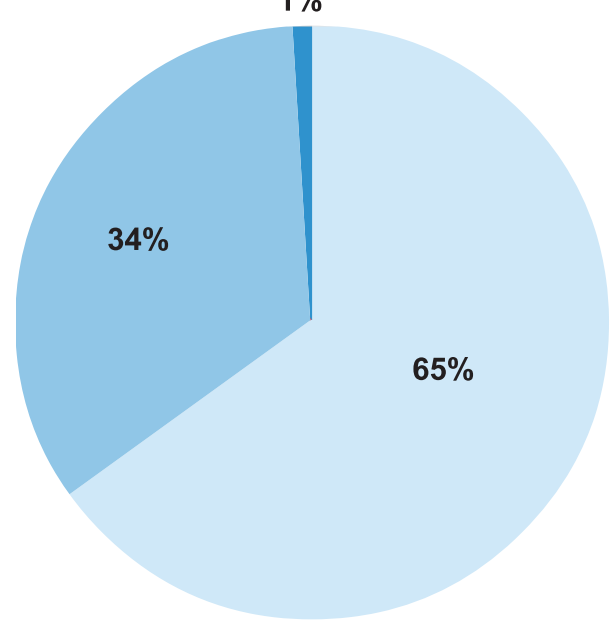

Fully agree

Partly agree

Partly disagree

Figure 7 
Everyone agrees that "Students were engaged in the process during the lecture/ seminar" (see: Figure 8).

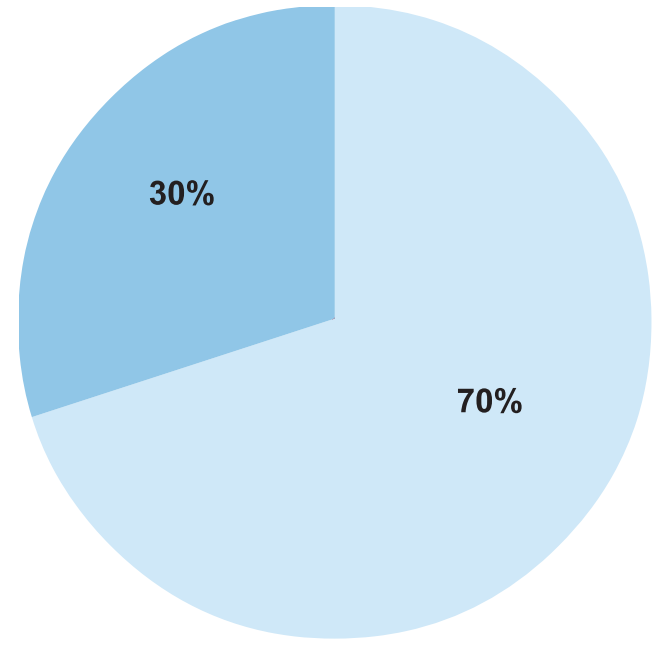

Figure 8
Fully agree

Partly agree

97.6\% of lecturers observed - "Students did understand easily - what should be done during the lecture/seminar" (see: Figure 9).

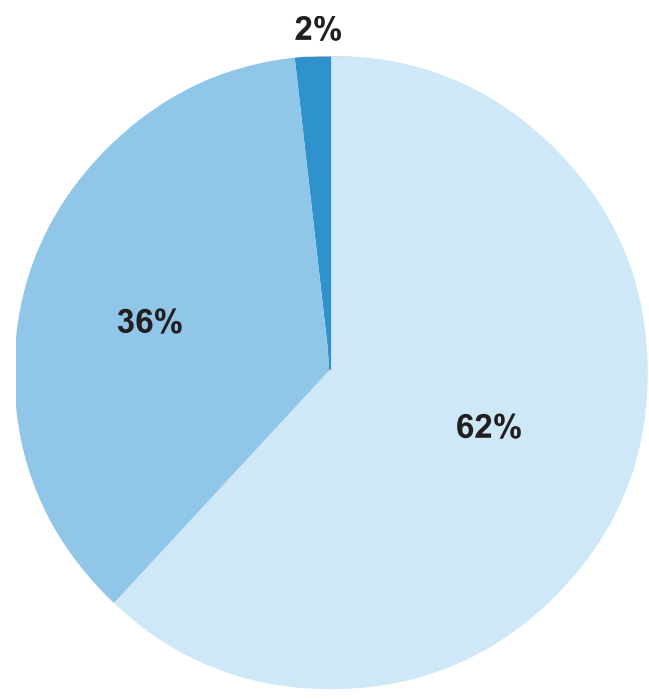

Fully agree

Partly agree

Partly disagree

Figure 9

$94.1 \%$ of lecturers agreed with the statement "Every student was involved in the learning process during the lecture/seminar": 5.3\% partly disagreed (see: Figure 10). 

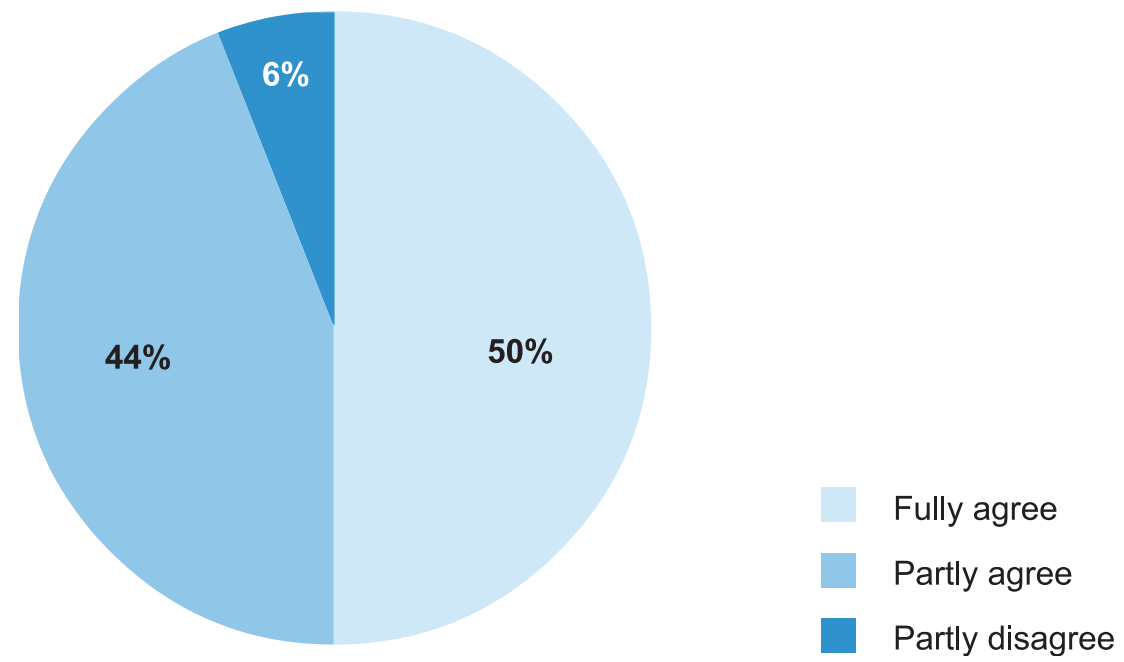

Figure 10

Lecturers admit that it is a challenge to ensure that every student is involved in the learning process. But we can also see that lecturers' answers parallel the answers of students: partial engagement in the learning process does not harm the process of being motivated during the learning process.

All respondents were convinced - they wanted to work again with the tested method (see: Figure 11).

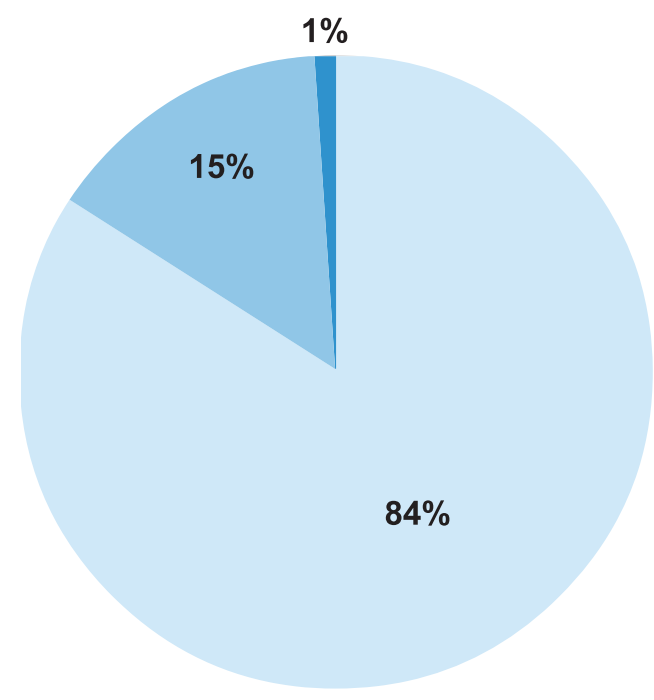

Figure 11

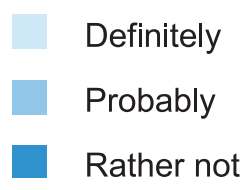


We asked lecturers also to be more specific about their experience and answer the question "What do you find the most valuable about this technique/method/approach? (regarding the used and evaluated method). There are several conclusions:

The methods demand quite extensive preparation from academics. Academics say sometimes it is necessary to use the method more than once to understand the best way to use it and that it is useful to talk to other lecturers about their experience with the method. At the same time, there are methods that are easy to use and simple.

Sometimes lecturers combine several methods or modify them according to the theme or the task of the course. Sometimes the methods are a good way to connect theory with practice. Lecturers admit that most of the methods develop thinking, creativity, communication skills and presentation skills, and teach how to work with information. The methods inspire lecturers to develop a broader skillset of teaching methods, be more creative and to improvise. Some of the students usually don't get involved. Lecturers positively evaluate the use of new technologies and digital tools during the teaching process. Quotes from the questionnaires (see: Figure 12).

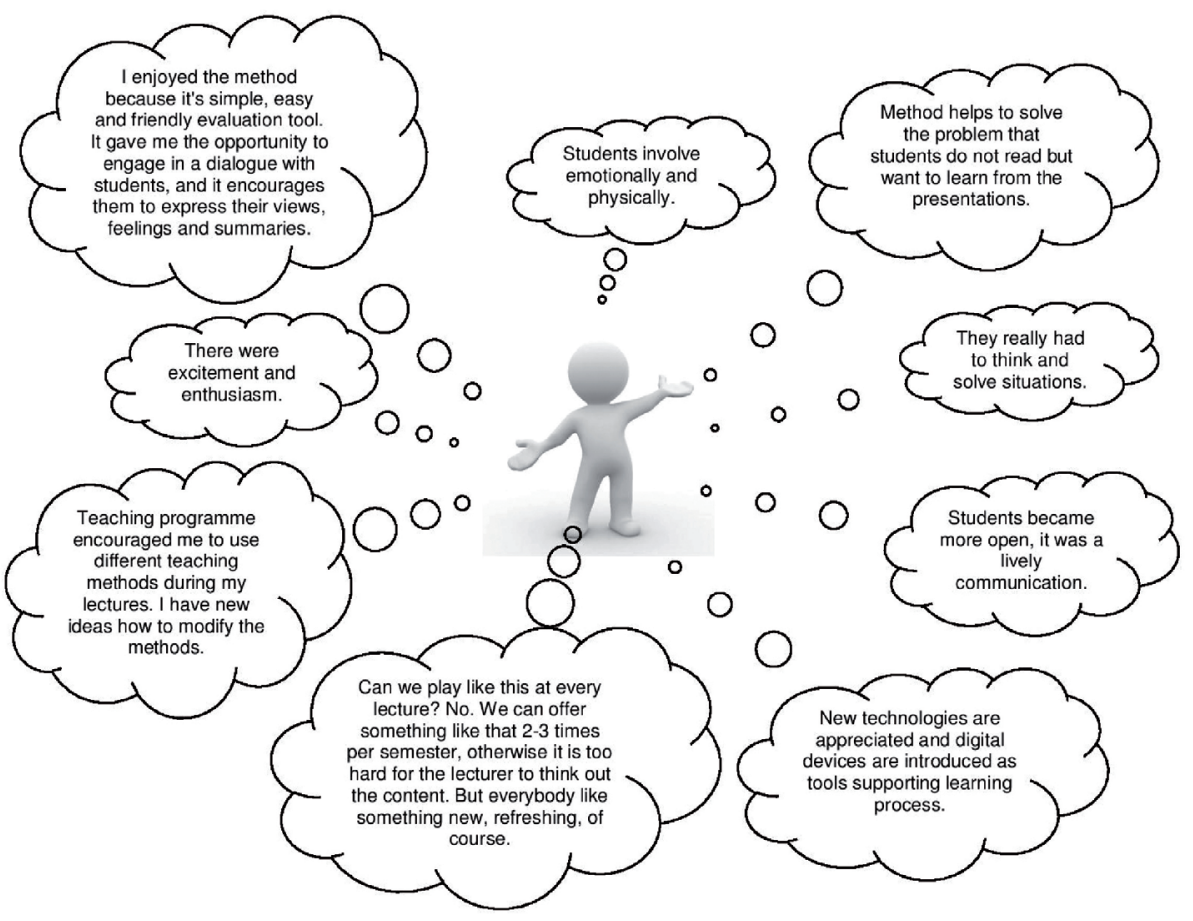

Figure 12 


\section{Evaluation of training programmes}

Within the framework of the project there were training programmes for lecturers in Belgium, Poland and Latvia. Participants tested one or more methods collected in the project - including the training programme's practical task. We are planning to create training programmes as a regular training course offered for lecturers in all three countries.

The main goal of this training programme was to find an opportunity for lecturers to get to know new learning/teaching methods as well as to create a space for discussion about the innovations in learning/teaching and experience exchange.

We evaluated the training programmes and the experience obtained during the training process. The total number of respondents was 37: 9 teachers from Poland, 9 teachers from Belgium and 19 teachers from Latvia.

At first, we invited participants to evaluate the usefulness of this training programme on a scale from 1-10. "10" points means "very useful: much of what I have learned will be useful for further pedagogical work. "1" point means "it was not useful: I will not use anything of what I have learned". The average total score received was 8 . This assessment is considered to be high in order to assess overall the benefits of the programme as a significant benefit for the participants of the programme. We see, however, that there is a possibility to increase this score by enhancing satisfaction with the training programme. Therefore, we clarified the benefits and shortcomings of the programme in order to develop this learning programme in the future.

We asked lecturers about the benefits of the programme: what was your most valuable benefit in this training programme? A large number of lecturers admitted - it was an excellent opportunity to meet colleagues, share teaching/training experiences and to talk about the challenges in the work with students. The training programme gave lecturers an opportunity to talk about the ongoing changes in higher education institutions. Lecturers believe this important discussion is missing from their professional life. It is clear that lecturers also need support and to share experiences: it strengthens the lecturer's confidence as a trainer and opens up possibilities for change and transformation. The programme participants said it was valuable to be aware that other lecturers have similar challenges.

The second largest benefit was the range of methods proposed. It provided new ideas for working with students and new creative ideas for combining and transforming methods.

We asked training programme participants to share missing aspects of the programme: what would you change or add in this training programme? Many lecturers pointed out that they would like to have more workshops. They explained: the programme should be expanded. Lecturers would wish for the possibility to try out more methods together with colleagues during the training process. Several lecturers wished to meet their colleagues to share experience and listen to other colleagues' 
conclusions. Meeting, sharing and discussing with colleagues from other disciplines opens many new perspectives, offers different angles. More meetings are necessary to reach all colleagues and discuss the new possibilities with them.

\section{Bibliography}

Brown T. Change by design, Harper Collins Publishers, HarperBusiness, New York 2009. Cross N., Design Thinking, Berg Publishers, Oxford, New York 2011.

Dewey J. , How we think. Dover Publ. inc., Mineola, New York 1997.

Michalska-Dominiak B., Grocholiński P., Poradnik design thinking, czyli jak wykorzystać myślenie projektowe w biznesie, Helion, Gliwice 2019.

Reidsema C., Kavanagh L., Hadgraft R., \& Smith N., The Flipped Classroom. Practice and Practices in Higher Education, Springer, Singapore 2017.

Robinson K., Out of Our Minds: Learning to be creative, Capstone Publishing Ltd., Oxford 2011.

Szymański M. S., O metodzie projektów, Wydawnictwo Akademickie ŻAK, Warszawa 2010.

http://efe-project.eu/. 
Dariusz Stępkowski* (iD https://orcid.org/0000-0002-6855-1517

Uniwersytet Kardynała Stefana Wyszyńskiego w Warszawie

\section{Recenzja książki: Tomasz Leś, Koncepcje mądrości w filozofii Sokratesa, Platona i Arystotelesa, Wydawnictwo Uniwersytetu Jagiellońskiego, Kraków 2016, 168 ss.}

Myślenie analityczne w Polsce nie jest niczym nowym. Jego początki sięgają okresu międzywojennego, kiedy to grupa filozofów, określanych mianem Szkoły Lwowsko-Warszawskiej, równolegle z kolegami z Oksfordu rozwijała podejście analityczne ${ }^{1}$. Warto dodać, że od pewnego czasu bada się oddziaływanie tej formacji intelektualnej również na rozwój rodzimej pedagogiki². Wciąż jednak do rzadkości należą opracowania stosujące praktycznie metodologię analityczną. Wydaje się, że głównym powodem takiego stanu rzeczy jest to, że w naszym kraju dominuje paradygmat kontynentalny. Ta konstatacja dotyczy zarówno filozofii, jak i pedagogiki. Chociaż w ostatnich dekadach rozpowszechnił się w Polsce termin filozofia edukacji, będący kalką językową angielskiego zwrotu philosophy of education, to jednak niewiele jest prac, w których

* Dariusz Stępkowski - doktor habilitowany, zatrudniony na Uniwersytecie Kardynała Stefana Wyszyńskiego w Warszawie na Wydziale Nauk Pedagogicznych, profesor UKSW. Zainteresowania badawcze: pedagogika ogólna, dydaktyka szkoły wyższej, teoria wychowania moralnego. Wybrane autorskie publikacje książkowe: Pedagogika ogólna i religia (2010) (razem z: D. Benner, A. von Oettingen, Z. Peng), Kształcenie - moralność - demokracja (2015) (razem z K. Maliszewskim i B. Śliwerskim), Istota, sens i uwarunkowania (wy)ksztatcenia (2019).

${ }^{1}$ W. Tatarkiewicz, Historia filozofii. T. 3. Filozofia XIX wieku i współczesna, PWN, Warszawa 1978; A. Nowaczyk, Filozofia analityczna, Wydawnictwo Naukowe PWN, Warszawa 2008; T. Szubka, Filozofia analityczna. Koncepcje, metody, ograniczenia, Wydawnictwo Uniwersytetu Wrocławskiego, Wrocław 2009.

2 Temu problemowi poświęcony został dział Studia i rozprawy w pierwszym numerze „Przeglądu Pedagogicznego" z 2014 roku. Dostępny na: https://repozytorium.ukw.edu.pl/handle/item/1662 [dostęp: 5.06.2019]. 
autorzy relacjonują, jak uprawia się tę filozofię za morzem resp. po drugiej stronie Wielkiej Wody, albo ją współtworzą i doskonalą.

Wymaga szczególnego podkreślenia fakt, że filozofia analityczna posługuje się charakterystyczną metodologią. Bez tej metodologii traci ona właściwie swój sens. W tym kontekście musi budzić zastanowienie stawianie na równi pojęcia filozofia edukacji z takimi pojęciami, jak: filozofia wychowania, pedagogika filozoficzna, filozofia pedagogiczna czy filozofia pedagogiki. Wydaje się, że takie postępowanie jest nie tylko mało zasadne, lecz również mylące, gdyż zakłada wymienność filozofii analitycznej i filozofii kontynentalnej, co jest oczywistym błędem. Być może na trop rozwiązania tego problemu naprowadza ujęcie filozofii edukacji jako jednego z nowoczesnych sposobów uprawiania pedagogiki ogólnej³.

Wskazanego powyżej deficytu opracowań pedagogicznych w języku polskim, w których metodologia analityczna dostarcza instrumentarium badawczego, nie pomniejszają deklaracje autorów „wpisujących” samych siebie w filozofię edukacji bez zachowywania wierności analitycznemu sposobowi myślenia. Moim zdaniem nie dostrzegają oni zasadniczej różnicy między filozofowaniem z perspektywy analitycznej a innymi rodzajami uprawiania namysłu filozoficznego. Pierwsze implikuje posługiwanie się metodami właściwymi anglosaskiej filozofii analitycznej - są to przede wszystkim: klasyczna analiza pojęciowa, analiza logiczna, analiza lingwistyczna i analiza systematyczna ${ }^{4}$. W drugim przypadku mamy nierzadko do czynienia z generowaniem ad hoc zdroworozsądkowych pomysłów, którym przyznaje się moc dostarczania odpowiedzi na współczesne wyzwania edukacji. Tak więc linia demarkacyjna między filozofią edukacji a analityczną filozofią edukacji przebiega przez obszar metodologii, a dokładniej: przez analizę filozoficzną. Tak jak w filozofii analitycznej wymienione powyżej cztery metody stanowią źródło jej siły i zarazem przyczynę słabości, tak samo rzecz się ma z analityczną filozofią edukacji. Do jej najważniejszych ograniczeń można zaliczyć koncentrację uwagi na kwestiach szczegółowych i pewną hermetyczność, która wynika z rygorów metodologicznych. Na temat korzyści chciałbym więcej powiedzieć w nawiązaniu do recenzowanej publikacji.

Książka T. Lesia z wielu powodów zasługuje na baczną uwagę i wnikliwe przestudiowanie. Autor w praktyce zastosował metodologię filozoficzno-analityczną. Posługując się nią, prześledził obecność i sposób odczytywania mądrości w koncepcjach trzech klasyków filozofii starożytnej: Sokratesa, Platona i Arystotelesa. Żeby uzasadnić dokonany przez siebie wybór tych właśnie, a nie innych myślicieli, T. Leś wylicza aż siedem argumentów (s. 10-11). Daremnie próbowano by sprowadzić je do wspólnego mianownika. Ten fakt zapowiada moim zdaniem pierwszą korzyść podejścia analitycznego. Polega ona na uzmysłowieniu, jak bardzo złożone mogą być kwestie logiczno-językowe i ile skrupulatności i dociekliwości ze strony autora wymagało ich

${ }^{3}$ D. Benner, D. Stępkowski, Pedagogika ogólna, [w:] E. Gigilewicz (red.), Encyklopedia katolic$k a$, t. 15, Towarzystwo Naukowe Katolickiego Uniwersytetu Lubelskiego Jana Pawła II, Lublin 2011.

${ }^{4}$ T. Szubka, dz. cyt., s. 88-185. 
rozwikłanie. Nie dziwi więc, że lista problemów do przeanalizowania, którą przedstawia T. Leś na początku swojej pracy, jest jeszcze dłuższa niż wspomniany wykaz argumentów. Obejmuje ona aż jedenaście pól eksploracji (s. 13). Da się je przyporządkować do jednego dążenia autora, którym jest wydobycie z poglądów i teorii wymienionych trzech klasyków starożytności stałych elementów pojęcia mądrości i pełnionej przez nią roli. Elementy te zostały syntetycznie zrekapitulowane i przedyskutowane w czwartym i ostatnim rozdziale (s. 151-160). Pod jego koniec T. Leś nawiązał do problemów pedagogicznych, które powtórnie ujawniły się dzięki jego badaniu. Problemów tych autor nie rozwiązuje, lecz zadaje czytelnikowi jako swoistą pracę domową.

Monografia T. Lesia powstała na podstawie rozprawy doktorskiej, którą obronił autor w Uniwersytecie Jagiellońskim (s. 12). Składa się z czterech rozdziałów, zakończenia i bibliografii. Drobne zastrzeżenie może budzić fakt, że wprowadzenie zostało uznane za pierwszy rozdział i włączone do numeracji. W drugim rozdziale autor opisuje pole problemowe i zdaje sprawę ze stanu badań dotyczących mądrości. Trzeci zawiera wnikliwą analizę koncepcji filozoficznej każdego z wymienionych w tytule myślicieli, a w czwartym - jak już to zasygnalizowano - autor rekapituluje wyniki swoich poszukiwań i odnosi je do problemów i pytań pedagogicznych.

Trudno w szczegółach przedstawić zawartość wszystkich rozdziałów. W związku z tym chciałbym skoncentrować uwagę na schemacie postępowania badawczego, który legł u podstaw analiz przeprowadzonych przez T. Lesia w zasadniczym rozdziale trzecim. Na schemat ten składają się dwa rodzaje czynności: rekonstruowanie i interpretowanie. W postępowaniu rekonstrukcyjnym autor docieka: (1) definicji mądrości każdego z autorów, tj. Sokratesa, Platona i Arystotelesa, (2) założeń filozoficznych, (3) roli mądrości w całokształcie myślenia filozoficznego, (4) relacji mądrości do innych pojęć filozoficznych, (5) dróg osiągania mądrości i (6) perspektywy praktyczno-społecznej implikowanej przez daną koncepcję. Warto podkreślić, że T. Lesia nie zadowalają istniejące przekłady dzieł starożytnych klasyków i dlatego sięga po ich wersje oryginalne, czyli w języku greckim. Współcześnie znajomość greki wśród pedagogów można uznać za ewenement. Na uznanie zasługuje również to, że autor w swoim opracowaniu wykorzystał literaturę anglojęzyczną, przez co umożliwił czytelnikowi zapoznanie się z kwestiami aktualnie dyskutowanymi w filozofii analitycznej.

Drugi rodzaj czynności badawczych - interpretowanie - nie został wyodrębniony w strukturze pracy w samoistnym fragmencie (np. podrozdziale), lecz sekunduje rozważaniom w każdym $\mathrm{z}$ wymienionych powyżej sześciu punktów. W tym miejscu na szczególne podkreślenie zasługują przeprowadzone przez autora analizy logiczne, które oprócz walorów merytorycznych uzmysławiają, jak ważna jest precyzja myślenia przy badaniu problemów pedagogicznych.

Wspomniana powyżej praca domowa, którą T. Leś zostawia czytelnikowi, dotyczy między innymi intelektualizmu etycznego. Do tego pojęcia i związanego z nim problemu nawiązują mniej lub bardziej bezpośrednio autorzy zastanawiający się nad 
różnicą między wychowaniem moralnym a kształceniem etyczno-moralnym ${ }^{5}$. Teza intelektualizmu etycznego głosi, że działanie moralne jest pochodną wiedzy etycznej. Innymi słowy, znajomość tego, czym jest dobro i zło, warunkuje możliwość działania moralnego. Warto przypomnieć, że za pomysłodawców takiego podejścia uważa się Sokratesa i Platona. W tym kontekście T. Leś pisze: „Wystarczy słabsza wersja tego stanowiska (wiedza etyczna jest warunkiem wystarczającym działania etycznego), by odrzucić możliwość, że dana osoba wie, jak działać, a jednocześnie w sytuacji, która tego wymaga, nie podejmuje zgodnego z wiedzą działania. Sytuacja, w której jakaś osoba posiada pełną wiedzę (np. odnoszącą się do spraw etycznych), a jednocześnie nie podejmuje zgodnie $\mathrm{z}$ nią działania, nie jest możliwa na gruncie koncepcji tych dwóch myślicieli” (s. 153).

W powyższych słowach autor przyznaje, że intelektualizm etyczny należy uznać w poglądach Sokratesa i Platona za obligatoryjną przesłankę, zarazem jednak zwraca uwagę na pewien szczegół, który łatwo wymyka się uwadze zwolenników radykalnego rozdzielenia (praktycznego) wychowania moralnego i (teoretycznego) kształcenia etyczno-moralnego. Przywołując na pamięć pojęcie mądrości, T. Leś stwierdza, że: „Zarówno u Sokratesa, Platona, jak i Arystotelesa mamy do czynienia z dwoma warunkami mądrości: wiedzą i działaniem, a różnica polega jedynie na tym, że Arystoteles artykułuje to wprost, w postaci mądrości praktycznej, natomiast jego poprzednicy w sposób pośredni” (s. 153). A zatem wszyscy trzej filozofowie afirmują konieczność dostrzeżenia w działaniu moralnym komponentu intelektualnego - czy to w formie wiedzy boskiej (Sokrates), czy też idei Dobra (Platon), czy w końcu teleologicznego namysłu praktycznego (Arystoteles). Na tej podstawie należy uznać za nadużycie formułowanie wobec kształcenia etyczno-moralnego zarzutu intelektualizmu etycznego za to tylko, że bardziej eksponuje się w nim refleksję etyczną niż kształtowanie charakteru (cnoty) i działania moralnego.

Na zakończenie swoich rozważań T. Leś formułuje pięć wymogów, które jego zdaniem warunkują budowanie praktycznej wiedzy pedagogicznej. Wydaje mi się, że odnoszą się one również do projektowania kształcenia etyczno-moralnego zgodnego z kryterium mądrości. Są to: „[1] wymóg wiedzy naukowej - jako czynnika kształtującego adekwatne przekonania dotyczące rzeczywistości; [2] wiedzy etycznej - jako czynnika kształtującego przekonania i postawy moralne; [3] dialogu - jako warunku osiągania wyższej wymienionych typów wiedzy; [4] kształtowania cnót i charakteru oraz [5] precyzyjnego rozumowania, argumentowania, krytyczności wobec poglądów własnych i innych osób” (s. 162). Stosując ostatni wymóg do siebie samego, autor podkreśla znaczenie w badaniach pedagogicznych (i nie tylko) „skromności poznawczej”

${ }^{5}$ J. Horowski, Rozwój zdolności sądzenia czy rozumowania? Wokół pytania o fundamenty kompetencji etyczno-moralnych, „Forum Pedagogiczne” 2016, nr 2/1, s. 143-149; A. Rajský, What's Wrong in Modern Education? Maritain's Warning is Valid Today More than Ever, "Caritas et Veritas” 2018, No. 8, s. 68-73; W. Starnawski, Primum non nocere... Uwagi na temat uwarunkowań edukacji filozoficznej/moralnej, „Forum Pedagogiczne” 2017, nr 2, s. 189-190. 
(s. 161). Tę skromność da się wyraźnie dostrzec w recenzowanej publikacji. To z kolei pozwala z nadzieją patrzeć na przyszły rozwój analitycznej filozofii edukacji w Polsce.

\section{Bibliografia}

Benner D., Stępkowski D., Pedagogika ogólna, [w:] E. Gigilewicz (red.), Encyklopedia katolicka, t. 15, Towarzystwo Naukowe Katolickiego Uniwersytetu Lubelskiego Jana Pawła II, Lublin 2011.

Horowski J., Rozwój zdolności sądzenia czy rozumowania? Wokół pytania o fundamenty kompetencji etyczno-moralnych, „Forum Pedagogiczne” 2016, nr 2/1.

Nowaczyk A., Filozofia analityczna, Wydawnictwo Naukowe PWN, Warszawa 2008.

Rajský A., What's Wrong in Modern Education? Maritain's Warning is Valid Today More than Ever, „Caritas et Veritas” 2018, No. 8.

Starnawski W., Primum non nocere... Uwagi na temat uwarunkowań edukacji filozoficznej/moralnej, „Forum Pedagogiczne” 2017, nr 2.

Szubka T., Filozofia analityczna. Koncepcje, metody, ograniczenia, Wydawnictwo Uniwersytetu Wrocławskiego, Wrocław 2009.

Tatarkiewicz W., Historia filozofii. T. 3. Filozofia XIX wieku i współczesna, PWN, Warszawa 1978. 


\title{
Kamil Lewandowski*
}

Akademia Humanistyczno-Ekonomiczna w Łodzi

\section{Zajęcia taneczne z młodzieżą z niepełnosprawnością intelektualną jako forma terapii pedagogicznej}

\begin{abstract}
Streszczenie: $\mathrm{W}$ artykule przedstawiam obraz pewnego podejścia do tańca i sposobu jego postrzegania, który może stać się ważnym narzędziem do niesienia pomocy w edukacji. Zawarte tu informacje i wiedza są efektem mojej pracy badawczej na studiach licencjackich, która została zrealizowana w roku akademickim 2017/2018 w Akademii Humanistyczno-Ekonomicznej w Łodzi na kierunku taniec, specjalności pedagogika tańca. Tytuł pracy badawczej to Terapeutyczne funkcje zajęć tanecznych z młodzieżą z niepełnosprawnością intelektualną.
\end{abstract}

Słowa kluczowe: taniec, integracja, wsparcie, niepełnosprawność

\section{Wprowadzenie}

Ruch jest nieodzowną częścią życia każdego człowieka. Źródła historii przemawiają za tym, że najpierw ludzie nauczyli się komunikować za pomocą gestu, potem dopiero dodali do niego słowa. Taniec od zawsze pełnił swoistą funkcję komunikacji. Już plemienni tubylcy mieli swoje tańce. Wyrażali dzięki nim radość, smutek, narodziny dziecka czy przygotowanie do polowań. Współczesna kultura pozbawiona jest tych źródeł, jednoczenia społeczności, wielopokoleniowych tradycji, które znajdowały się w ówczesnych tańcach. W mojej codziennej pracy zawodowej wśród osób z niepełnosprawnościami często wplatam elementy ruchu jako najcenniejsze narzę-

“ Kamil Lewandowski - czynny tancerz tańca etnicznego, afrykańskiego. W kręgu jego zainteresowań są: taniec w edukacji, psychoterapia tańcem i ruchem, taniec ekspresyjny, kontakt z naturą, podróże do źródeł życia. Twórca inicjatywy Taniec WPP - Taniec Wsparciem Procesu Pedagogicznego (2019) oraz założyciel szkoły tańca o takim samym profilu Criss-Cross Taniec i Natura w Łodzi. 
dzie do stymulowania prawidłowego rozwoju. W ruchu zawiera się motywacja, a ona jest źródłem życia każdego człowieka.

Tematem mojej pracy było dotarcie do poznania źródeł na temat terapeutycznych funkcji tańca, które mogą wspomagać rozwój osób z niepełnosprawnością intelektualną oraz pomóc im w utrzymaniu jak najlepszej sprawności organizmu.

Taniec jako rodzaj ruchu uprawiany jest na całym świecie w wielu różnorodnych formach. Można go spotkać na ulicy, w szkole, na scenie, w klubie dyskotekowym. Jest on udziałem młodych i starszych pokoleń.

Taniec jest jedną z najstarszych dziedzin sztuki w działalności kulturowej człowieka. Szerokie zastosowanie tańca, jakie zostało wykorzystane do budowania tożsamości człowieka, ukazywane jest przez wiekowy rozwój cywilizacji, prastarych wierzeń, kontaktu z otaczającym światem, mnogości stylów i technik tanecznych, filozofii, budowania kultury wszelkich narodowości całego świata.

Jest on źródłem wyrazu emocji i przeżywania wrażeń estetycznych, które różnie można odbierać i interpretować. Niełatwo prosto i jednoznacznie go zdefiniować. Ogólnie rzecz biorąc, jest to rytmiczny ruch wykonywany przy muzyce. Ruch i rytm są ściśle ze sobą powiązane. Na rytm życia odpowiada człowiek ruchem. Inspiracje tańca daje przyroda, zwierzęta - chód, bieg, skakanie. A rytm to wszystko, co nas otacza, pory roku, kołysanie drzew na wietrze, bicie serca, oddychanie. Ruch wykonywany przez człowieka jest zależny od jego osobistych możliwości. Jest związany i uzależniony od trybu jego życia. Taniec zawiera w sobie większą tajemnicę, która jest odkrywana wraz z czasem jego doświadczania i przeżywania. Pierwszą znaną nam ze źródeł definicją tańca jest ta zaproponowana przez Rzymianina Lukiana z Samosate, który pisał: „Taniec polega na wiernym wyrażaniu przeżyć duchowych i zjawił się równocześnie z powstaniem wszechświata, a jego źródłem jest odwieczna miłość”. Inna ze znalezionych definicji mówi, że taniec jest jak ulotny środek ekspresji. Jest realizowany w określonym stylu i formie, które przedstawia ludzkie ciało poruszające się w przestrzeni. Idąc dalej, według Małej encyklopedii muzyki taniec jest zespołem zjawisk ruchowych, transformacją naturalnych ruchów ciała, które powstają pod wpływem wypływających bodźców emocjonalnych, skoordynowanych z muzyką ${ }^{2}$. W ten sposób może kształtować się pewne wyobrażenie o tańcu, który należy do czegoś intymnego, osobistego. Nie jest jednak prawdą, że to jego jedyna właściwa wizja.

M. Wiszniewski w książce Taniec jako terapia przedstawia zbiór wiedzy, który pozwolił mu na wydanie pracy. Istotne dla moich badań jest w niej przedstawienie teorii tańca terapeutycznego, która opisuje jego podstawowe i najważniejsze założenia. Jak pisze autor, istnieje wiele idei i kierunków spojrzenia na taniec terapeutyczny. Jedne nawiązują do psychoterapii, psychologii, inne do pracy z ciałem, fizykoterapii, sztuki

${ }^{1}$ O. Kuźmińska, Taniec $w$ teorii i praktyce, AWF, Poznań 2002, s. 25.

2 S. Śledziński, Mała encyklopedia muzyki, Polskie Wydawnictwo Muzyczne, Warszawa 1981, s. 346 . 
performance, tańców etnicznych, teatru, rytuału, praktyk szamańskich, doświadczeń duchowych. Podstawą rozumienia tańca terapeutycznego jest realizacja ruchu, która wpływa na ciało i umysł. A więc to, co robimy z ciałem, ma wpływ na nasze myślenie, a to, co robimy z naszym umysłem, jest uwidocznione w ciele. Taniec może wpływać na zdrowie naszego ciała, stan umysłu, ale jednocześnie zmieniać nasze emocje oraz samopoczucie.

M. Wiszniewski wymienia następujące korzyści tej formy ruchu:

- rozładowanie nadmiaru energii oraz odprężenie psychiczne,

- poprawa relacji z ludźmi,

- rozwój świadomości ciała,

- rozwój inteligencji emocjonalnej,

- poprawa ogólnej sprawności organizmu,

- pobudzanie organizmu do wydzielania endorfin, tzw. hormonów szczęścia,

- lepsza kondycja fizyczna i koordynacja wzrokowo-ruchowa,

- rozwój kreatywności,

- rozwój umiejętności wyrażania siebie ${ }^{3}$.

Taniec terapeutyczny jest powrotem do starożytnych korzeni tańca. W tym tańcu są zawarte te same idee, jakie towarzyszyły człowiekowi sprzed tysięcy lat. Taniec postrzegano jako formę terapii, uzdrawiania i rozwoju osobistego. Tradycja ta zaginęła w Europie i zachodnim kręgu kulturowym na wiele stuleci. Powrót do tych zapomnianych znaczeń tańca odkrywa przed nami nadzieje na wspieranie rozwoju człowieka i społeczeństwa.

Poszukując niezmiennie użyteczności tańca dla społeczeństwa i edukacji, pragnę przytoczyć pojęcie terapii z Encyklopedii pedagogicznej XXI wieku. Terapia zajmuje się organizowaniem oraz wspomaganiem wychowanka w jego wychowaniu, redukowaniu zaburzeń rozwoju czy zaburzeń zachowania za pomocą wszystkich dostępnych metod i środków pedagogicznych. Istotą tej pracy jest takie organizowanie czasu, by przez wyzwalanie pozytywnych zmian motywujących go do działania usprawniał zaburzony proces, nietypowe zachowania, kompensował braki poszczególnych swoich funkcji. Ważna w sposobie tej terapii jest współpraca podopiecznego z osobą prowadzącą zajęcia ${ }^{4}$. Terapia pedagogiczna, o której mowa w tytule pracy, pojawiła się w pedagogice specjalnej i określona została mianem pedagogiki dopiero w XX wieku ${ }^{5}$. Jej użyteczność jest rozumiana przeze mnie jako wsparcie całości procesu wychowania i holistyczny sposób niesienia pomocy osobom z niepełnosprawnościami.

${ }^{3}$ M. Wiszniewski, Taniec jako terapia, Zacharek Dom Wydawniczy, Białystok 2016, s. 17.

${ }^{4}$ T. Pilch, Encyklopedia pedagogiczna XXI wieku, t. IV, „Żak”, Warszawa 2007, s. 645.

${ }_{5}^{5}$ M. Wolska-Długosz, [w:] T. Pilch (red.), Encyklopedia pedagogiczna XXI wieku, t. VI, „Żak”, Warszawa 2007, s. 648. 


\section{Taniec w obliczu edukacji}

Znany specjalista doktor psychologii, psychoterapeuta terapii behawioralnej Detlef Kappert w książce Tańcząc $z$ dziećmi podkreśla znaczenie sztuki w wychowaniu dzieci. „Wydaje się, że dzieciom potrzeba granic, ale nie ograniczeń i zakazów, lecz przejrzystości świata materialnego oraz pobudzenia ich wyobraźni przez innych ludzi w zabawie i codziennym tworzeniu"6. Autor ten szczególnie podkreśla znaczenie tańca jako formy sztuki w wychowaniu. Jego zdaniem taniec stanowi naturalne uspołecznienie $\mathrm{w}$ grupie. Jest skutecznym środkiem zapobiegającym alienacji dzieci, które z różnych powodów mogą być wyłączone z grupy.

Według mnie Detlef Kappert w swojej książce bardzo dobrze przedstawia potrzeby edukacji dzieci z niepełnosprawnościami. W otaczającym świecie często konfrontują się one z brakiem akceptacji społecznej, trudnościami w nawiązywaniu relacji czy dużym napięciem psychicznym związanym ze swoim upośledzeniem umysłowym, ruchowym oraz innymi ograniczeniami. Autor przekonuje nas do opinii, że każdy człowiek zasługuje na szacunek. „Przy odrobinie szacunku nawet «dziwny» może swoją osobą wzbogacić społeczeństwo", pisze Detlef Kappert. Każdy człowiek bowiem - mniej czy bardziej uzdolniony - potrzebuje kontaktu z ekspresją fizyczną, szaleństwem, innymi ludźmi, zwierzętami i prostymi formami twórczości codziennej. Taniec kształtuje za pomocą ruchu społeczne zachowania. Uczenie się w ten sposób sprawia przyjemność, bezstresowo poprawiając umiejętności motoryczne i wywołując wewnętrzną motywację. Fizyczne uczenie się poprawia samoocenę i ocenę swojej sytuacji. Poprzez zabawę dzieci mają możliwość w bezpieczny sposób uczyć się zróżnicowanego postrzegania i nieagresywnego działania. Kappert pisze również, że taniec jest kształceniem estetycznym poprzez ciało jako doświadczenie natury w człowieku. Może zrelatywizować największe zaniedbania wychowawcze. Autor tłumaczy to tym, że taniec jest spotkaniem z samym sobą. Gdy poruszamy się we wspólnym rytmie, maleją wszelkie bariery. Ten rytm, chociaż tańczymy oddzielnie, łączy. Stąd stwierdzam jednoznacznie, że ruch w edukacji może zajmować ważne miejsce jako pomoc w holistycznym zrozumieniu niesienia pomocy dzieciom i młodzieży biorącym udział w zajęciach tanecznych.

\section{No ale jak się to tańczy?}

Kluczowym i ważnym elementem jest fakt, że każdy odpowiednio przygotowany taniec może mieć zalety wspomagające rozwój osoby z niepełnosprawnością intelektualną. Prowadzenie zajęć dla takich uczniów wymaga jednak dostosowania swoich umiejętności i potrzeb do możliwości poznawczych oraz umiejętności tanecznych swoich podopiecznych. Często zdarza się nam, że chcemy, aby coś było jakieś określo-

\footnotetext{
${ }^{6}$ D. Kappert, Tańczący z dziećmi, Kined - Joanna Zwoleńska, Warszawa 2005, s. 14.
} 
ne, utrzymywało nasze standardy i spełniało nasze oczekiwania. Dana technika tańca wymaga od nas odpowiedniej postawy, charakterystyki ruchu, jej jakości i wyglądu. W przypadku pracy z osobami z pewnymi trudnościami możemy napotkać problemy, co może wprowadzać nas w pewnego rodzaju frustrację, wywoływać niezrozumienie i brak akceptacji tego, co widzimy. Jednak w pracy z tymi osobami ruch nie opiera się na technice figur tanecznych czy możliwościach akrobatycznych. Piękno w tym przypadku jawi się jako ruch sam w sobie, determinacja tańczącego, zabawa, swoboda i wolność. Taniec pozwala tym osobom na spontaniczne wyrażanie siebie, jakby zabierając ich troski na ten czas. Taki taniec pozwala zapomnieć choć na chwilę o swoich ograniczeniach i dyskomforcie.

\section{Wnioski}

Z otrzymanych wyników badań przeprowadzonych na grupie 16 respondentów (uczniów, z którymi mam przyjemność pracować), ankiet dla grupy 16 rodziców oraz 20 nauczycieli pracujących z tymi osobami wyłoniło się pięć najchętniej wybieranych funkcji tańca. Są to:

- poprawa koordynacji wzrokowo-ruchowej,

- sprawianie radości,

- wyzwalanie emocji,

- uczenie zasad współpracy i wzajemnego szacunku,

- poprawianie komunikacji wśród dzieci i relacji społecznych z rówieśnikami.

Z badań wynika, że dzieci, które chodziły na cykl zajęć tanecznych, bardzo je lubiły. To ważny wniosek z punktu widzenia pedagoga i rozwoju struktury działań w szkole. W ten sposób otwieramy dziecko na nowe doświadczenie. Jest nim kontakt w dużej grupie rówieśniczej, który nie jest możliwy na codziennej lekcji w trakcie szkolnych zajęć. Poza tym dziecko pełne pasji jest chętniejsze, by dzielić się swoimi przeżyciami. To wspaniały pretekst do budowania z nim relacji. Ciekawym przykładem mogą stać się również opinie nauczycieli na temat zajęć tanecznych.

Bardzo ciekawym przykładem są opinie nauczycieli na temat zajęć tanecznych:

Bo to coś innego, coś dla nich i przy okazji mogą się zintegrować.

Są radosne w czasie tańca, spontaniczne. Taniec redukuje napięcia w ciele dzie-

ci, pomaga pokazać emocje.

Chętnie biorą udział w zajęciach.

Lubią słuchać muzyki i tańczyć.

Ponieważ taniec sprawia dzieciom przyjemność i wyzwala emocje.

W dniu zajęć mówią o nich od rana. Później opowiadają o nich w domu rodzicom.

Sprawiają radość i pozwalają rozwijać swój talent. 
Integracja z rówieśnikami, wyciszenie trudnych zachowań, poprawa kondycji, ruch pomaga w dotlenianiu komórek, taniec daje im łatwość nawiązywania komunikacji z innymi.

Zajęcia taneczne sprawiają dzieciom wiele radości, widać to w zachowaniu dzieci. Są wesołe, uśmiechnięte, chętnie też opowiadają o takich zajęciach, czekają z utęsknieniem na nie.

Dzieci chętnie brały udział w zajęciach tanecznych i aktywnie w nich uczestniczyły.

Taniec jest najczęściej wymienianą przez dzieci formą spędzania czasu.

W opiniach badanych rodziców powtarza się zdanie, że większość z nich lubi tańczyć. Wśród nich znalazło się siedmioro, którzy prowadzają swoje dzieci na dodatkowe zajęcia taneczne.

Podczas przygotowywania zajęć i programu tańców nadających się dla młodzieży z niepełnosprawnością intelektualną tak zorganizowałem zajęcia, by zespół ruchów, choreografii, tańców wyzwalał w uczestnikach pewną ramę i dyscyplinę, a jednocześnie pozwalał na swobodę wykonywania ruchów po swojemu. Chodziło o to, by czuli, że poruszają się ze wszystkimi i całkiem dobrze im to wychodzi. Ograniczeniem zajęć tanecznych nie była niepełnosprawność intelektualna, a podejście do zorganizowania zajęć i przygotowania takiej przestrzeni, by uczniowie mogli wyrażać siebie i swoje zdolności. W badaniu nauczyciele jednoznacznie twierdzili, że zajęcia taneczne mogą skutecznie wspomagać proces terapii pedagogicznej młodzieży z niepełnosprawnością intelektualną.

Taniec ze względu na swą specyfikę, której istotę stanowi spontaniczne powiązanie ruchów ciała z towarzyszącą muzyką, może stworzyć naturalną sytuację terapeutyczną. Należy dać szansę tańczenia każdemu, kto choćby chce przebywać w tej przestrzeni. Nie raz widziałem, jak dzieci, młodzież, a nawet dorośli, którzy na pozór nie byli zainteresowani ruchem, tańczyli ze wszystkimi. Jedną z pozytywnych obserwacji podczas zajęć tanecznych było dwukrotne przyłączenie się uczestników do grupy tańczących - najpierw jedna z uczennic dołączyła do wspólnego ruchu niezależnie od swoich nawyków. Druga sytuacja dotyczyła ucznia, który w jednym z tańców pozwolił na chwilę zniknąć głębokiemu napięciu w swoim ciele, czego nie sposób było zaobserwować u niego od co najmniej sześciu lat, odkąd go widywałem. Uczestnik ten został wzmocniony pozytywnie przez grupę wielkimi oklaskami.

\section{Podsumowanie}

Obserwując osoby z niepełnosprawnościami na dyskotekach, występach, we wspólnej zabawie ruchowej, gdzie to uczniowie są prowokatorami ruchu, odkrywałem piękne talenty taneczne. Były nimi takie umiejętności jak kręcenie mini swipe znanego $\mathrm{z}$ break dancingu, stanie na rękach, twerking, którego nie powstydziliby 
się w Brazylii, kobiecość, jaką potrafiły ukazywać niektóre dziewczyny w miękkości i swobodzie ruchu. Nie przeszkadzały im w tym trudności liczenia w zakresie do 10 czy zaburzenia mowy. Te osoby nie odczuwały w tańcu swojej „inności”, która często jest nieadekwatnie podkreślana przez rówieśników bez niepełnosprawności intelektualnych. W tańcu ta młodzież mogła wydobyć i uwolnić swoje emocje. Taniec wyzwalał w nich endorfiny i wywoływał uśmiech na twarzach. Uważam, że dużą frekwencję na zajęciach zawdzięczam również tworzeniu atmosfery zabawy, nazywaniu moich podopiecznych tancerzami, używaniu tanecznych sloganów, eksponowaniu zalet młodzieży - to wszystko wpływało na ich poczucie wartości i naturalnej radości.

Moje badania ujawniły, że zajęcia taneczne z młodzieżą z niepełnosprawnością intelektualną przyczyniły się do poprawy ich relacji społecznych z rówieśnikami. Przełamywały izolację tych dzieci. Dzięki tańcowi dzieci częściej komunikowały się ze sobą, czuły się wolne, nieograniczone przez nakazy i zakazy. W tańcu realizowały swoje podstawowe potrzeby bycia w jedności z grupą, bycia razem. Czasami ich sposób nawiązywania relacji w spontanicznym tańcu mógł wydawać się niezrozumiały (podskoki, wydawane dźwięki, ganianie się). Dla nas takie zachowania mogły być nieakceptowalnymi wygłupami, uznawanymi za niepotrzebne, nieadekwatne, niepoprawne. Zastanawiamy się, czy tak powinno się robić, czy to dobrze. Jaką wartość ma jednak w tym przypadku zakazywanie, jeśli nie dajemy nic w zamian?

Zajęcia taneczne sprzyjały również uczeniu norm społeczno-moralnych, dyscypliny i poszanowania zasad współżycia w grupie. Wydobywanie tego potencjału, którym się zajmowałem, nie było realizowane poprzez agresję i wymuszanie danych zachowań. Autorytet i zaufanie tworzy się przez szacunek do drugiego człowieka takim, jaki jest, oraz poprzez budowaną z nim relację. Na zajęciach obserwowałem przejawy empatii uczestników zajęć względem siebie.

$\mathrm{Na}$ koniec dodam, że w zajęciach tanecznych dla młodzieży z niepełnosprawnością intelektualną odkrywam siłę prostoty. Przedstawienie tematu wprowadzającego, opartego na wyobrażeniach i skojarzeniach z otaczającego świata pozwalało młodzieży łatwiej przyswajać ruchy, budziło zainteresowanie daną postacią (np. niedźwiedź), jeśli można go jakoś określić (jest głodny), tańczy (podskoki, żeby zrzucić ul z drzewa), coś symbolizuje (je miód), pozwalało na dużo większe zaangażowanie, swobodę i dobrą zabawę w tańcu. Pracując z badaną młodzieżą, starałem się dostosowywać muzykę do wieku i potrzeb uczestników. To dlatego tańczyliśmy tańce rycerskie, poloneza, poruszaliśmy się do muzyki zespołów Pectus, Brathanki, November project piosenki Bybyć, wykonywaliśmy choreografię do There’s Nothing Holdin Me Back Shawn Mendes. Bardzo ważna w pracy terapeutycznej z młodzieżą jest znajomość nie tylko jej ograniczeń, ale również możliwości.

Moje badania upoważniają mnie do sformułowania wniosku, że taniec stanowi uniwersalną formę zajęć w terapii pedagogicznej, która stymuluje i aktywizuje rozwój fizyczny, psychiczny i społeczny młodzieży z niepełnosprawnością intelektualną. 
Stąd ostatecznie wynika potwierdzenie założonych hipotez badawczych:

Zajęcia taneczne z młodzieżą z niepełnosprawnością intelektualną przyczyniają się do poprawy ogólnej sprawności fizycznej, koordynacji wzrokowo-ruchowej, do lepszego funkcjonowania psychicznego, komunikacji z rówieśnikami, akceptacji siebie i otaczających ludzi.

Zajęcia taneczne z młodzieżą z niepełnosprawnością intelektualną mogą być ważną częścią całości wychowania, którym objęta jest młodzież z niepełnosprawnością intelektualną.

\section{Bibliografia}

Kappert D., Tańczacy z dziećmi, Kined - Joanna Zwoleńska, Warszawa 2005.

Konieczna E.J., Arteterapia w teorii i praktyce, Impuls, Kraków 2003.

Kuźmińska O., Piękno ruchu taneczno-gimnastycznego, Sens, Poznań 1996.

Kuźmińska O., Taniec $w$ teorii i praktyce, AWF, Poznań 2002.

Leszczyńska-Rejczert A., Terapia zajęciowa, [w:] T. Pilch (red.), Encyklopedia pedagogiczna XXI wieku, t. VI, „Żak”, Warszawa 2007.

Okoń W., Nowy słownik pedagogiczny, „Żak”, Warszawa 1975.

Pilch T. (red.), Encyklopedia pedagogiczna XXI wieku, t. IV, „Żak”, Warszawa 2007.

Sękowska Z., Wprowadzenie do pedagogiki specjalnej, Wydawnictwo Akademii Pedagogiki Specjalnej im. Marii Grzegorzewskiej, Warszawa 1998.

Śledziński S. (red.), Mała encyklopedia muzyki, Polskie Wydawnictwo Muzyczne, Warszawa 1981.

Turska I., Krótki zarys historii tańca i baletu, Polskie Wydawnictwo Muzyczne, Kraków 2002.

Wiszniewski M., Taniec jako terapia, Zacharek Dom Wydawniczy, Białystok 2016.

Wolska-Długosz M., [w:] T. Pilch (red.), Encyklopedia pedagogiczna XXI wieku, t. VI, „Żak”, Warszawa 2007.

\section{Dance classes with teenagers with intellectual disabilities as a form of pedagogical therapyy}

Abstract: In this article I discuss the use of dance as a tool for helping in education. The information contained in this study is derived from my undergraduate research, which was carried out in the 2017/2018 academic year at the university of the Academy of Humanities and Economic in Łódź, Department: Dance, Specialty: Dance Pedagogy. The title of the research work is "Therapeutic functions of dance classes with youth with intellectual disabilities."

Keywords: dance, integration, support, disability 
About the author: Kamil Lewandowski - a dancer of ethnic and African dance. His interests include dance and education, dance and movement psychotherapy, expressive dance, contact with nature, travels to the sources of life. He is the creator of the "Taniec WPP" initiative - Dance Support for the Pedagogical Process (2019), and the founder of a dance school with the same profile "Criss-Cross Taniec i Natura" in Łódź. 
Obszar zainteresowań czasopisma naukowego „Kultura i Wychowanie” z założenia ma szeroki zakres. Odwołuje się do zagadnień związanych z interdyscyplinarną relacją kultury i wychowania.

Prezentowane wyniki badań naukowych, głównie z obszaru pedagogiki, ujmowane są w dwa bloki tematyczne rozpraw: filozoficzno-historyczne oraz teoretyczno-empiryczne.

Wersja internetowa, będąca podstawową formą publikacji, dostępna pozostaje na stronie: www.pedagogika.pl

Zespół redakcyjny 